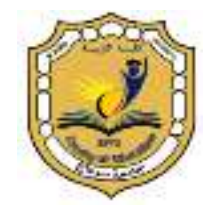

كلية التربية

المجلة التريوية

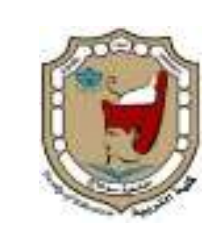

جامعة سوهاج

توظيف هراسي التعلم الالكتزوني في تدريس هقرر تقييم

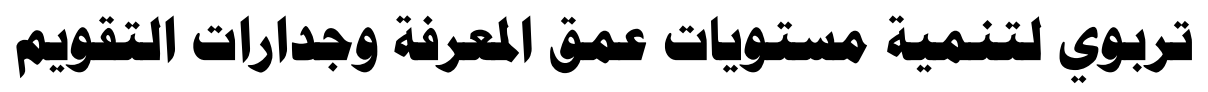
وتوكيد الذات المهنية لاطالب المعلم بكلية الاقتصاد المنزلي

\title{
إعداد
}

د/ شيماء بهيج محمود متولي أستاذ مناهج وطرق التدريس المساعد أستاذ مناهج وطرق التدريس المساعد قسم الاقتصاد المنزبي التربوي كلية الاقتصاد المنزلي - جامعة حلوان كلية الاقتصاد المنزلي - جامعة حلوان

$$
\text { تاريخ الاستلام : lY سبتمبر •Y.rم }
$$

DOI: 10.12816/EDUSOHAG.2021. 135541 


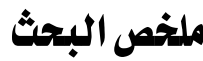

هدف البحث الحالي التعرف على أثر توظيف مراسي التطلم الاكتروني في تدريس مقرر تقييم تربوي لتتمية مستويات عمق المعرفة وجدرات التقويم وتوكيد الذات المهنية لاي

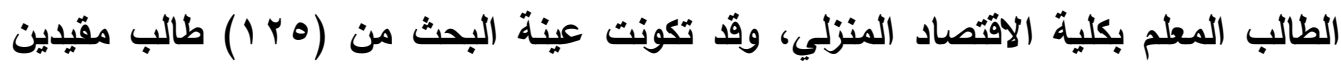
بالفرقة الرابعة بكلية الاقتصاد المنزلي، واعتمد البحث على التصميم شبه التجريبى لمجموعة التهائ

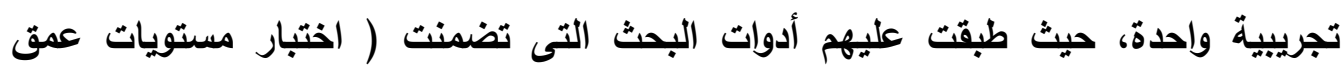
المعرفة ، بطاقة ملاحظة جدرات التقويم ، مقياس توكيد الذات المهنية) قبل ويعد تطبيق التبن

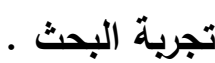

وتوصلت النتائج إلي وجود فرق دال إحصائياً عند بين متوسطات درجات الطلاب

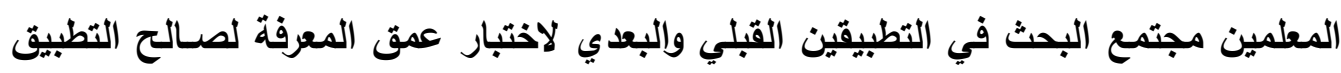

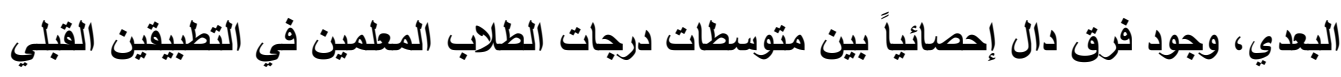

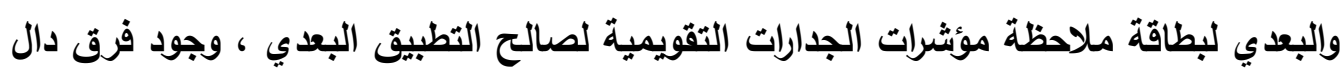

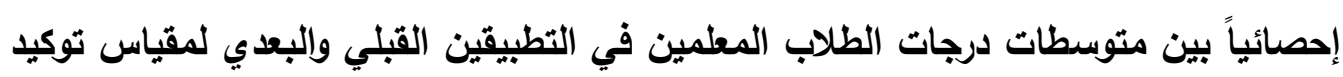

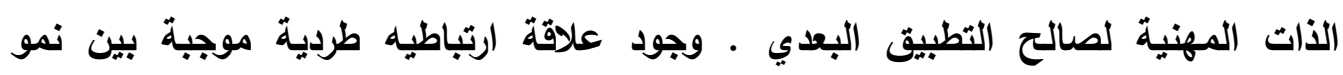

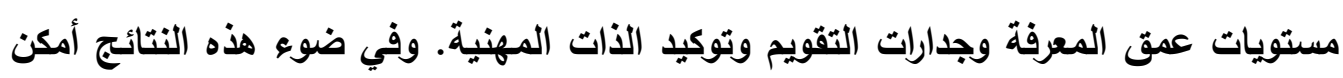

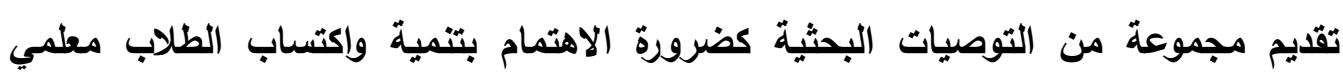

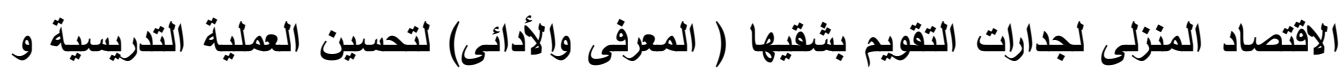

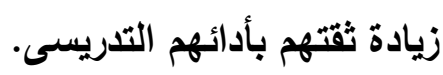
الكلمات المفتاحية: مراسي التعلم الاكتروني ، مستويات عمق المعرفة ، جدرات التقويم ،

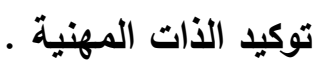


Employing E-learning Anchors in Teaching The pedagogical Assessment Course to Develop Levels of Depth of Knowledge, Competencies Evaluation and Professional Self-affirmation the Student Teacher in the Faculty of Home Economics

The current research aims to know the impact of employing E-learning anchors in teaching an educational assessment course to develop the levels of depth of knowledge, competencies evaluation and professional self-affirmation of the student teacher in the faculty of Home Economics, The research sample consisted of (125) student enrolled in the 4th Division of the faculty of Home Economics, The research relied on the semi-experimental design of one experimental group, Research tools, which included testing depth levels of knowledge, a competencies evaluation note card, a measure of professional self-affirmation, were then applied to them before and after applying the search experience.

The results found a statistically difference between the average grades of students teachers sample research in tribal and dimensional applications to test the depth of knowledge in favor of the remote application, There are significant differences between the averages of the grades of teacher students in the tribal and dimension applications of the note card for competencies evaluation wall indicators, There are significant differences between the averages of the grades of teachers students in the tribal and dimensional applications of the occupational self-assurance measure in favor of the remote application, A proportional positive correlation between the growth of knowledge depth levels, calendar and professional self-affirmation.

A series of research recommendations have been made, such as the need to pay attention to the development of and acquisition of teachers students of home economics for the merits of the competencies evaluation in both( cognitive and performance) to improve the teaching process and increase their confidence in their teaching performance.

Keywords: E-learning anchors, Depth levels of knowledge, Competencies Evaluation, Professional Self-affirmation. 
تؤمن المجتمعات المتقدمة بأن المعلمين الأكفاء الفاعلين هم الركيزة الأساسية

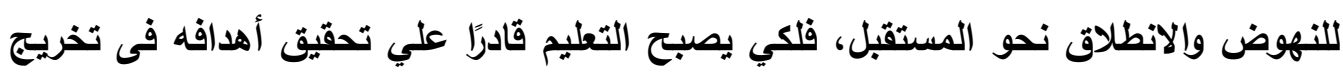

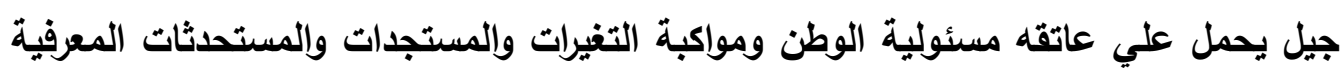

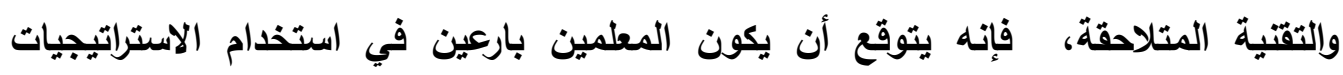

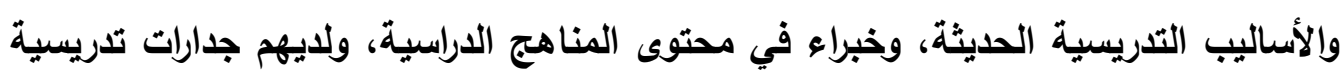

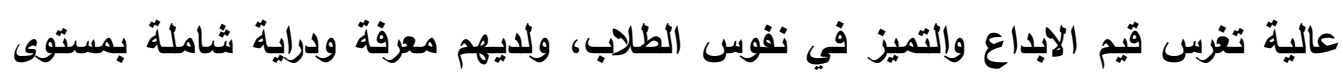

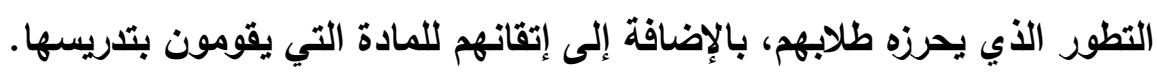

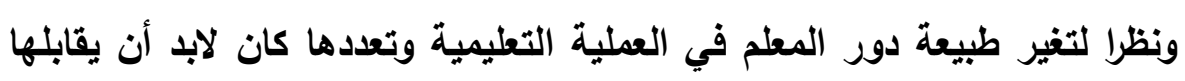

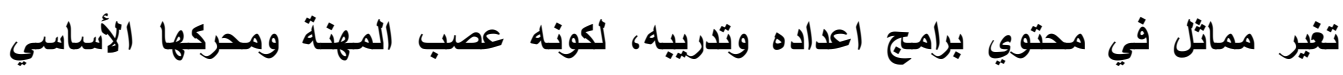

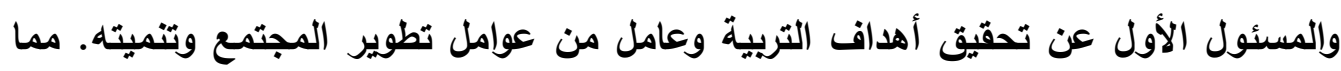

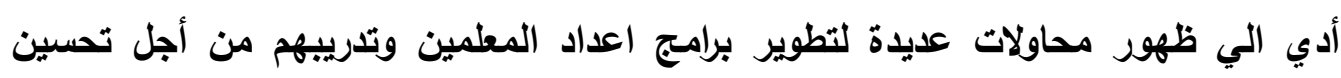

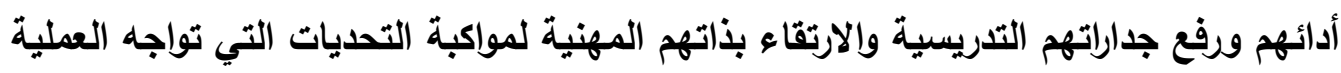

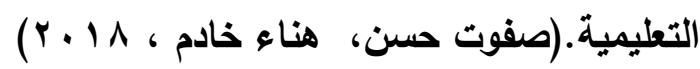
إذ تعد برامج إعداد الطالب المطلم وتطوير كفاياته ومهاراته من القضايا التريوية التي

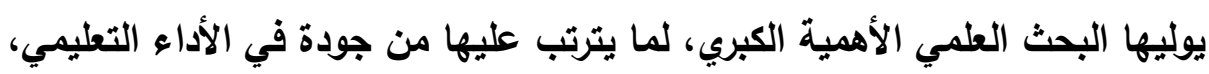

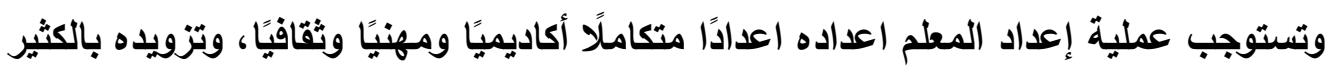

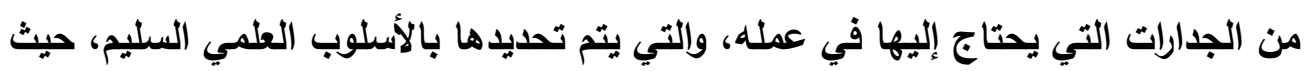

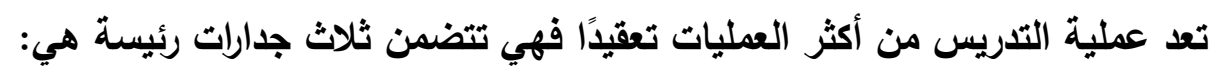

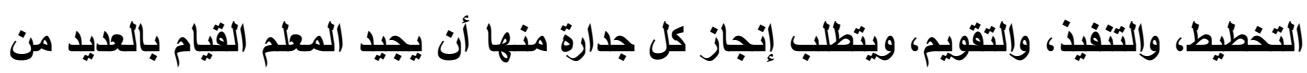

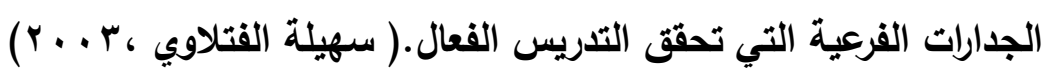

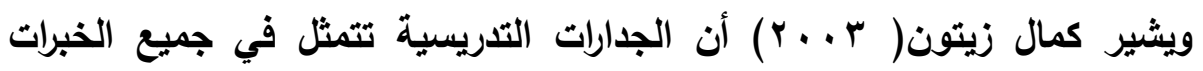
والمعارف التي تنعكس على سلوك المعلم، وتظهر في أنماط وتصرفات مهنية خلال الدور الذي يمارسه عند تفاعله مع جميع عناصر الموقف التعليمي. ومن أهم هذه الأدوار قيامه

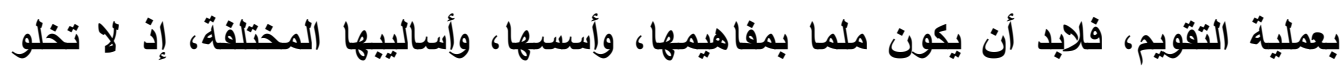


قائمة من قوائم الجدارات التدريسية المطلوية للمعلم في أي مرحلة تعليمية من الجدارات الخاصة بالتقويم، فالتدريس الجيد لأي معلم يتطلب تقويما شاملا لجوانب التعلم المعرفية

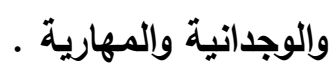

وتعد جدارات التقويم من الجدارات التدريسية الهامة التي يجب أن يمتلكها المعلمين

على اختلاف تخصصاتهم، وذلك لأنها تمثل ركنًا أساسيًا من أركان العملية التدريسية. وتأتي التئي أهمية جدارات التقويم حيث تعد أحد عناصر المنهج، ولها تأثير وأهمية على أهداف العملية

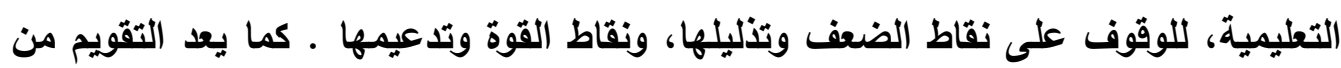

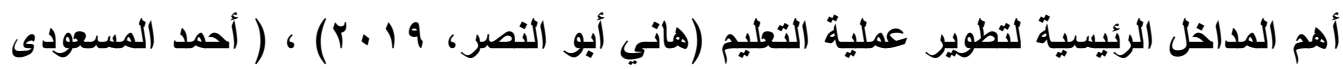

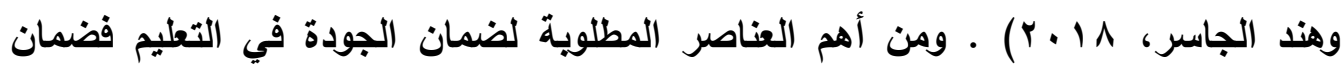
الجودة وتحسين مستويات تعلم الطلاب لا يمكن تحقيقه الا من خلال عملية التقويم ومعرفة

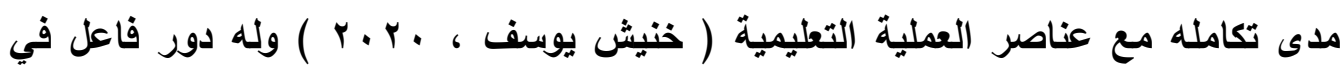

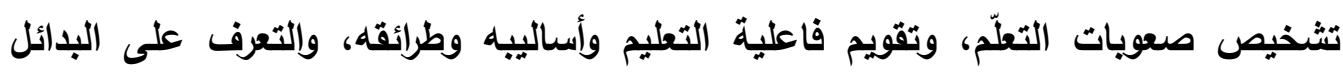

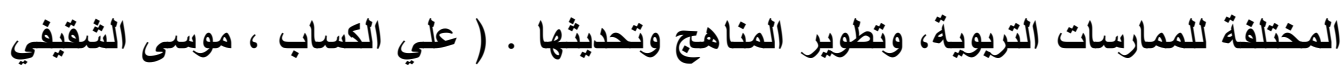

$(r+196$

وعلي الرغم من كثرة الدراسات التي تناولت تنمية الجدارات التدريسية إلا أنها اتفقت أن المعلمين لايهم مستويات كفاءة متدنية فى بعض الجدارات وخاصة الجدارات المتعلقة

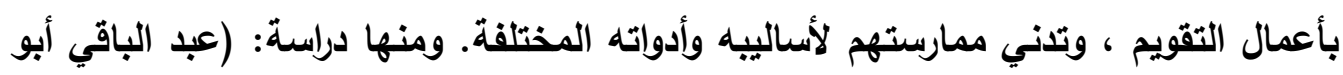

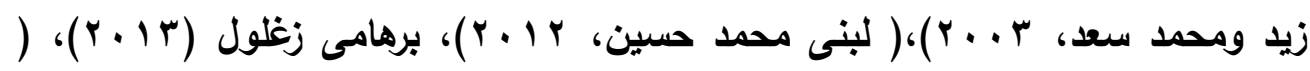

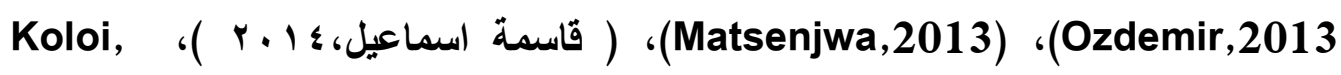

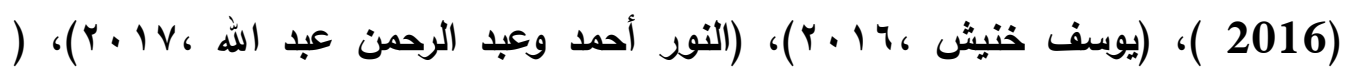

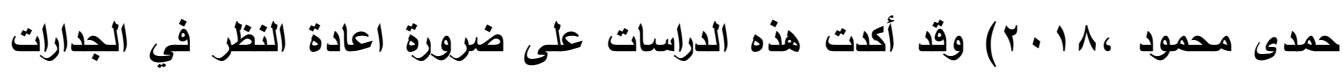
التقويمية الحالية التي تعتمد علي الاختبارات التقليدية وإكتساب بعض التهات المفاهيم والمحتوي النظري للمقررات الدراسية فقط بهدف تصنيف وترتيب الطلاب حسب مستوى تحصيلهم. بل يجب الاهتمام بتدريب المعلمين على بتوظيف أساليب وطرق التقويم التريوي المستخدمة لتشخيص الواقع التعليمي ومعرفة نقاط الضعف والقوة في المنهج المدرسي وعناصره

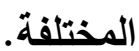


ويناءًا علي ما تقدم فإن الاهتمام بتنمية جدارات التقويم للطلاب المعلمين يؤهلهم

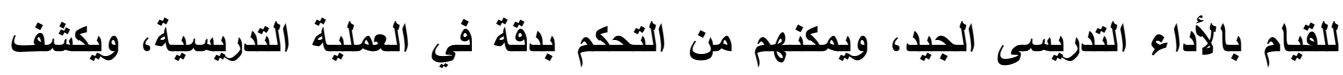

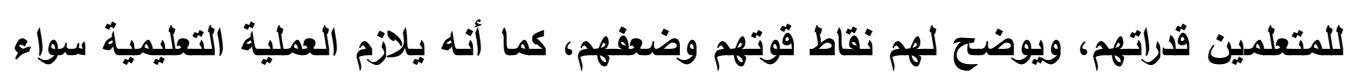
كان ذلك أثناء التخطيط للارس أو أثناء تنفيذه أو بعد نهايته، فامتلاك الطالب - المعلم

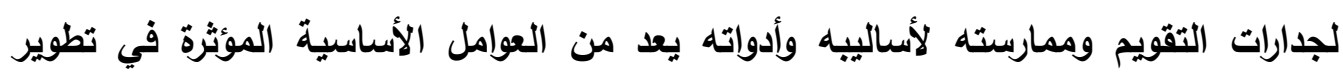
فاعلية العملية التعليمية، فالتقويم لا يهدف فقط الي مراقبة المخرجات النهائية بل هو وسيلة

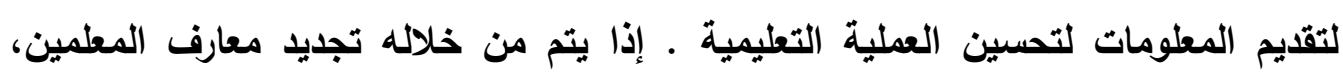
وصقل خبراتهم، ويزيد من ثقتهم بذواتهم المهنية . لذا كان من الضروري الاهتمام بتنمية واكتساب الطلاب معلمى الاقتصاد المنزلى بهنى عمقاً أكبر في تفهر محتوى الموضوعات والمفاهيم والمهارات والممارسات المرتبطة بمقرر

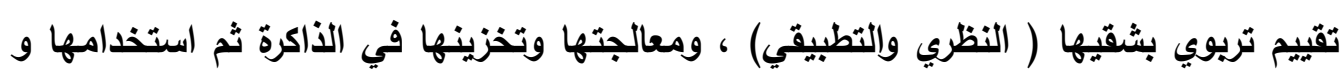

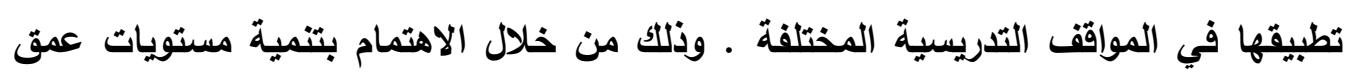
المعرفة العلمية المرتبطة بالمحتوى التعليمى لمقرر تقييم تريوى، حيث أن تنمية عمق المعرفة

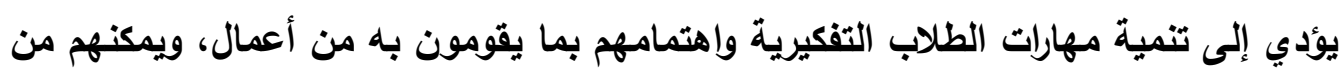

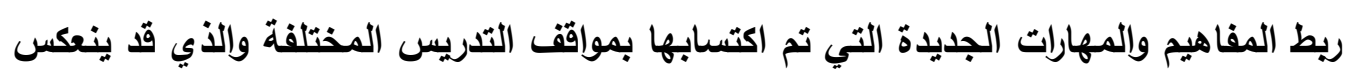
بدوره علي جداراتهم التقويمية وتعزيز ذواتهم المهنية. ويؤكد ( Webb , Webb, 1997,1999) أن مستويات عمق المعرفة تؤدي بالفعل دوراً بارزاً في توجيه عمليات تعلم الطلاب عبر تمكين المعلمين من الانتقال من تقيم

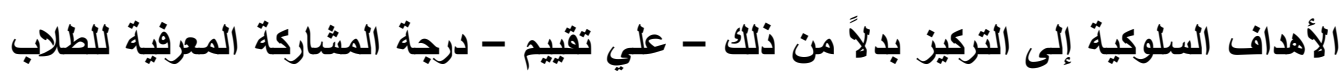

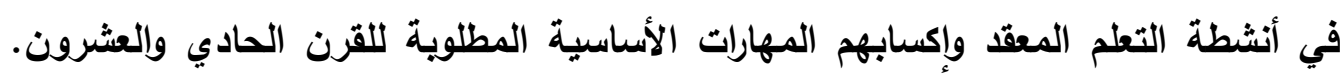
وتوضح ( Hess \& Jones\& Carlock \& Walkup, 2009) أن مستويات عمث المعرفة تركز بشكل أساسى علي قياس استيعاب الطلاب للمفاهيم والمعلومات كما يتطلب بناء العديد من الروابط المنطقية بين الأفكار وترسيخها في البنية المعرفية. إن الاهتمام بتنمية عمق المعرفة العلمية بما تتطلبه من مهارات معقدة للتفكير من

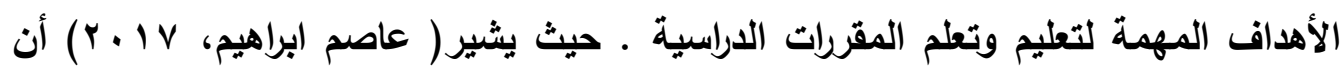
اعداد الطلاب القادرين علي اتخاذ القرارات المناسبة واستخدام طرق التفكير العلمي خلال 
مواقق الحياة اليومية لن يأتي إلا بالبعد عن السطعية فى عملية التعلم و التى تركز على

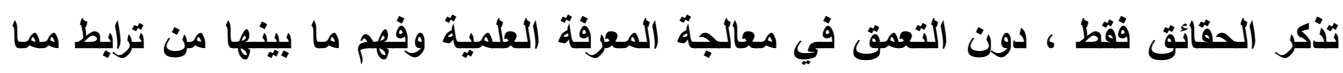

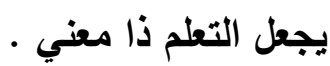

وتعتبر عمق المعرفة أحد المتغيرات الهامة المرتبطة بتطوير المهارات العقلية للطلاب

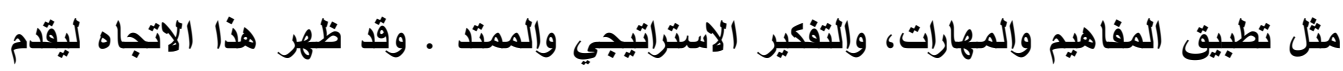
حلا لمشكلة تفكك المعرفة وضعف ترابطها فهو يهتم بكيفية اكتساب الطلاب للمعلومات

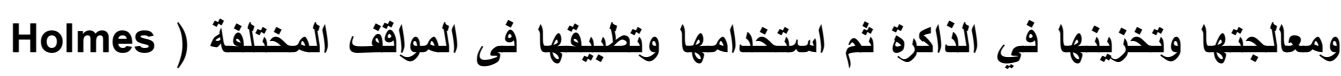

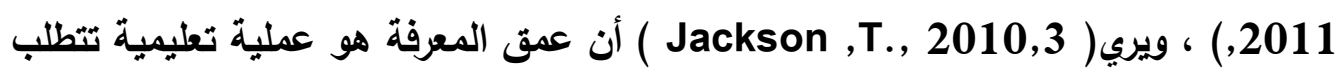

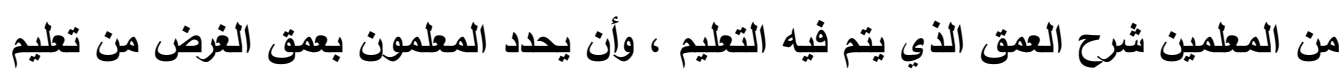

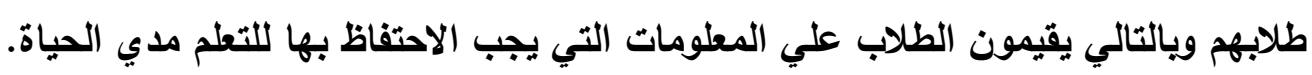

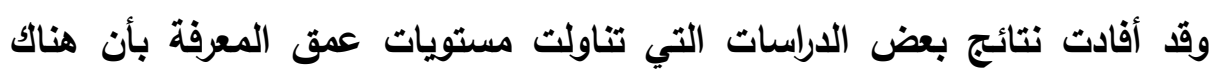

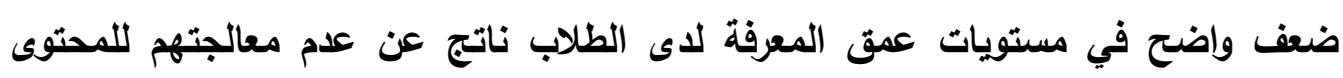

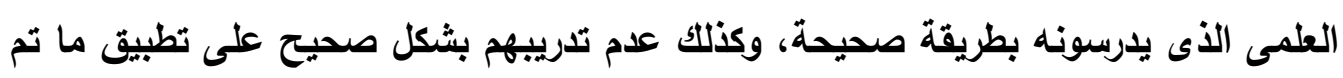

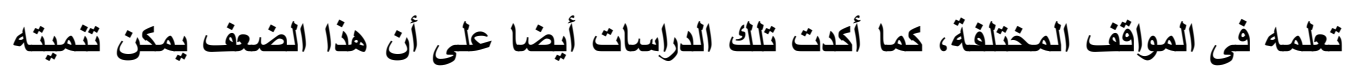

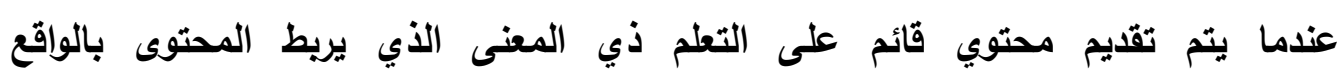

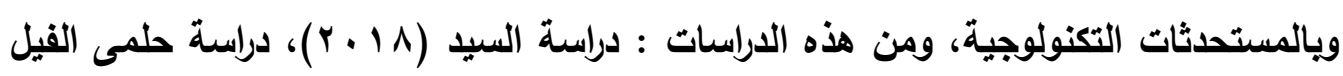

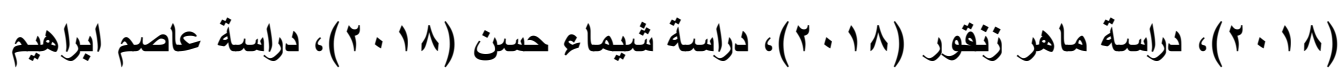

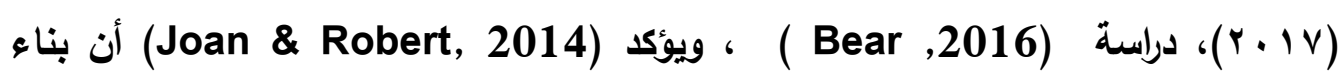

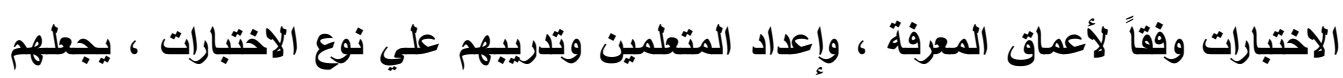

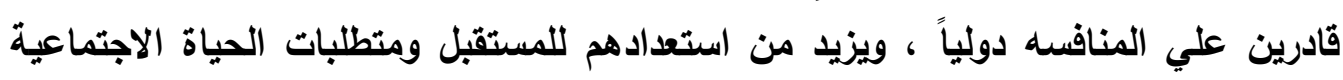

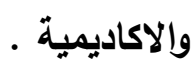

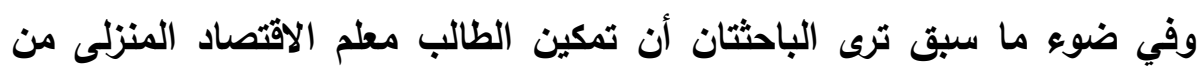

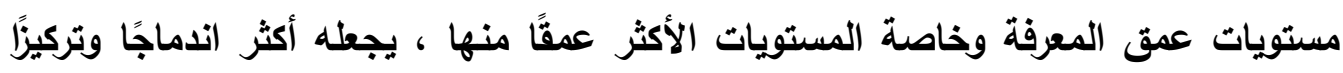

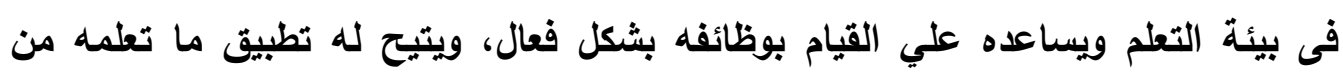
مهارات وأساليب تقويم فى المواقف التدريسية والذى قد يؤثر على تعزيز ثقته فى ذاته المهنية . المهات 
وتعد توكيد الذات المهنية من الصفات الهامة الواجب توافرها في الطالب المعلم

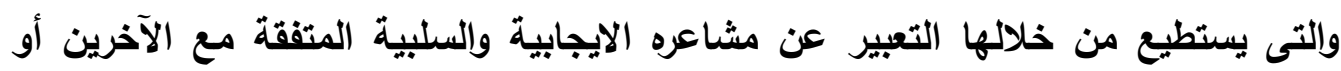

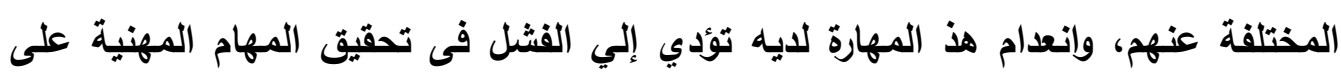

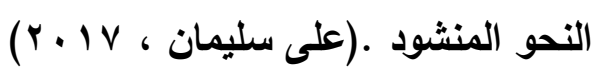

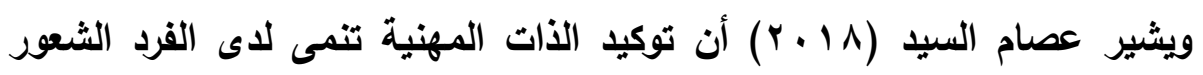
بالتقدير والمكانة والاستقلال والاعتماد علي النفس نحو إدارة الموقف المهنية ، وتزيد مقدرته

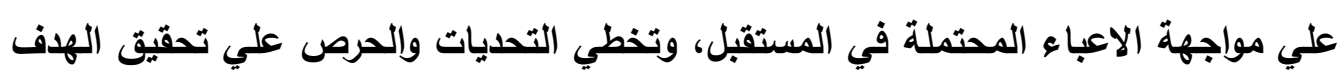
والتوجه الذاتي ، وينعكس ذلك علي خفض معدل القلق والإحباط تجاه المهام و المواقف المهنية والنوجة المئ. وفى هذا الصدد يركز التعليم الجامعى علي بناء شخصية الطالب واعدادهم للاندماج في مجال العمل ومواجهة تحديات الحياة، حيث يبدأ الطلاب في هذه المرحلة باشباع حاجاتهم النفسية والاجتماعية ، ولقد أثارت عديد من الدراسات إلى قصور توكيد الذات لدي لديات

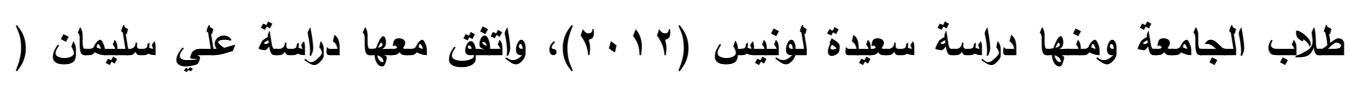

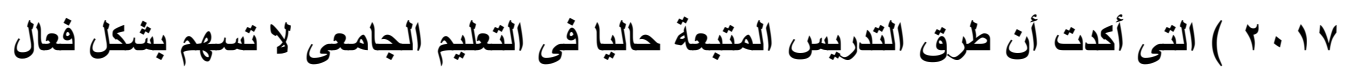
في تعزيز الذات المهنية لاي معلمي المستقبل والذي سوف يؤثز سلباً علي مهاراتهم التدريسية . في ميزية

ويمثل طلاب الجامعه فئة المراهقة المتأخرة ودخولاً لمرحلة الرثد المبكرة وهي مرحلة

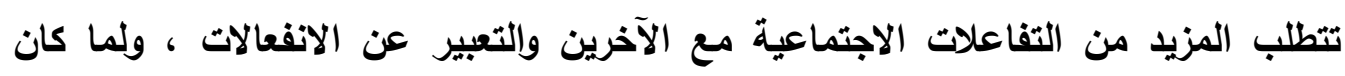

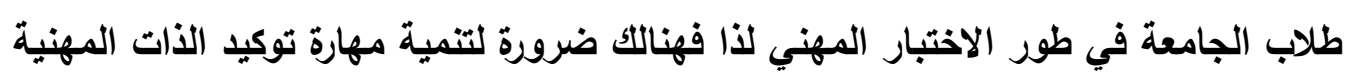

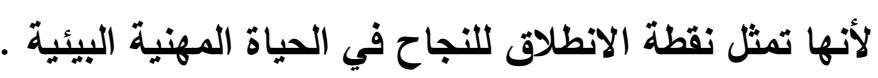

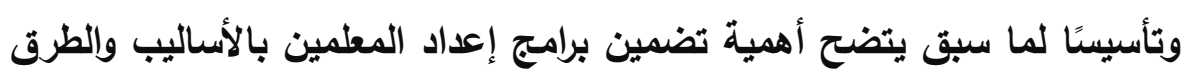

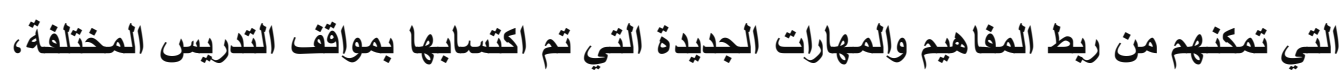
وامتلاكهم للجدارات التقويمية التي تساعدهم علي القيام بوظائفهم بشكل فعال، واثبات ذاتهم المهنية وتحقيق ما يتطلعون إليه من أهداف مهنية مستقبلًا .

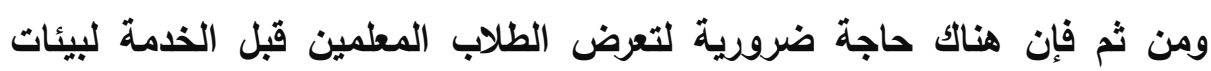
تعليمية تواكب مستجدات العصر وتطوراته في مختلف المجالات، ويتماشي ذلك مع ما نادت 
به الأبحاث التريوية إلي ضرورة تطبيق الأساليب التكنولوجية الحديثة في مجال التعليم، من أجل إعداد جيل قادراً علي توظيف معارفه ومهاراته في حل المشكلات، جيل يعرف كيف يفكر

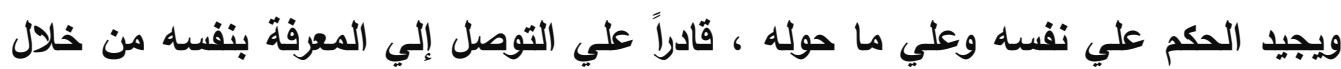

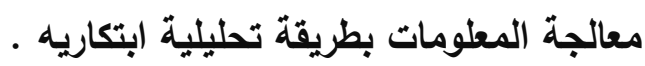
وتعد مراسي التعلم الاكترونية مدخل للتعلم القائم علي توظيف التكنولوجيا الحديثة في التدريس، وتقدم مراسي التعلم شكل جديد من أثكال التعلم الاكتثروني المبني علي النظرية البنائية ، الذى يهدف إلي تعميق فهم المتعلم للمعرفة والمفاهيم بالاعتماد علي أبنية عقله وايجاد سياق حقيقي متع للتعلم، من خلال تصميم مواقف حقيقة لمساعدة المتعلم

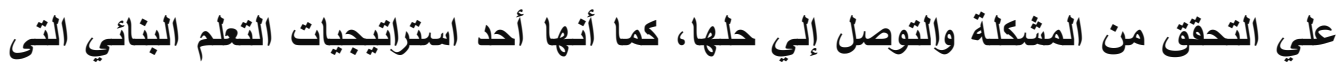
تهدف إلي خلق بيئة تعلم تساعد علي حل مشكلة المعارف الكامنة ( ريهام الغول ، ؛ ( ب ؟ ) ولقد أكلت عديد من الدراسات جدوي مراسي التعلم في تحقيق نواتج العملية التعليمية ، لأنها تتيح للمتعلم توظيف المعارف وتنظيمها وتطبيقها في سياق حقيقي ومنها دراسة( Liu,2010) التي أكلات أن مراسي التعلم ساعدت علي التطبيق المتكامل للمعرفة

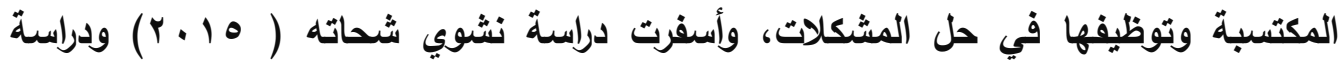

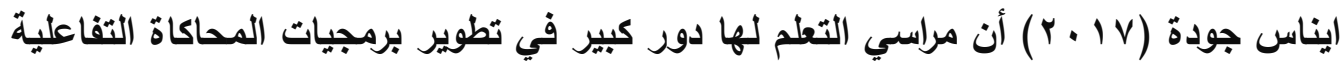
والبرمجة من خلال نمط التفاعل التزامني ببيئة الكترونية.

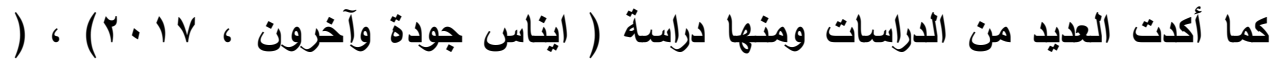

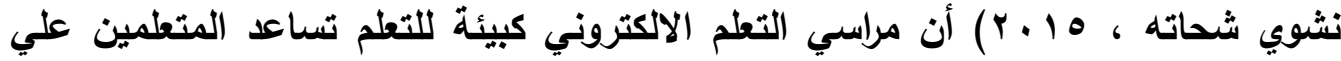
اكساب المهارات والحقائق، وتتظيمها بطريقة تسمح بتطبيقها في الحياة الاكاديمية والاجتماعية ، كما يتأثر نجاح المتعلم أثناء التفاعل الاجتماعي مع الآخرين في السياقات الحياتية المختلفة وجميع مجالات الحياة بدي توكيده لذاته والتعبير الملائم عن نفسه والدفاع عن رآيه ومشاعره وإنفعالاته . وتأسياً لما سبق يتضح أهمية توظيف مراسى التعلم الاكترونية في تدريس مقرر تقييم تريوى، والتى تزيد من فعالية العملية التعليمية، وإكساب الطلاب المعلمين القدرة على التفاعل بايجابية مع المحتوى التعليمى، وإكساب المهارات والحقائق وتنظيمها بطريقة تسمح بتطبيقها في المواقف التدريسية وتدعيم المشاركة والتفاعل بالآراء والخبرات بين الطلاب 
ويعضهم البعض ـ مما قد يسهم فى تحقيق عمق التعلم و تتمية جدارات التقويم وتوكيد الذات المهنية لاى الطلاب المعلمين.

\section{الإحساس المشكلة:}

يعد مقرر " تقييم تربوي " من المقررات التربوية الهامة التي تمثل البنية الأساسية في

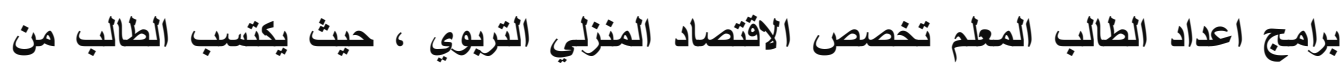
خلال دراسته المقرر العديد من المفاهيم والمعارف المتعلقة بطرق القياس وفوائدها وأنواع التقويم وأهميته في العملية التعليمية، وطرق استخدامه أثناء عملية التدريس، وطرق اعداد الاختبار التحصيلي المبني علي أسس علمية من خلال استخدام جدول المواصفات ، كما يكتسب معارف عن أهم الاتجاهات العديثة في مجال التقويم التربوي وأساليب جمع البيانات، ومما لاشك فيه أن اكتساب الطالب المعلم لهذه المعارف والمصطلحات العلمية أثناء اعداده الاكاديمي سوف تمكنه من القيام بمهامه الاساسية قبل وأثناء ويعد عملية التدريس مما يعزز

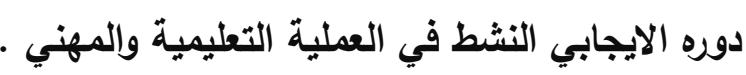

\section{وقد نبع الإحساس بمشكلة البحث من خلال ما يليـ}

1 - تُرس الباحثتان مقرر التقييم التريوي للفرقة الرابعة بجانب قيامهما بالإشراف على طلاب التربية العملية بالمدارس لاحظتا وجود ضعف فى تطبيق المفاهيم والمهارات المكتسبة من مقرر تقييم تربوى، وعدم اعطاء جدارات التقويم الأهمية المناسبة واقتصار التقويم على بعض الأساليب البسيطة التى تقيس التذكر والفهم، وتلني جدارات التقويم الخاصة بتحليل وتفسير نتائج أدوات التقويم وقلة الاستفادة منها في اعطاء تغذية راجعة لتحسين

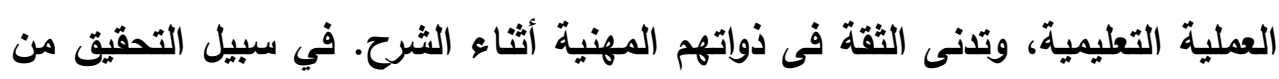

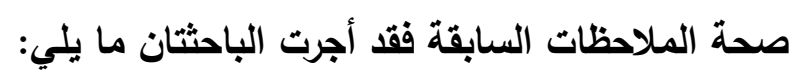
- مراجعة دفاتر تحضير الاروس لبعض الطلاب المعلمين للتعرف على أساليب التقييم

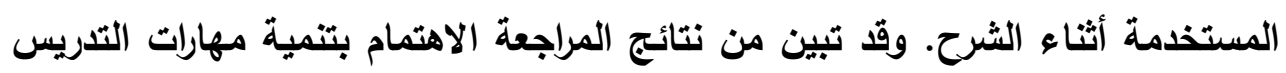

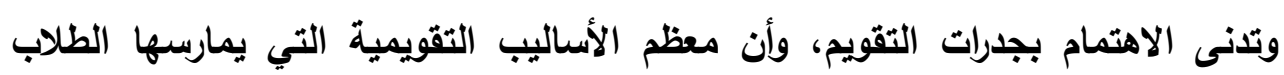
المعلمون أثناء القيام بالتدريس لا يتم إعدادها ويناؤها بصورة صحيحة ولانيات تقيس كل الجوانب لاى الطلاب وتتم بصورة مكررة، ولا تخضع للتحليل أو التفسير، وكل التركيز

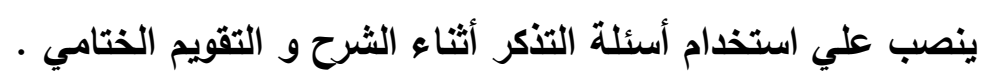


- ماثناء ملاحظة عدد (10) طالباً أثناء فترة التربية العملية (r) بالفصل الدراسي الأول للفرقة الرابعة بواقع حصتين لكل طالب / معلم بهدف التعرف علي واقع ممارساتهم لجدارات التقويم وإلمتمثلة فى( التخطيط ويناء أدوات التقويم - التطبيق والتتفيذ - تفسير وتحليل النتائج ). وقد توصلت نتائج الملاحظة إلى تلني امتلاك الطلاب المعلمين للجدارات التقويمية التي تؤهلهم لتحقيق أهداف العملية التعليمية بكفاءة وفعالية ، كما يظهر علي سلوكهم قلة الثقة بذاتهم المهنية .

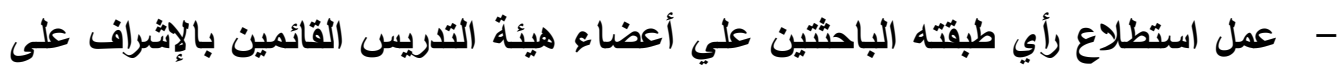

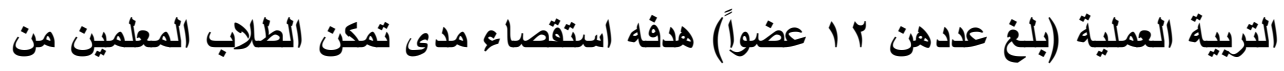
اختيار أدوات وأساليب التقويم التي تتوافق مع خصائص المتعلمين وإستخدام جميع أنواع

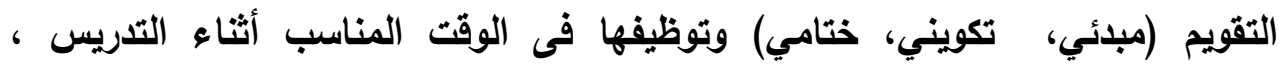
والاستفادة من تفسير نتائج تقويم المتعلمين فى تقديم تفذية راجعة لتحسين أدائهم التدريسى والإلمام بسلوكيات التلميذات، وأكدت حوالى ، 9\% منهن تدني مستوى امتلاك الطلاب لمهارات إعداد أدوات التقويم المختلفة لتقويم التلميذات.

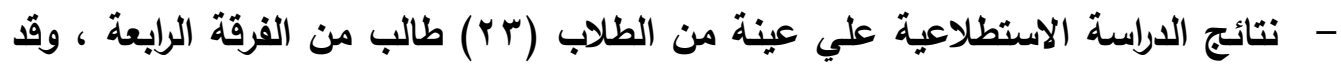
طبق اختبار عمق المعرفة ، مقياس توكيد الذات المهنية، وأسفرت النتائج عن تلني من من التهن مستوي عمق المعرفة، وإنخفاض توكيد الذات المهنية لاي الطلاب المعلمين مما يؤثر علي دورهم المهني في المستقبل. r- نتائج العديد من الدراسات التى أوصت بضرورة تنمية عمق المعرفة لاى الطلاب منها

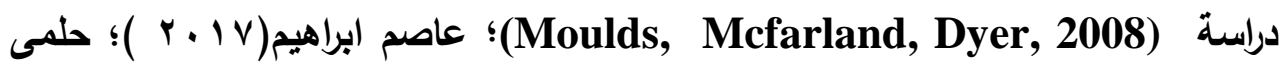

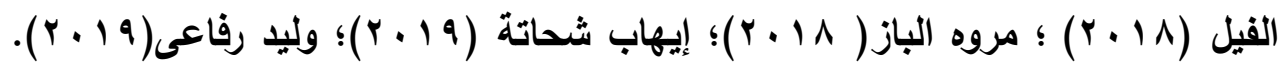
لتنمية قدرة الطلاب على معالجة المعرفة بطريقة صحيحة وتطبيقها في مواقف جديدة . r- توصيات بعض المؤتمرات مثل المؤتمر العلمي الخامس للجمعية العربية لتكنولوجيا

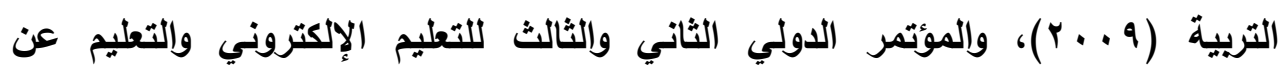

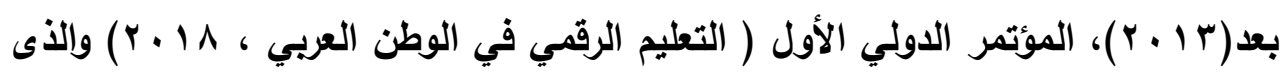
عقد فى القاهرة ـ التي أوصت بالتركيز على الجانب التعليمي والتتربوي، ودعم التعلم الأتي، والمستمر مدى الحياة، وأوصت كذلك بضرورة تطوير وتصميم المجتمعات 
التعليمية الإكترونية التفاعلية، وتوظيفها بشكل فعال لتحقيق الأهداف التعليمية، والتعاون مع التكنولوجيا المتقدمة ومواكبة التغيرات العالمية الحديثة التي لا يحدها زمان أو مكان .

צ - نتائج عديد من الدراسات والبحوث التي أكدت علي المزايا والإككانيات التي تقدمها مراسى التعلم الاكترونية وسبل الاستفادة منها في المجال التعليمي لمقررات تعليمية مختلفة

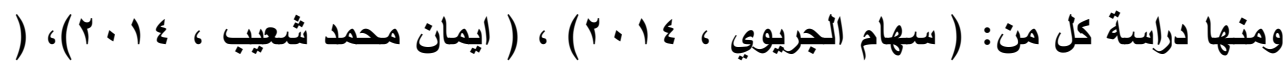

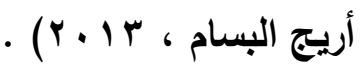

ه - توصيات الهيئة القومية لضمان جودة التعليم والاعتماد بجمهورية مصر العربية بضرورة

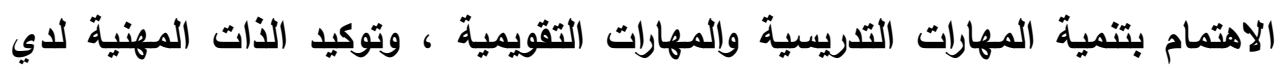
الطلاب المعلمين ، وجعلتها مواصفات عامة واجب توافرها لدي خريجي كليات التربية عامة والأقسام التريوية بجميع القطاعات. (الهيئة القومية لضمان جودة التعليم والاعتماد

$$
\text { (r. Ir. }
$$

وفقاً لما تقدم واستجابة لما أوصت به المؤتمرات والدراسات السابقة من ضرورة الاهتمام بإعداد الطلاب المعلمين، والاستفادة من المستحدثات التكنولوجية في تطوير برامج تدريبهم والتي أظهرت الحاجة للبحث الحالي التي جاعت فكرته فئه كماولة لتنمية مستويات

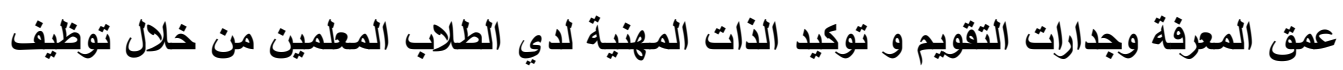
واستخدام مراسى التعلم الالكترونية في تدريس مقرر تقييم تريوى .

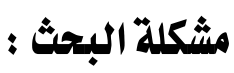
فى ضوء ما سبق تتحدد مشكلة البحث الحالى في تلني مستوى عمث المعرفة العلمية

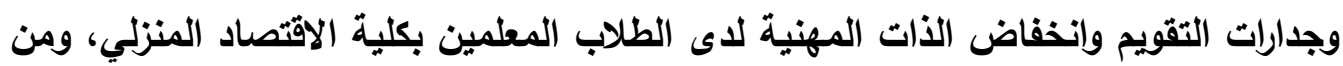
ثم فإن مشكلة البحث يمكن صياغتها في السؤال الرئيسي التالي : هل توظيف مراسي التعلم الاكتروني في تدريس مقرر التقييم التربوي له دور في تنمية مستويات عمث المعرفة وجدارات التقويم وتوكيد الذات المهنية لاي الطالب المعلم بكلية الاقتصاد المنزبي؟ 


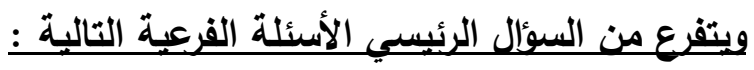

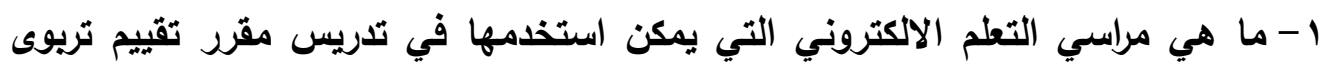

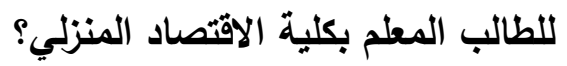

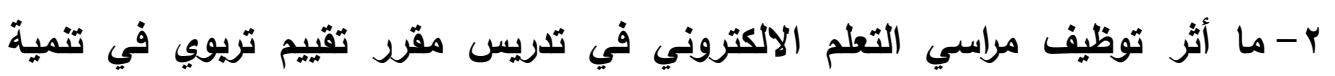

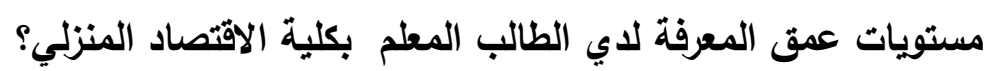

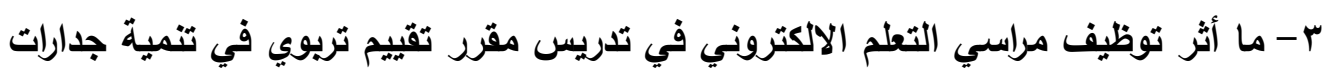

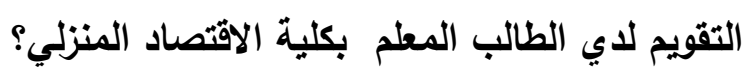

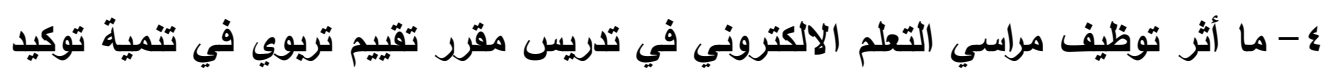

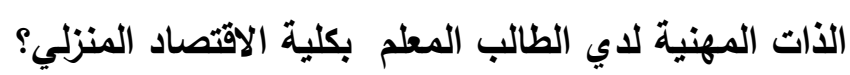

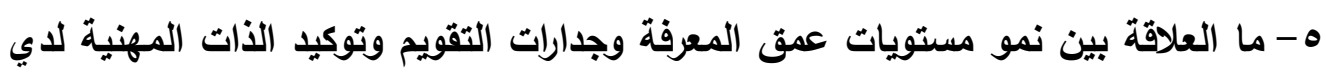

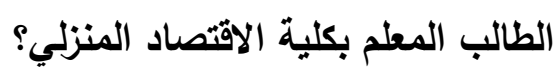

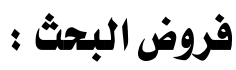

يسعي البحث الحالى التحقق من صحة الفروض التالية :

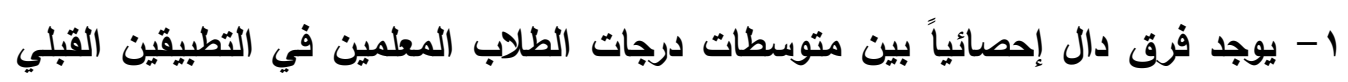
والبعدي لاختبار عمق المعرفة لصـالح التطبيق البعدي.

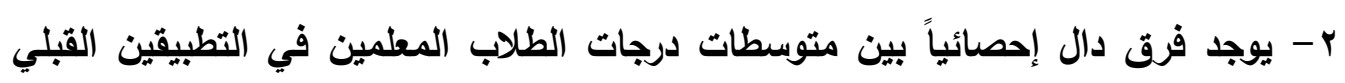

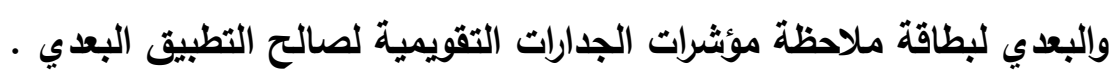

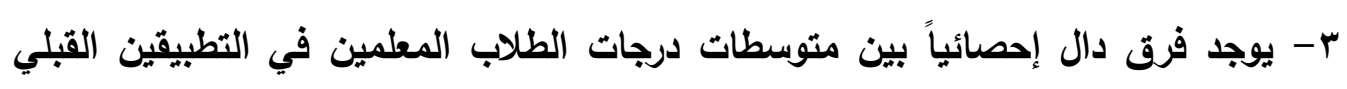

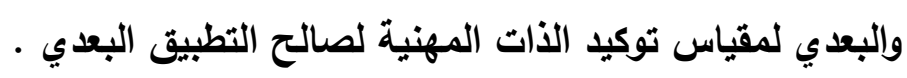

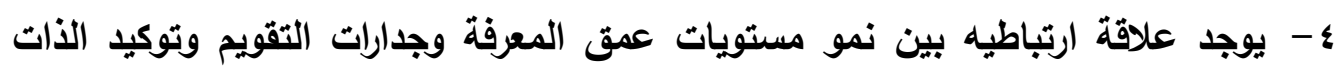

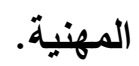




\section{يجهدف البحث إلي :}

- - دراسة أثر توظيف مراسى التعلم الاكترونية فى تنمية مستويات عمق المعرفة وجدارات

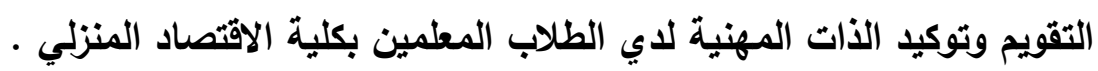
- - الكثف عن طبيعة العلاقة بين مستويات عمق المعرفة وجدارات التقويم وتوكيد الذات المهنية.

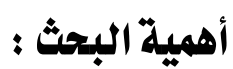

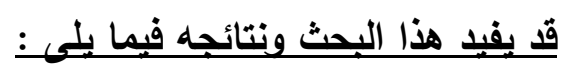
ا - يعد هذا البحث استجابة موضوعية لما يتطلبه الوقت الراهن نتيجة للأزمات التي يتعرض

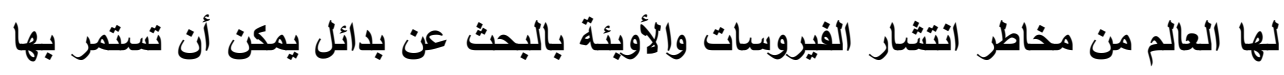
عملية التعلم حفاظاً على المتعلم وكحل لهذه الأزمة.

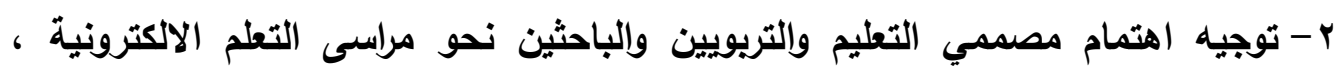

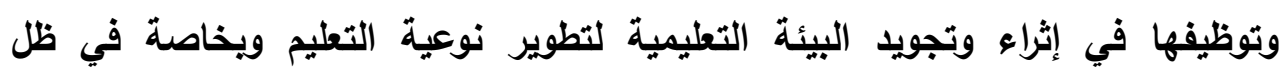
التغييرات المستحدثة في النظام التعليمي . ب- يشكل البحث إطاراً مرجعياً يمكن الاعتماد عليه في إثراء العملية التدريسية للتغلب على القصور في جدارات التقويم التي يمتلكها الطالب المعلم مما ينعكس علي العملية التعليمية تطويرا وتنمية، وتحقيقا للاهداف المرجوة. ع - يقدم هذا البحث نموذجاً يمكن الاسترشاد به في توظيف مراسى التعلم الالكترونية في تنمية عمق المعرفة وجدارات التقويم وتوكيد الذات المهنية لاى الطلاب المعلمين. ه - تزويد القائمين على التوجيه والإثراف في مجال الاقتصاد المنزلي بقائمة لأهم الجدارات التقويمية التي ينبغي على المعلمين امتلاكها. צ- توجيه مطوري برامج إعداد الطلاب المعلمين، بضرورة الاهتمام بتضمين توكيد الأتات المهنية لاى الطلاب المعلمين ضمن هذه البرامج، بما يسهم في تنمية مقدرتهم التدريسية والمهزية بشكل علمي سليم. 
V يقدم البحث أدوات تقويمية تتمثل في:اختبار عمث المعرفة للمحتوى العلمى بمقرر تقييم تريوى، ويطاقة ملاحظة الجدارات التقويمية، ومقياس توكيد الذات المهنية، يمكن الإقادة منها في إعداد أدوات تقويمية مماثلة، وفي برامج تعليمية أخرى. حدود البجثث :

\section{اقتصر البحث الحالى على ما بلإلى:}

- مقرر تقييم تريوى لطلاب الفرقة الرابعة الشعبة التزيوية بكلية الاقتصاد المنزلي - جامعة

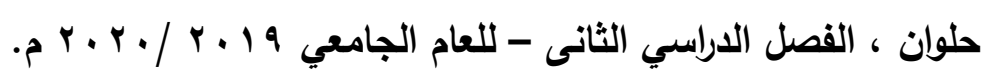
- - الطلاب المعلمين المقيدين بالفرقة الرابعة الشعبة التريوية بكلية الاقتصاد المنزلي. أدوات القياس ومواد المعالجة للبحث : اعتمد البحث الحالى علي الأدوات التالية : (إعداد الباحثتان ) أولاً : أدوات القياس : 1- اختبار مستويات عمق المعرفة العلمية المتضمنة بمقرر تقييم تريوى.

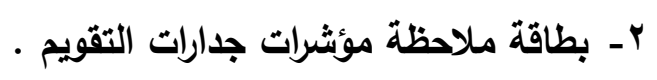

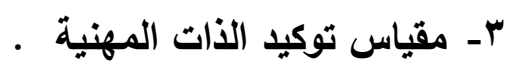
ثانياً : مادة المعالجة التجريبية : - تهيئة بيئة تعلم الكترونية من خلال توظيف مراسى التعلم الاكترونية لتدريس مقرر تقييم

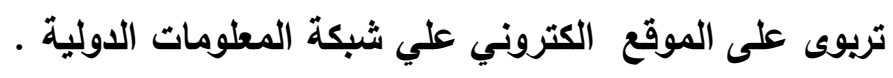

\section{منهج البحث والتصمييم التجريبى:}

نظراً لطبيعة البحث الحالمى فقد اعتمد على المنهين الآتين:

1- المنهج الوصفى: وذلك في وصف وتحليل البحوث والدراسات السابقة ودراسة الاتجاهات الحديثة في مجال التدريس والتعلم باستخدام مراسى التعلم الاكترونى، واعداد أدوات

$$
\text { البحث . }
$$

r - المنهج شبه التجريبى ذو المجموعة الواحدة القائم علي القياس القبلى والبعدى وذلك البك للكثف عن أثر المتغير المستقل (مراسى التعلم الالكترونى)على المتغيرات التابعة وهى:

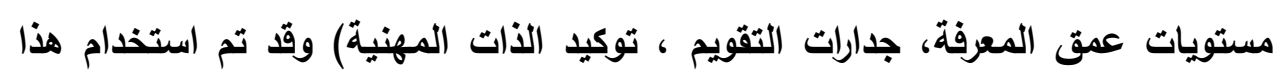


المنهج لان المقرر يلرس لطلاب الفرقة الرابعة ونتيجة لازمة كورونا التي حدثت اثثاء

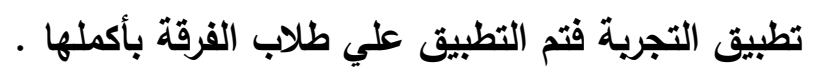

مصطاحات البحث :

* تعرف مراسي التعلم Anchored Learning اجرائياً:استراتيجية تعليمية قائمة علي توظيف المستحثثات التكنولوجية بهرف اتاحة الفرصة أمام المتعلمين للتعايش مع بيئة التعلم وتوظيف المعارف وتنظيمها وتطبيقها أثناء عملية التدريس .

* تعرف مستويـات عمق المعرفة Depth of Knowledge levels إجرائيًا بأنها: أحد أنواع التفكير المركب الذي يقوم من خلاله الطالب المعلم بتنظيم المعارف والمهارات

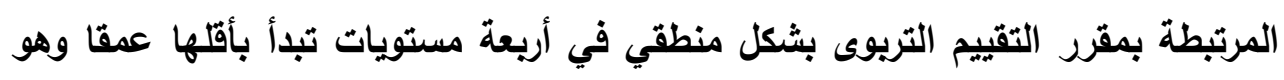

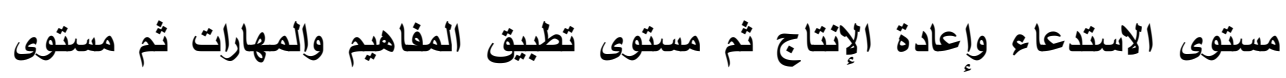

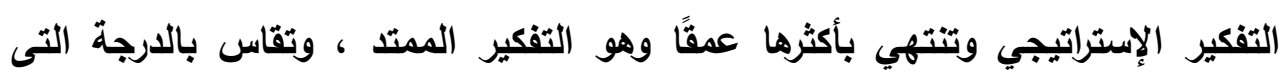
يحصل عليها الطالب المعلم في اختبار عمق المعرفة المعد لذلك في البحث الحالي . * تعرف الجدارة Competencies اجرائيا بأنها: الحد الضروري اللازم إكسابه من المعارف والمهارات لدى الطالب المعلم بكلية الاقتصاد المنزلى لأداء مهام عملية التدريس بمستوي عالي من الاتقان والكفاعة والفاعلية . يعرف التقويم Evaluation اجرائيًا بأنه: عبارة عن إجراء يتطلب من الطالب المعلم

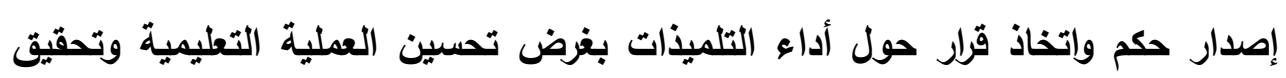
الأهداف التربوية . * تعرف جدارات التقويم Evaluation Competencies اجرائيًا بأنها: مجموعة من المفاهيم والمهارات التي ينبغى أن يمتلكها الطالب معلم الاقتصاد المنزلى وتشمل عمليات

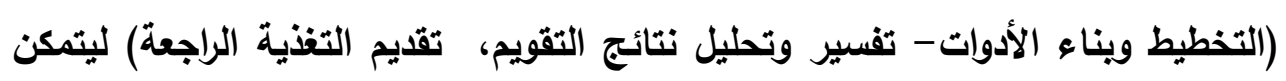
من أداء مهام التقويم لحقق الأهداف التريوية المتعلقة بتدريس الاقتصاد المنزلى. وتقاس الادوات بالدرجات التي يحصل عليها الطالب/ المعلم، في اختبار مستويات عمق المعرفة في المجال المعرفي، ويطاقة ملاحظة جدارات التقويم في المجال الأدائي . 


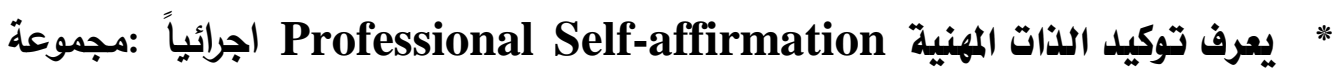
من السلوكيات والقيم والمعتقات والطموحات المستقبلية المرتبطة بمهنة التدريس والتى يؤدى اكتسابها إلى تعزيز ثقة الطالب المعلم بنفسه أثناء عملية التدريس وادراكه لذاته

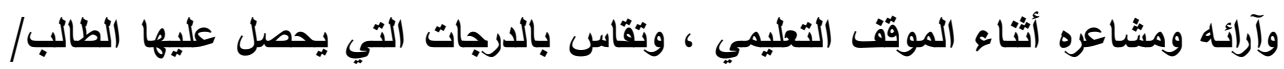

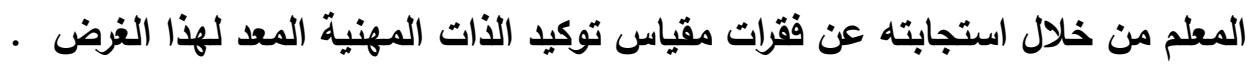

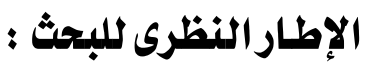

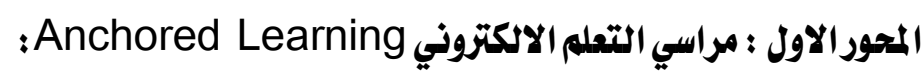

بُبنيت مراسي التعلم الاكتروني علي مبادئ ونظريات مشتقة من نظريات تريوية منها النظرية البنائية القائمة علي مبادئ الاكتثاف الموجه ،ونظريات التئيات التعلم الاجتماعي المعتمده

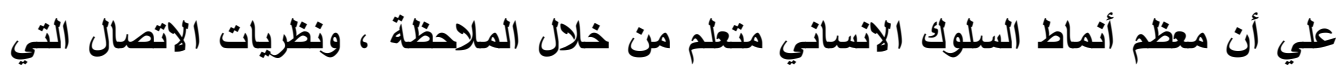
تؤكل علي اتاحة الفرصة للطلاب للتواصل والتفاعل فيما بينهم أثناء التعلم. كما تُعد مراسي التعلم مدخلاً لاكتثاف بيئة التعلم ، حيث تتمركز الأنثطة التعليمية

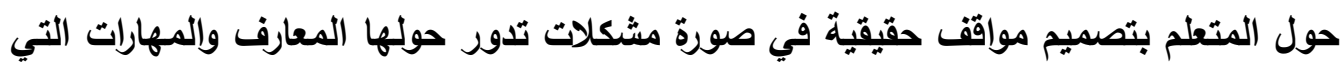

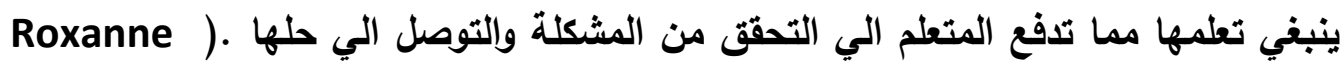
\&Kathy . 2007) مفوم مراسي التعلم الاكترونية : يعرف ( Ruzic \& Oconnell, 2007 ) مراسي التعلم بأنها " استراتيجية تعلم لاكتثاف البيئة التعليمية ، تعتمد علي تصميم جميع الانثطة العلمية حول المواقف الحقيقة لتؤهل المتعلمين لحل المشكلات التي تواجههم ويري ( Yusung Heo , 2007 ) مراسي التعلم بأنها : " بيئة تعليمية تساعد الطلاب علي توليد الأفكار والاهتمام بالمعارف ، تمكنهم من استكثاف المحتوي العلمي بوجهات نظر

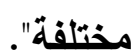

وتعرفها نسرين الحديدي( r ب r) بأنها مدخل تعليمي يكسب الطلاب المعارف أثناء محاولتهم حل المثكلة التعليمية من خلال بعض الممارسات التعليمية المحددة سواء كانت

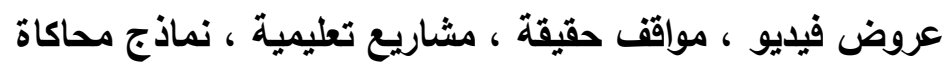


ويعرفها ( Kumar, 2010 ) بأنها نموذج للتعلم قائم علي حل المشكلات الصعبة

والمعقدة ، ومثاركته المتعلم في مواقف حقيقيه يتم تبادل الأفكار والآراء الناقدة . ويشير (Roe,2014) إلي مراسي التطلم بأنها أسلوب يعتمد علي استخام مشكلة

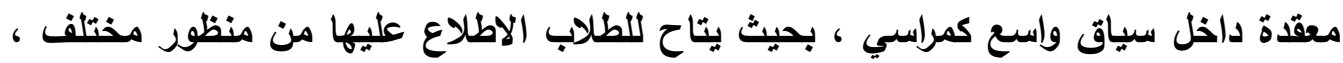

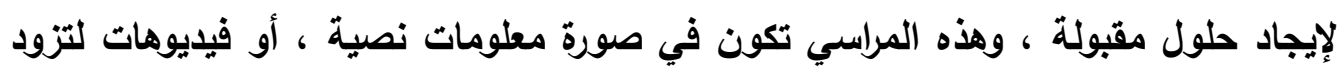
الطلاب بمطلومات عامه حول المشكلة ، ويُكون خبرة تعلم مشتركة .

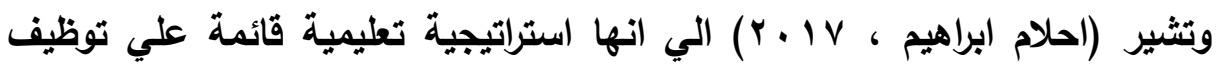
المستحدثات التكنولوجية كمراسي للتطلم مثل الإنفوجرافيك ، الفصول الافتراضية ، المناقثشات الجماعية المتزامنة وغير المتزامنة ، تطبيق الواتس آب Watspp لبناء سياق تعليمي حقيقي وممتع يشجع علي التطم النشط . ومما سبق يتضح ان مراسي التعلم مدخل تعليمي الكتروني بنائي مبنية علي مبادئ الاكتثاف الموجه وتنظر للطالب كمشارك نثط في عملية التعلم واكتساب خبرات تعليمية ، من خلال التواصل الفعال فيما بينهم ، وملاحظة سلوكياتهم اثناء عملية التعلم .

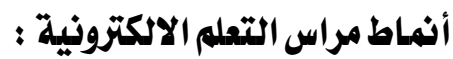
تعددت أنماط واشكال مراسي التعلم الي يمكن توظيفها في بيئات التعلم ، حيث يتم عرض المحتوي التعليمي من خلالها مثل : عروض الفيديو أو الرسوم المتحركة أو المحاكاة ، وتمثلت أنماط مراسي التعلم الاكترونية في البحث الحالي في :

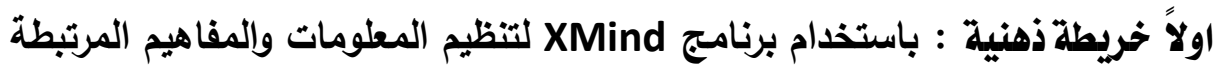

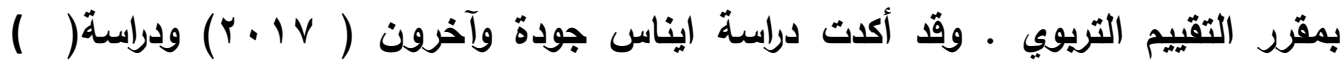

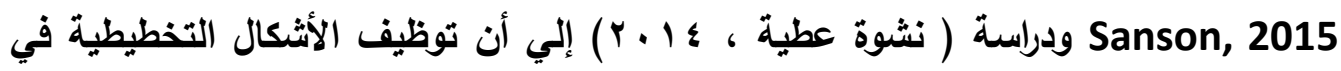
التعليم يسهل تنظيم المعومات وسهولة استرجاعها ومعرفة العلاقات بين المفاهيم والعناصر مما يؤدي الي تنمية مهارات المتطلم في تنظيم العناصر والمفاهيم وترتبيها والاحتفاظ بها ـاتهات

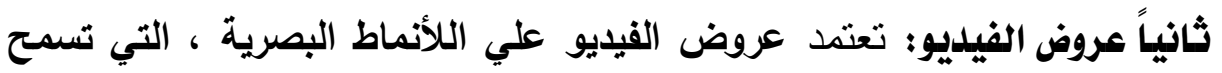
للطلاب بتطوير مهاراتهم ومعارفهم ، ويفضل أن تصاغ في شكل قصصي ، وتدعم بالأنثطة

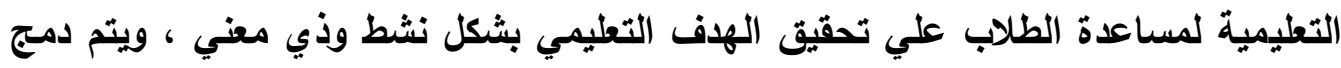
الفيديو وتكامله مع المحتوي التعليمي لتدعيمه وريط معارف وخبرات المتعلم السابقة 
بالمعارف الجديدة التي يكتشفها ـ وهذا ما أكدته دراسة ( Wojtowicz, 2011 ودراسة

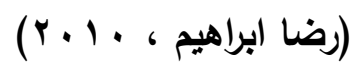

ثالثاً Class Room: احد تطبيقات الحوسبة السحابية Cloud Computing

ومنصة تعليمية لتبادل المواد الاراسية والمستتدات الأخرى المتعلقة بها مع الطلاب ، ويسمح

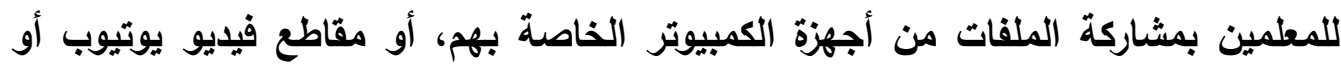
روابط جوجل درايف أو أي روابط أخرى ، ويمجرد حفظ وتخزين هذه المواد على الانترنت

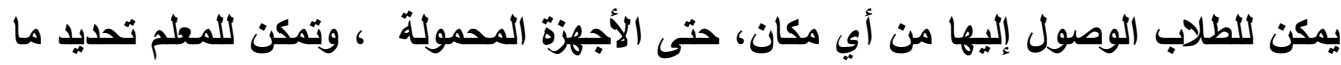

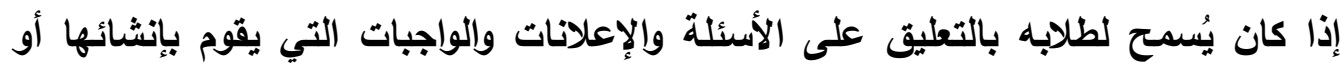
يكون بإمكانهم النشر فقط. يمكن للمعلم أيضًا اختيار أن يكون هو الثخص الإعله الوحيد الذي يمكنه النشر والتعليق في فصله.

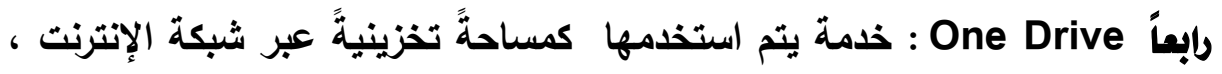

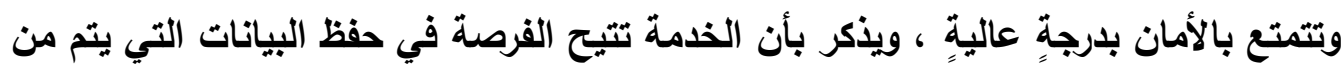

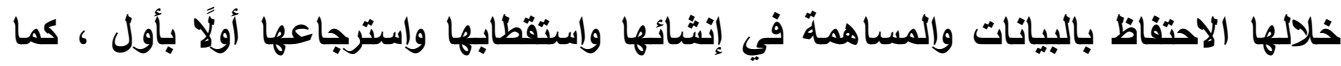
يمكن للمستخدم الاستعانة بهذه الخدمة لغايات تخزين البيانات الحساسة التي يمنع الوصول إليها كالبيانات الضريبية والصور وغيرها، بالإضافة إلى إمكانية تصميم العروض التقديمية وجداول البيانات والاحتفاظ بها عبر الإنترنت. خامساً نماذج المحكاة :وهي تعمل علي اكساب المتعلم المعارف والمهارات علي أختلاف مستوياتها ، حيث تم تسجيل بعض الفيديوهات لبعض الطلاب المتعلمين اثناء عملية التدريب الميداني وعرضها علي الطلاب . سادساً المواقع الاككترونية : حيث تساعد الطلاب علي تجميع بيانات ومعلومات حول المشكلة التعليمية ، وتمكنه من الوصول لحلها ، ويفضل تقديم مراسي التعلم في شكل مواقف حقيقة ، حيث تقلم المشكلة التعليمية في شكل واقعي وطبيعي تمكن الطالب واستخدام المفاهيم التي تم التوصل إليها في المواقف الحياتية . سابعاً الانشطة التفاعلية : مجموعة من الانشطة التفاعلية المتنوعة التي تساعد الطلاب علي زيادة المعارف واكتساب المهارات التعليمية . 
خصائص مراسي التعلم الالكتروذي :

تُعد البيئات التعليمية التفاعلية الاسلوب الافضل لتقديم التعليم والتدريب حيث توفر

بيئة لا مركزية تفاعلية متكاملة من الوسائط تراعي الفروق الفردية بين المتعلمين ولديها

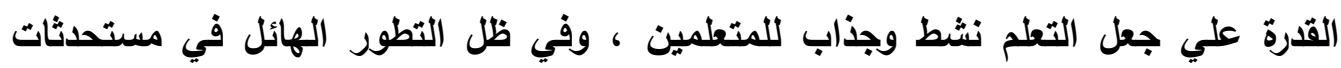

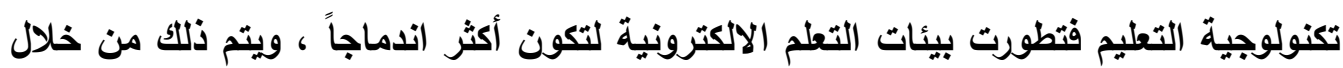
توظيف مراسي التعلم القائمة علي تطبيقات جوجل التفاعلية ، ولمراسي التعلم الاكتروني

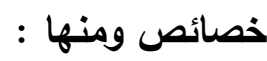
• تعالج مشكلة المعرفة الكامنة " Inter Knowledge" عن طريق خلق بيئات التعلم التي تتيح للمتعلم البحث عن المعلومات والمعارف لفهم وحل المشكلات . تتمركز حول المتعلم من خلال بناء المعرفة وتتظيمها ومقارنتها بالمعلومات الجديدة

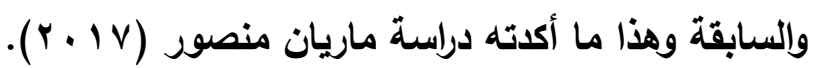

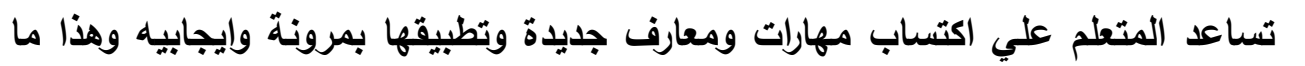

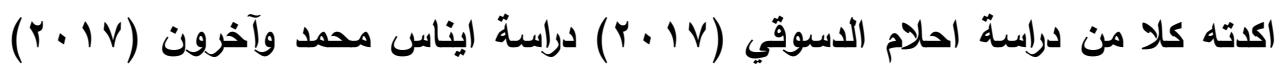
التي توصلا الي أن مراسي التعلم ساعدت علي تنمية مهارات ادارة التعلم الالكتروني وتتمية مهارات البرمجة.

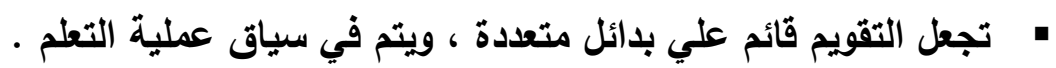

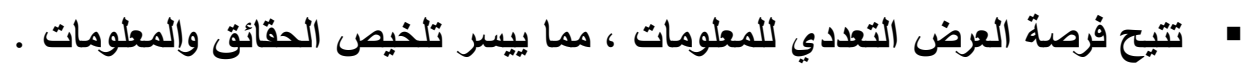
• توفر للمتعلم مصادر متنوعة في تعلمه علي مواقع تخزينة واسعه مما تساعد علي التغذية الراجعه .

\section{مميزات مراسي التعلم الإلكترونية :}

تتسم مراسي التعلم الالكتروني بعدة سمات تميزها في بيئات التعلم الالكتروني الفعال

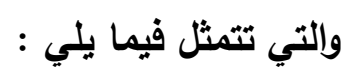
ا - تنمي مهارات التعلم الذاتي والتعلم المستمر ومهارات التفكير العليا ومنها مهارات التفكير الناقد ومهارات حل المشكلات والتفكير التحيلي التأملي . 
r- تزيد من فاعلية الطلاب وتتمية الاتجاهات الايجابية نحو التعلم وتطور من ثقته

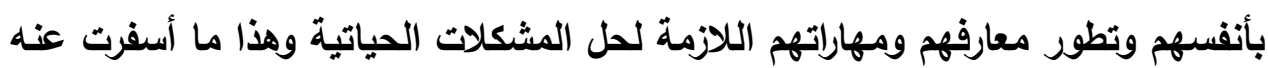

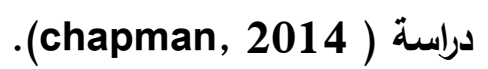

r- تعزز العمليات المعرفية ليصبح التعلم ذو معني بإدراك المتعلم المعلومات الجديدة كأداة

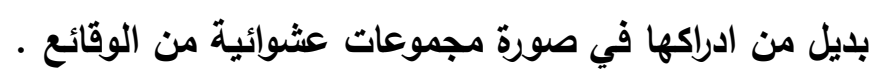

ع - توفر التوجه واللدعم والمساعدة اثناء التعلم من خلال حل مشكلات المواقف الحياتية .

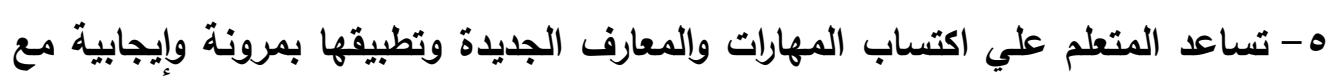

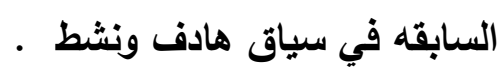
צ- تنمي لدي المتعلم التفاعلات المتعدده ، وتثمل التفاعل بين الطلاب ويعضهم ، وينينهم

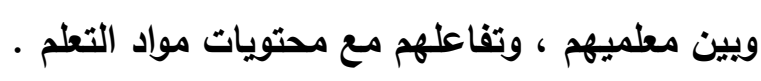

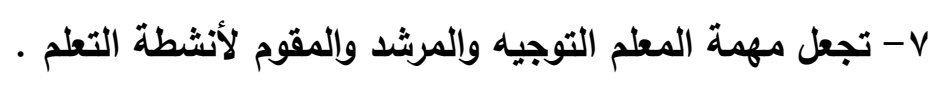
1- تثمل بيئة المراسي علي مصادر ثرية تمكن الطلاب من استكشافها كما يمكن إعطاء

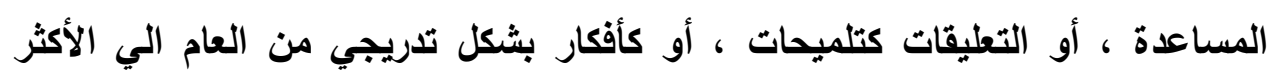

تفصيلاً (Hartanto \& Reye, 2013) 9 - تزود المتعلم بالتغذية الراجعة الفورية لمعرفة مستواه ومستوي تقدمه .

\section{مبادئ تصميي مراسي التعلم الالكترونية :}

يوجد مجموعه من المبادئ التي ينبغي مراعاتها عند تصميم مراسي التعلم الالكتروني

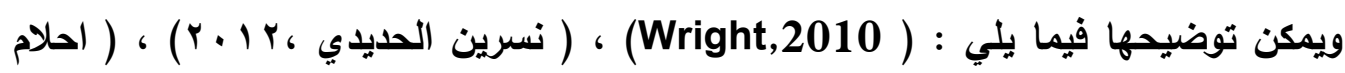

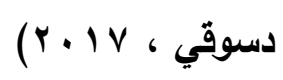

• لابد أن تتميز المرسي بالتشويق بعرض موقفاً مشوقاً ، أو مشكلة حقيقة ، أو قصة

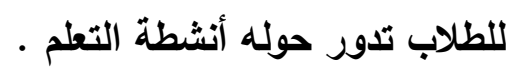

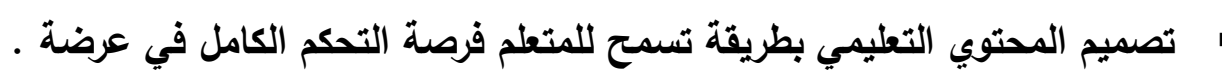

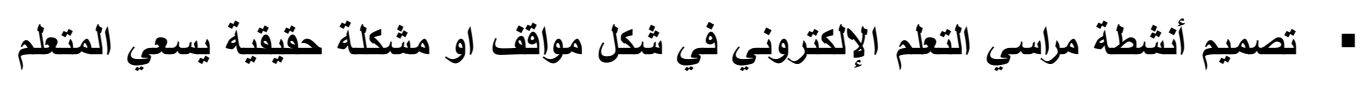

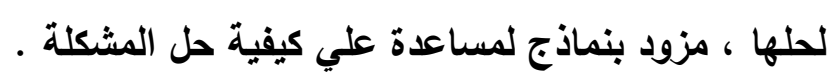

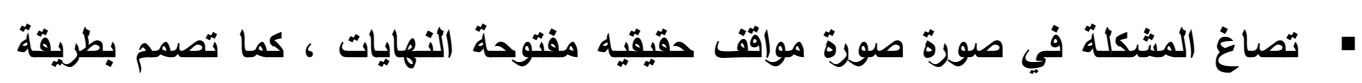
تساعد المتعلم علي توظيف ما تم تعلمه ويأتون بنهايات محتمله . 
• تصميم مشاريع تعليمية تعتمد علي ربط المعارف السابقة بالمعارف الجديدة التي تقدم - للمتعطم

• تثمل بيئة التعلم القائمة علي مراسي التعلم علي مصادر ثرية تمكن المتعلم استكشافها ـ

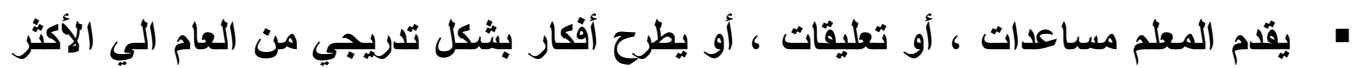
تفصيلاً.

المحور الثاني: مستويـات عمق المعرفة Depth of Knowledge واجه تصنيف بلوم السداسي للمعرفة بعد الانتقادات وخاصة أنه حدد التقويم كأعلى

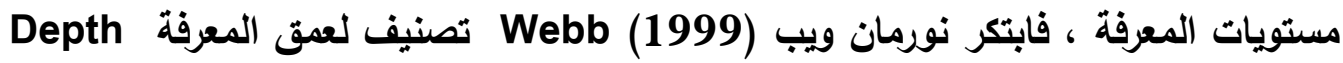
of Knowledge (DOK) والتقييم، ويتدرج هذا التصنيف وفقا لمستويات عمق المعرفة، واستهدف ربط معرفة الطالب الجديدة بمعرفته السابقة مما يساعده على خلق أفكار متكاملة ومترابطة سعيا للوصول للتعلم ذى المعنى وزيادة قدرة الطالب على فهم وتمبيز الأفكار المختلفة والمقارنة بينها (حلى

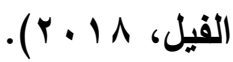

وقد تعددت وجهات نظر العلماء والباحثين التريويين في مجال علم النفس حول مفهوم مستويات عمق المعرفة فقد أشارت (Matthew, et. al.,2013) أن مستويات عمق فئ فئن المعرفة أحد أنواع مستويات التفكير التي تؤاءم بين المعايير والمحتوى لتقييم الطالب كما أنه لا يعتمد على الأفعال مباشرة وإنما يعتمد على الهذف من سياق تلك الأفعالـ ويشير ) Baer, 2016) ( Thomas, يحدث بينها تفاعل من خلال الاستقصاء والمناقثة وحل المشكلات، ويرى (2017 أن مستويات عمث المعرفة تتمثل في قدرة الطالب على معالجة المعلومات الجديدة

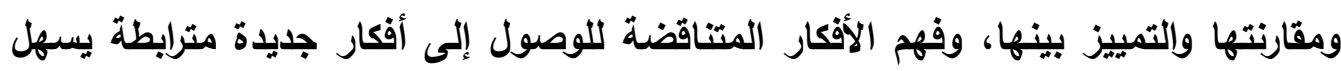
عليه تطبيقها في الحياة العملية ، ويرى البعض أن مستويات عمق المعرفة تأخذ في الحسبان تعقد المحتوى الذي يجب أن يتعلمه الطلاب، كذلك تعد للمهنة التي يجب على الطلاب القيام بها. (Hess , K., et al., 2009 


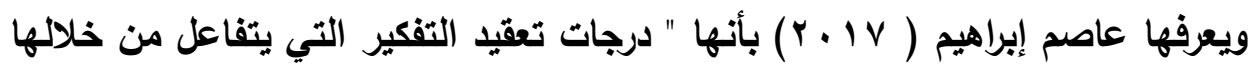

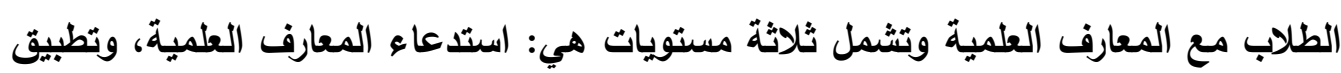

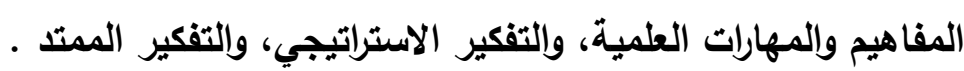

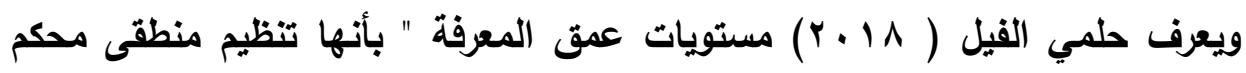
للمعارف والمهارات التي يجب أن يتمكن منها الطالب في أي مجال دراسي وفقا لارجة عمقها

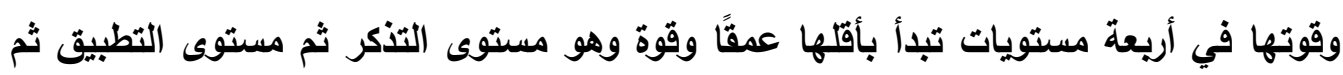
التفكير الاستراتيجي وأخيرا التفكير الممتد وهو المستوى الأكثر عمقًا وقوة.

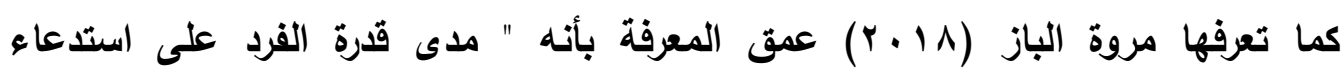

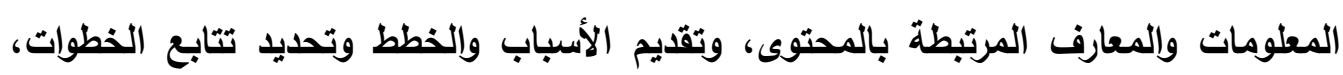
واقتراح الطرق والحلول لاكتساب هذه المعرفة العلمية والتريوية.

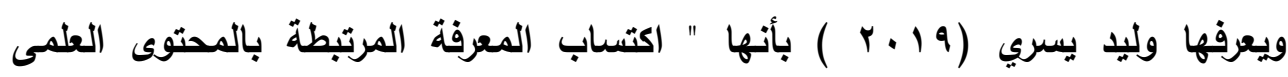
وتنظيمها وفقا لارجة عمقها في أربعة مستويات تبدأ بمستوى التذكر واعادة الإنتاج ( الأقل

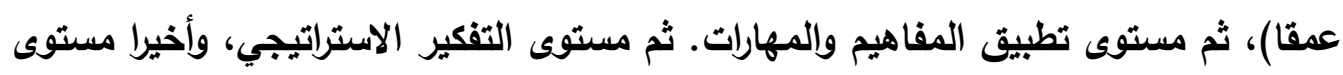

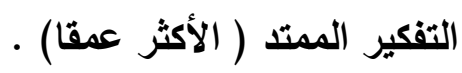
يتضح مما سبق من تعريفات لمستويات عمث المعرفة أنها تركز بشكل أساسى علي قياس استيعاب الطلاب للمفاهيم والمعلومات، وتنظيمها ويناؤها باستخدام العديد من الروابط تيط المنطقية بين الأفكار، وترسيخها في البنية المعرفية وتطبيقها فى المواقف الجديدة .

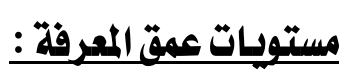

ويستند نموذج عمق المعرفة الرياعي لويب Webb) على افتراض أن عناصر

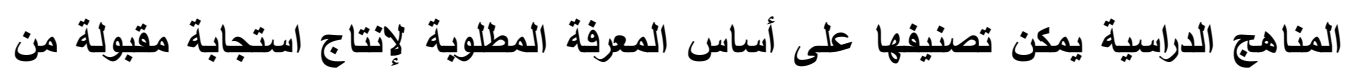
الطلاب( Mississippi State University,2009) ، وتتمثل مستويات عمق المعرفة

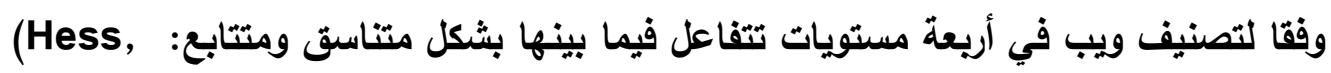

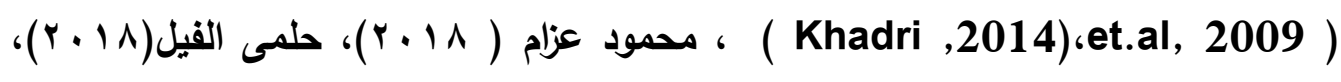

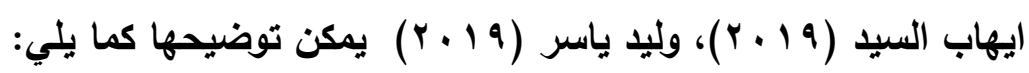


1 - مستوى التذكر وإعادة الإنتاج Recall and Reproduction

يتطلب هذا المستوى المهمات الأساسية مثل تذكر المفاهيم أو الحقائق أو المبادئ

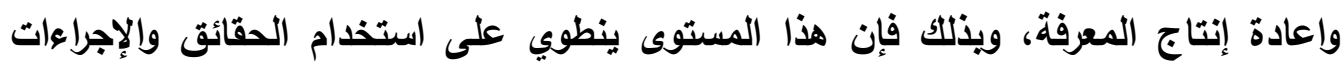

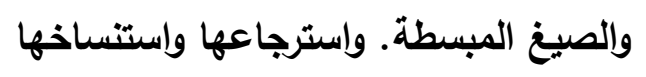

r- مستوى تطبيق المفاهيم والمهارات Basic Application of Concepts and Skills

وفي هذا المستوى يقوم الطالب بإجراء عمليات أعمق على المطومات كأن يفسر هذه

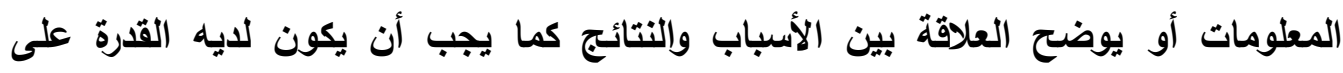

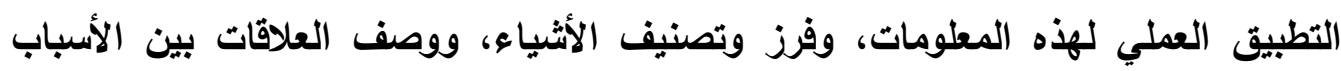

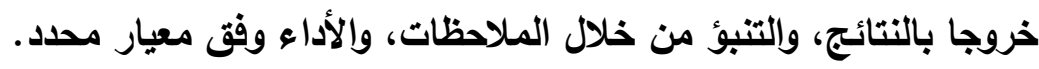

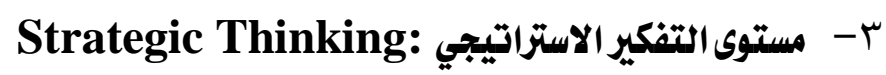
يعد هذا المستوى أعمق من المستويين السابقين حيث يتطلب استخام عمليات تفكير

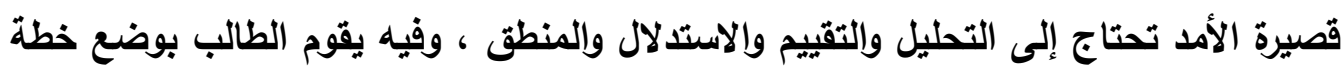
محددة لحل المشكلات التي تواجهه سواء كانت مشكلات تقليدية أوغير تقليدية من خلال تنسيق المعارف والمهارات، مما يتطلب منه مستويات عليا من التفكير مثل التحليل، والتركيب، والتقييم والتتبؤ بالنتائج، ودعم ذلك بتقديم الأمثلة والأدلة.

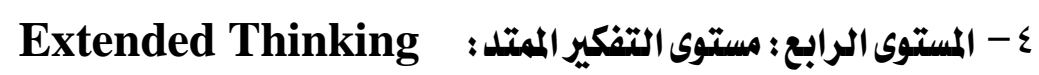
يعد هذا المستوى هو قمة مستويات نموذج عمق المعرفة ـ حيث يقوم الطالب فيه باستخام عمليات التفكير بشكل موسع، لتتفيذ الأنثطة العقلية المركبة والمعقدة، وتحليل

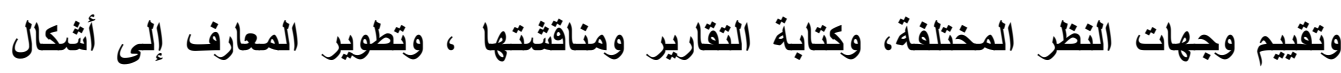
جليدة متنوعة، ووضع خطط وسيناريوهات لحل المشكلات من خلال تطبيق المهارات التي اكتسبها في المواقف الحياتية.

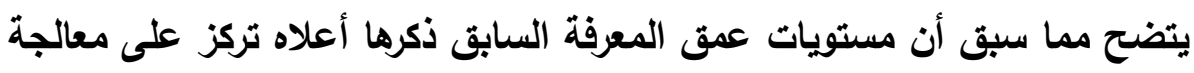
المعارف من خلال ريط المعرفة الجديدة التي يكتسبها الطالب بالمعارف السابقة لديه،

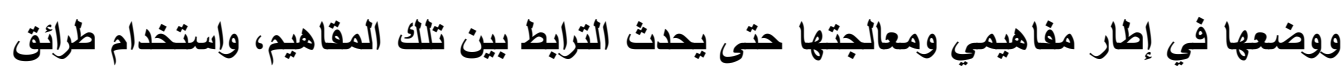

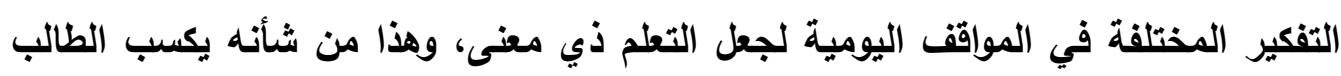


القدرة على الاستقصاء والتحليل والتقويم والتمييز والمقارنة وطرح الأسئلة وفهم الأفكار المتتاقضة، وتفسير المعلومات بعمق وموضوعية أكثر، وتطبيق المعرفة المكتسبة في مواقف

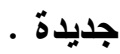

أهمية تتمية مستويات عمق المعرفة تحظى تتمية عمق المعرفة بأهمية كبيرة في العملية التعليمية، ويالرجوع للأدبيات

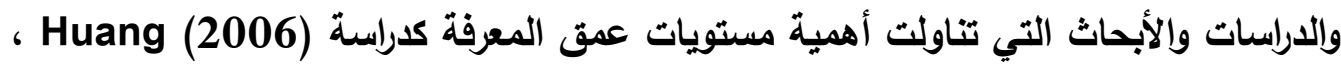

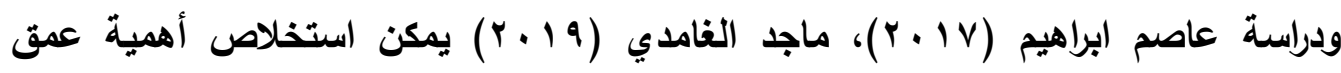

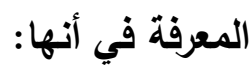
- - تساعد الطالب على ربط معارفه ومهاراته وأفكاره السابقة بخيرات جديدة ذات صلة بالحياة الواقعية. - تنمي مهارات التفكير الاستدلالي والتفكير المنطقي والتأملي وغيره من أنواع التفكير التي يحتاجها الطالب لتعميق معرفته . - - تنمي القدرة لاى الطالب على التبؤ واتخاذ القرار والاندماج والتركيز بشكل أكبر في بيئة التعلم. - - استخدام أساليب وعمليات تنظيمية أثناء التعلم · -

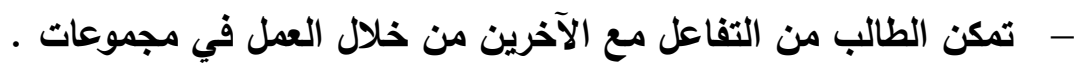
- - تنظيم المواقف التعليمية بحيث تثير تفكير الطلاب مما يتيح له تكوين بنيته المعرفية. - - تنمية مهارات حل المشكلات واتخاذ القرارات للتكيف مع البيئة المحيطة. - - اكتساب مهارة ربط الأفكار ببعضها في ضوء روئية شاملة ومتكاملة.

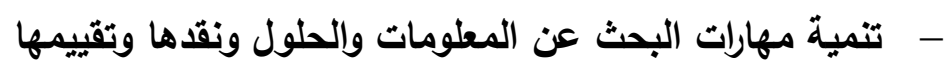
- - تنمية مستوى التفكير الاستراتيجي والممتد لدى الطالب بما ينعكس على تفكيره المستقبلي

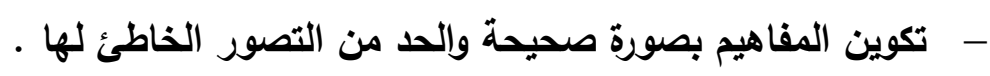

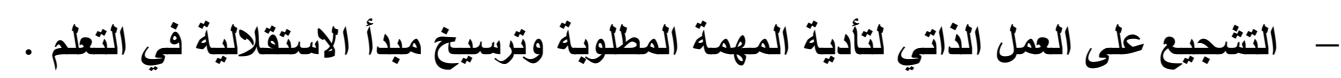
ونظرًا لأهمية مستويات عمق المعرفة فقدا سعت علديد من الدراسات والبحوث السابقة

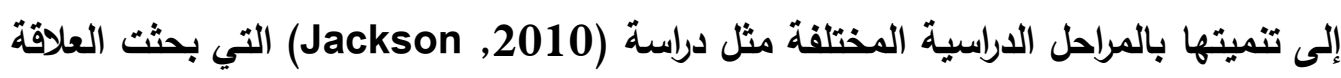

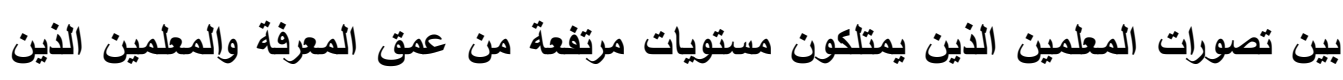


يمتلكون مستويات منخفضة من عمق المعرفة كمنبئ لتحصيل طلابهم، و دراسة (Boyles,2016)

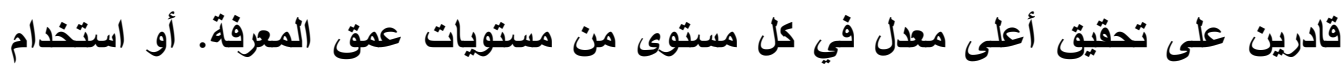

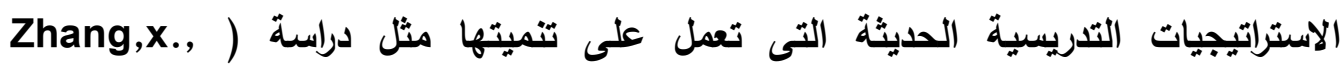

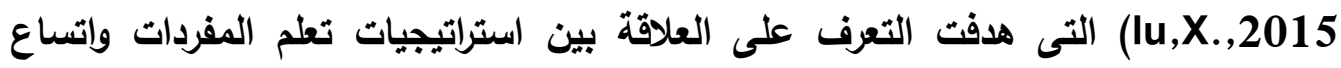

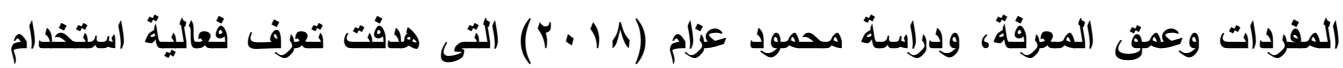
استراتيجية عظم السمك في تدريس البيولوجي لطلاب الصف الثاني الثانوي في تنمية عمق

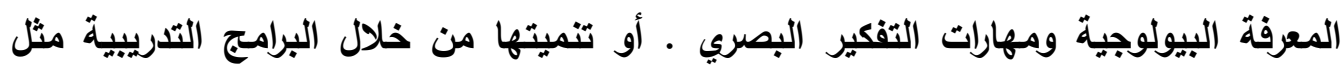

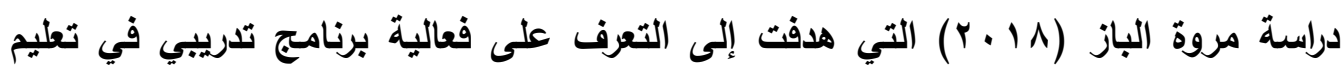
لتمية عمق المعرفة والممارسات التدريسية والتفكير التصميمي على عينة تكونت

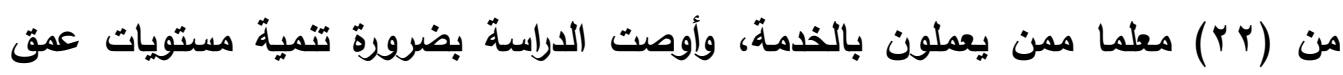

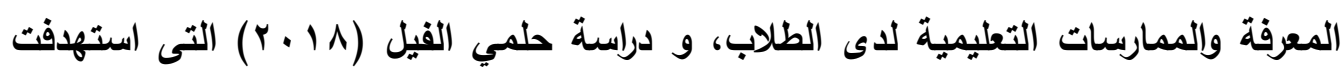

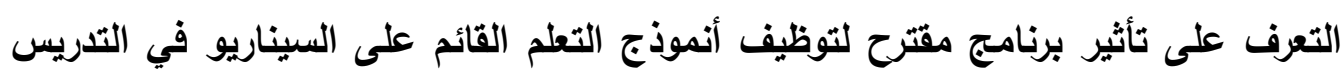

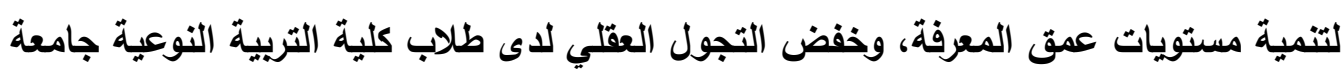

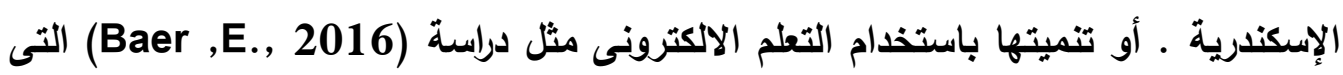

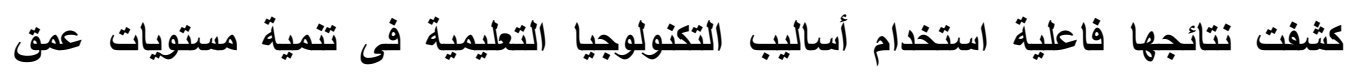

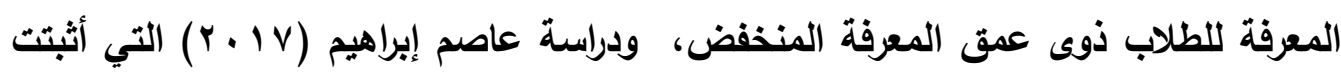

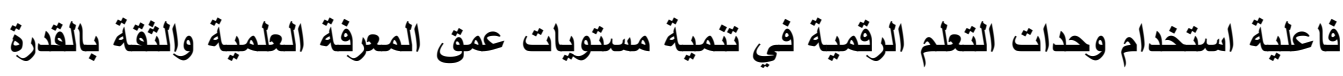

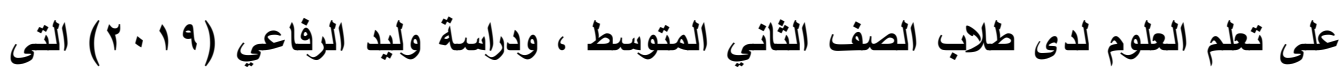
أسفرت نتائجها فاعلية تطبيق نموذج التلمذة المعرفية من خلال بيئة التعلم الإكترونية الصفية

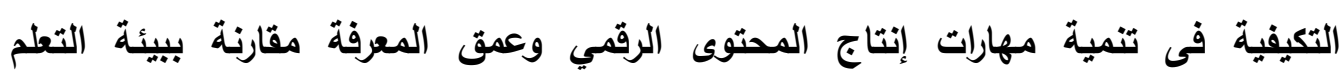

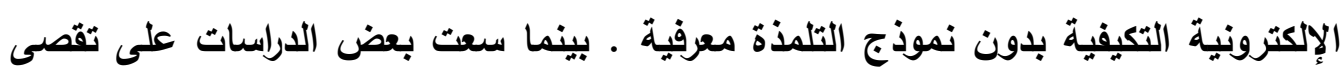
مدى تضمين مستويات عمق المعرفة بالمقررات الدراسية مثل دراسة عبد الرحمن شاهين الإنين

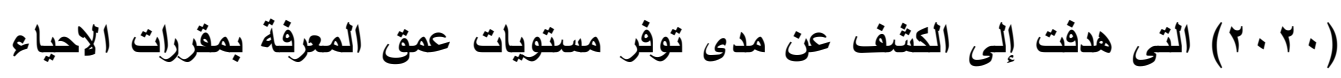

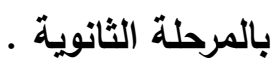


فحى ضوء الدراسات السابقة المشار البها سلفًا أمكن استخلاص ما بليى ؛

- - أكلت الدراسات السابقة على أهمية اكتساب مستويات عمث المعرفة ، وضرورتها لجميع المتعلمين

- - استخدمت بعض هذه الدراسات استراتيجيات تعلم مختلفة لتنمية مستويات عمق المعرفة

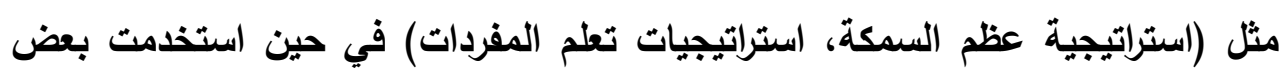

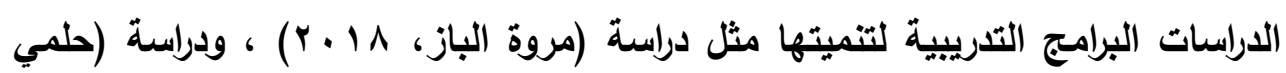

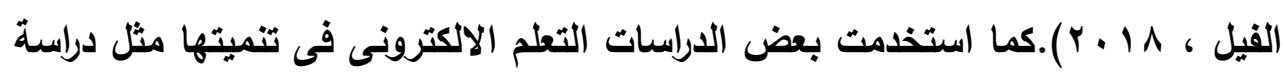

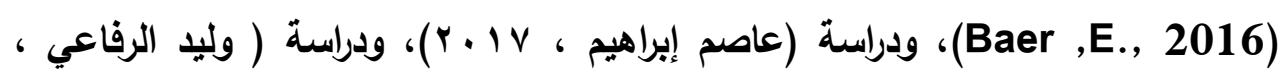
$\cdot(r \cdot 19$

فى ضوء ما تم عرضه من الدراسات السابقة بمحاورها المختلفة فى توضيح لأهمية تنمية مستويات عمق المعرفة ـ تتفق الباحثتان مع هذه الدراسات على أهمية تنميتها للطلاب الهاب المعلمين من خلال مقرر تقييم تريوي للوصول الي أقصي درجات الفهم، وستمكنهم من ريط مليط المفاهيم والمهارات الجديدة التي تم اكتسابها ومعالجتها وتخزينها في الذاكرة ثم استخدامها تمهي وتطبيقها بمواقف التدريس المختلفة. والذي ينعكس بدوره علي ادائهم التدريسي المرتبط بتطبيق ما تم تعلمه من خلال مقرر تقييم تريوي . Competencies Evaluation المحور الثالث : جدارات التقوبمي مبرن

مفهوم جدارات التقويه:

يمكن تحديد مفهوم جدارات التقويم في ضوء المعني الاصطلاحي للجدارة فمن التعريفات اللغوية لمصطلح الجدارة في قواميس ومعاجم اللغة العربية جاعت مرادفة لمعاني الاستحقاق والأهلية والتفوق، وكما جاء معني كلمة الجدارة في اللغة الاتجليزية بمعاني عديدة هي: الكفاعة، وإلمهارة ، والاقتدار، والخبرة .

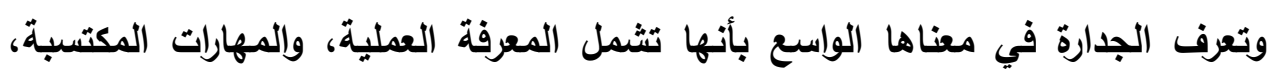

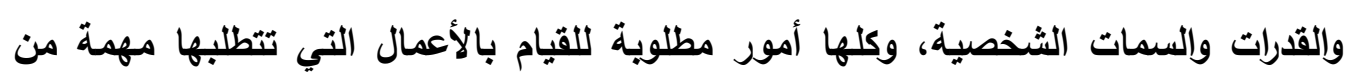
المهام، أو وظيفة من الوظائف، ويعرفها (Filani, 2010) بأنها: مجموعة من العمليات المنظمة لاستمرار اكتساب المعارف والمهارات والقيم والاتجاهات لتطوير الاداء، ويري علاء

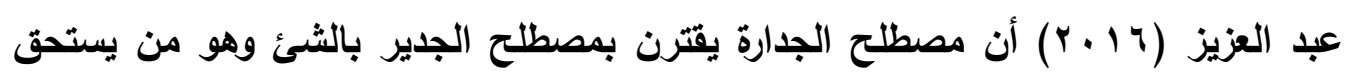




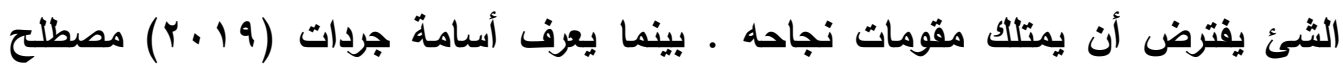
الجدارة بأنه القدرة علي الأداء بكفاءة عالية، وكذلك القدرة علي الاستجابة للتغيرات المختلفة.

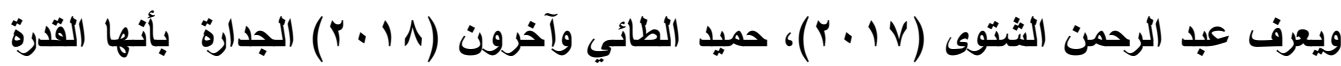
على أداء الأعمال الموكلة للفرد وفق المستويات المحددة، بالكفاءة والفعالية المطلوية . . وتعرف الجدارات التقويمية بأنها: مجموعة من المعارف والمفاهيم والمهارات التي توجه سلوك المعلم، من أجل قيامه بعملية تقويم الطلبة وتساعده في أداء عمله بمستوى معين من ون

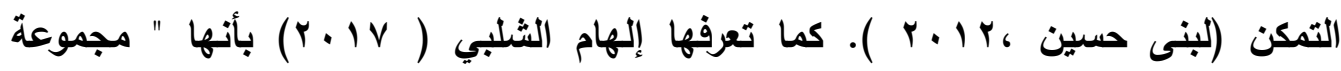
الصفات الثخصية أو المهارات أو السلوكيات أو المعارف التي يتمتع بها المعلم في مجال

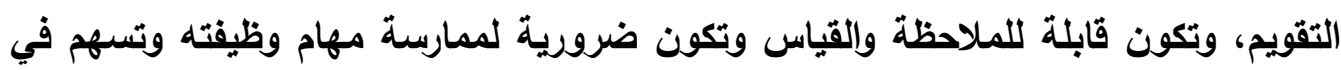

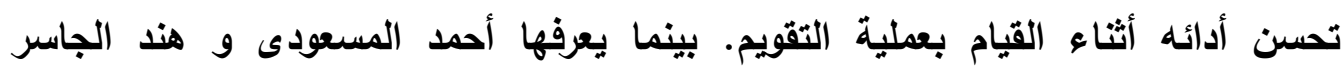

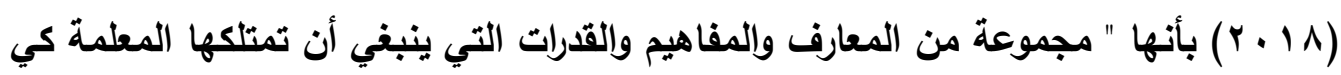

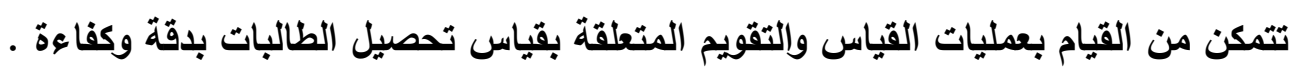
من التعريفات السابقة يتضح أن جدارات التقويم تعنى توظيف المعلم لمجموعة المهارات

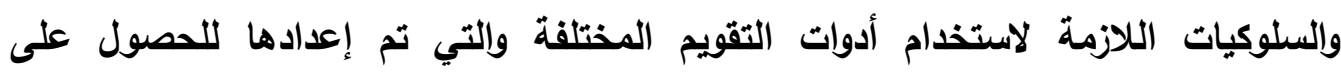

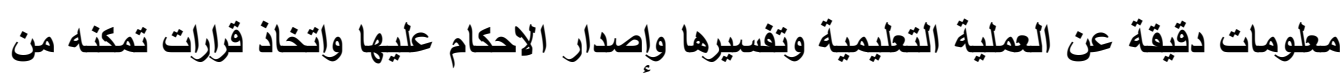
تحسين أدائه التدريسى.

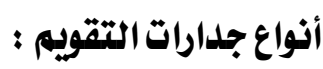

صنف الباحثون جدارات التقويم إلى ما يلى:( عبد الباقى أبو زيد و محمد سعد

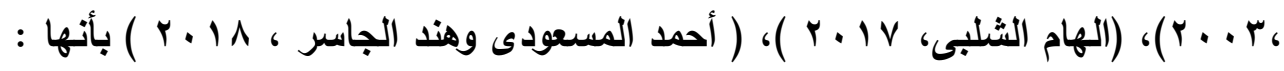
أولاً: الجدارات الخاصة بالتخطيط ويناء أدوات التقويم: تثنتمل هذه الجدارات الجدات علي تحديد أهداف التقويم وتحديد المفاهيم التي يراد تقويمها، واختيار أدوات وأساليب التقويم التي

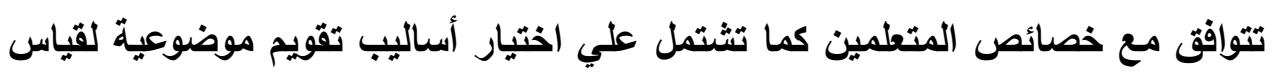

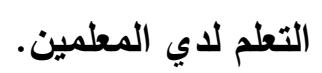
ثانياً: الجدارات الخاصة بالتطبيق والتنفيذ: تثتمل هذه الجدارات علي استخدام أساليب تقويم متنوعة، وتطبقها في الوقت المناسب، واستخدام جميع أنواع التقويم (مبئي، تكويني، ختامي)، كذلك استثمار التقويم في اثارة دافعية المتعلمين أثناء التدريس. 
ثالثاً: الجدارات الخاصة بتفسير وتحليل النتائج: تثتمل هذه الجدارات علي الالتزام بالموضوعية في استخراج نتائج التقويم، وكتابة تقارير، واستخدام محتوي ملف الانجاز، واستخدام نتائج دراسات علمية لتفسير نتائج تقويم المتعلمين. ونظراً لأهمية جدارات التقويم في برنامج إعداد الطالب - المعلم والتى تعد مقياس نجاح

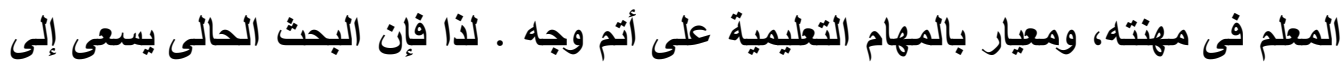
تنمية تلك الجدارات والتى يحتاجها الطالب - معلم الاقتصاد المنزلى فى الموقف التدريسى لته بهدف الوصول إلى مستوى الإتقان والفاعلية. وذلك من خلال التدريب على ممارسة تلك الك الجدارات أثناء قيامه بالتدريس الفعلى بالتدريب الميدانى. أهمية تنمية جدارات التقويم : إن الهدف الأساسي من تنمية جدارات التقويم كما حدها: ( النور أحمد و عبد الرحمن

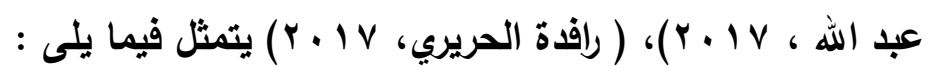

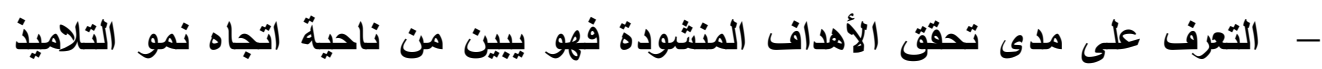
ومداه، ومن ناحية أخرى مدى نجاح المعلم في عمله ومدى قدرته على التتويع في من في التهن استخدام طرق التدريس الفاعلة والأنشطة المصاحبة والتوسائل وأدوات التقويم المختلفة. - - يقدم حلولا مناسبة للصعويات التي يواجهها كل من المعلم والمتعلم والبرامج والمنهج. - - يساعد التقويم في تحفيز التلاميذ على التعلم لأنه يمدهم بمعلومات حول نقاط ضعفه ئهم وقوتهم. - المساعدة في تدريب المتعلم على تقويم الأمور والحكم على نفسه ومعرفة اتجاهاته وميوله وقدراته ومدى تحقيقه لأهدافه التي يرسمها في حياته بشكل عام. - - الكشف عن مدى فاعلية الاعداد التريوي و البرامج التربوية والتعليمية. - - الحصول على معلومات وإحصائيات تتعلق بمدى الانجازات والأوضاع الراهنة لرفع تقارير إلى المسئولين أو أولياء الأمور • - تساعد المعلمون علي تحسين الأداء التدريسي وتنميته باستمرار من خلال التظذية الراجعة المقدمة لهم بعد تحليل وتفسير نتائج التقويم التي يستخدمونها أثناء العملية التدريسية 
ونظرًا لأهمية جدارات التقويم التى تعد ركنًا أساسيًا من أركان العملية التدريسية ونقطة البدء لإحداث الإصلاح في الجواتب الأخرى للعملية التعليمية فقد اهتمت دراسات ويحوث عدة التهات علي تنميتها ومنها دراسة كل من :

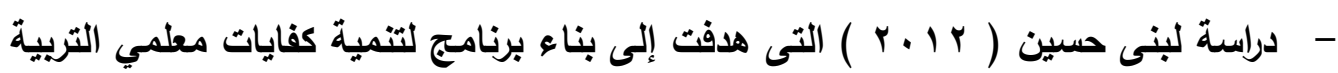
الرياضية في مجال القياس والتقويم بناء على حاجاتهم التدريبية، وقد أشارت نتائج هذه الدراسة إلى أن هنالك عدة عوامل متصلة بالقياس والتقويم ليراعيها معلمو التربية الرياضية عند قيامهم بأدوارهم المهنية كان من أبرزها: الترابط والتكامل بين المعارف التي عولهي تدور حولها أداة التقويم، كما أظهرت النتائج محدودية في الممارسات الخاصة بادئ بالقياس التراس

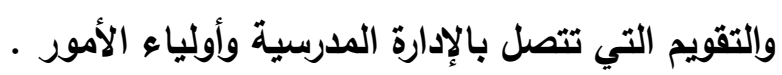
- دراسة ( Matsenjwa,2013) التى هدفت الكثف عن مهارتى معلى المعلى المرحلة

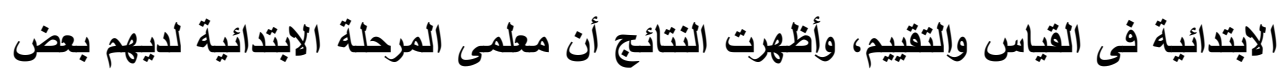
المعرفة فى القياس والتقييم الا أن المهارات تتقصهم فى استخدام أساليب التقييم المختلفة وأوصت الدراسة بضرورة تدريب المعلمين فى الكليات والجامعات على ممارسة أساليب القياس والتقييم. - مراسة (Ozzdemir,2013) التى استهدفت البحث عن الكفايات التدريسية لمعلم المرحلة الأساسية وحاجات التدريب على أدوات القياس والتقييم أثناء الخدمة ـ وأظهرت النتائج أن المعلمين لايهم مستويات كفاءة متدنية فى بعض أدوات التقييم، وأوصت بضرورة توفير برامج تدريبية للمعلمين أثناء الخدمة حول استخدام أساليب القياس والتقييم

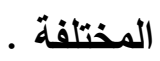

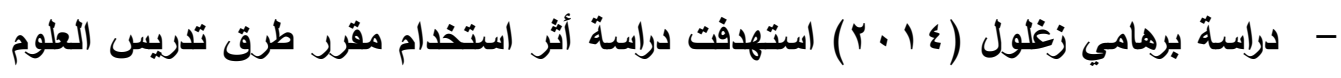
التجارية الاكتروني في تنمية المعارف وجدارات التقويم لدي طلاب شعبة التعليم التجاري بكلية التربية. وأظهرت النتائج فعالية مقرر طرق تدريس العلوم التجارية الاكتروني في في وجية تعليم وتعلم الطالب المعلم للمعارف المرتبطة بجدارات التدريس بالإضافة الي اكتسابه

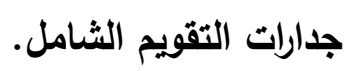
- دراسة علي الكساب، موسى الثقيفي (7 1 ـ ب) التى هدفت التعرف على مدى ممارسة

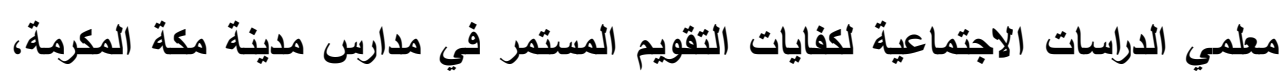


اشتمل مجتمع الدراسة على جميع معلمي مرحلتي الثانوية والمتوسطة في إدارة التربية

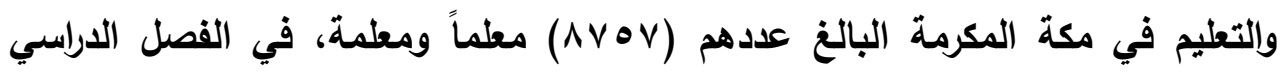

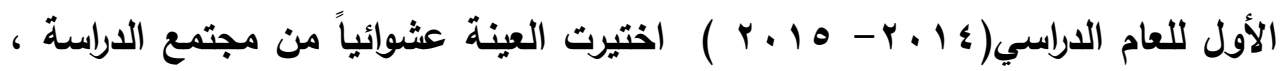

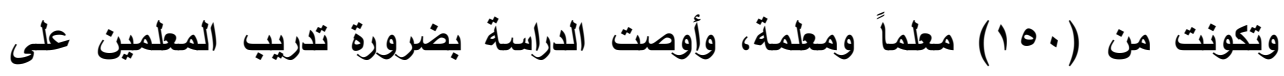

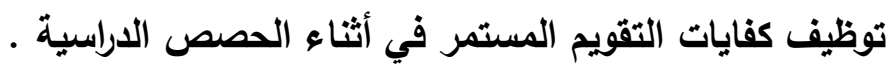
- دراسة (Koloi,2016) بغوان التريب على التقييم شرط مسبق لكفاءات المدرسين

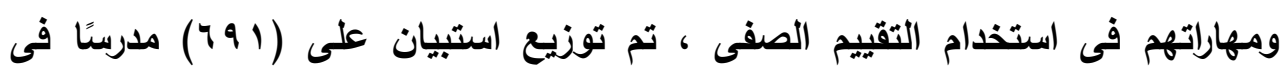
الددارس الحكومية الأساسية و الثانوية فى بتسوانا لتحديد العلاقة بين مستوى التدريب

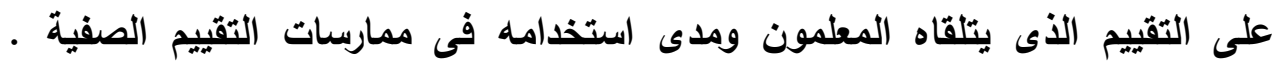

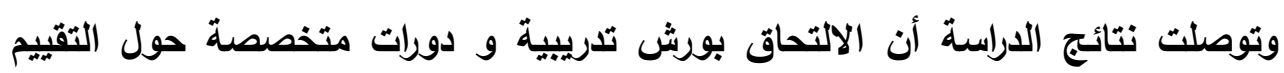
خلال الخدمة كان له علاقة مهمة باستخدام المعلمين وسائل التقييم الصفية ، وأوصت التيت الاراسة على ضرورة التركيز على بناء كفاءة المعلمين فى التقييم .

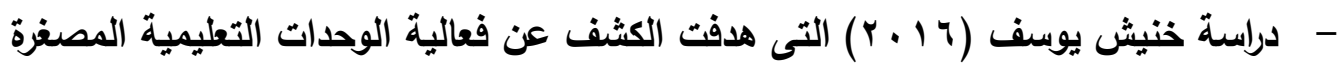
في تطوير كفايات التقويم لاى معلم المرحلة الابتدائية استنادا على احتياجاتهم في مجال

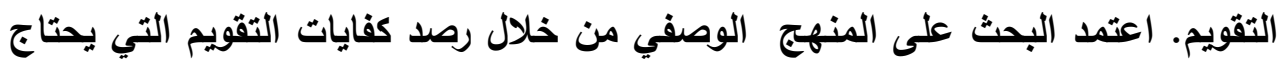

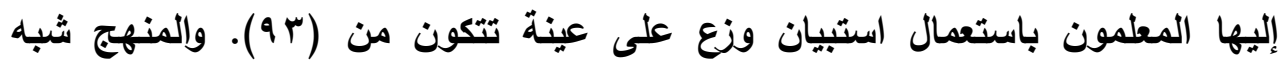

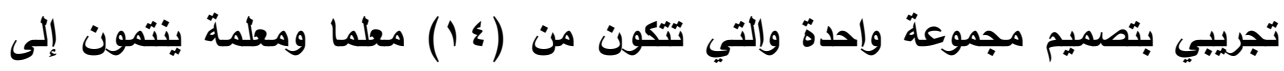
مجتمع البحث، حيث استفادت العينة من الوحدات التعليمية المصغرة وخضعت لقياس قبلي ويعدي بالاعتماد على اختيار موضوعي من نوع الاختيار من المتعدد. وكثفت

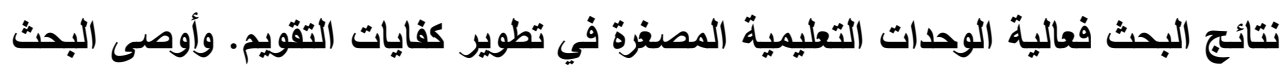
بأهمية تدريب المعلمين وفقا لاحتياجاتهم وأساليب قائمة على الكفايات التقويمية .

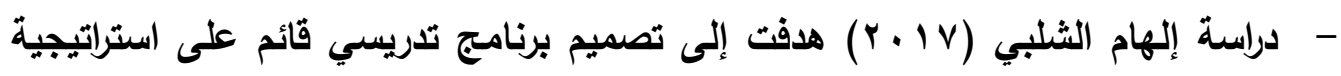

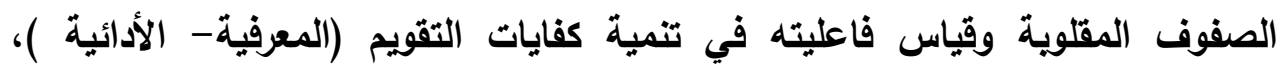
وعادات العقل لاى الطالبة/ المعلمة في جامعة الإمام محمد بن سعود الإسلامية. وأظهرت النتائج فاعلية البرنامج في تنمية كفايات التقويم، وعادات العقل، وأوصت التعاد 
الدراسة بضرورة تدريب المعلمين وتثثيعهم على استخدام كفايات التقويم المختلفة مما يزيد من فاعلية العملية التعليمية.

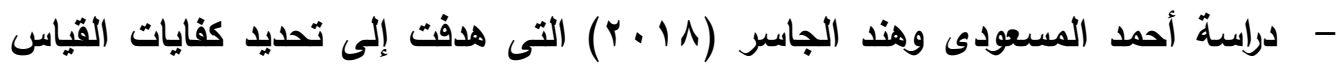
وإلتقويم لاى معلمة التعليم العام بتبوك وفق المعايير العالمية في ضوء بعض المتغيرات. وقد أوصت الدراسة إلى ضرورة تدريب المعلمات لتحسين كفاءتها في القياس والتقويم.

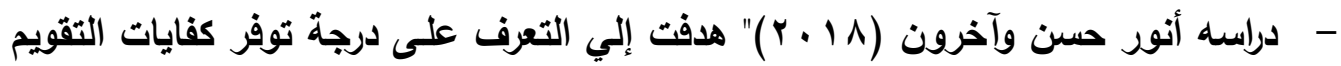
لاي معلمات رياض الأطفال لمادة الرياضيات تبغا لمتفيرات المنطقة التعليمية وسنوات

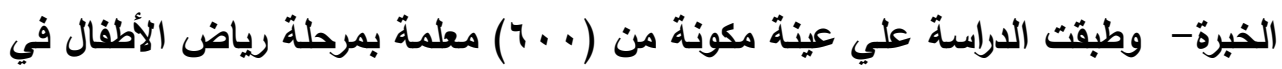
جميع المناطق التعليمية الست بدولة الكويت، وقد أوضحت الدراسة بضرورة اعداد الطلاب المعلمين علي استخدام النماذج التعليمية واستخدام المستحدثات التكنولوجية لتنمية الكفايات التقويم. فى ضوء ما سبق عرضه من الدراسات والبحوث التريوية التى اهتمت بتنمية جدارات التقويم أمكن استخلاص ما يلى : - أكلات معظم الاراسات والبحوث على أهمية تدريب المعلمين على ممارسة أساليب التقييم المختلفة وتحديدها بطريقة علمية، والعمل على تتميتها من خلال البرامج التدريبية وورش العمل المتخصصة - اعتمدت الدراسات السابقة على طرق مختلفة وأساليب متعددة لتنمية جدارات التقويم. فقد

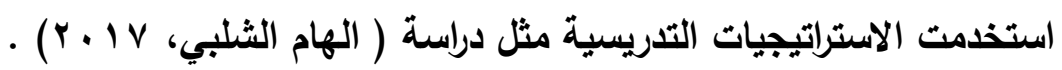

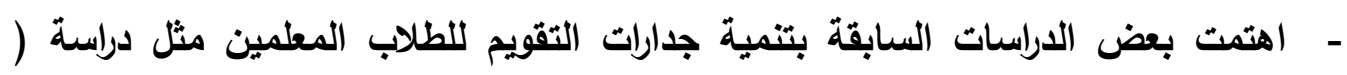

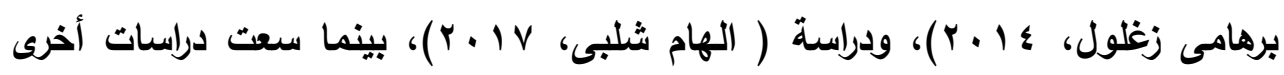

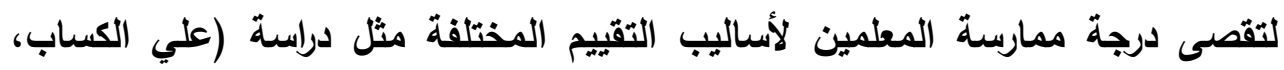

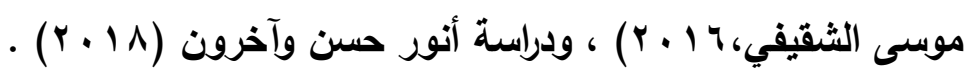
يتضح مما سبق ضرورة الاهتمام بتنمية جدارات التقويم للطلاب معلمى الاقتصاد المنزبي حيث تزودهم بالمعارف والخبرات والمهارات والتى بدورها تمكنهم من وضع أهداف واقعية وتحديد النتاجات التي يتوقع من الطالب تحقيقها ويالتالي التخطيط لبناء أدوات التقويم

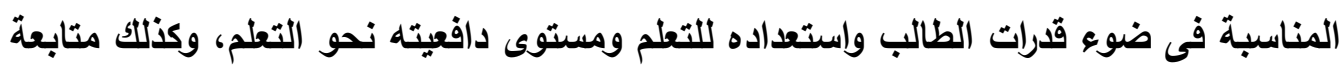


انجاز الطالب الأكاديمي وتقدمه الدراسي وما تحقق من الأهداف التعليمية، ويالتالي يمكن اكتثاف صعويات التعلم وتحديد نقاط الضعف من خلال تحليل وتفسير نتائج عملية التقويم

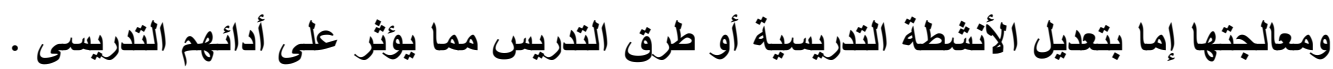

\section{المحور الرابع : توكيد الدات المهنية}

يُعد توكيد الذات من أبرز المفاهيم التي تعبر عن شخصية الفرد أثناء عمله، ومن أهم العوامل التي تؤثر في سلوكه الاجتماعي وتوافقه النفسي والاجتماعي ، ويشير ( أحمد عبد اللطيف ، لمياء الهواري ، ^ . . ؟ الي مفهوم الذات المهنية بأنها الصورة التي يكونها الفرد عن ذاته في مجال عمله ، وهذا المفهوم يتطور وينمو في ضوء خبراته الحياتية المرتبطة

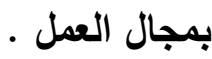

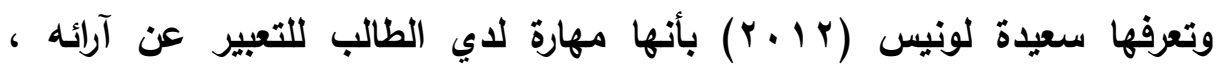
والإفصاح عن مشاعره الايجابية والسلبية بطريقة ملائمة ، والمبادأة والاستمرار في العلاقات الاجتماعية بصورة ايجابية ، مع الالتزام بالقيم والمعايير الاجتماعية والأخلاقية . كما يعرفها علي سليمان (Y. V Pأنها القدرة علي التعبير الموضوعي عن المشاعر والأفكار والآراء والقيم والمعتقات والطموحات المستقبلية المرتبطة بمهنة التدريس ليؤكد ثقته بذاته واعتزازه بها ـ

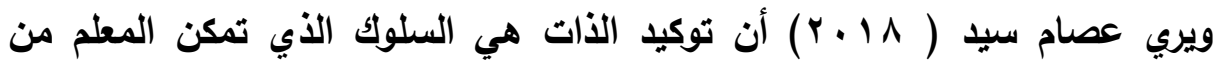
التصرف الصحيح حيال المواقف التي قد يتعرض لها داخل البيئة التعليمية ، لمساعدة عن التعبير عما يجول بخاطره بصدق ، وينال حقوق دون إنكار حقوق الآخرين ، ويفي باحتياجاته النفسية . وتتضمن توكيد الذات المهنية مجموعة من السلوكيات التي يمكن اكتسابها وتعلمها واستيعابها وادخلها من اتجاهات لفظية وغير لفظية بالاتصال مع الآخرين ، لزيادة تقوية الثخصية وتعزيز الثقة بالنفس في مجال عمله ، واقامة علاقات اجتماعية بصورة إيجابية. 


\section{خصائص توكيد الذات المهنية:}

تتسم توكيد الذات المهنية بمجموعه من الخصائص منها :

1 - تزيد من قرة الفرد في التعبير عن المشاعر بحرية والدفاع عن الحقوق الخاصة

وممارستها بطلاقة.

r - تنمي لاي الفرد احترام آراء الاخرين وتقبل الرأي والرأي الاخر اثناء العمل .

r- فعاليتها نسبية تتوقف علي المعايير المستخدمه ، وإدراك الثقة المغزى للسلوك .

ع - تتصف بأنها موققيه تعتمد علي المتغيرات التي تساهم في تثكيلة علي مستوي الفرد أو

من خلال التفاعل مع الآخرين - ماتص

ه- قابله للتعلم :اي امكانية تعليمة بطريقة نظامية أو بطريقة ذاتية من خلال الخبرة

Lera A. , 2016) والتفاعل الاجتماعي الذي تكسبه الخبرة .وهذا ما أكلته دراسة

(Kamalova

צ- تتضمن عناصر لفظية وغير لفظية : اللفظي يقاس من خلال التقرير الأتي ، أم الغير

لفظي فيتضمن الايماءات والحركات والإشارات .

مظاهر توكيد الذات المهنية :

تنقسم مظاهر توكبد الذات المهنية الي ثلاث مظاهر هما :

• مظاهر غير لفظية :وتنقسم الي قسمين :

• مظاهر سلوكية داخلية : تثبير الي العمليات الفيزيولوجيه كالنبض وضغط الدم . • مظاهر سلوكية خارجية :تعبر عن التقاء العيون، والابتسام ، ومدة الاستجابة ، وشدة

$$
\text { الصوت ، وارتباك الكلام ، وتعبيرات الوجه ( (ابراهيم الفقي ، . . . ب) }
$$

• م مظاهر لفظية توكيديه :تتمثل في التوكيد الاجتماعي والدفاع عن الحقوق ، والقدرة العامه علي التعبير ، والقدرة علي التعبير عن الآراء ، والتصرف مع الاشخاص المختلفين ،

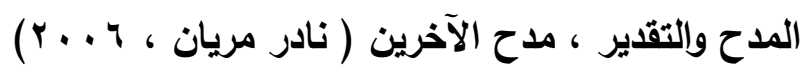


•. اتخاذ القرار :عملية فكرية ، سلوكية ، معقدة ، تتضمن السعي لوضع بدائل ، ثم اختيار البديل المناسب ضمن استراتيجيات مناسبة للوصول للهذف المرغوب ( صلاح الخولي ،

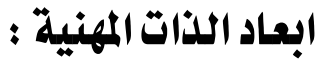

ولقد أكلت العديد من الدراسات ومنها ( علي سليمان ، Y + Y) ودراسة ( محمود

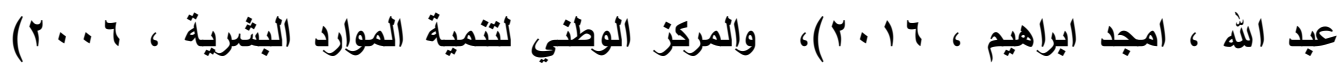
تتضمن الأت المهنية من عدة ابعاد تثكل ملامحها وخصائصها ، وتلك الابعاد هي : 1 - البعد المعرفي : يتضمن المعارف والمفاهيم والمعلومات التي تتطق بمهنة التدريس والتي تساعده علي اداعه عمله المهني بكفاءة. ץ - البعد النفسي : تثثير الي مدي وعي المطلم مشاعره واهتماته وقدرته علي قراءة مشاعر الآخرين والتفاعل معهم بمرونه والتحكم في إنفعالاته وسماته الثخصية لتمكنه من

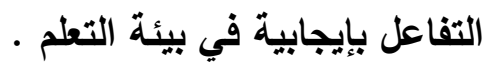
r- البعد الأدائي المهني : تعبر عن الاداءات والممارسات المهارية التي يمارسها الفرد اثثاء

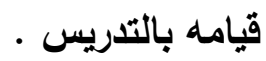
ع - البعد الاجتماعي :يتعلق بالسمات الثخصية والاجتماعية التي يجب ان يتسم بها اثثاء عملية التدريس مثل الاتزان الانفعالي والمبادأة واتخاذ القررات والتمتع بالعلاقات الانسانية المرونة والقدرة علي التكيف مع التغيرات الاجتماعية . ه- البعد القيمي : يسمي بإخلاقات المهنة وتعبر عن المتقدات والاتجاهات والدوافع والافكار والمبادئ والمعتقات التي تظهر في صورة سلوكيات ومهارات اثثاء ممارسة المهنة. צ- البعد المستقبلي : وممكن ان نسمية الطموح المهني حيث يشير الي الاهداف التي يضعها الفرد لنفسه في مجال عمله ويسعي لتحقيقها للنهوض بعطله . مما سبق نجد أن توكيد الذات المهنية بابعاده المختلفة تعتبر مكون اساسي في بعاي تكوين شخصية المطلم الناجح السوي المتكامل ، القادر علي الاعتزاز بنفسه وجدير بمهنته 
التدريسية والايمان بأهميتها في اعداد نشئ متميز، كما تعزز لاية القدرة علي الاستقلال وضبط النفس والقدرة علي مواجهة المشاكل والسرعة في اتخاذ القرارات الصحيحة .وهذا ما أكلت العديد من الاراسات ومنها :

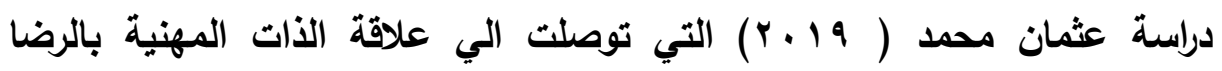
الوظيفي لاي المرشدين النفسيين في المدارس الثانوية بولاية الخرطوم •

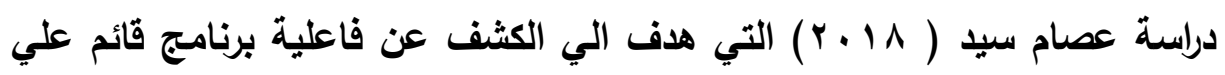
التدريب المصغر والتعلم المستند علي الدماغ في تنمية مهارات التفكير العلمي ومهارت تدريسية وتوكيد الذات المهنية لدي معلمي العلوم قبل الخدمة واسفرت النتائج علي فاعلية البرامج في تنمية التوكيد الذات المهنية وأوصت أهمية اعداد البرامج التي تهدف الي تنمية توكيد الذات لاي المعلمين قبل الخدمة .

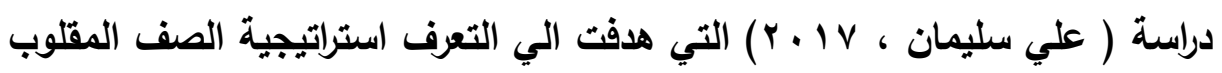
في تنمية المهارات التدريسية وتوكيد الذات الهنية لدي الطلاب المعلمين واوصت بضرروة تنمية توكيد الذات المهنية لاي المعملين كاحد مقومات الثخصية المهنية للطالب المعلم واساس لمتطلبات النجاح المهني المستقبلي . دراسة (محمود عبد الله ، أمجد ابراهيم ، 1 ـ ـ ץ) التي توصلت الي علاقة الذات المهنية بالاستقرارا المهني لاي المرشدين التريويين. ويناء علي الاراسات السابق والادبيات العربية نجد أن توكيد الذات المهنية يتأثر بعدة عوامل منها ما هو داخلي مثل القدرات العقلية ، سماته الشخصية ، ومنها ما هو خارجي كنظرة الفرد لنفسه ، وإلتأثيرات الاسرية والخبرات المدرسية ، والمعايير الاجتماعية ، والدور الاجتماعي ، التفاعل الاجتماعي ، التأثيرات الجسمية ، البيئة المحيطة به. 
تم استخدام بعض مراسي التعلم الاكترونية ( ملحق 1 ) لتقديم المحتوي التعليمي

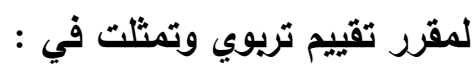
• عروض الفيديو: تم استخدام عروض الفيديو لتوضيح كيفية استخدام مهارة التقويم في

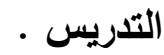

الشاء فصول افتراضيه باستخدام برنامج Class Room : لعرض المحتوي العلمي للمقرر مع وضع فيديوهات توضيحية ويعض الأثكال التخطيطية المرتبطة بالمحتوي ، مع وضع تكليفات ومهام تطبيقية للطلاب وادارة مناقشات بين الطلاب وأستاذ المادة . • تطبيق الواتس آب Watsapp : لتقديم بعض عناصر المحتوي التعليمي وتوفير الدعم والتوجيه والإرشاد والمساعدات للطلاب . • ريطة ذهنية : باستخدام برنامج XMind لتنظيم المعلومات والمفاهيم المرتبطة بمقرر تقييم تريوي - تصن

• منتديات المناقشة : لمناقشة بعض موضوعات المحتوي التعليمي ، التي تمثلت في لري مناقشات متزامنه وغير متزامنه بين الطلاب .

الانشطة التفاعلية : صممت الباحثتان مجموعة من الانشطة التفاعلية وإلمهمات التعليمية المرتبطة بأساليب التقويم المتضمنة بمقرر تقيم تربوى موزعة على موضوعات المقرر، وتم عرض هذه الأنشطة على مجموعة من السادة المتخصصين فى مجالى المناهج و طرق التدريس وعلم النفس التريوى ، وذلك للتحقق من مدى ارتباطها بموضوعات المقرر ، ومدى كفايتها فى تحقيق الأهداف المرجوة ـ وقد أظهرت نتائج التحكيم اتفاق أكثر من ^^\% من السادة المحكمين على صلاحية تلك الأنشطة التطبيقية ـ ويذلك أصبحت الأنشطة التعليمية فى صورتها النهائية ملحق (r). 


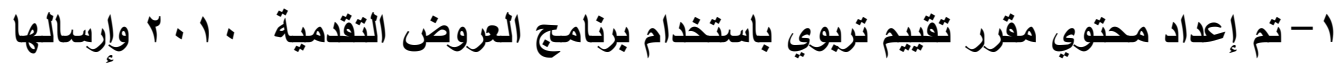
الي كل من موقع Class Room , Wats App.

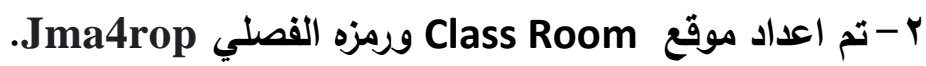

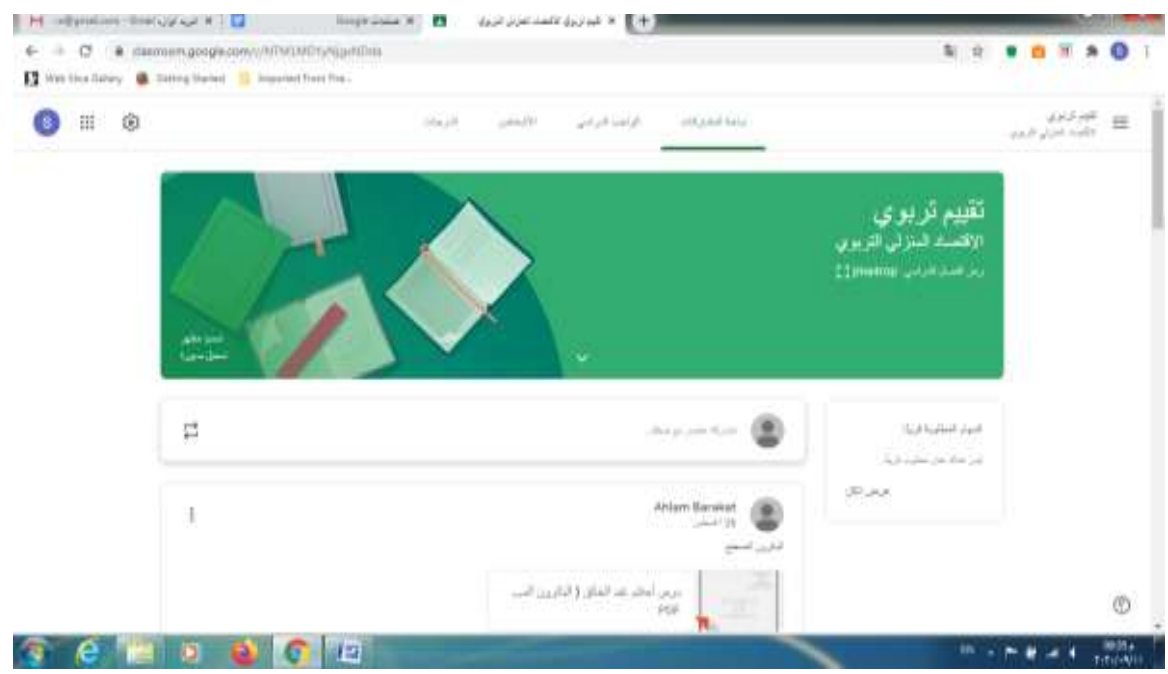

شكل ( 1 ) يوضح شكل Class Room

r-تم إعداد موقع ارشادي علي Google site والرابط الموقع https://sites.google.com/view/education-evaloution

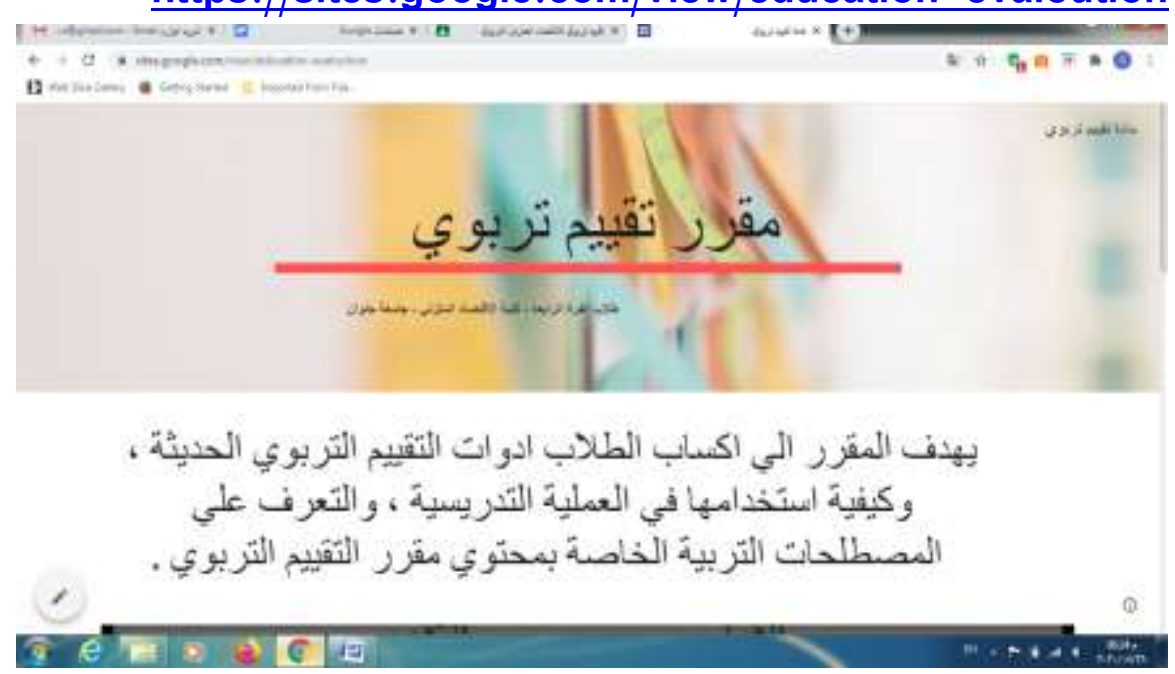

وكل (r) يوضح موقع 
(https://chat.whatsapp.com/G2weRpgHV79BcRMIToyXyd)

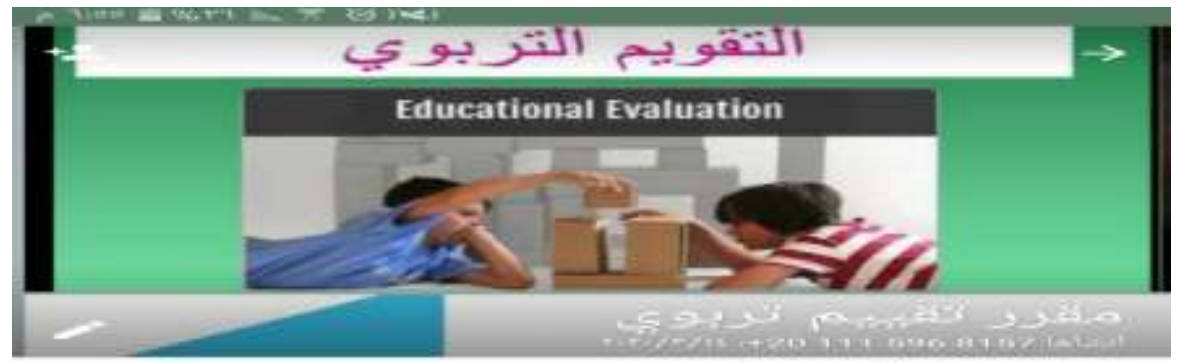

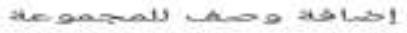

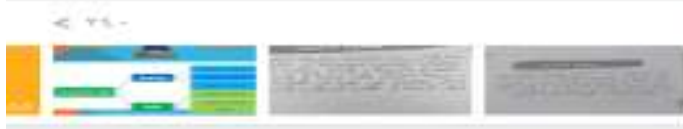

\section{Wats App شكل (r) يوضح وجهة}

هoogle تم إعداد نماذج محاكاة وتم تخزينها علي Google Drive كما تتيح أداة Drive رفع مجموعة من الصور وملفات (Word) الخاصة بإعداد وتحضير محاضرات

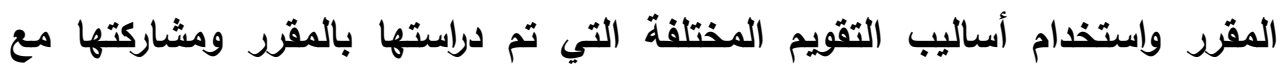
الزملاء والتعليق عليها وحفظها وتقيمها و تقديم التغذية الراجعة من جاتب الباحثتان.

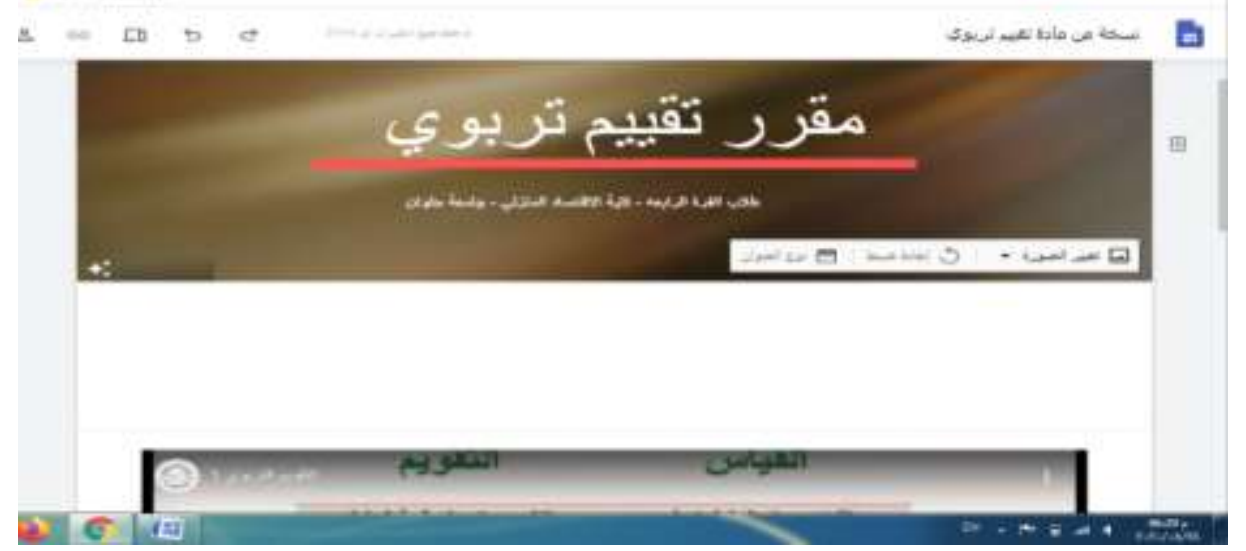

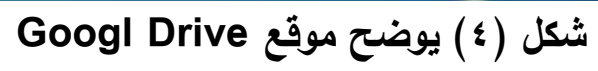

צ- تم تصميم أنشطة تفاعلية فى صورة مشكلات مفتوحة النهاية وتحميلها علي موقع بوفع

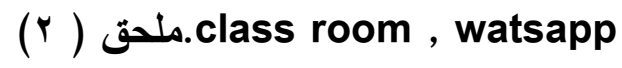


V- تم تصوير فيديوهات لبعض الطلاب أثناء القيام بشرح دروس الاقتصاد المنزلي بالتربية

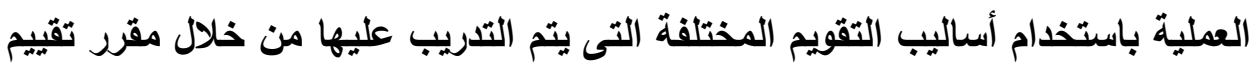

تريوى

ورفعها علي كلا من Wats App , Class Room

مر حلة التنفيذ : مرني

أ- عقب تحديد مراسي التعلم الاكترونية التي تم تقديمها من خلالها المادة العلمية الخاصة بمقرر تقييم تربوي ، تم تعريف الطلاب بالمواقع المختلفة لمراسي التعلم وإرسالها الروابط

لهم عن طريق Wats App.

ب- يشاهد الطلاب المحتوي العلمي من خلال المحاضرات التي تم ارسالها صورة بوربيونت مصاحب بصوت الدكتور لشرح المحتوي من علي موقع Class Room ومناقشتها مع الطلاب أثناء الثرح ، ومتابعه المناقثة من خلال Watsapp ، كما يتم وضع بعض هل التكليفات علي Classroom.

ت - يستطيع الطالب أن يحل التكليفات بعد الاطلاع علي بعض الفيديوهات الخاصة بموضوعات المقرر التي تم إعدادها من قبل الباحثتان وإرسالها علي Classroom ، وتنفيذ بعض الخرائط الذهنية من خلال فتح Google Drive ، كما تم ارسال فيديو توضيح للطلاب لكيفية عمل خرائط ذهنية الكترونية علي Wats App. ث- الاستعانة بالموقع الارشادي في الحصول علي معلومات إضافية من مصادر مختلفة حيث تم ارسال روابط للإطلاع خاصة بالمحاضرات علي موقع Class Room.

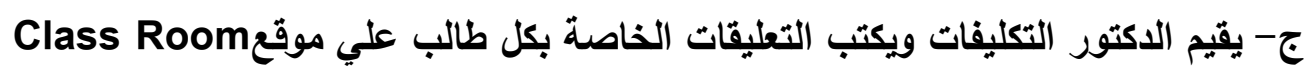
ويعطي درجه لكل تكليف .

مرحلة التقويم : بعد الانتهاء من إعداد بيئة التعلم الاكتروني القائمة علي مراسي التعلم تم

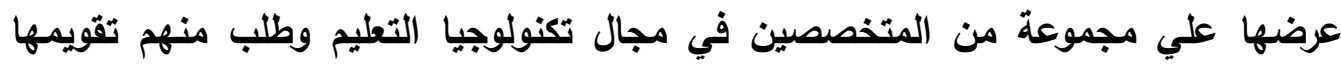
للتأكد من صلاحيتها للتطبيق علي مجموعتي البحث ، وقد مئ أبدي المحكمين موافقتهم علي فئي

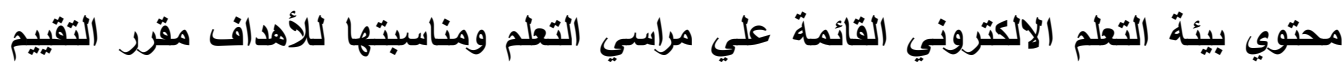

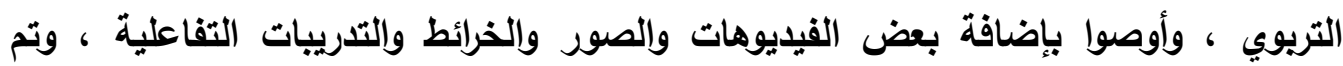

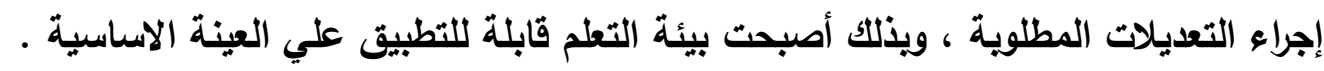




\section{1}

أ- - تحديد الهدف من الاختبار: هدف الاختبار إلى قياس عمق المعرفة المرتبطة باكتساب

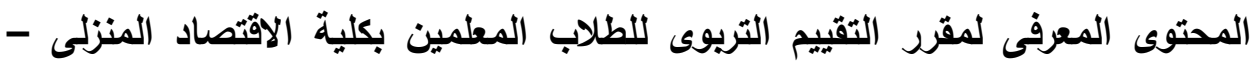

جامعة حلوان

ب- صياغة مفردات الاختبار: فى ضوء تحليل المحتوى التعليمى لمقر تقييم تريوى وفق

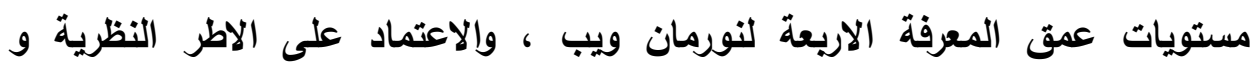

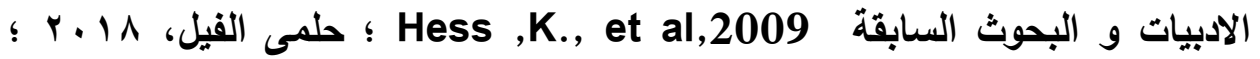

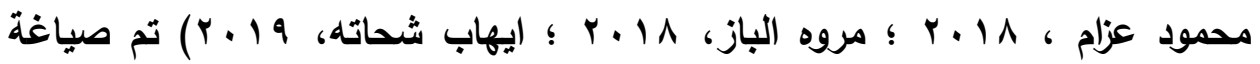
الفقرات من نوع الاختيار من متعدد في مستوى ( التذكر وإعادة الانتاج ، وتطبيق

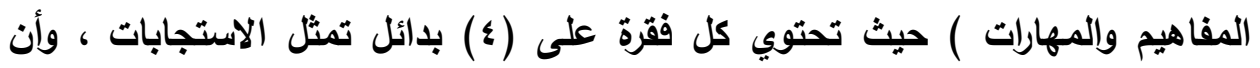

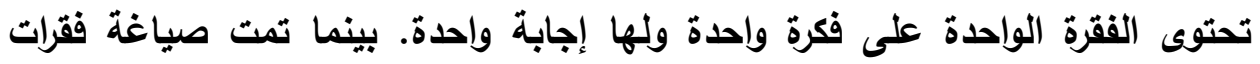

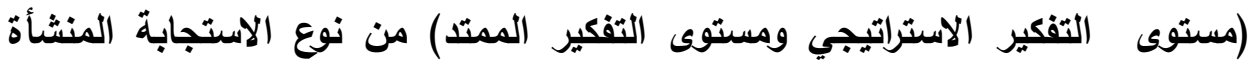
Constructed Response (CR)

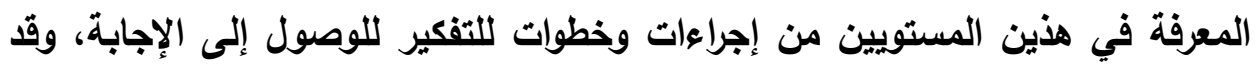
روعى عند صياغة مفردات الاختبار أن تكون أسئلة الاختبار مرتبطة بأهداف محتوى الإنهابه مقرر تقييم تريوى، والجدول التالى يوضح مواصفات اختبار عمق المعرفة و الأوزان

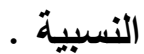




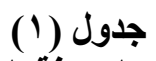

مواصفات اختبار مستويات عمق المعرفة المرتبط بمحتوى مقرر تقيم تربوى عمي

\begin{tabular}{|c|c|c|c|c|c|c|c|}
\hline \multirow[b]{2}{*}{ الم النسبى } & \multirow[b]{2}{*}{ الاسئلةً } & \multicolumn{4}{|c|}{ مستويات عمق المعرفة } & \multirow[b]{2}{*}{ الموضوع } & \multirow[t]{2}{*}{ م } \\
\hline & & الممتد & الاستر اتيجى التفير & والمفاهيق & التانكر و الادتاج & & \\
\hline$\left.\%\right|^{\prime r}$ & 9 & 1 & 1 & $r$ & $\varepsilon$ & مفاهيم أساسية فى التقريم & 1 \\
\hline$\% 1 \cdot .7$ & $\Lambda$ & 1 & 1 & $r$ & $r$ & الاختبارات & r \\
\hline$\% 1 \cdot .7$ & $\Lambda$ & 1 & 1 & $r$ & $r$ & أنواع التقويم التربوى & $r$ \\
\hline$\% 9 . r$ & 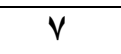 & 1 & 1 & $\mu$ & $r$ & مستويات التقويم & $\varepsilon$ \\
\hline$\% 1 r$ & 9 & $T$ & 1 & $\varepsilon$ & $r$ & أبياناتيب (الملاحظة) & 0 \\
\hline$\% 1 Y$ & 9 & 1 & 1 & $\xi$ & $r$ & الاستبيان & 7 \\
\hline$\% 9 . r$ & $V$ & 1 & 1 & $r$ & $r$ & المقابلة & $V$ \\
\hline$\% 1 \cdot .7$ & $\Lambda$ & 1 & $r$ & $r$ & $r$ & 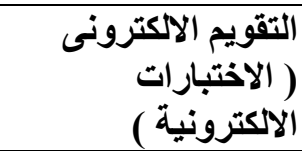 & $\Lambda$ \\
\hline$\% \backslash Y . r$ & 1. & r & 1 & $\varepsilon$ & $r$ & 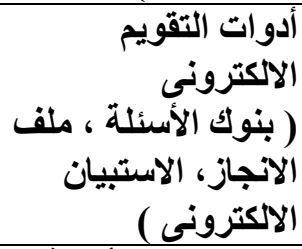 & 9 \\
\hline$\%$ & vo & 1. & 1. & $\mu$. & ro & مجموع الأسئلة & 1. \\
\hline
\end{tabular}

يتضح من الجدول السابق أن اجمالى عدد اسئلة الاختبار هو (V0) سؤالاً ـ ونظراً لان طبيعة الاجابة على فقرات مستوى التفكير الاستراتيجى والتتكير الممتد تحتاج لوقت أطول من هن

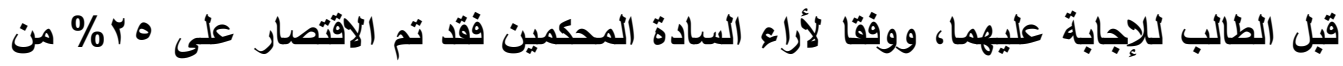
مفردات هذين المستويين، والجدول التالى يوضح عدد الأسئلة موزعة على مستويات عمق لإع

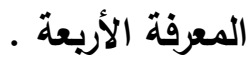

جدول (r) (r)

عدد أسئلة كل مستوى من مستويات عمق المعرفة في الاختبار

\begin{tabular}{|c|c|}
\hline عدد المفردات & المستوى \\
\hline ro & التذكر واعادة الانتاج \\
\hline$r$. & تطبيق المفاهيم و المهارات \\
\hline$\mu$ & التفكير الاستراتيجى \\
\hline$r$ & التفكير الممتد \\
\hline 71 & المجموع الكلى \\
\hline
\end{tabular}


ج- وضع تعميمات الاختبار: تم مراعاة دقة ووضوح التعيمات التي الثتملت على الهذف من الاختبار، والأسئلة المستخدمة فيه، وكيفية الإجابة عليها، وتقدير درجة الاختبار. د - طريقة تصحيح الاختبار: بالنسبة لأسئلة الاختبار من متعدد تم تقدير الإجابة الصحيحة الاجة الصابه لكل مفردة بدرجة واحدة، وصفر لكل إجابة خاطئة أو متروكة؛ ويذلك تكون الارجة

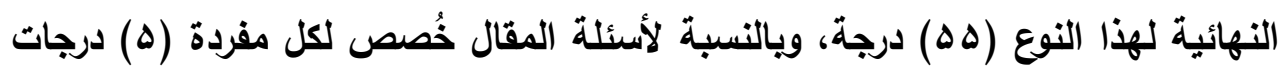
للاجابة الصحيحة وتنقص هذه الارجة حسب صحة الإجابة، وصفر للاجابة الخاطئة أو المتروكة، ويذلك تكون الدرجة النهائية لهذا النوع (ه r) درجة؛ ويالتالي تكون الدرجة

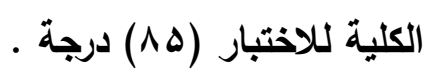

هـ - الخصائص السيكومترية لاختبار مستويات عمق المعرفة : تم التحقق من توافر الشروط السيكومترية ( الصدق - الثبات - الاتساق الاخلي معامل الصعوية والسهولة - معامل التمييز ) للاختبار كالآتي :

أولاً : صدق الاختبسار اعتمدت الباحثتان في هذا البحث على صدق المحكمين ، والصدق التمييزي، وفيما يلي توضيح لذلك: أ. صلدق المحكمين (الصدق الظاهري) ؛ تم عرض الاختبار في صورته الأولية على مجموعة من المتخصصين في مجالى المناهج وطرق تدريس وعلم النفس التريوي ؛ وذلك لإبداء الرأي حول مدى ارتباط المفردات بالهدف من الاختبار وذلك وفقا لبديلين (مرتبطة / غير ولير مرتبطة) ، مدى ملائمة المفردات لكل مستوى من مستويات الاختبار وذلك وفقا لبديلين (ملائمة / غير ملائمة) ، ومدى مناسبة المفردات لمستوى الطلاب وفقا لبديلين

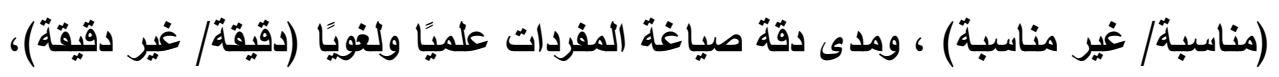
واقتراح التعديل بما يرونه مناسبا سواء بالحذف أو بالإضافة ، ويناءا على أرائهم تم

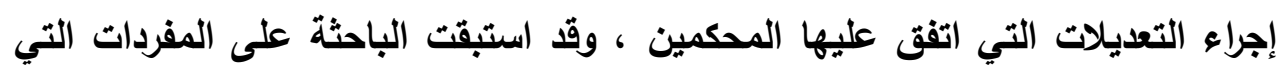

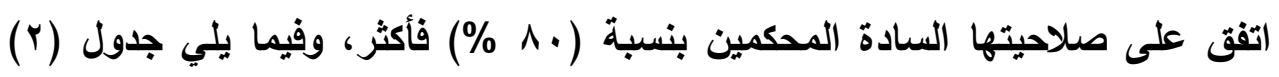
يوضح نسب اتفاق المحكمين على الاختبار ومستوياته وما يتضمنه من مفردات : 


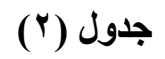

نسب الاتفاق بين المحكمين على اختبار مستويات عمق المعرفة للطالب المعلم بكلية الاقتصاد المنزلي لئي عمي

\begin{tabular}{|c|c|c|}
\hline نسب الاتفاق & المستويات & م \\
\hline$\% 9 \leq .11$ & التذكر وإعادة الإنتاج & 1 \\
\hline$\% 9 r .4$ & تطبيق المفاهيم والمهارات & r \\
\hline$\% 94.9 \leq$ & التفكير الاستراتيجي & $r$ \\
\hline$\% 9 \cdot .91$ & التفكير الممتد & $\varepsilon$ \\
\hline$\% q r . r$ & أثق على الاختبار ككل & \\
\hline
\end{tabular}

ويناء على الملاحظات التي أبداها المحكمين فقد تم الإبقاء على جميع المفردات الواردة بالاختبار ، والتي اجمع عليها الخبراء بأنها مناسبة لقياس مستويات عمق المعرفة للطالب المعلم بكلية الاقتصاد المنزلي ، وقد بلغت نسبة الاتفاق على الاختبار ككل (ץ +. ب؟9\%) وهي نسبة مرتفعة تدل على صلاحية الاختبار وذلك بعد إجراء التعديلات التي أثار إليها المحكمين والتي تضمنت تعديل في صياغة بعض مفردات الاختبار ، ويذلك فقد أصبح الاختبار بعد إجراء تعديلات السادة المحكمين مكون من ( الج) مفردة. ب. الصلق التمبيزي: تم التحقق من الصدق التمييزي للاختبار من خلال حساب الفرق بين المجموعتين (مجموعة الإرياعي الأعلى ، ومجموعة الإرباعي الادني) في الاختبار، وأظهرت النتائج وجود فرق ذو دلالة إحصائية بين المجموعتين كما يبينها الجدول التالي (r):

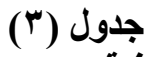

دلالة الفروق بين رتب المجموعات الطرفية (الارباعي الأعلى، والارباعي الأدنى) في اختبار

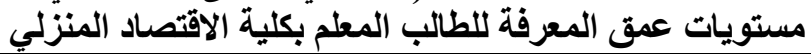

\begin{tabular}{|c|c|c|c|c|c|c|c|}
\hline \multirow{2}{*}{ الدلالة } & \multirow{2}{*}{ قيمة } & \multirow{2}{*}{$\begin{array}{l}\text { قيمة } \\
(\mathbf{W})\end{array}$} & \multirow{2}{*}{$\begin{array}{l}\text { قيمة } \\
\text { (U) }\end{array}$} & \multicolumn{2}{|c|}{ 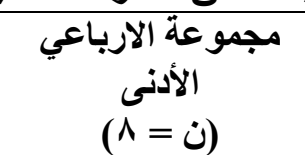 } & \multicolumn{2}{|c|}{ مجموعة الارباعي } \\
\hline & & & & الزتبوع & متوسط الرتب & مجموع & متوسط الرتب \\
\hline مستوى دالة عند & $r_{\text {. }}$ & $r q . .$. & $\because \cdots$ & r.... & $\varepsilon .0$. & $1 \ldots$. & Ir.o. \\
\hline
\end{tabular}




\section{يتضح من الجدول السابق (r):}

أنه يوجد فرق ذو دلالة إحصائية عند مستوي (1 . . ) بين متوسطات رتب درجات

مجموعة الارياعي الأعلى ومتوسطات رتب درجات مجموعة الارياعي الأدنى في اختبار

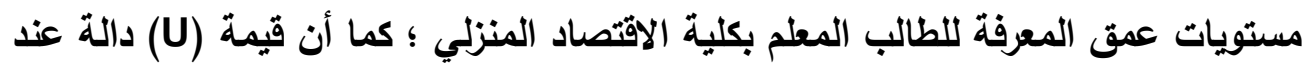
مستوى (1 . ..)؛ مما يدل على الصدق التمبيزي للاختبار، وهذا يعني تمتع الاختبار بلرجة عالية من الصدق.

\section{ثانياً : ثبات الاختبار}

تم حساب ثبات الاختبار بعدة طرق وهي معامل الفا كرونباخ )

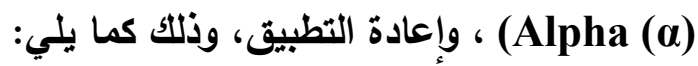

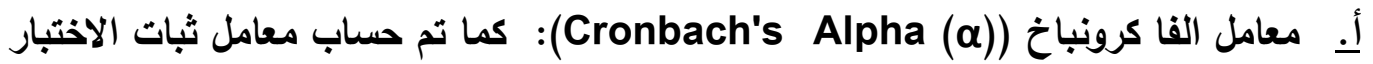

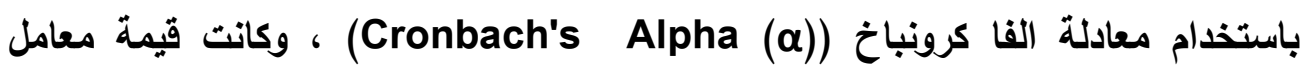

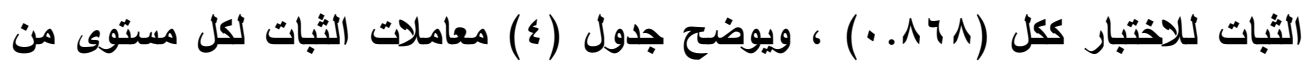

مستويات الاختبار وكذلك الارجة الكلية باستخدام معادلة الفا كرونباخ.

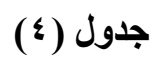

\begin{tabular}{|c|c|c|}
\hline معامل الفا كرونباخ & عدد المفردات & المستويات \\
\hline.$\wedge 10$ & ro & التذكر وإعادة الإنتاج \\
\hline$\cdot$ ๑ง & $r$. & تطبيق المفاهيم والمهارات \\
\hline .9 .0 & $r$ & التفكير الاستراتيجي \\
\hline$\cdot .9 \cdots$ & $r$ & التفكير الممتل \\
\hline 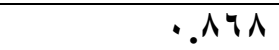 & 71 & الاختبار ككل \\
\hline
\end{tabular}

ب. إعادة التطبيق Test-retest: تم حساب ثبات الاختبار بطريقة التطبيق وإعادة

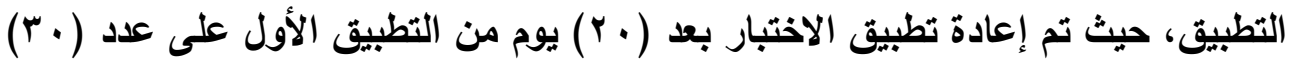
طالب - معلم من طلاب الفرقة الرابعة كلية الاقتصاد المنزلي، وقد وصلت قيمة معامل الثبات

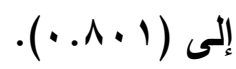

وتدل هذه القيم على أن الاختبار يتمتع بلرجة مناسبة من الثبات لقياس مستويات

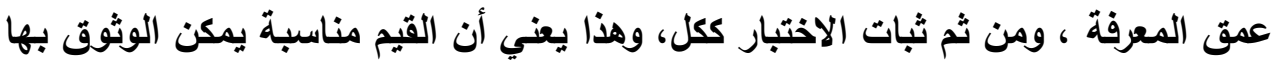

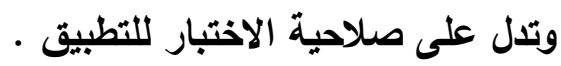


تم التحقق من الاتساق الاخاخلي لاختبار مستويات عمق المعرفة من خلال التطبيق الأي تم للاختبار على العينة الاستطلاعية ، وذلك من خلال ما يلي: ( ) حساب معاملات الارتباط بين مفردات الاختبار والدرجة الكلية للمستويات كل على حده. r) حساب معاملات الارتباط بين الدرجة الكلية لكل مستوى والارجة الكلية للاختبار ككل. وفيما يلي توضيح لذلك كل على حدة :

1. حساب معاملات الارتباط بين مفردات الاختبار والارجة الكلية للمستويات كل على حده: جدول (0)

معاملات الارتباط بين مفردات اختبار مستويات عمق المعرفة ودرجات المستويات كل مستوى على حده

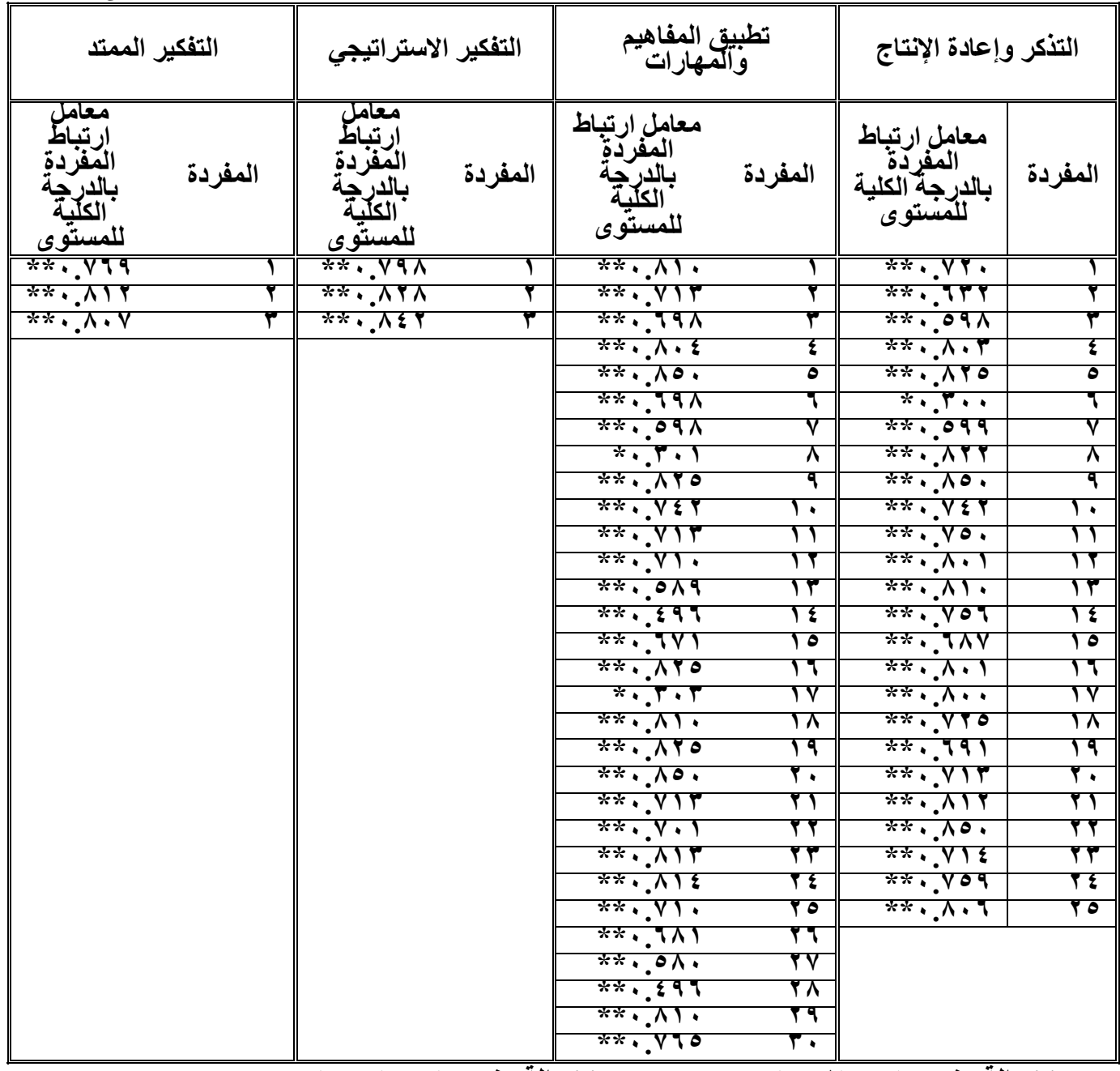

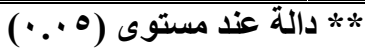

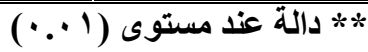


يتضح من الجدول السابق أن معاملات الارتباط بين مفردات الاختبار والدرجة الكلية لكل مستوى على حدة تراوحت ما بين ( · . r. · ) ، و( • • . . ) ، وجميعها دالة إحصائية عند مستوى (1 (...) و (0...).

r. حساب معاملات الارتباط بين الدرجة الكلية لكل مستوى والارجة الكلية للاختبار ككل: جدول (7) معاملات الارتباط بين الارجة الكلية لكل مستوى من مستويات اختبار مستويات عمق المعرفة والدرجة الكلية

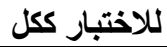

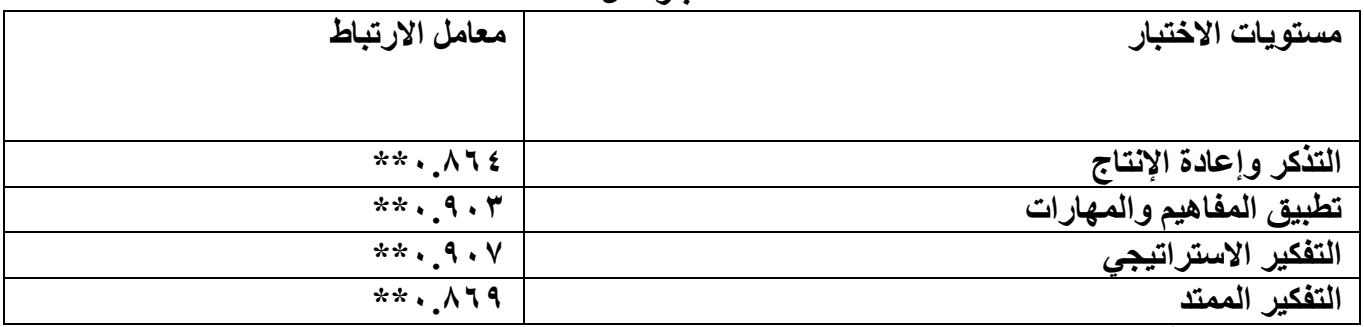

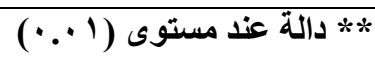

يتضح من الجدول السابق (†) أن معاملات الارتباط بين الارجة الكلية للاختبار والارجة

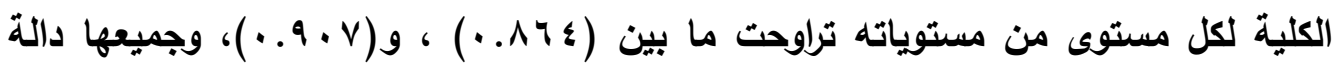
إحصائية عند مستوى (1 (. . ).

ويناءا على ما سبق يتضح من الجدولين السابقين (•) (†) أن معاملات الارتباطات

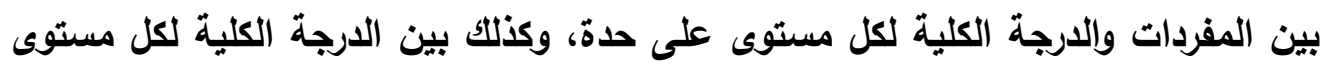
والدرجة الكلية للاختبار ككل جميعها دالة إحصائيا؛ وهو ما يال على ترابط وتماسك المفردات والمستويات والدرجة الكلية؛ مما يشير إلى أن الاختبار يتمتع باتساق داخلي.

رابعا : حساب معامل الصعوبة

تم حساب معامل صعوية لكل مفردة من مفردات الاختبار، وجدول (V) يبين مؤثر

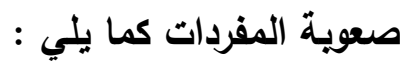




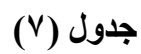

قيم معاملات الصعوبة لمفردات اختبار مستويات عمق المعرفة

\begin{tabular}{|c|c|c|c|c|c|c|c|}
\hline معامل & المفردة & معامل & المفردة & معامل & المفردة & الصعوبة & المفردة \\
\hline$\because 00$ & $\leqslant 9$ & .9. & $r r$ & $\because 0$. & IV & $\because \leqslant 9$ & 1 \\
\hline. .09 & 0 . &.$\Delta 0$ & ז &.$\Delta r$ & 11 & .0 . & $r$ \\
\hline$\cdot .99$ & 01 & $\therefore \leqslant 9$ & ro & $\cdot .00$ & 19 &.$\Delta r$ & $r$ \\
\hline 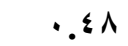 & Or & $\cdot . \leqslant \wedge$ & q & r. & $r$. & . & $\varepsilon$ \\
\hline .0 . & Or &.$\Delta Y$ & $r v$ & .0 . & YI & .00 & 0 \\
\hline ror & $0\}$ & ror & rᄉ & .01 & Yr & .04 & 7 \\
\hline.. $\mathrm{V}$ & $\Delta 0$ & .0 . & rq & 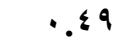 & r & 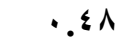 & v \\
\hline .01 & 07 & $\cdot 9$ & $\varepsilon$. & 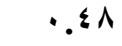 & $r \varepsilon$ & 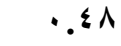 & $\wedge$ \\
\hline .9 & OV &.$\Delta Y$ & $\leqslant 1$ & $\cdot .00$ & Yo & r. & 9 \\
\hline r. & $0 \wedge$ & $\therefore \leqslant 9$ & $\varepsilon r$ & .07 & צ & $.0 \leqslant$ & 1. \\
\hline. $.0 Y$ & $0 q$ & .0 . & $\leqslant r$ & .09 & TV & . & 11 \\
\hline.$\Delta 0$ & 7. & $\therefore 00$ & 纟 &.. $\mathrm{V}$ & Y^ & .09 & Ir \\
\hline \multirow[t]{4}{*}{$\because 0}$. & 11 & & $\leqslant 0$ & .00 & rq &.$\Delta \wedge$ & $1 T$ \\
\hline & & .09 & $\leqslant 7$ & . & r. & 904 & $1 \varepsilon$ \\
\hline & & 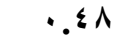 & $\leqslant V$ & .9 & $\mu_{1}$ & .01 & 10 \\
\hline & & $\because \Delta q$ & $\leqslant \wedge$ & $\therefore \leqslant q$ & rr & r.or & 17 \\
\hline
\end{tabular}

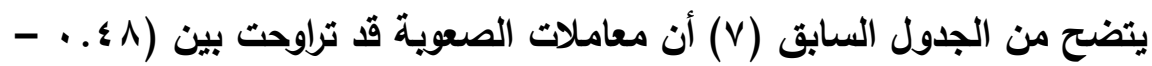

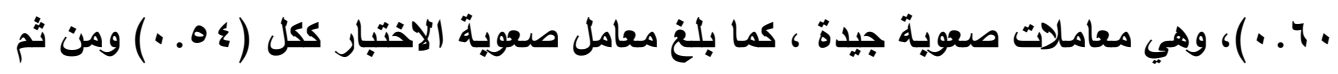
تشير تلكك النتائج إلي صلاحية الاختبار للاستخدام. خامسا : حسيساب معامل التمييز تم حساب معامل تمييز كل مفردة من مفردات اختبار مستويات عمق المعرفة ، والجدول

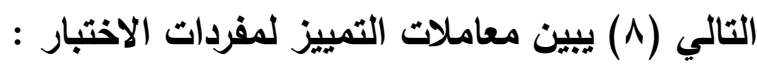




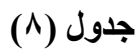

قيم معاملات التمييز لمفردات اختبار مستويات عمق المعرفة

\begin{tabular}{|c|c|c|c|c|c|c|c|}
\hline معامل التمييز & المفردة & معامل التمييز & المفردة & معامل التمييز & المفردة & معامل التمييز & المفرد: \\
\hline. .7. & $\varepsilon 9$ & $\because V V$ & r & $\because .00$ & IV & .7. & 1 \\
\hline .01 & o. &.$\Delta r$ & T &.$V T$ & 11 & .70 & $r$ \\
\hline . & 01 & $\because \wedge 0$ & o &.$\wedge$. & 19 & .00 & $r$ \\
\hline.$V r$ & or & r & q r &.$\wedge 1$ & $r$. &.$\wedge$. & $\varepsilon$ \\
\hline$\because V V$ & or &.$V \varepsilon$ & $r v$ &.$\wedge 0$ & r &.$\wedge r$ & 0 \\
\hline.$\wedge 1$ & $0 \leqslant$ & $\because V V$ & $r \Lambda$ &.$\wedge 0$ & rr &.$v$. & 7 \\
\hline.$V r$ & 00 &.$\vee \wedge$ & rq &.$V$. & rr & .70 & V \\
\hline .77 & 07 &.$\wedge$. & $\varepsilon$. & .00 & $r \varepsilon$ & 7. & $\Lambda$ \\
\hline .09 & ov &.$\wedge 0$ & $\leqslant 1$ & .70 & ro & $\because v 0$ & 9 \\
\hline .00 & $0 \wedge$ &.$\wedge 0$ & $\varepsilon r$ & .71 & q &.$\wedge$. & 1. \\
\hline$\because V \leq$ & 09 & .00 & $\leqslant r$ &.$v^{\prime}$ & $r V$ &.$\wedge r$ & 11 \\
\hline$\cdot \wedge$. & 7. & $.0 \wedge$ & $\varepsilon \varepsilon$ & .00 & $r \Lambda$ & .77 & Ir \\
\hline \multirow[t]{4}{*}{. $.7 v$} & 91 &. $.0 \mathrm{~V}$ & $\leq 0$ & .7 & rq &.$\wedge$. & ir \\
\hline & &.$V T$ & $\leqslant 7$ & $\because V Y$ & $r$. &.$\wedge r$ & $1 \leq$ \\
\hline & &.$\wedge 1$ & $\leqslant V$ & $\because v$. & r &.$\wedge$ & 10 \\
\hline & & $\because \vee 9$ & $\leqslant \Lambda$ &.$V Y$ & rr &.$\wedge \theta$ & 17 \\
\hline
\end{tabular}

من خلال الجدول السابق (^) يتضح أن قيم تمييز مفردات الاختبار تراوحت بين

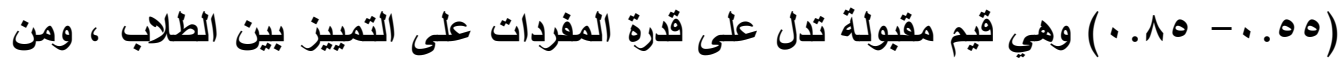
ثم تم الخروج بالاختبار في صورته النهائية بعد التعديلات ( ملحق r r) ، هذا وقد بلغ معامل تمييز الاختبار ككل (VY. . .) ، ومن ثم تشير تلك النتائج إلي صلاحية الاختبار للاستخدام.

\section{الصورة النهائية للاختبار مستويـات عمق المعرفة :}

بعد التأكد من صدق وثبات الاختبار تم اعداده الاختبار في صورة النهائية ليتكون من

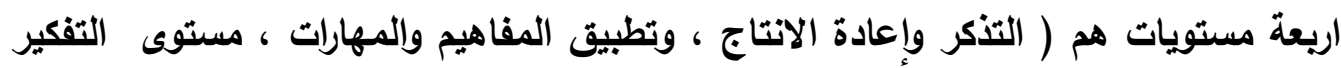

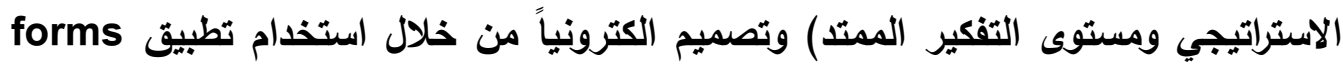
Google https://forms.gle/A4spy6sduSkhNqo2A Class Room ، كما تم ارسال الرابط للطلاب علي Wats App. والجدول التالي يوضح المستويات وعدد المفردات في كل مستوي. 
جدول (9) جوعة (9)

\begin{tabular}{|c|c|}
\hline عدد المفردات & المستوى \\
\hline ro & التذكر و اعادة الانتاج \\
\hline$r$. & تطبيق المفاهيم و المهارات \\
\hline$r$ & التفكير الاستراتيجي \\
\hline r & التفكير الممتد \\
\hline 7. & المجموع الكلى \\
\hline
\end{tabular}

r - إعداد بطاقة ملاحظة جدارات التقويه : قد مرت إعداد بطاقة الملاحظة بالخطوات التالية: أ- تحديد الهدف من بطاقة الملاحظة : تقدير مستوى أداء الطلاب- معلمي الاقتصاد المنزلي لجدارات التقويم ( الجانب المهاري ) أثناء قيامهم بالتدريس الفعلى فى التربية الميدانية قبل ويعد توظيف مراسى التعلم الاكترونى فى تدريس مقرر التقييم التريوى .

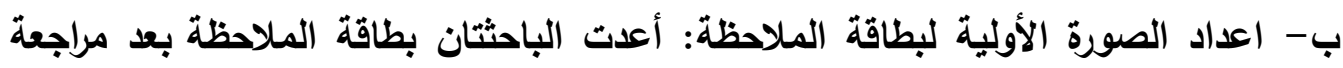
الدراسات و البحوث العربية والأجنبية والأدبيات التى اهتمت بتنمية جدارات التقويم، وذلك الته

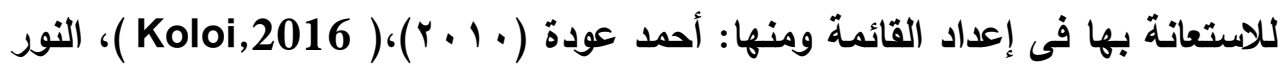

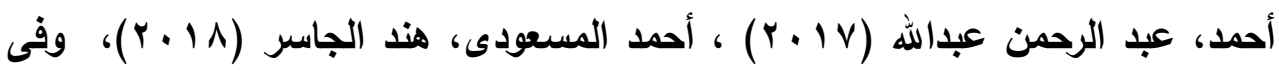
ضوء ذلك تم اعداد قائمة أولية لبطاقة ملاحظة جدارات التقويم تضمنت ( • ؟) جدارة فرعية ، ووضع أمام كل جدارة خمس فئات لتقدير مستوى الأداء موزعة علي ثلاث جدارات رئيسة ( التخطيط ويناء أدوات التقويم- تطبيق وتنفيذ عملية التقويم- تفسير وتحليل نتائج التقويم ) وتم تقدير أداء الطلاب المعلمين علي كل جدارة وفقاً للتدرج الخماسي ( مرتفعة جداً، مرتفع، متوسط، منخفضة، منخفضة جداً ) خصصت لهـ لهذه

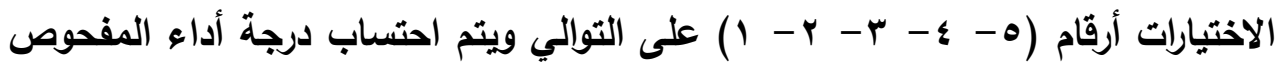

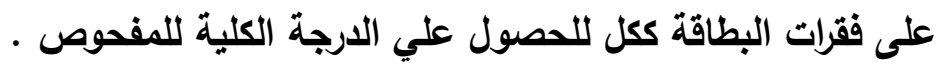
ج - إعداد تعليمات البطاقة: تضمنت تعليمات بطاقة ملاحظة جدارات التقويم بيانات خاصة بالطالب - المعلم ، وكيفية استخدامها من قبل الملاحظ، وكيفية تقدير الدرجات. 
الخصائص السيكومترية لبطاقة ملاحظة جدارات التقويم للطالب المعلم بكلية الاقتصاد المنزلي: قامت الباحثة بالتحقق من توافر الثروط السيكومترية ( الصدق - الثبات - الاتساق الداخلي ) لبطاقة الملاحظة كالآتي :

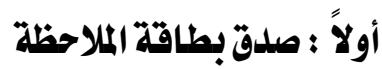

من أجل التأكد من ذلك فقد أمكن الاستدلال بعدة طرق وهم : صدق المحكمين وذلك

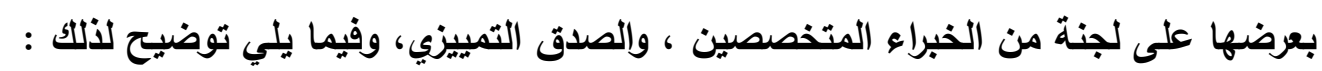

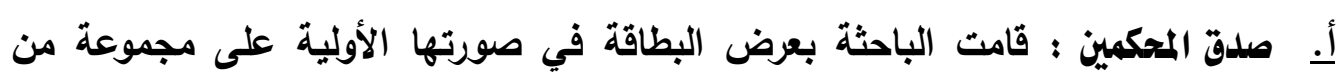
المتخصصين في مجال المناهج وطرق التدريس تخصص اقتصاد منزلي ؛ وذلك لإبداء الرأي حول مدى ملائمة العبارات الدالة على المهارة لبعد تلك المهارة الأي تم تصنفيها تبعا لها، ومدى مناسبتها لتحقيق الأهداف من خلال تنمية جدارات التقويم للطالب المعلم

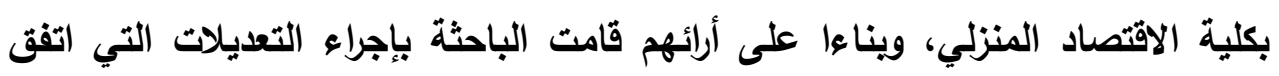
عليها المحكمين ، وقد استبقت الباحثة على الأسئلة التي اتفق على صلاحيتها السادة

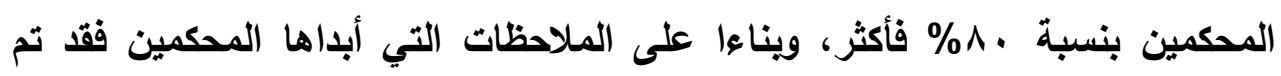
الإبقاء على جميع المهارات الأدائية الواردة ببطاقة الملاحظة ، والتي اجمع علئيها التباء الخبراء

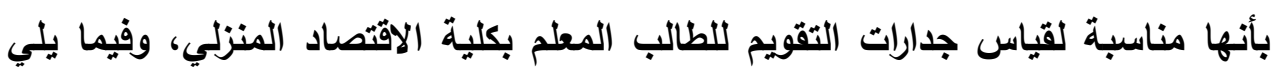
جدول ( • (1) يوضح نسب اتفاق المحكمين على بطاقة الملاحظة وأبعادها وما تتضمنه

$$
\text { من عبارات: }
$$

$$
\text { جدول (·) (1) }
$$

نسب الاتفاق بين المحكمين علي بطاقة ملاحظة جدارات التقويم

\begin{tabular}{|c|c|c|}
\hline نسب الاتفاق & الأبعاد & م \\
\hline$\% 9 \varepsilon .9$ & جدارة التخطيط وبناء أدوات التقويم & 1 \\
\hline$\% q r . .0$ & جدارة تطبيق وتنفيذ عملية التقويم & r \\
\hline$\% 94.01$ & جدارة تحليل وتفسير نتائج التقويم & $r$ \\
\hline$\% 9 r .0 V$ & فاق على البطاقة ككل & \\
\hline
\end{tabular}

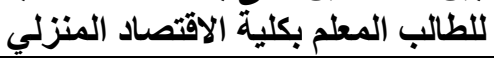

ويناء على الملاحظات التي أبداها المحكمين فقد تم الإبقاء على جميع العبارات الواردة بالبطاقة ، والتي اجمع عليها الخبراء بأنها مناسبة جدارات التقويم للطالب المعلم بكلية

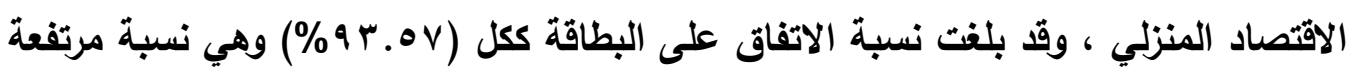


تلال على صلاحية البطاقة وذلك بعد إجراء التعديلات التي أثنار إليها المحكمين والتي تضمنت تعديل في صياغة بعض عبارات البطاقة، ويذلك فقا أصبحت البطاقة بعد إجراء تعديلات السادة المحكمين مكونة من (ع ه) عبارة. ب. الصدق التميزي : تم التحقق من الصدق التمييزي للبطاقة من خلال حساب الفرق بين المجموعتين (مجموعة الإرباعي الأعلى ، ومجموعة الإرباعي الادني) في البطاقة، وأظهرت النتائج وجود فرق ذو دلالة إحصائية بين المجموعتين كما بينها الجدول الإعين التالي الإئي

جدول (1) (الاربات

دلالة الفروق بين رتب المجموعات الطرفية (الارباعي الأعلى، والارباعي الأدنى) في بطاقة ملاحظة جدارات التقويم للطالب المعلم بكلية الاقتصاد المنزلي الاعي الألي

\begin{tabular}{|c|c|c|c|c|c|c|c|}
\hline \multirow[t]{2}{*}{ مستوى الالالة } & \multirow[t]{2}{*}{ قيمة } & \multirow{2}{*}{ قيمة } & \multirow[t]{2}{*}{ قيمة } & \multicolumn{2}{|c|}{ 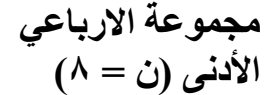 } & \multicolumn{2}{|c|}{ 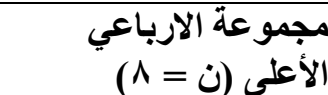 } \\
\hline & & & & مجموع & متوسط & الرجبوع & متوسط \\
\hline مستوى & r. & 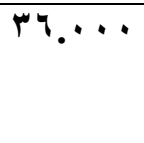 & $\because \cdots$ & rq... & $\varepsilon .0$ & $1 \cdots \cdots$ & $1 Y .0$. \\
\hline
\end{tabular}

يتضـح مـن الجدول السـابق ( • 1) أنـه يوجد فرق ذو دلالـة إحصـائية عند مستوي

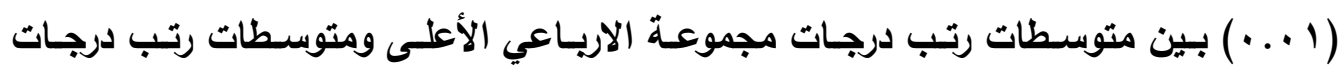

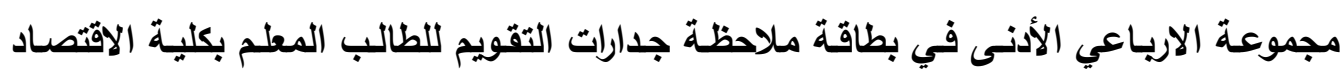

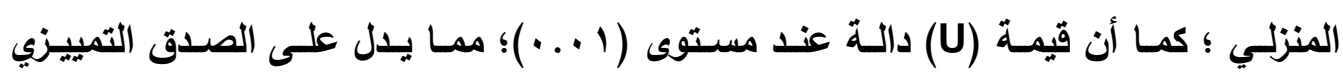

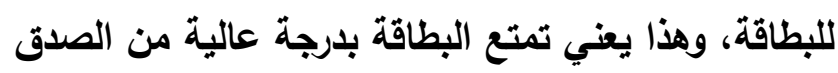

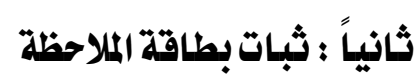

تم تطبيق بطاقة الملاحظة على العينة الاستطلاعية من طلاب كلية الاقتصاد المنزلي

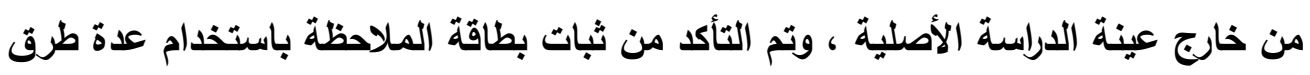

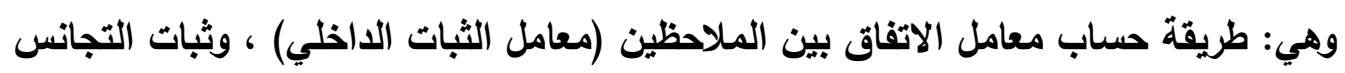
الداخلي بطريقة الفا كرونباخ ، وإعادة التطبيق وذلك كما يلي : 
أ. الثبات الداخلي ( معامل الاتفاق بين الملاحظين ) :

تم حساب ثبات بطاقة الملاحظة بطريقة حساب معامل الاتفاق بين الملاحظين ، حيث تم ملاحظة أداء طلاب كلية الاقتصاد المنزلي على العبارات الواردة بيطاقة الملاحظة أثناء فترة التطبيق الاستطلاعي على أفراد العينة الاستطلاعية من طلاب كلية الاقتصاد المنزلي من قبل

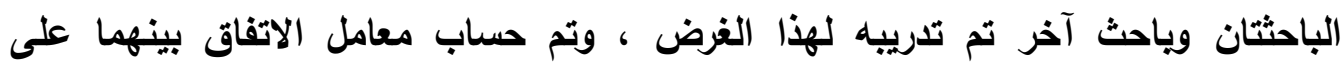

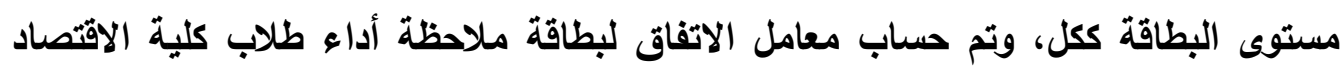

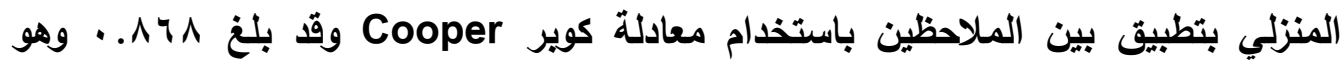
معامل ثبات مرتفع للبطاقة. ب- معامل الفا كرونباخ (Cronbach's Alpha (a) : : كما تم حساب معامل ثبات البطاقة باستخدام معادلة الفا كرونباخ (م) (Cronbach's Alpha) ، وكانت قيمة

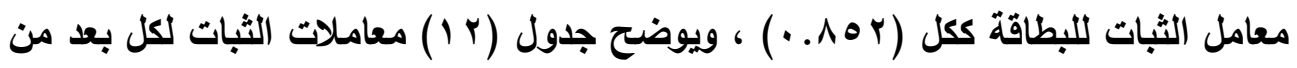
أبعاد البطاقة وكذلك الارجة الكلية باستخدام معادلة الفا كرونباخ.

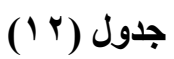

قيم معامل الثبات لكل بعد من أبعاد بطاقة ملاحظة جدارات التقويم

\begin{tabular}{|c|c|c|}
\hline معامل الفا كرونباخ & عدد العبارات & الأبعاد \\
\hline .9 .0 & $r$ & جدارة التخطيط ويناء أدوات التقويم \\
\hline$\cdot \wedge \leqslant q$ & IV & جدارة تطبيق وتنفيذ عملية التقويم \\
\hline.$\wedge 79$ & iv & جدارة تحليل وتفسير نتائج التقويم \\
\hline.$\wedge \otimes r$ & $0\}$ & البطاقة ككل \\
\hline
\end{tabular}

ج. إعادة التطبيق Test-retest: تم حساب ثبات البطاقة بطريقة التطبيق وإعادة التطبيق،

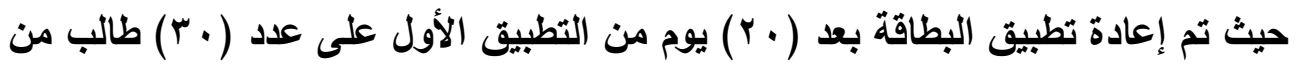
طلاب كلية الاقتصاد المنزبي، وقد وصلت قيمة معامل الثبات إلى (0 9 9 . •). وتدل هذه القيم على أن البطاقة تتمتع بلرجة مناسبة من الثبات لقياس جدارات

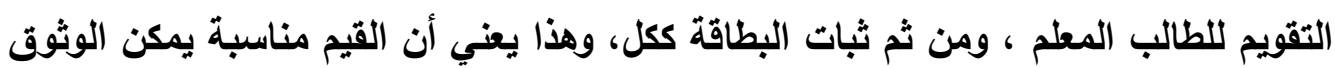

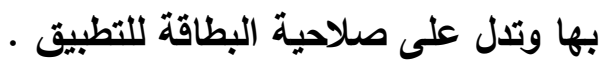


تم التحقق من الاتساق الداخلي لبطاقة ملاحظة جدارات التقويم للطالب المعلم بكلية

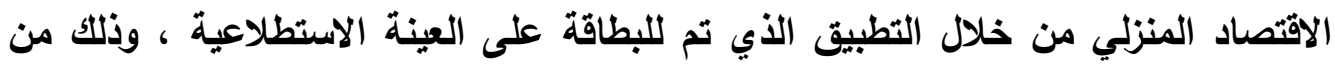

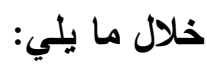
( ) حساب معاملات الارتباط بين عبارات البطاقة والارجة الكلية للأبعاد كل على حده. r حساب معاملات الارتباط بين الدرجة الكلية لكل بعد والارجة الكلية للبطاقة ككل. وفيما يلي توضيح لذلك كل على حدة :

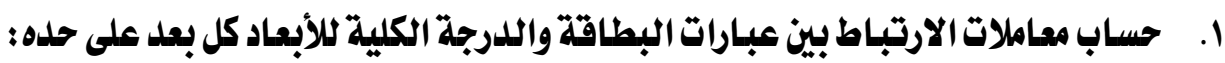

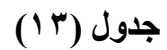
معاملات الارتباط بين عبارات بطاقة ملاحظة جارات التقويم للطالب المعلم بكلية الاقتصاد المنزلي ودرجات

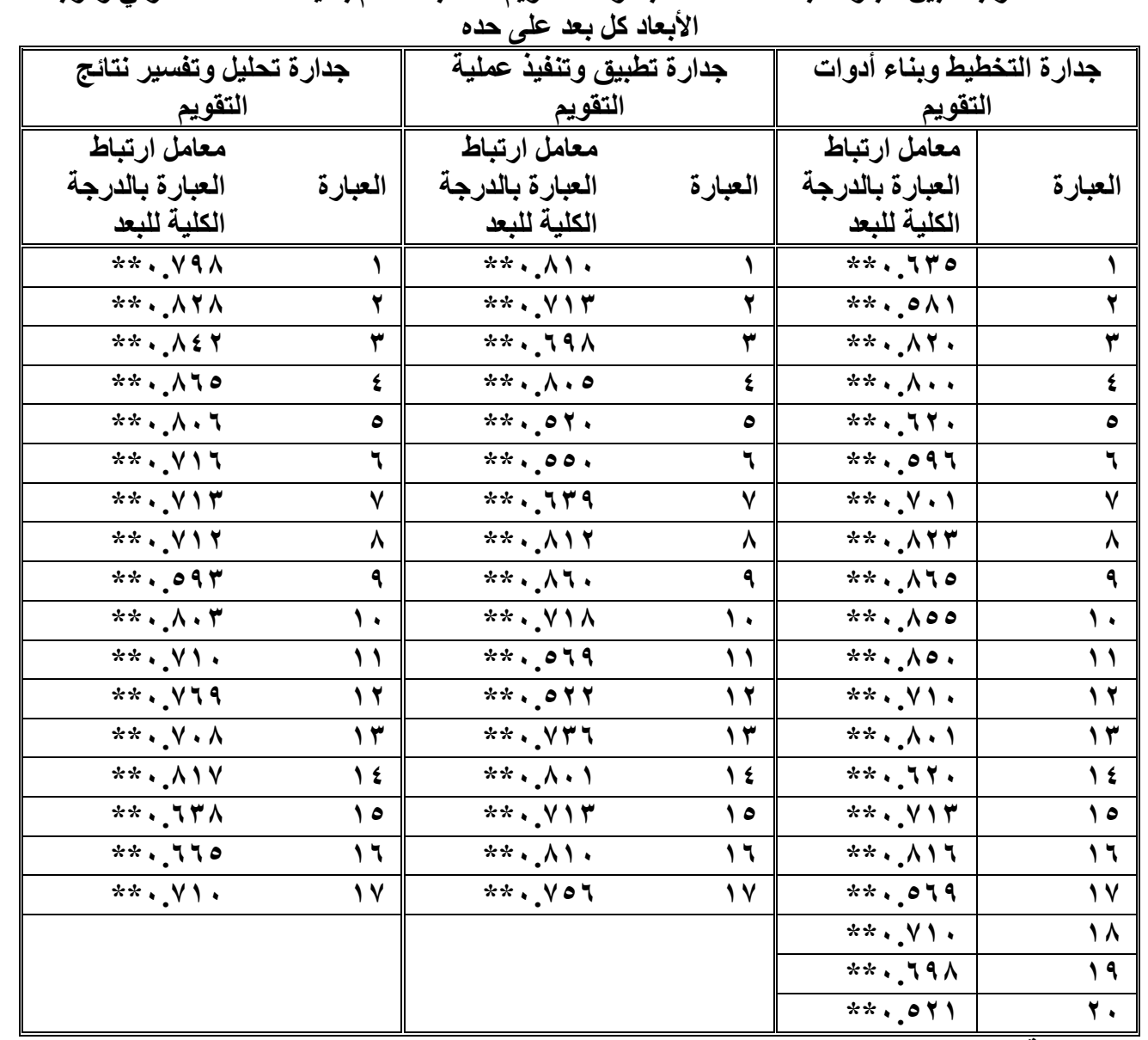

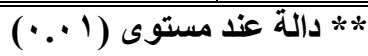


يتضح من الجدول السابق أن معاملات الارتباط بين عبارات البطاقة واللدرجة الكلية لكل

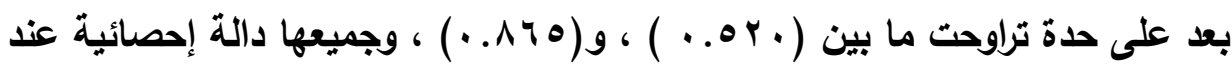

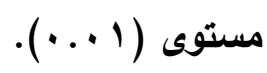
r - حساب معاملات الارتباط بين الدرجة الكلية لكل مستوى والدرجة الكلية للاختبار ككل :

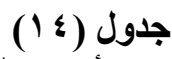
معاملات الارتباط بين الدرجة الكلية لكل بعد من أبعاد بطاقة ملاحظة جدارات التقويم للطالب المعلم

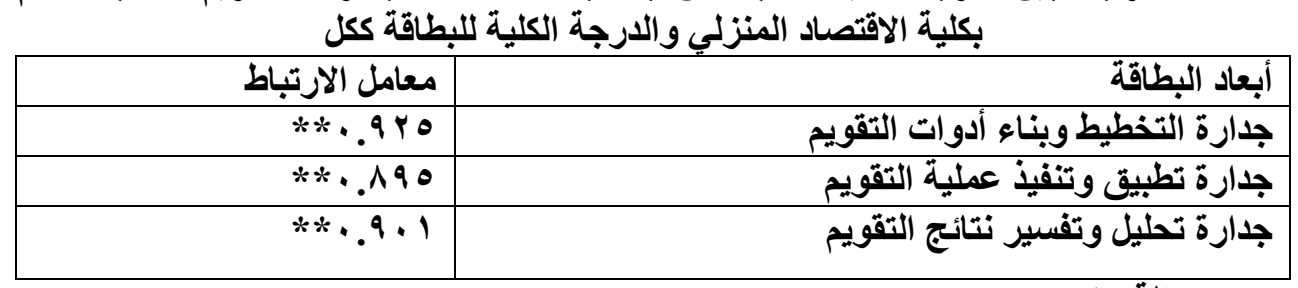

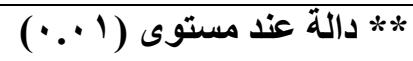
يتضح من الجدول السابق أن معاملات الارتباط بين الارجة الكلية للبطاقة والدرجة الكلية

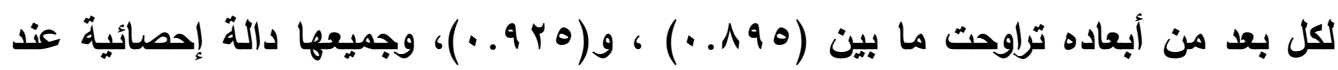

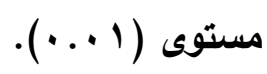

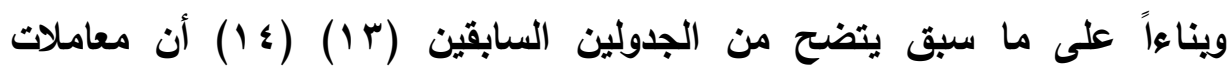

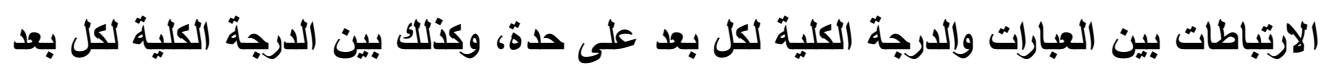

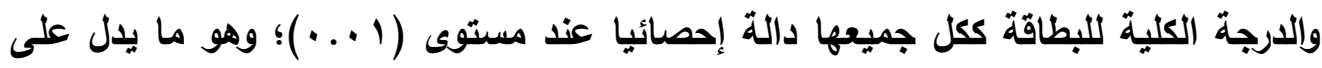
ترابط وتماسك العبارات والأبعاد والدرجة الكلية للبطاقة؛ مما يشير إلى أن البطاقة تتمتع باتساق داخلي.

\section{هـ - الصورة النهائية لبطاقة ملاحظة جدارات التقويه:}

تكونت الصورة النهائية لبطاقة ملاحظة جدارات التقويم علي (ءه) جدارة فرعية مقسمة إلي خمسة أبعاد (التخطيط ويناء أدوات التقويم - تطبيق وتنفيذ عملية التقويم - تفسير وتحليل نتائج التقويم) ويذلك تكون الدرجة العظمي لبطاقة ملاحظة الكفايات ( • rV ) درجة والارجة

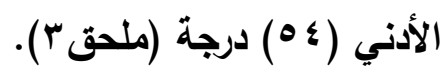


r ب - إعداد مقياس توكيد اللات المهنية : قلد مر إعداد المقياس بـالخطوات التالية - الهذف من المقياس : قياس مدي الطالب المعلم علي تحديد مهارات وقدراته التدريسية ومقدرته علي التعامل مع الطلاب واتخاذ القرات الملائمة في المواقف التعليمية ونظرته

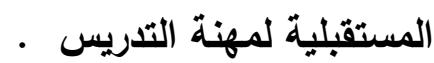
- - بناء المقياس : لبناء المقياس تم الاطلاع علي العديد المصادر والدراسات والبحوث السابقه التي تتاولت توكيد الذات بشكل عام وتوكيد الذات المهنية بشكل خاص ومنها

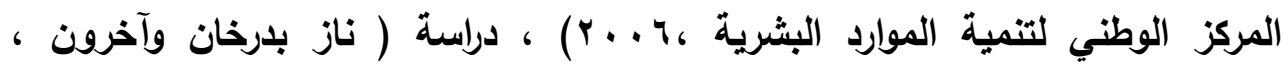

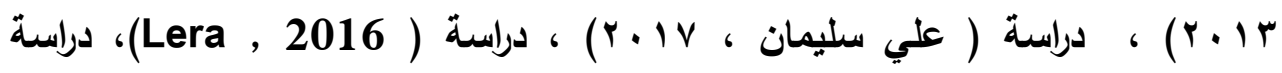

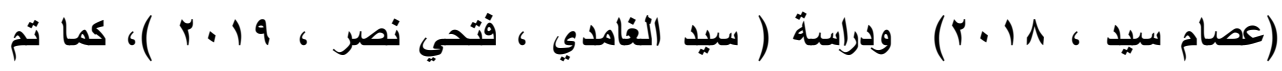
الاطلاع علي دراسات تناولت الذات المهنية ومنها دراسة ( محمود عبد الله ، امجد

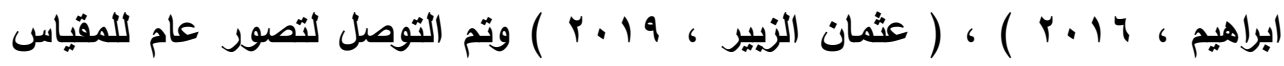
المستخدم في البحث الحالي وابعاده ليتكون من سته ابعاد رئيسية ليتكون من ( r r r ) عبارة موزعه كالتالي :

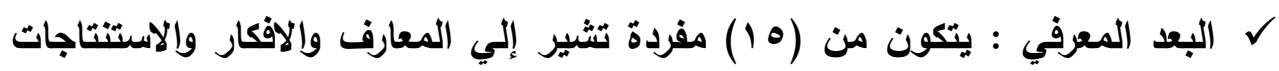

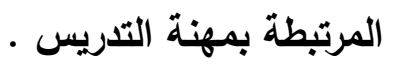

ل البعد النفسي : وتتكون من (1 1 ) عبارة تلل علي مدي كفاءة المعلم علي مواجهة الاخرين وقدرته علي التعبير الواضح والاتزان الانفعالي اثناء اداء الانشطة التدريسية . ل بعد الاداء المهني : ويتكون من ( · ·) عبارة تشير إلي ويشير الي المشاركة بفعالية واستخدام التعبير المناسب تجاه ردود الافعال واستهذام التعزيز الايجابي في المواقف التعليمة وإثاء اداء الانشطة التعليمية .. ل البعد الشخصي والاجتماعي : ويتكون من (Yr) عبارة تشير الي مدي التعاون والتواصل بفاعلية مع الاخرين والتمسك بقيم المجتمع والتعبير عن الرأيفي القضايا

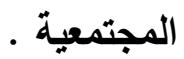
ل البعد القيمي : ويتكون من (• (1) عبارات وتثبر الي التمكك بالموضوعية والامانه

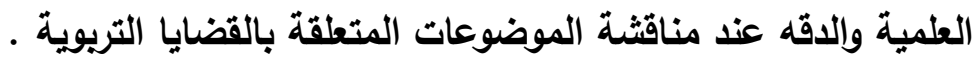




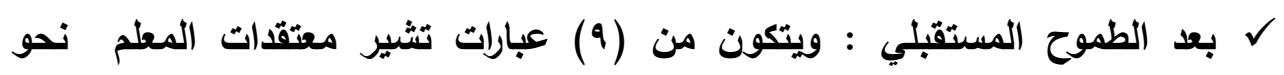

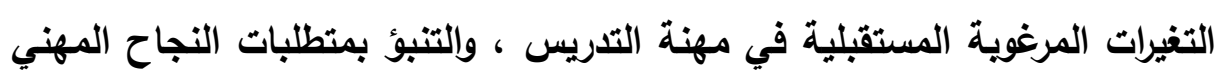

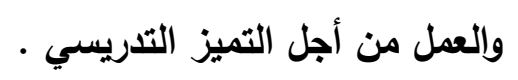

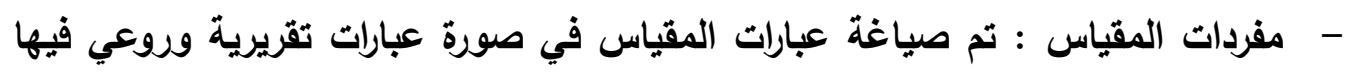

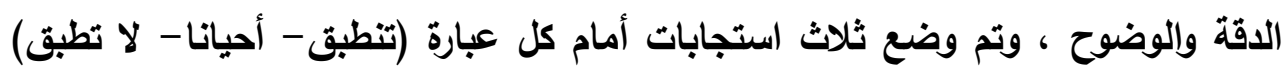

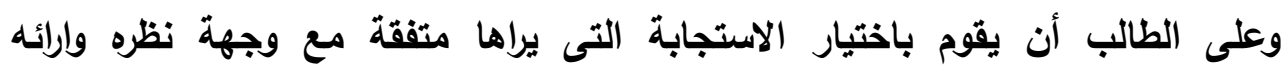

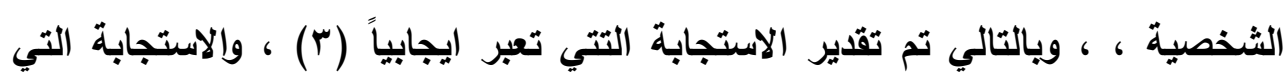

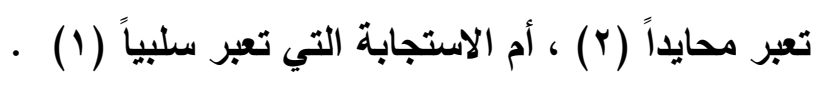

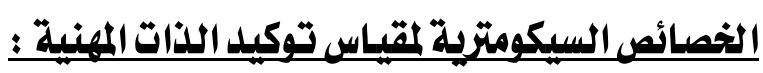
قامت الباحثة بالتحقق من توافر الثروط السيكومترية (الصدق - الثبات - الاتساق الداخلية

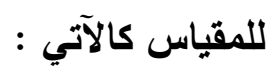
أولا : صدق المياس تم الاعتماد في هذا البحث على صدق المحكمين ، والصدق التمييزي وفيما يلي توضيح لذلك:

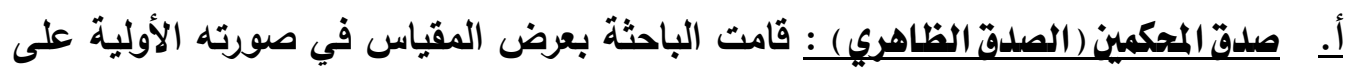

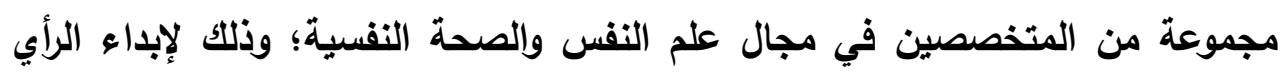

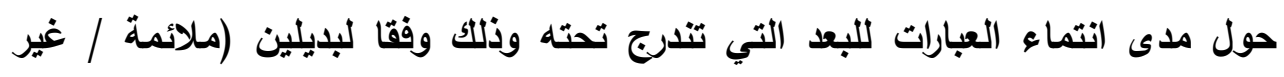

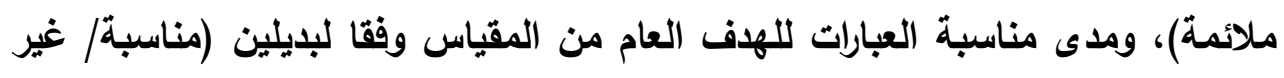

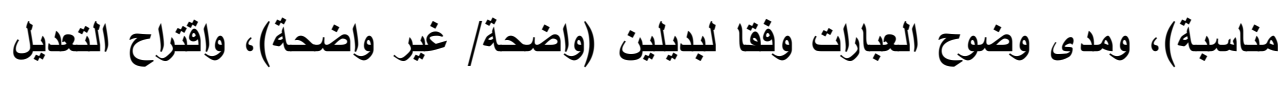

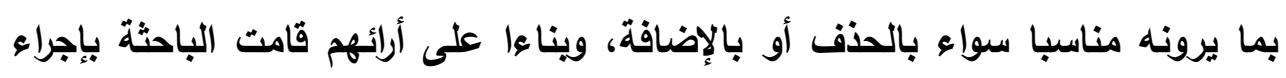

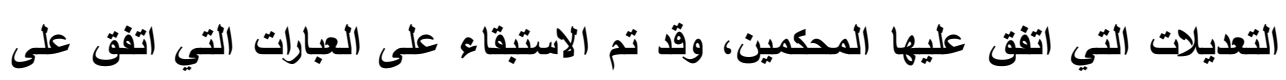

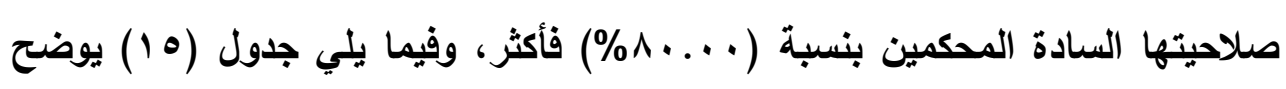
نسب اتفاق المحكمين على المقياس وأبعاده وما تتضمنه من عبارات: 
جدول (10)

نسب الاتفاق بين المحكمين على مقياس توكيد الذات المهنية

\begin{tabular}{|c|c|c|}
\hline نسب الاتفاق & أبعاد المقياس & s \\
\hline \%qr.rr & البعد المعرفى & 1 \\
\hline$\% 9$ r.vo & البعد النفسي & r \\
\hline$\% 94.7 \varepsilon$ & بعد الأداء المهني & $r$ \\
\hline$\% 9 r . \wedge$. & البعد الشخصي والاجتماعي & $\varepsilon$ \\
\hline$\% 94.98$ & البعد القيمي & 。 \\
\hline$\% 9$ \%.q & بعد الطموح المستقبلي & 7 \\
\hline$\% 9 r .0 v$ & على المقياس ككل & \\
\hline
\end{tabular}

ويناء على الملاحظات التي أبداها المحكمين فقد تم الإبقاء على جميع العبارات الواردة بالمقياس، والتي اجمع عليها الخبراء بأنها مناسبة لقياس توكيد الذات المهنية ، وقد تم حساب نسبة الاتفاق بين المحكمين، وقد بلغت نسبة الاتفاق على المقياس ككل (V. وهي نسبة مرتفعة تدل على صلاحية المقياس وذلك بعد إجراء التعديلات التي أشار إليها المحكمين والتي تضمنت تعديل في صياغة بعض عبارات المقياس، ويذلك فقد أصبح المقياس بعد إجراء تعديلات السادة المحكمين مكون من (19) عبارة تم توزيعهم على ستة أبعاد، ويتم الاستجابة عليه وفقا لمقياس ليكرت الخماسي. ب. الصلدقالتمييزي : ويهذف إلى التحقق من قرة المقياس على التمييز بين المستويات المختلفة للمقياس بين الطلاب، وقد تم التحقق من الصدق التمييزي للمقياس من خلال حساب الفرق بين المجموعتين (مجموعة الإرباعي الأعلى، ومجموعة الإرباعي الادني) في المقياس،

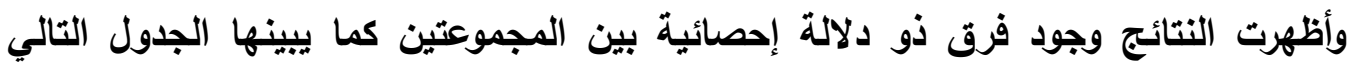

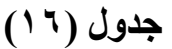

دلالة الفروق بين رتب المجموعات الطرفية (الارباعي الأعلى، والارباعي الأدنى) في مقياس

\section{توكيد الذات المهنية الاعية}

\begin{tabular}{|c|c|c|c|c|c|c|c|}
\hline \multirow[t]{2}{*}{ مستوى } & \multirow[t]{2}{*}{ قيمة } & \multirow{2}{*}{$\begin{array}{l}\text { قيمة } \\
(\mathbf{W})\end{array}$} & \multirow[t]{2}{*}{ قيمة } & \multicolumn{2}{|c|}{ 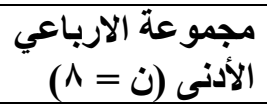 } & \multicolumn{2}{|c|}{ مجموعة الارباعي } \\
\hline & & & & الرثب & متوسط & الرثب & متوسط \\
\hline دالة عند & r.rvr_ & r.... & $\because \cdots$ & rq... & $\varepsilon .0$. & $1 \ldots$ & Ir.o. \\
\hline
\end{tabular}


يتضح من الجدول السابق أنه يوجد فرق ذو دلالة إحصائية عند مستوي (1 (...) بين متوسطات رتب درجات مجموعة الارياعي الأعلى ومتوسطات رتب درجات مجموعة الارياعي الأننى في مقياس توكيد الذات المهنية ؛ كما أن قيمة (U) دالة عند مستوى (1 (U) . •)؛ مما يدل على الصدق التمييزي للمقياس، وهذا يعني تمتع المقياس بدرجة عالية من الصدق. ثانيا : ثبات المقياس

تم حساب ثبات المقياس بعدة طرق وهي معامل الفا كرونباخ ، وإعادة التطبيق كما يلي :

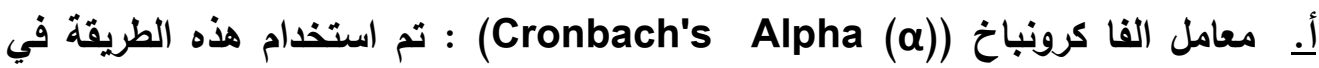
حساب ثبات المقياس وذلك بتطبيقه على عينة قوامها (·r) طالب - معلم بالفرقة الرابعة بكلية الاقتصاد لمنزلي، ويوضح جدول (IV) معاملات الثبات لكل بعد من أبعاد

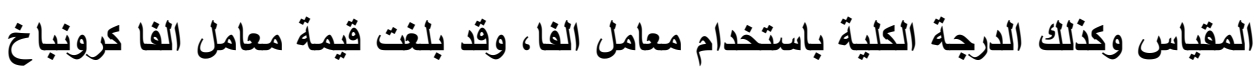

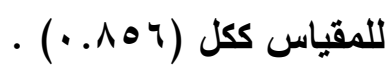

جدول (iv)

قيم معامل الثبات لكل بعد من أبعاد مقياس توكيد الذات المهنية وللمقياس ككل

\begin{tabular}{|c|c|c|}
\hline معامل الفا كرونباخ & عدد العبارات & الأبعاد \\
\hline$\cdot . \wedge \vee \Delta$ & 10 & البعد المعرفي \\
\hline $.91 r$ & 17 & البعد النفسي \\
\hline$\because 9 \leq$ & $r \cdot$ & بعد الأداء المهني \\
\hline.$\wedge r q$ & YY & البعد الثخصي والاجتماعي \\
\hline$\because \wedge \varepsilon$. & 9 & البعد القيمي \\
\hline.$\wedge Y O$ & 9 & بعد الطموح المستقبلى \\
\hline.$\wedge 07$ & 91 & المقياس ككل \\
\hline
\end{tabular}

ب. إعادة التطبيق Test-retest: تم حساب ثبات المقياس بطريقة التطبيق وإعادة التطبيق، حيث تم إعادة تطبيق المقياس بعد (·r) يوم من التطبيق الأول على عدد

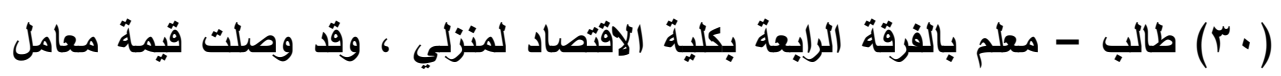

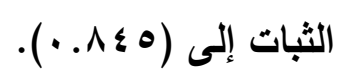

وتدل هذه القيم على أن المقياس يتمتع بدرجة مناسبة من الثبات لقياس توكيد الذات المهنية، ومن ثم ثبات المقياس ككل، وهذا يعني أن القيم مناسبة يمكن الوثوق بها وتدل على لهاب

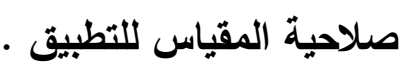


تم التحقق من الاتساق الداخلي لمقياس توكيد الأات المهنية للطالب المعلم بكلية الاقتصاد المنزلي من خلال التطبيق الذي تم للمقياس على العينة الاستطلاعية التي قوامها

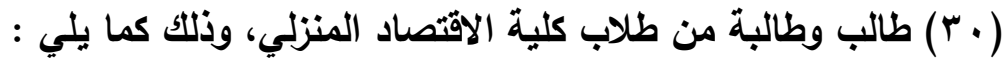
( ) حساب معاملات الارتباط بين عبارات المقياس واللارجة الكلية للأبعاد كل على حده. r) حساب معاملات الارتباط بين الدرجة الكلية لكل بعد والدرجة الكلية للمقياس ككل. وفيما يلي توضيح لذلك كل على حدة :

\section{حساب معاملات الارتباط بِين عبارات المقيساس واللدرحة الكلية للأبعاد كل على حله :}

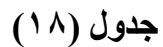

معاملات الارتباط بين عبار ات مقياس توكيد الذات المهنية ودرجات الأبعاد كل بعد على حده

\begin{tabular}{|c|c|c|c|c|c|c|c|c|c|c|c|}
\hline \multicolumn{2}{|c|}{ بعد الطموح المستقبلي } & \multicolumn{2}{|c|}{ البعد القيمي } & \multicolumn{2}{|c|}{ البعد الشخصي } & \multicolumn{2}{|c|}{ بعد الأداء المهني } & \multicolumn{2}{|c|}{ البعد النفسي } & \multicolumn{2}{|c|}{ البعد المعرفي } \\
\hline الارتباط & العبارة & معامل ارتباط العبارة & العبارة & 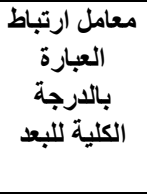 & العبارة & معامل ارتباط & العبارة & الكلبة العبارة للبعاطة & العبارة & الكبالدارة العبارة & العبارة \\
\hline$* *, V I$. & 1 & $* * . \wedge Y 0$ & 1 & $* * \cdot . V \cdot 1$ & 1 & $* * . \wedge 1$. & 1 & $* *, . V \diamond V$ & 1 & $* *, .7$. & 1 \\
\hline$* * .91$. & $r$ & $* * \cdot . \Lambda \cdot r$ & $r$ & $* * . . \wedge$ Y & $r$ & $* * . . \vee 79$ & $r$ & $* * \cdot .9,1$ & $r$ & $* *, . \vee 1$. & $r$ \\
\hline$* * . .7 \mu$ & $r$ & $* * . \vee \vee 79$ & $r$ & $* * \cdot .9 \cdot r$ & $r$ & $* * . . \wedge Y r$ & $r$ & $* * . .91$. & $r$ & $* * \cdot . \wedge r q$ & $r$ \\
\hline$* * . . \vee 79$ & $\varepsilon$ & $* * \cdot v \cdot 1$ & $\varepsilon$ & $* * .91$. & $\varepsilon$ & $* * . \wedge$ ^४ & $\varepsilon$ & $* * \cdot .9, \varepsilon$ & $\varepsilon$ & $* * . .9$, & $\varepsilon$ \\
\hline$* * . \wedge 1$. & 0 & $* * \cdot \Lambda \cdot r$ & 0 & $* *, . V \leq 0$ & 0 & $* * . . \vee 17$ & 0 & $* *$ *.VYr & 0 & $* * . \wedge \mid r$ & 0 \\
\hline **. . & 7 & $* *, .9,0$ & 7 & $* * . .707$ & 7 & $* * . .79$. & 7 & $* * . .701$ & 7 & $* * . . \vee 17$ & 9 \\
\hline$* *, . \wedge \leq 0$ & V & $* * . \wedge 17$ & V & $* *, . \vee \ldots$ & V & $* * . .009$ & V & $* *, .00 \wedge$ & V & $* * . . \vee 99$ & 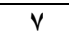 \\
\hline$* *, . \wedge \wedge \varepsilon$ & $\wedge$ & $* *, . \vee \leq 4$ & $\Lambda$ & $* *, . \wedge$ Y & $\Lambda$ & $* * . .07$. & $\wedge$ & $* * . .07$. & $\wedge$ & $* *, . \wedge \mid Y$ & $\Lambda$ \\
\hline$* *, . \wedge 0$. & 9 & $* * . \vee \vee 79$ & 9 & $* * \cdot . \Lambda \cdot r$ & 9 & $* * . V Y$. & 9 & $* *, . \vee \vee q$ & 9 & $* * . . \vee \wedge q$ & 9 \\
\hline & & & & $* * \cdot .7 \cdot 1$ & 1. & $* * . . \vee \wedge 0$ & 1. & $* * . .719$ & 1. & $* * . .7 r q$ & 1. \\
\hline & & & & $* * . . \wedge \ldots$ & 11 & $* * \cdot . \Lambda \cdot r$ & 11 & $* *, . \vee 1 \leq$ & 11 & $* * . .001$ & 11 \\
\hline & & & & $* * . .91$. & $1 \%$ & $* * . .91$. & Ir & $* *, . \vee V Y$ & $1 T$ & $* * \cdot .9 \cdot 1$ & Ir \\
\hline & & & & $* *, . \vee 7 \%$ & $1 T$ & $* * . \wedge 1$. & ir & $* *, . \wedge \cdot 1$ & $1 T$ & $* * . \wedge Y 0$ & ir \\
\hline & & & & $* * \cdot . \wedge \wedge r$ & $1 \leq$ & $* * . . \vee 79$ & $1 \varepsilon$ & $* *, . \wedge \ldots$ & 18 & $* *, . V \leq \square$ & $1 \leq$ \\
\hline & & & & $* *, . \wedge \wedge$. & 10 & $* * \cdot . \wedge \wedge r$ & 10 & $* *, . \vee p q$ & 10 & $* * . \wedge 1 r$ & 10 \\
\hline & & & & $* * \cdot . \wedge$ ४ & 17 & $* * . .7 \mu$ & 17 & $* *, . \wedge$ Y & 17 & & \\
\hline & & & & $* * . \wedge r$. & IV & $* * . \wedge r q$ & IV & & & & \\
\hline & & & & $* * . . V \mid r$ & 11 & $* * . . V 1 \leq$ & 11 & & & & \\
\hline & & & & $* * . .791$ & 19 & $* * \cdot . v \cdot 1$ & 19 & & & & \\
\hline & & & & $* * . .097$ & $r$. & $* * . .701$ & $r \cdot$ & & & & \\
\hline & & & & $* * . \wedge 1$. & YI & & & & & & \\
\hline & & & & $* *, . \wedge \leq V$ & Yr & & & & & & \\
\hline
\end{tabular}

(** دالة عند مستوى (1* 
يتضح من الجدول السابق (IV) أن معاملات الارتباط بين عبارات المقياس والدرجة

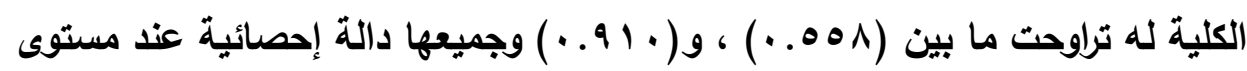
$\cdot(\cdot \cdot 1)$

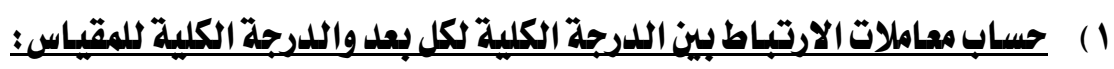

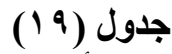

معاملات الارتباط بين الدرجة الكلية لكل بعد من أبعاد مقياس توكيد الذات المهنية والدرجة الكلية

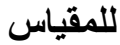

\begin{tabular}{|c|c|}
\hline معامل الارتباط & أبعاد المقياس \\
\hline$* * ., \wedge \wedge \theta$ & لبعد المعرفي \\
\hline$* * .9 .11$ & البعد النفسى \\
\hline$* * ., 100$ & بعد الأداء المهني \\
\hline$* * .910$ & لبعد الشخصى و الاجتماعي \\
\hline$* * . \wedge 70$ & لبعد القيمي \\
\hline$* * . . \wedge \varepsilon$. & بعد الطموح المستقبلى \\
\hline
\end{tabular}

يتضح من الجدول السابق (9 19) أن معاملات الارتباط بين الارجة الكلية للمقياس

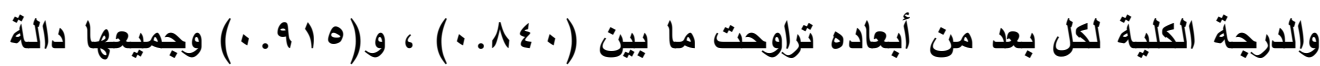
إحصائية عند مستوى (1 ( . •) .

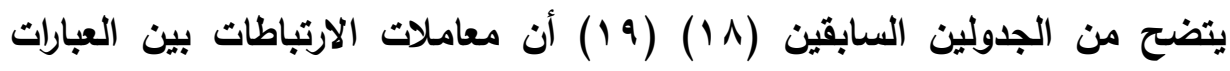
والدرجة الكلية لكل بعد على حده ، وكذلك بين الارجة الكلية لكل بعد والدارجة الكلية للمقياس كلها دالة إحصائيا عند مستوى (0. . .)؛ وهذا يدل على ترابط وتماسك العبارات والأبعاد والمقياس ككل؛ مما يدل على أن المقياس يتمتع باتساق داخليا.

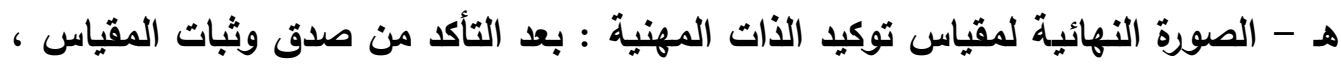

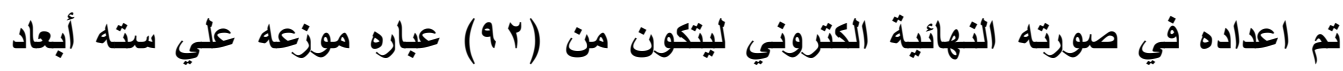

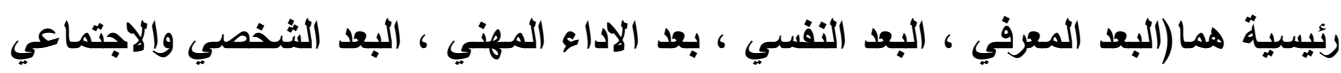

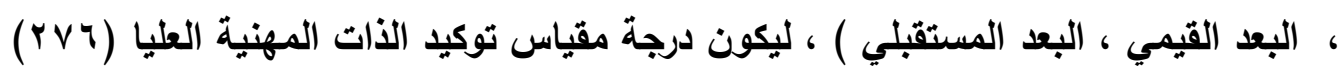

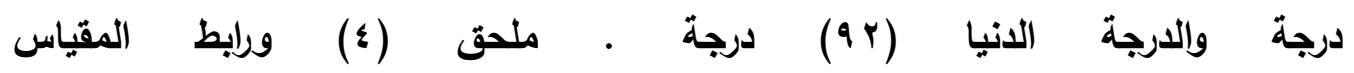
https:/forms.gle/nFAK6Gmm32MfAM7s5

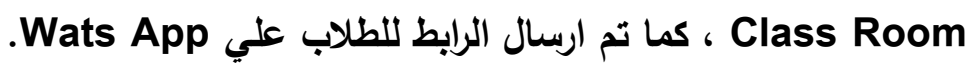


خامسيا : التصميم التحريبي وإحراءات تجرية البحث

1

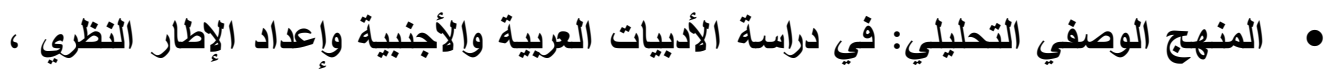
وأدوات البحث وتحليل النتائج وتفسيرها وتقديم التوصيات المقترحة. • المنهج شبه التجريبى ذو المجموعة الواحدة والقياس القبلى والبعدى وذلك للكشف عن ونفئ أثر المتغير المستقل (مراسى التعلم الاكترونى) على المتغيرات التابعة وهى: اكتساب دماب المفاهيم والمحتوى التعليمى بمقرر تقييم تريوى كما يقيسها اختبار مستويات عمث القئ المعرفة المعد لالك - جدارات التقويم - مقياس توكيد الذات المهنية . r

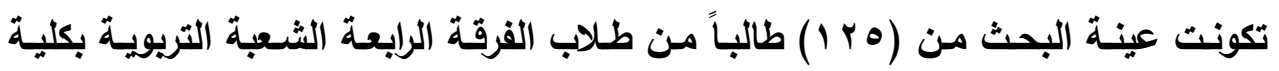
الاقتصاد المنزلي جامعة حلوان، استخدمت كمجموعة وإحدة.

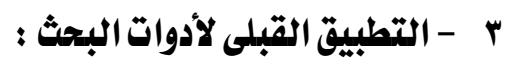

تم تطبيق أدوات البحث قبليًا على المجموعة التجريبية فى الفصل الدراسـى الثانى من

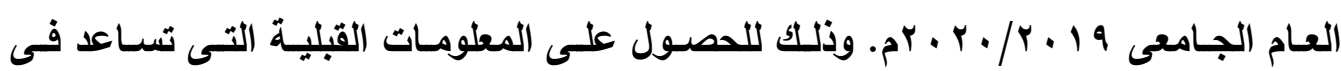
العمليات الإحصائية الخاصة بنتائج البحث. ؟ - تنفيذ تجربة البحث:

تم البدء فى تنفيذ تجريـة البحث في الفصل الدراسي الثاني في شهر فبراير حيث

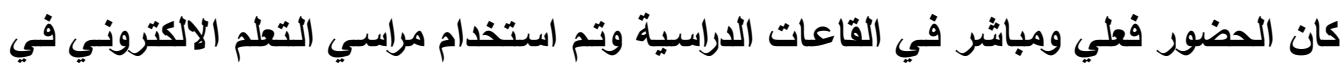
تدريس المقرر، ويعد ظهور ازمة كورونا وتعليق الاراسة المباشرة ساعدت الازمة علي تطبيق التجربـة وكان لها اثر فعال في تحقيق اهداف المقرر ، وقد استغرق تنفيذ التجربـة الفصل

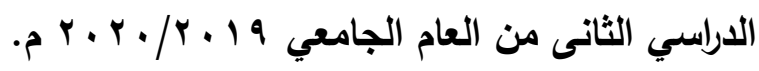

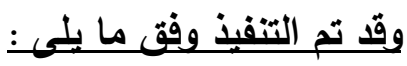

- - قامت الباحثتان بعقد جلسة تمهيدية في اول محاضرة مع الطلاب المعلمين (عينة البحث) ، حيث كانت المحاضرة مباشرة بالقاعات الاراسية وذلك لشرح الهـف من التجرية، وتحفيزهم على المشاركة والتفاعل، وتم تعريف الطلاب بالمواقع المختلفة لمراسي التعلم 


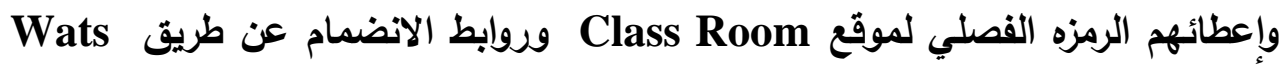
App ، كما تم توضيح المهام المطلوب انجازها. - دعت الباحثتان الطلاب لمشاهدة المحتوى التعليمى لمقرر تقييم تريوى من خلال المحاضرات التي تم رفعها على Class Room، ومناقشتها مع الطلاب أثناء الشرح. و

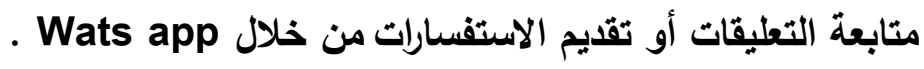
- - المتابعة والتقويم المستمر للطلاب المعلمين أثناء التعليم والتعلم ـ من خلال تقويم المهام التشاركية، ومتابعة مهام التعلم والتعليقات على الصور والفيديوهات التى يرفعها الطلاب وتقديم التفذية الراجعة المناسبة ، و ملحق (•) يوضح بعض المهمات التعليمية التى قام الطلاب المعلمين بأدائها ورفعها سواء من خلال Class Room أو جروب Wats . الخاص بالمقرر أوApp Doogle Drive 0 بعد الانتهاء من التدريس باستخدام مراسي التعلم تم تطبيق أدوات البحث بعديًا. وذلك

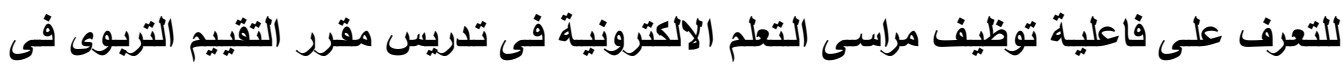
تنمية مستويات عمق المعرفة وجدارات التقويم وتوكيد الذات المهنية لدى الطلاب المعلمين. 7 تـم اسـتخدام الحزمـة الإحصـائية للعلـوم الاجتماعيـة SPSS Ver.22 في إلابهـاء التحليلات الإحصائية ، والأساليب المستخدمة في هذا البحث هي:

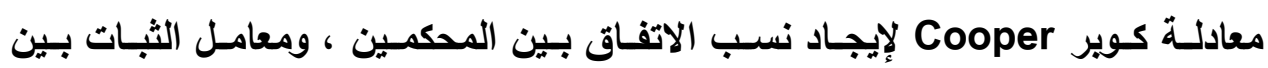
الملاحظين. أسلوب الفا كرونباخ وإعادة التطبيق لحساب ثبات الأدوات. اختبار مان وتيني Mann-Whitney لحساب الصدق التمييزي لأدوات القياس. معامل ارتباط بيرسون Pearson بين درجة كل مفردة أو عبارة والدرجة الكليـة للمحور لادئي الذي تنتمي إليه؛ وذلك لتقدير الاتساق الداخلي للأدوات.

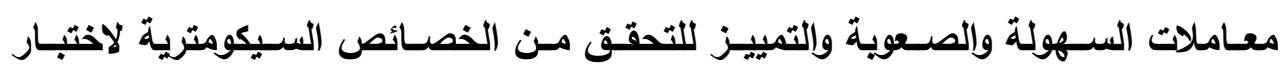
مستويات عمق المعرفة. 
اختبار "ت" للمجموعات المرتبطة test لبحث دلالـة الفروق بـين درجـات التطبيقين

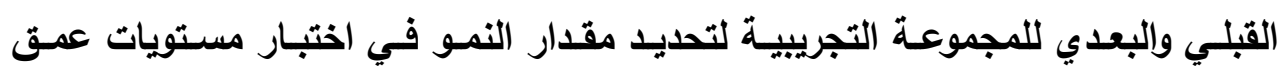

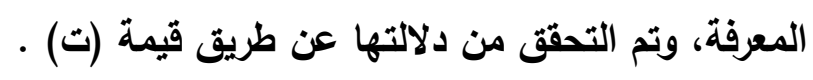

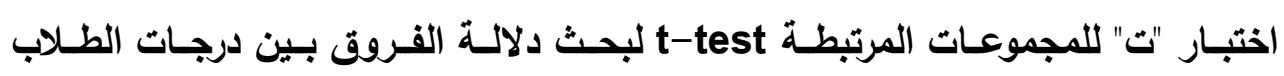
المعلمين فى التطبيقين القبلي والبعدي لتحديد مقدار النمو في بطاقة ملاحظة جدارات

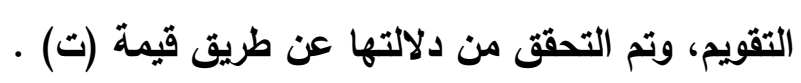

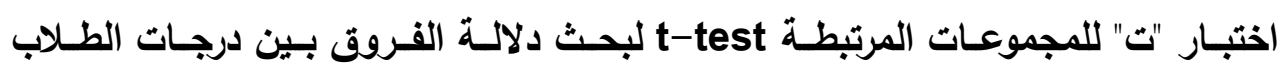

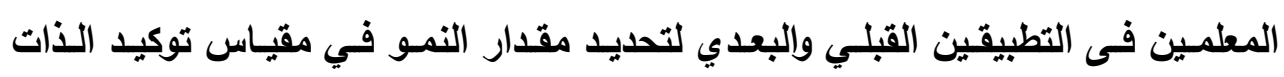

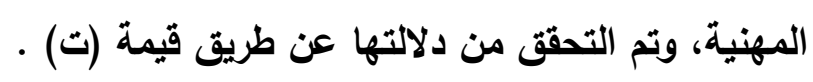

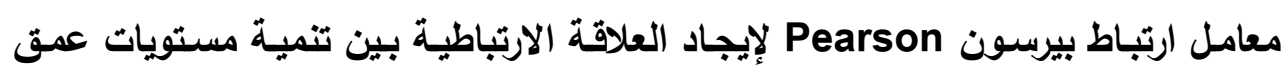
المعرفة وتنمية جدارات التقويم وتوكيد الأات المهنية لدى طلاب المعلمين (عينة البحث).

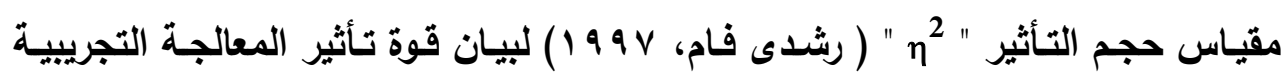

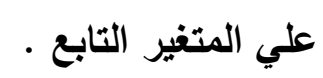

سادساً: عرض نتائج البحث، ومناقشتهها، وتقسيرهـا :

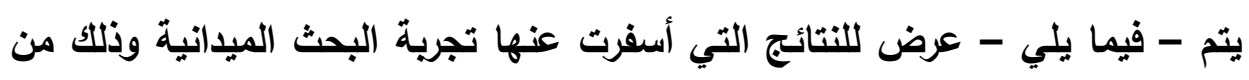

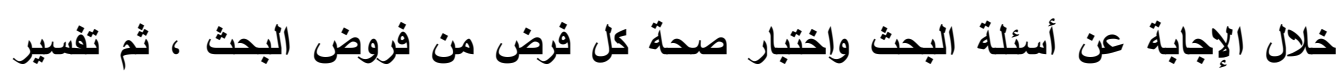

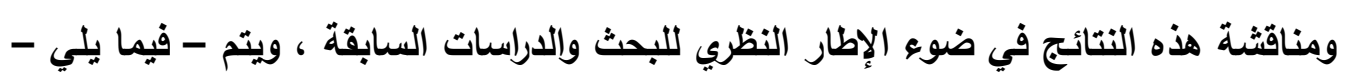

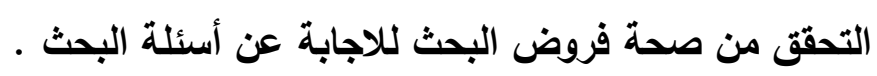

\section{اختبار صحة الفرض الأول:}

ينص الفرض الأول من فروض البحث على أنه : "يوجد فرق دال إحصائياً بين متوسطات

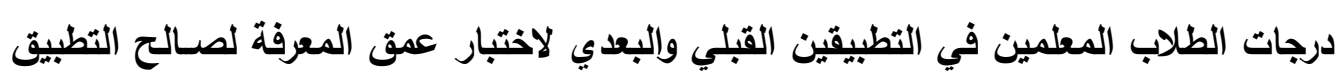

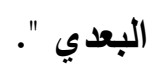


وللتحقى من صحة هذا الفرض تم حساب قيمة (ت) لمتوسطين مرتبطين ومدى دلالتها للفرق بين متوسطي درجات طلاب المجموعة التجريبية في التطبيقين القبلي والبعدي لاختبار

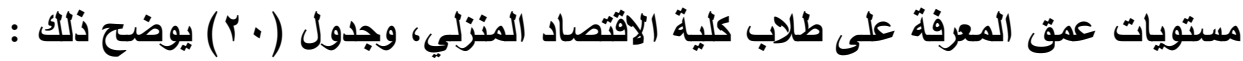

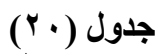

قيمة "ت" ومستوى دلالتها للفرق بين متوسطي درجات الطلاب المعلمين في التطبيقين القبلي والبعدي لاختبار عمق المعرفة (ن = ه ب l )

\begin{tabular}{|c|c|c|c|c|c|c|c|c|c|c|c|}
\hline حجتُ & قيمة & قيمة & الدلالة & المحسوبة & دالدرية & اللفعياري الانحراف & الالحرياري & الفين & الحستبي & التطبيق & المستويات \\
\hline \multirow[b]{2}{*}{ كبيز } & \multirow[b]{2}{*}{17.197} & \multirow[b]{2}{*}{$.99 \leqslant$} & \multirow{2}{*}{ 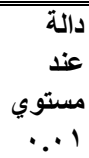 } & \multirow[b]{2}{*}{$1 \leqslant V . \Delta r V$} & \multirow[b]{2}{*}{$M \varepsilon$} & \multirow[b]{2}{*}{$1 . \leqslant v$. } & $1 . r \leqslant 1$ & \multirow[b]{2}{*}{19.8.} & $\{.0 \leqslant$ & القبلي & \multirow{2}{*}{ الإعادة } \\
\hline & & & & & & & $\because \vee \vee 9$ & & Yr.q\& & البعدي & \\
\hline \multirow[b]{2}{*}{ كبيز } & \multirow[b]{2}{*}{$1 \% .110$} & \multirow[b]{2}{*}{$.99 \leq$} & \multirow{2}{*}{ ع عند } & \multirow[b]{2}{*}{$1 \leqslant V . \leqslant 17$} & \multirow[b]{2}{*}{ ITE } & \multirow[b]{2}{*}{$1.04 \varepsilon$} & 1.511 & \multirow[b]{2}{*}{$r \cdot . r r$} & 1.०. & القبلي & \multirow[b]{2}{*}{ تطبيق } \\
\hline & & & & & & & $1 . r V$ & & $r \wedge . V r$ & البعدي & \\
\hline \multirow{2}{*}{ كبير } & \multirow{2}{*}{$9 . . r$} & \multirow{2}{*}{$\cdot .911$} & \multirow{2}{*}{ مستد 1 دالة } & \multirow{2}{*}{$1 \cdots .709$} & \multirow{2}{*}{ Irs } & \multirow{2}{*}{$1 . r 0 \leq$} & $\because \vee \vee q$ & \multirow{2}{*}{19.19} & $1 . r \Lambda$ & القبلي & \multirow{2}{*}{ الاستريز } \\
\hline & & & & & & & $1 .+r \leq$ & & $1 \mathrm{r} .0 \mathrm{~V}$ & البعدي & \\
\hline \multirow[b]{2}{*}{ كبير } & \multirow[b]{2}{*}{ A. } & \multirow[b]{2}{*}{$\cdot .914$} & \multirow{2}{*}{ 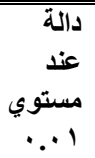 } & \multirow[b]{2}{*}{94.919} & \multirow[b]{2}{*}{$M \varepsilon$} & \multirow[b]{2}{*}{$1 . \leqslant r \Lambda$} & $\because V \leqslant 0$ & \multirow[b]{2}{*}{11.14} & 1.11 & القبلي & \multirow[b]{2}{*}{ المتفكير } \\
\hline & & & & & & & $1 . \leqslant 40$ & & 14.00 & البعدي & \\
\hline \multirow[b]{2}{*}{ كبير } & \multirow[b]{2}{*}{$19.0 \wedge r$} & & دالة & & & & Y.YYA & & 10.71 & القبلي & \\
\hline & & $\because 99 \mathrm{~V}$ & مستوي & $Y 1 \wedge . q \leq 0$ & IY & r.ror & Y.rq৭ & אד. זי & vq. rq & البعدي & الاختبار ككل \\
\hline
\end{tabular}

يتضح من الجدول السابق ما يلي :

- ارتفاع متوسط درجات الطلاب المعلمين فى التطبيق البعدي عن متوسط درجات التطبيق القبلي في مستوى التذكر وإعادة الإنتاج باختبار عمق المعرفة، حيث حصل الطلاب

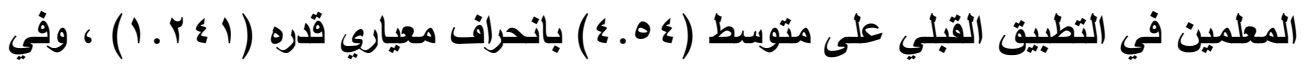

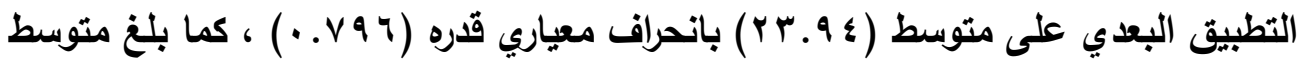
الفرق بين التطبيقين القبلي والبعدي لمستوى التذكر وإعادة الإنتاج باختبار عمق المعرفة ( •.4 1 ) درجة، وقيمة (ت) المحسوية لالالة الفرق بين متوسطي درجات الطلاب 
المعلمين في التطبيقين القبلي والبعدي لمستوى التذكر وإعادة الإنتاج باختبار عمث

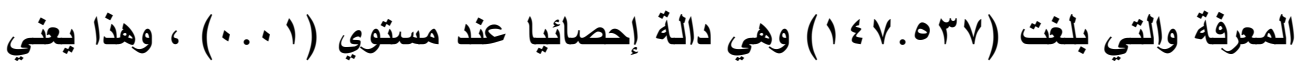
وجود فرق ذو دلالة إحصائية بين متوسطي درجات الطلاب في التطبيقين القبلي والبعدي

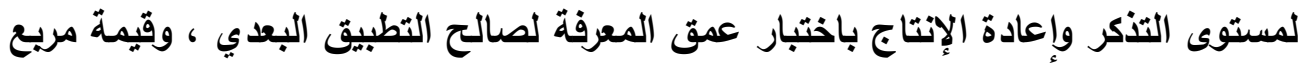

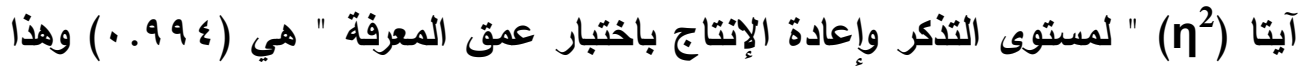
يعني أن نسبة (؟.9 \%\%) من التباين الحادث في مستوى التذكر وإعادة الإنتاج باختبار عمق المعرفة (المتغير التابع) يرجع إلى توظيف مراسي التعلم الاكتروني (المتغير

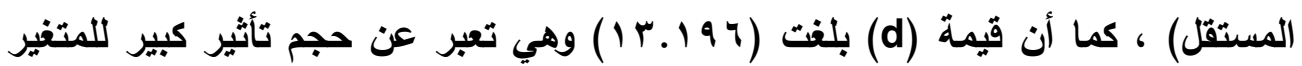

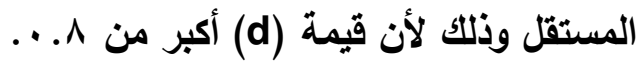

ارتفاع متوسط درجات الطلاب المعلمين فى التطبيق البعدي عن متوسط درجات التطبيق

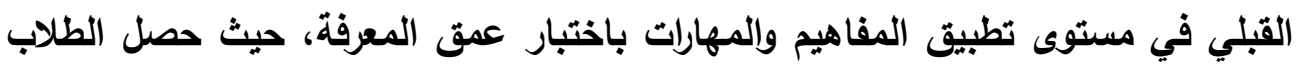

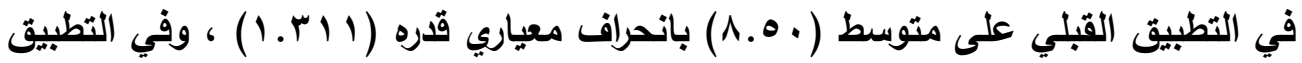

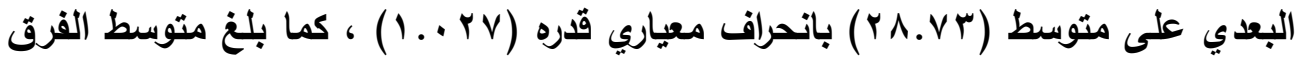
بين التطبيقين القبلي والبعدي لمستوى تطبيق المفاهيم والمهارات باختبار عمق المعرفة

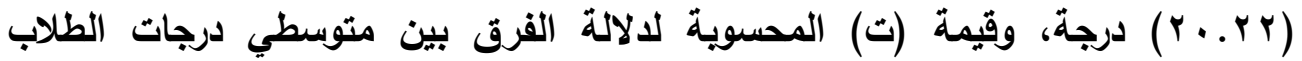
المعلمين في التطبيقين القبلي والبعدي لمستوى تطبيق المفاهيم والمهارات باختبار عمق لهق

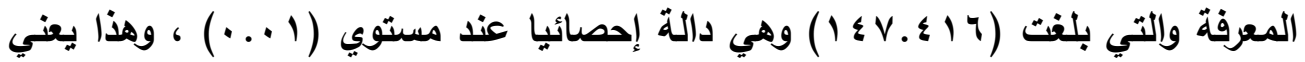
وجود فرق ذو دلالة إحصائية بين متوسطي درجات الطلاب في التطبيقين القبلي والبعدي

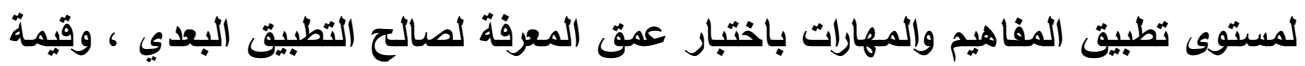

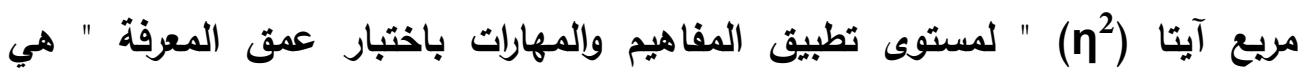

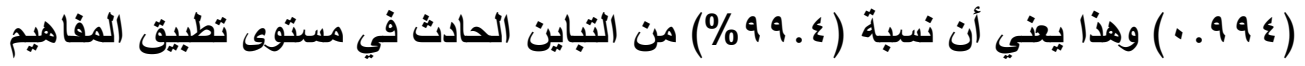
والمهارات باختبار عمث المعرفة (المتغير التابع) يرجع إلى توظيف مراسي التعلم

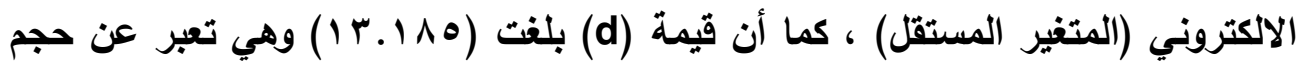
تأثير كبير للمتغير المستقل.

- ارتفاع متوسط درجات الطلاب المعلمين التطبيق البعدي عن متوسط درجات التطبيق القبلي في مستوى التفكير الاستراتيجي باختبار عمق المعرفة، حيث حصل الطلاب في مئ مئ 


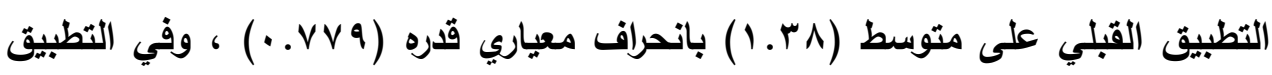

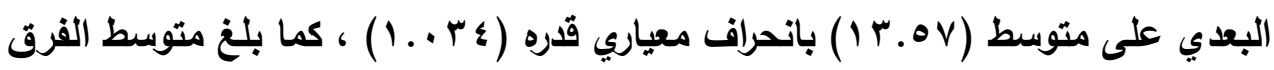
بين التطبيقين القبلي والبعدي لمستوى التفكير الاستراتيجي باختبار عمق المعرفة

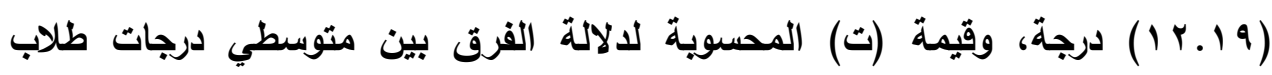
الطلاب المعلمين في التطبيقين القبلي والبعدي لمستوى التفكير الاستراتيجي باختبار

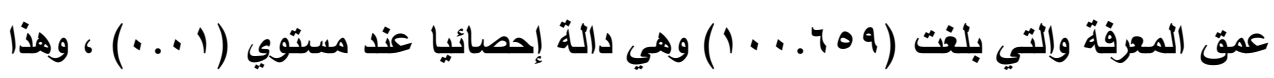
يعني وجود فرق ذو دلالة إحصائية بين متوسطي درجات الطلاب في التطبيقين القبلي

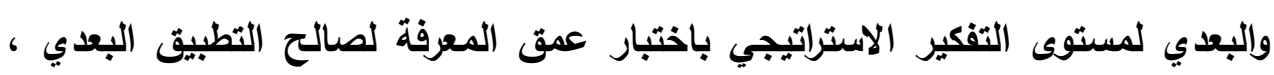

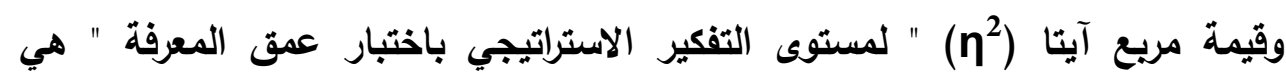

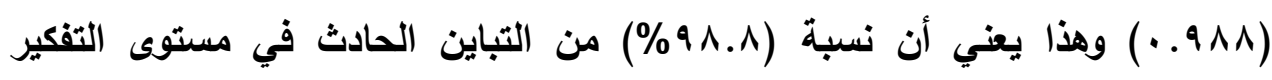
الاستراتيجي باختبار عمث المعرفة (المتغير التابع) يرجع إلى توظيف مراسي التعلم

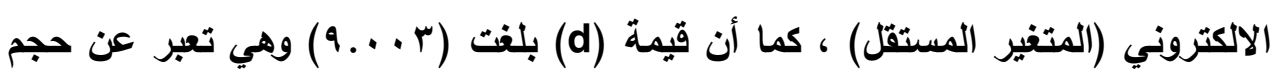
تأثير كبير للمتغير المستقل.

ارتفاع متوسط درجات الطلاب المعلمين فى التطبيق البعدي عن متوسط درجات التطبيق القبلي في مستوى التفكير الممتد باختبار عمق المعرفة، حيث حصل الطلاب في التطبيق

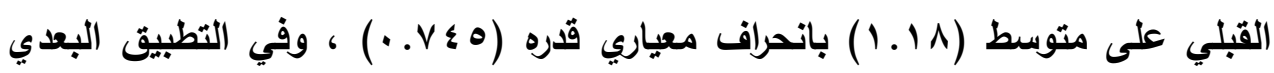

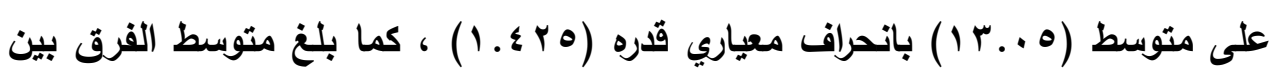

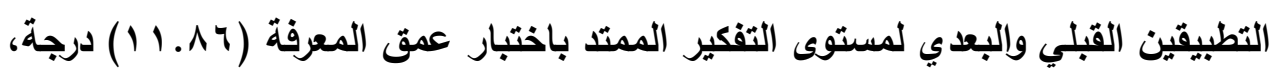
وقيمة (ت) المحسوية لالالة الفرق بين متوسطي درجات الطلاب المعلمين في التطبيقين

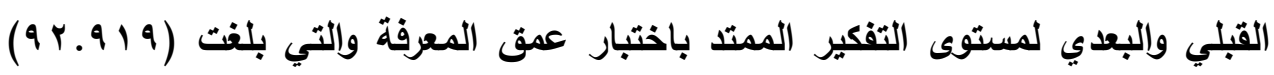
وهي دالة إحصائيا عند مستوي (1 (. .) ، وهذا يعني وجود فرق ذو دلالة إحصائية بين متوسطي درجات الطلاب في التطبيقين القبلي والبعدي لمستوى التفكير الممتد باختبار

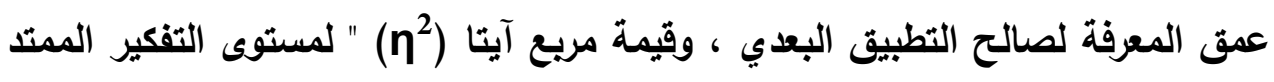

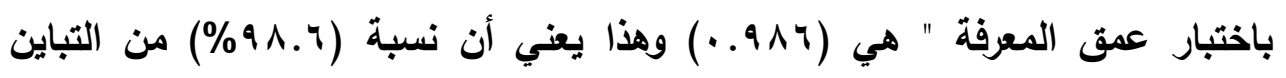
الحادث في مستوى التفكير الممتد باختبار عمق المعرفة (المتغير التابع) يرجع إلى 


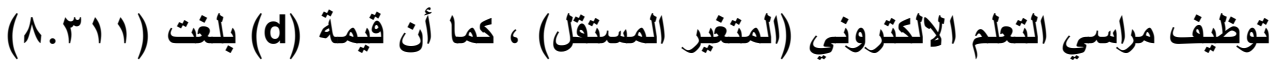
وهي تعبر عن حجم تأثير كبير للمتغير المستقل.

- ارتفاع متوسط درجات الطلاب المعلمين فى التطبيق البعدي عن متوسط درجات التطبيق القبلي في اختبار عمق المعرفة ككل، حيث حصل الطلاب في التطبيق القبلي على متوسط (1 بـ ه 1 )

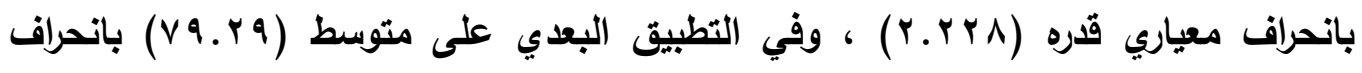

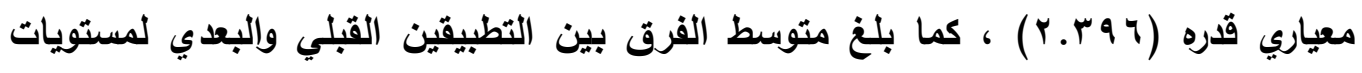

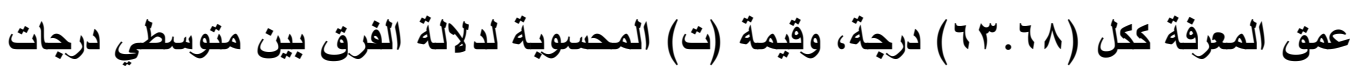
الطلاب المعلمين في التطبيقين القبلي والبعدي لمستويات عمق المعرفة ككل والتي بلغت

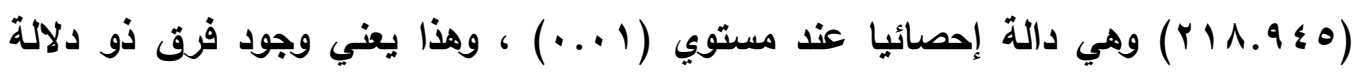
إحصائية بين متوسطي درجات الطلاب في التطبيقين القبلي والبعدي لمستويات عمق المعرفة

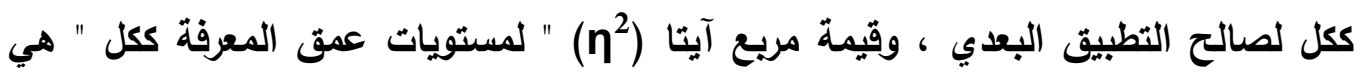

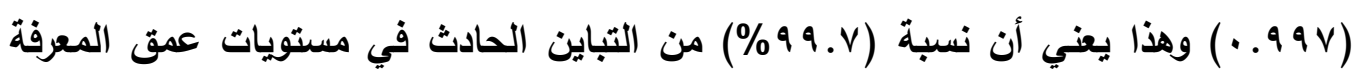
ككل (المتغير التابع) يرجع إلى توظيف مراسي التعلم الاكتروني (المتغير المستقل) ، كما أن أن قيمة (d) بلغت (d (19.01 ) وهي تعبر عن حجم تأثير كبير للمتغير المستقل. وهذا يدل أنه قد حدث نمو واضح ودال في مستويات عمق المعرفة بعد توظيف مراسي التعلم الاكتروني فى تدريس مقرر تقييم تريوى لاى الطلاب المعلمين بكلية الاقتصاد المنزلى.

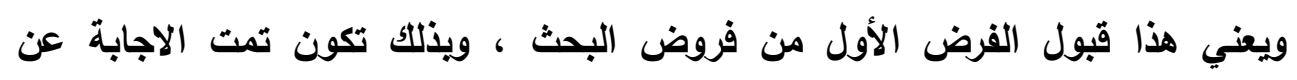
السؤال الثاني للبحث الأى ينص على : " ما أثر توظيف مراسي التعلم الاكتروني في تدريس مقرر تقييم تريوي في تثمية مستويات عمق المعرفة لدي الطالب المعلم بكلية الاقتصاد

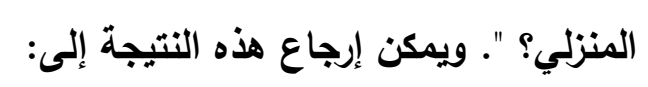

- وفرت مراسى التعلم الاككترونى وما تتضمنه من وسائط متعددة مناخ داعم يثرى عملية

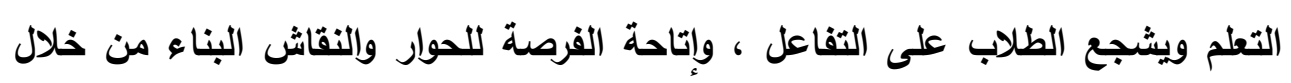

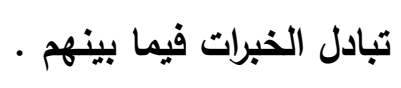

- ما تضمنته مراسى التعلم الاكتروني من وسائط متعددة متمثلة فى مقاطع الفيديو

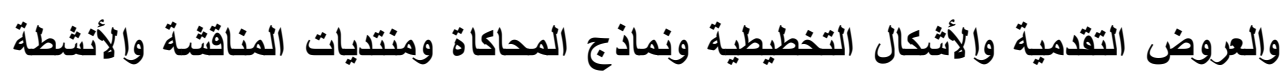
التفاعلية أسهمت فى توفير بيئة تعليمية مثيرة لتعلم مقرر تقييم تريوى وإتاحة الفرصة وائمانة 
للطلاب المعلمين من عرض الثرح وتكراره أكثر من مرة ـ مما كان له أثر واضح فى في زيادة فهم الطلاب للمعلومات والمعارف المتضمنة بالمقرر وتنظيمها واستدعائها وتطبيقها

$$
\text { في المواقف المهنية }
$$

- ساعد التنويع فى المهام والأنثطة والتطبيقات العملية الذى وفرته مراسى التعلم الالكتروني على مستوى موضوعات مقرر تقيم تريوى وتزويد الطلاب بنتائج أدائهم على التى

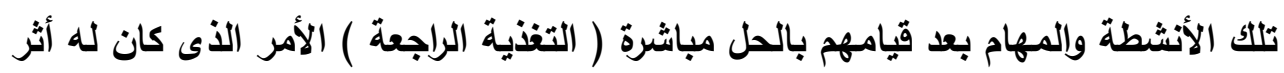

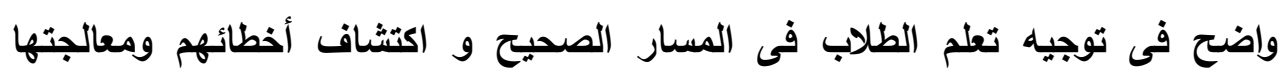

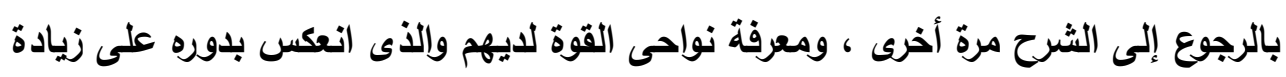

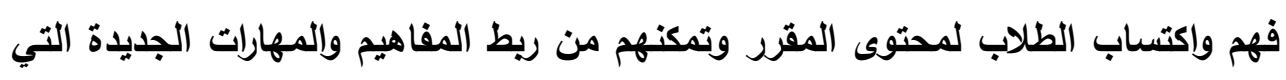

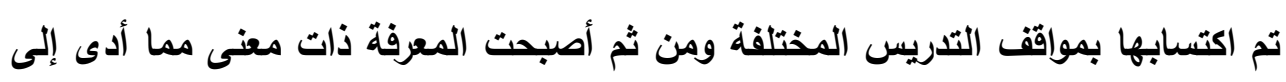

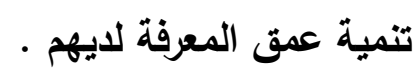
- ما وفرته مراسى التعلم الاكتتروني من مهام وأنثطة تطبيقية عملية متنوعة ومرتبطة

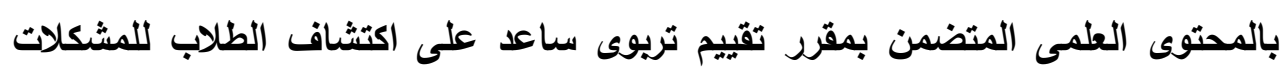

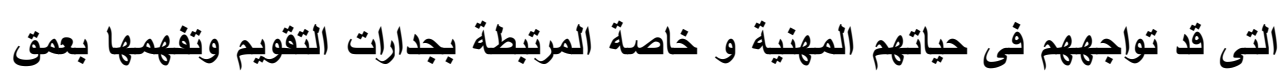

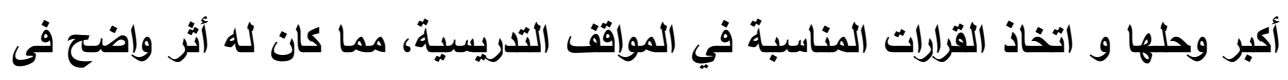

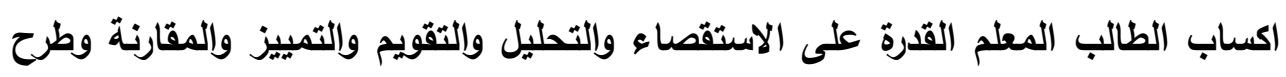

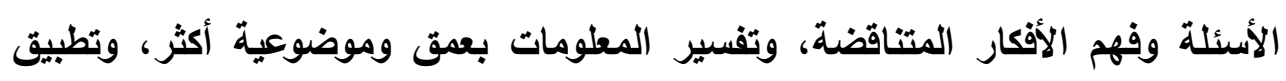

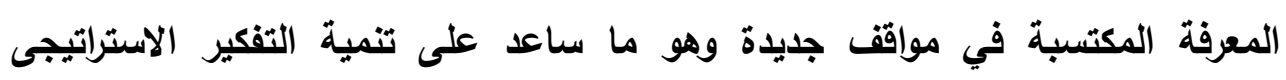

$$
\text { والتفكير الممتد . }
$$

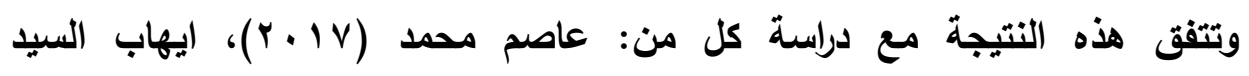

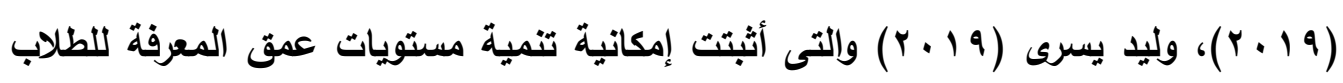

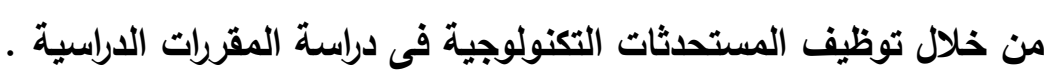

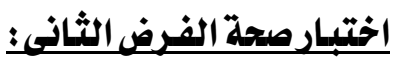

ينص الفرض الثانى من فروض البحث على أنه ":" يوجد فرق دال إحصائياً بين

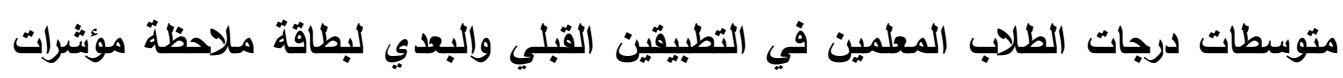

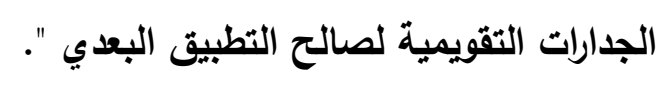


وللتحقق من صحة هذا الفرض تم حساب قيمة (ت) لمتوسطين مرتبطين ومدى دلالتها

للفرق بين متوسطي درجات الطلاب المعلمين في التطبيقين القبلي والبعدي لبطاقة ملاحظة

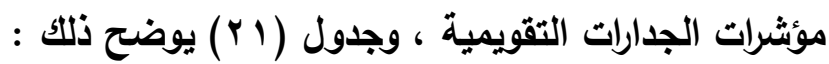

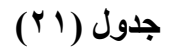

قيمة "ت" ومستوى دلالتها للفرق بين متوسطي درجات الطلاب المعلمين في التطبيقين القبلي والبعدي لبطاقة

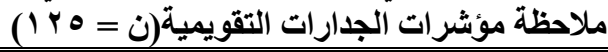

\begin{tabular}{|c|c|c|c|c|c|c|c|c|c|c|c|}
\hline التأثير & قيمة & قيمة & الدلالة & المحسوبة & الدرجية & اللفرياري الاتحراف & المعياري & التطبينين & الحسابي & التطبيق & الأبعاد \\
\hline \multirow[b]{2}{*}{ كبير } & \multirow[b]{2}{*}{$7.1 \mathrm{~V}$} & \multirow[b]{2}{*}{$\because 9 \vee 0$} & \multirow{2}{*}{ مستوي } & \multirow[b]{2}{*}{41.910} & \multirow[b]{2}{*}{ IrE } & \multirow[b]{2}{*}{$7.9 \vee r$} & 7.507 & \multirow[b]{2}{*}{$\varepsilon r . \cdot r$} & $\{\leqslant . \leqslant 1$ & القبلي & \multirow{2}{*}{ ألتخطيط } \\
\hline & & & & & & & \&.va1 & & $A V . \leqslant r$ & البعدي & \\
\hline \multirow{2}{*}{ كبير } & \multirow[t]{2}{*}{$0 . v \circ 9$} & \multirow[t]{2}{*}{$.9 \times 1$} & \multirow{2}{*}{ 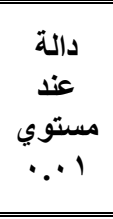 } & \multirow[t]{2}{*}{ TE.rAA } & \multirow[t]{2}{*}{ Irs } & \multirow[t]{2}{*}{$\Lambda . Y 71$} & $\vee . \wedge \vee \varepsilon$ & \multirow[t]{2}{*}{$\varepsilon v . \diamond \wedge$} & $r \wedge . \leqslant 7$ & القبلي & \multirow{2}{*}{ وتنبيقي } \\
\hline & & & & & & & r.97V & & $V{ }^{\prime} \cdot r$ & البعدي & \\
\hline \multirow[b]{2}{*}{ كبير } & \multirow[b]{2}{*}{$v .901$} & \multirow[b]{2}{*}{.910} & \multirow{2}{*}{ مستوي } & \multirow[b]{2}{*}{$\wedge \wedge . \wedge q}$. & \multirow[b]{2}{*}{ TE } & \multirow[b]{2}{*}{$7 . \mathrm{Yqr}$} & O.YYV & \multirow[b]{2}{*}{$0 \cdot . r$} & r.$\wedge r$ & القبلي & \multirow{2}{*}{ تلتبائزي } \\
\hline & & & & & & & r. $\neg \wedge \wedge$ & & $\vee ५ . \wedge \bullet$ & البعدي & \\
\hline \multirow[b]{2}{*}{ كبير } & \multirow[b]{2}{*}{ Ir... } & \multirow[b]{2}{*}{. } & \multirow{2}{*}{ 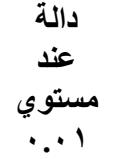 } & \multirow[b]{2}{*}{$\mid T \& . V Y \varepsilon$} & \multirow[b]{2}{*}{ IT } & \multirow[b]{2}{*}{$11.7 v}$. & $1 \cdot .9 \vee 1$ & \multirow[b]{2}{*}{$1 \leq \cdot .7 r$} & 99.79 & القبلي & \multirow[b]{2}{*}{ البطلة } \\
\hline & & & & & & & $\checkmark . \wedge r \checkmark$ & & $r \leq \cdot . r \mid$ & البعدي & \\
\hline
\end{tabular}

يتضح من الجدول السابق ما يلي : - ارتفاع متوسط درجات الطلاب المعلمين فى التطبيق البعدي عن متوسط درجات التطبيق القبلي في بعد جدارة التخطيط ويناء أدوات التقويم ببطاقة ملاحظة مؤثرات الجدارات

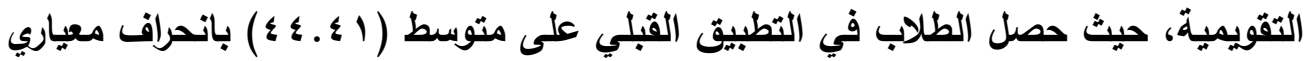

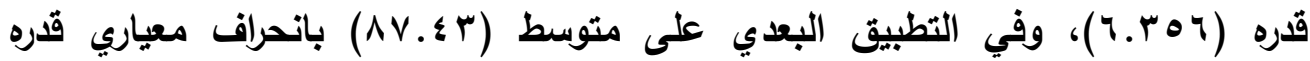

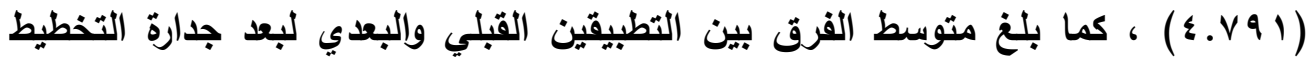
ويناء أدوات التقويم ببطاقة ملاحظة مؤشرات الجدارات التقويمية (r . .ب ع ) درجة، وقيمة (ت) المحسوية لدلالة الفرق بين متوسطي درجات الطلاب المعلمين في التطبيقين القبلي 
والبعدي لبعد جدارة التخطيط ويناء أدوات التقويم ببطاقة ملاحظة مؤشرات الجدارات

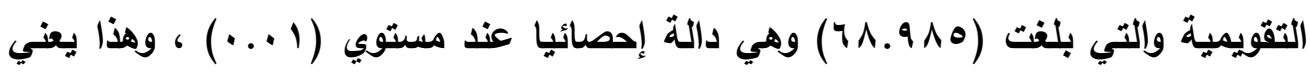
وجود فرق ذو دلالة إحصائية بين متوسطي درجات الطلاب في التطبيقين القبلي والبعدي لبعد جدارة التخطيط ويناء أدوات التقويم ببطاقة ملاحظة مؤشرات الجدارات التقويمية لصاتئ لصاتح التطبيق البعدي ، وقيمة مريع آيتا (n²) " لبعد جدارة التخطيط ويناء أدوات التقويم ببطاقة

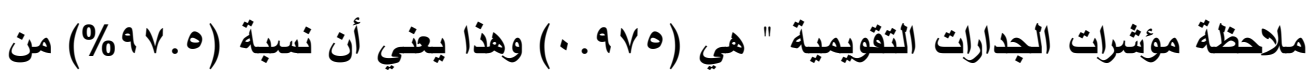
التباين الحادث في بعد جدارة التخطيط ويناء أدوات التقويم ببطاقة ملاحظة مؤشرات الجدارات التقويمية (المتغير التابع) يرجع إلى توظيف مراسي التعلم الاكتروني (المتغير

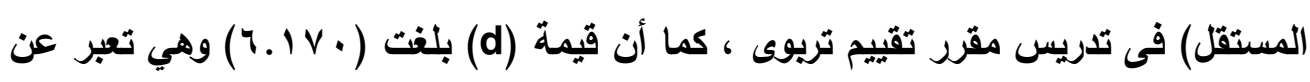
حجم تأثير كبير للمتفير المستقل. - ارتفاع متوسط درجات الطلاب المعلمين فى التطبيق البعدي عن متوسط درجات التطبيق القبلي في بعد جدارة تطبيق وتنفيذ عملية التقويم ببطاقة ملاحظة مؤثرات الجدارات

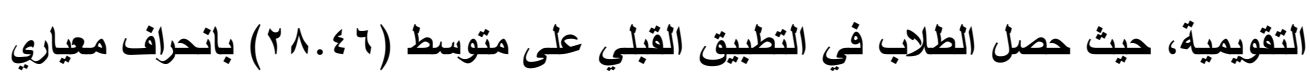

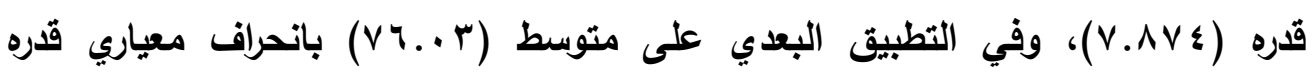

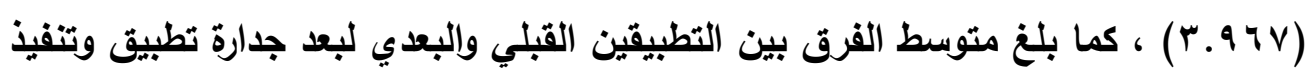

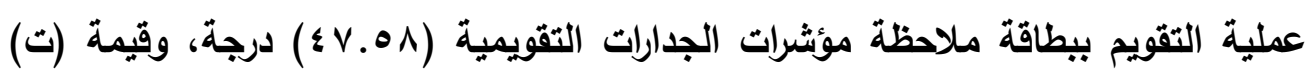
المحسوية لدلالة الفرق بين متوسطي درجات الطلاب المعلمين في التطبيقين القبلي

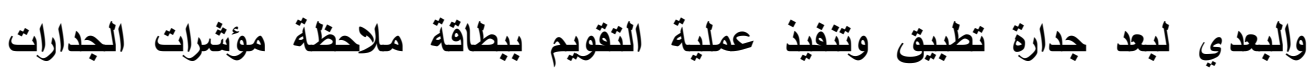

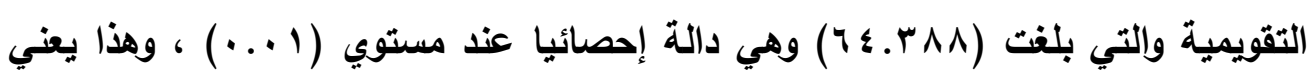
وجود فرق ذو دلالة إحصائية بين متوسطي درجات الطلاب في التطبيقين القبلي والبعدي

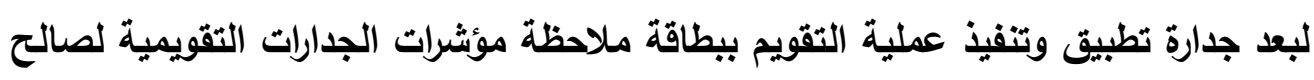
التطبيق البعدي ، وقيمة مريع آيتا (n²) " لبعد جدارة تطبيق وتنفيذ عملية التقويم ببطاقة

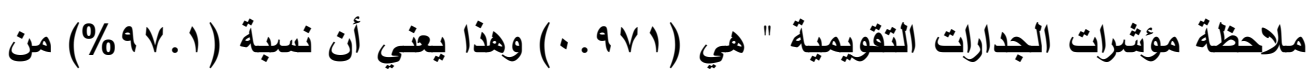
التباين الحادث في بعد جدارة تطبيق وتنفيذ عملية التقويم ببطاقة ملاحظة مؤثرات الجدارات التقويمية (المتغير التابع) يرجع إلى توظيف مراسي التعلم الاكتروني (المتغير 
المستقل) فى تدريس مقرر تقييم تريوى ، كما أن قيمة (d) بلفت (9 ه V. ه ) وهي تعبر عن

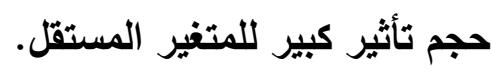

- ارتفاع متوسط درجات الطلاب المعلمين فى التطبيق البعدي عن متوسط درجات التطبيق القبلي في بعد جدارة تحليل وتفسير نتائج التقويم ببطاقة ملاحظة مؤثرات الجدارات

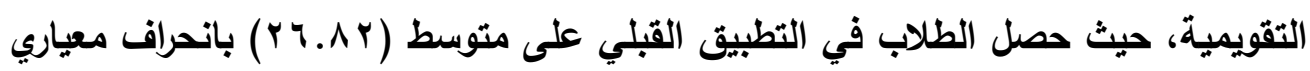

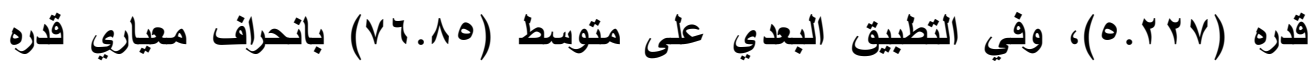

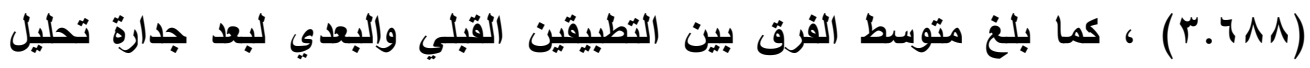

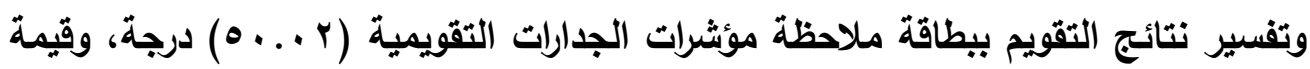
(ت) المحسوية لالالة الفرق بين متوسطي درجات الطلاب المعلمين في التطبيقين القبلي

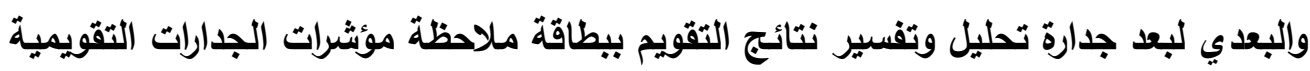

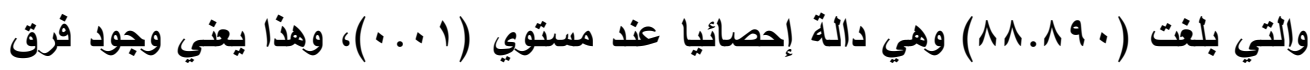
ذو دلالة إحصائية بين متوسطي درجات الطلاب في التطبيقين القبلي والبعدي لبعد جدارة

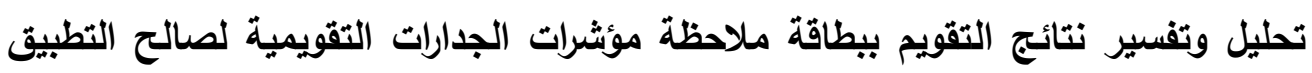
البعدي ، وقيمة مريع آيتا (n²) " لبعد جدارة تحليل وتفسير نتائج التقويم ببطاقة ملاحظة

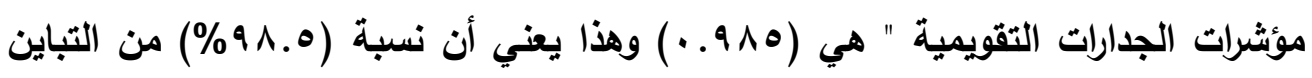
الحادث في بعد جدارة تحليل وتفسير نتائج التقويم ببطاقة ملاحظة مؤثرات الجدارات التقويمية (المتغير التابع) يرجع إلى توظيف مراسي التعلم الاكتروني (المتغير المستقل)

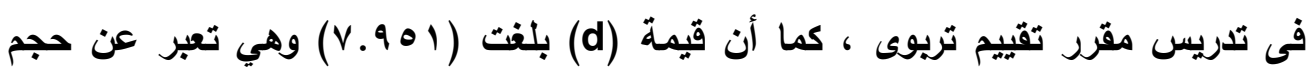

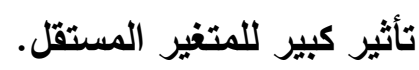
- ارتفاع متوسط درجات الطلاب المعلمين فى التطبيق البعدي عن متوسط درجات التطبيق في بطاقة ملاحظة مؤشرات الجدارات التقويمية ككل، حيث حصل الطلاب في التطبيق القبلي التئي

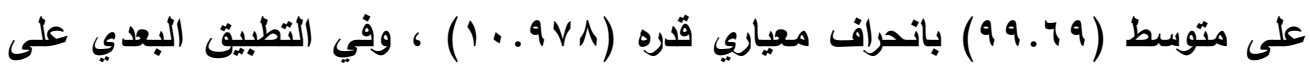

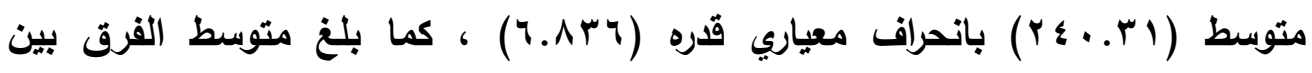

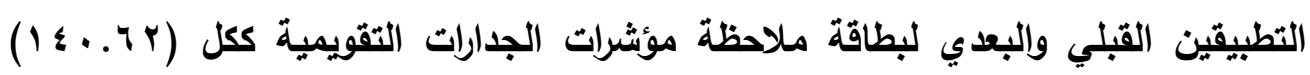

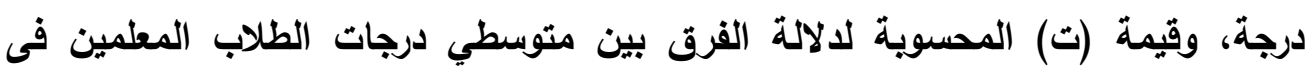
التطبيقين القبلي والبعدي لبطاقة ملاحظة مؤشرات الجدارات التقويمية ككل والتي بلغت 


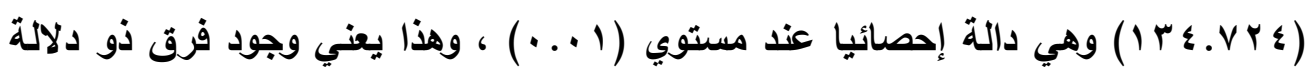
إحصائية بين متوسطي درجات الطلاب في التطبيقين القبلي والبعدي لبطاقة ملاحظة

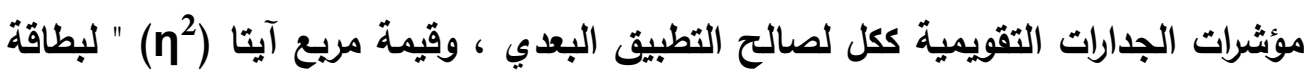

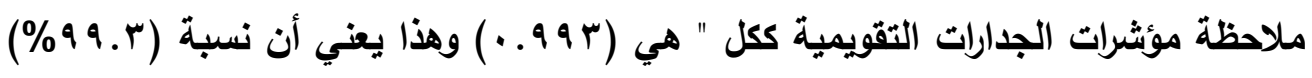
من التباين الحادث في بطاقة ملاحظة مؤثرات الجدارات التقويمية ككل (المتغير التابع) يرجع إلى توظيف مراسي التعلم الاكتروني (المتغير المستقل) فى تدريس مقرر تقييم

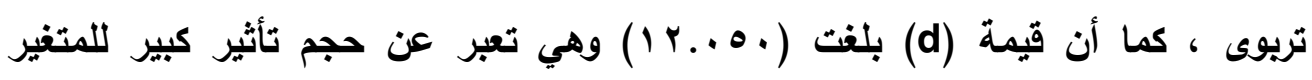
المستقل. ويدل ذلك أنه قد حدث نمو واضح ودال في مؤشرات الجدارات التقويمية بعد توظيف مراسي التعلم الاكتروني فى تدريس مقرر تقييم تريوى لدى الطلاب المعلمين بكلية الاقتصاد

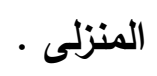

ويعني هذا قبول الفرض الثاني من فروض البحث ، كما أنه يجيب عن السؤال الثالث الذي ينص على : " ما أثر توظيف مراسي التعلم الاكتروني في تدريس مقرر التقييم التريوي

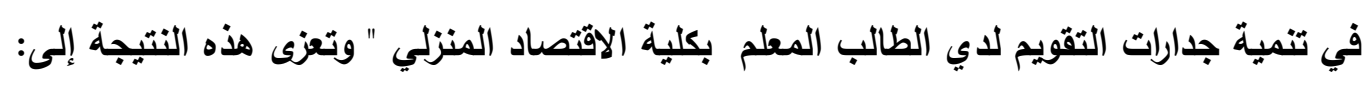
- أدى استخدام مراسى التعلم الالكترونى فى تدريس مقرر تقييم تريوى إلى اتاحة الفرصة للطلاب المعلمين للإطلاع على المحتوى العلمى والمشـاركة فى بنـاء المعارف والمفاهيم من خلال البحث عبر المراسى. والربط بين الجانب النظرى والجانب التطبيقى من خلال

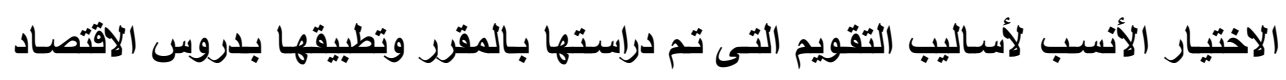

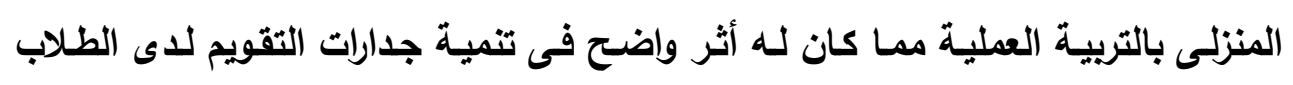
المعلمين. - - ساعدت مراسى التعلم الاكترونى إلى صقل مهارات الطلاب المعلمين وجداراتهم التدريسية

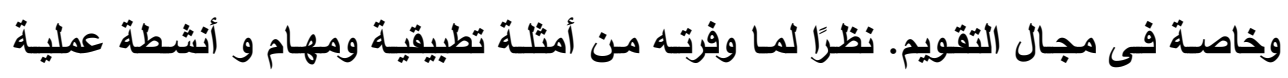

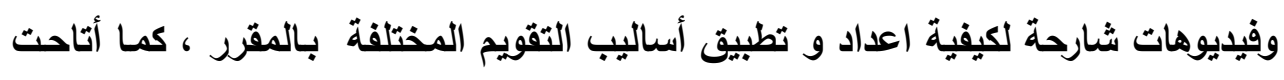
الفرصة إلى جعل الطلاب أقرب إلى واقع مهنتهم المستقبلية فيما يختص بكيفية إعداد إداد وتخطيط الدروس باستخدام أساليب التقويم الحديثة التى تخلم العملية التعليمية مما أدى الدى إلى تنمية جداراتهم التقويمية. 


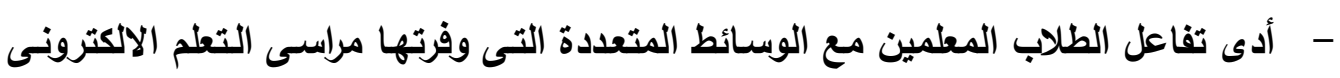

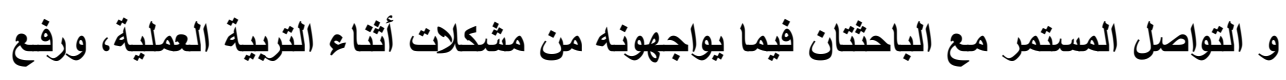
الفيديوهات وملفات (Word) الخاصـة بإعداد وتحضير و نفيذ دروس الاقتصاد المنزلي يولي باستخدام أساليب تقويم متنوعة التى تم التدريب علي استخدامها من خلال تدريس مقرر

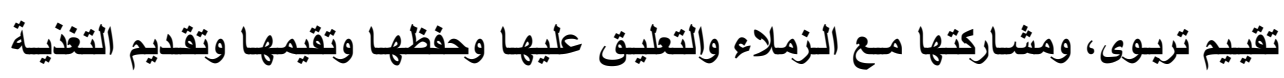
الراجعة من جانب الباحثتان و الزملاء ـ إلى التعرف على مواطن الضعف والقوة فئه فئ أداء

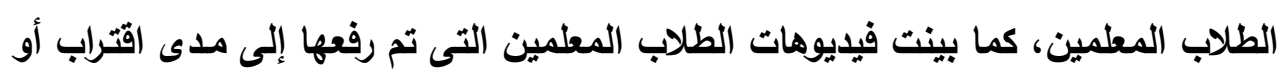
ابتعاد الطلاب المعلمين عن مستوى الأداء الفعلى لاستخدام أسـاليب التقويم عن الأداء

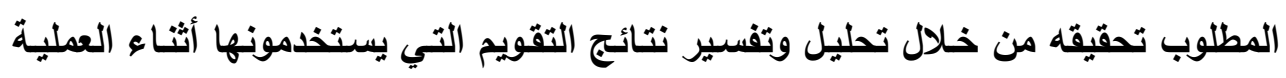
التدريسية. والـذى كـان لـه عظيم الأثر في تنميـة الجـارات التقويميـة الأدائيـة للطلاب المعلمين.

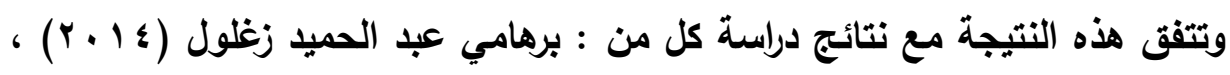

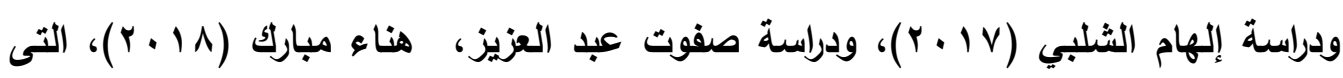

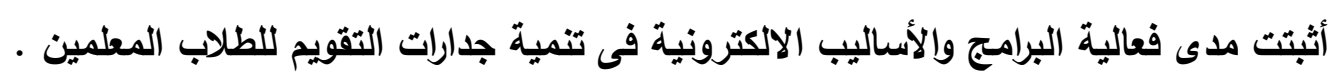

\section{اختبسارصحة الفرض الثالث:}

يـص الفرض الثالث مـن فروض البحث على أنـه: " يوجد فـرق دال إحصـائياً بـين

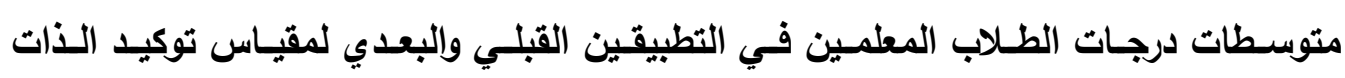
المهنية لصالح التطبيق البعدي ". منوسيطات درجات وللتحقق من صحة هذا الفرض تم حساب قيمة (ت) لمتوسطين مرتبطين ومدى دلالتها للفرق بين متوسطي درجات الطلاب المعلمين في التطبيقين القبلي والبعدي لمقياس توكيد

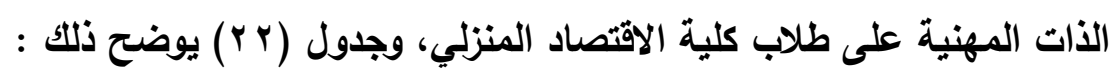




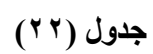

قيمة "ت" ومستوى دلالتها للفرق بين متوسطي درجات الطوات الطلاب المعلمين

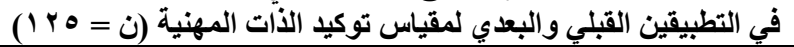

\begin{tabular}{|c|c|c|c|c|c|c|c|c|c|c|c|}
\hline حجث & قيمة & $\begin{array}{r}\text { قيمة } \\
\eta^{2}\end{array}$ & الدلالة & تالمحسوبة & درجات & اللانحراف المعياري & $\begin{array}{r}\text { الانحرياري } \\
\text { ع المعاري }\end{array}$ & متربط الفرق & الحستبي المتيط & التطبيق & الأبعاد \\
\hline \multirow[b]{2}{*}{ كبيز } & \multirow[b]{2}{*}{$v . .99$} & \multirow[b]{2}{*}{$\cdot .911$} & \multirow{2}{*}{ 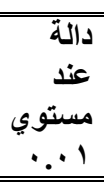 } & \multirow[b]{2}{*}{ Vq.rVY } & \multirow[b]{2}{*}{ Irs } & \multirow[b]{2}{*}{$\varepsilon .77 r$} & r.999 & \multirow[b]{2}{*}{ rr.l. } & r... & القبلي & \multirow[b]{2}{*}{ المعرفي } \\
\hline & & & & & & & rד & & 99.1. & البعدي & \\
\hline \multirow{2}{*}{ كبير } & \multirow{2}{*}{ r.qrA } & \multirow{2}{*}{$\because 9 \leq$} & \multirow{2}{*}{ عالة } & \multirow{2}{*}{$\varepsilon \varepsilon . r r$} & \multirow{2}{*}{$1 Y \leq$} & \multirow{2}{*}{$7 . \wedge 00$} & $0 . \leqslant 94$ & \multirow{2}{*}{$r 7.99$} & $\leqslant r . q$. & القبلي & البعد \\
\hline & & & & & & & 0.491 & & $v \cdot . \wedge q$ & البعدي & \\
\hline \multirow{2}{*}{ كبير } & \multirow{2}{*}{$r . \vee \vee q$} & \multirow{2}{*}{$\because 9 r 0$} & \multirow{2}{*}{ عالة } & \multirow{2}{*}{$\varepsilon r . r \circ r$} & \multirow{2}{*}{$1 Y \leq$} & \multirow{2}{*}{$1 \cdot . \leqslant \leqslant V$} & $\varepsilon .0 r$. & \multirow{2}{*}{$r 9 . \leqslant 1$} & $\varepsilon \vee . \diamond \wedge$ & القبلي & \multirow{2}{*}{ المهند الأداء } \\
\hline & & & & & & & $1 . .119$ & & Av. .7 & البعدي & \\
\hline \multirow{2}{*}{ كبيز } & \multirow{2}{*}{$r .1 \cdot r$} & \multirow{2}{*}{$\because 9 \cdot v$} & \multirow{2}{*}{ عالة } & \multirow{2}{*}{$r \varepsilon . T V V$} & \multirow{2}{*}{$1 Y \leq$} & \multirow{2}{*}{$9.1 \leq 7$} & צ.Arr & \multirow{2}{*}{$r \wedge . r v$} & Vr.ru & القبلي & \multirow{2}{*}{ الشالاجصدي } \\
\hline & & & & & & & $\varepsilon . V \vee \varepsilon$ & & $1.1 . v \leq$ & البعدي & \\
\hline \multirow{2}{*}{ كبير } & $17 \%$ & - $y r \Delta$ & عالة & IA rrV & 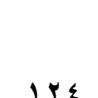 & $1 \pi<4$ & 11.4 ד & 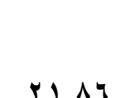 & IV.rs & القبلي & \\
\hline & .11. & $\because 2 \pi$ & ا... مستوي & $1 \mathrm{~T} . \mathrm{TV}$ & 118 & 11.2 .6 & Y.OA & 1.0 & rq.r. & البعدي & \\
\hline كبسر & $r \quad 1 \leqslant r$ & .9 .9 & عالة & rol r & $1 Y \varepsilon$ & $97 \%$ & \&.r... & $r \cdot \Lambda r$ & $11 . \cdot 1$ & القبلي & بعد الطموح \\
\hline & & & ا •.. مسنوي & & & & r.r.so & & rᄉ. 9. & البعدي & \\
\hline كبر & $0 \leqslant \leqslant \wedge$ & . 971 & عالة & $7.91 \varepsilon$ & $1 Y \varepsilon$ & \& וr & $19.8 \leqslant$ & 18.71 & ג r & القبلي & المقياس \\
\hline & & & ا •.. مستوي & & & & 17.771 & & $\varepsilon .7 . \wedge 9$ & البعدي & \\
\hline
\end{tabular}

يتضح من الجدول السابق ما يلي :

- ارتفاع متوسط درجات الطلاب المعلمين فى التطبيق البعدي عن متوسط درجات التطبيق القبلي

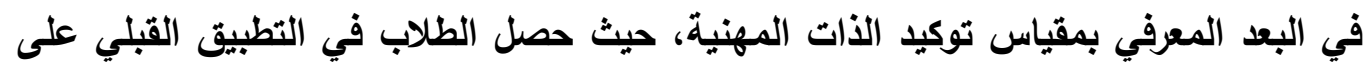

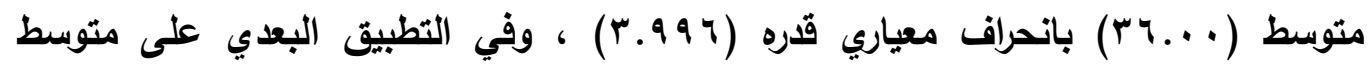




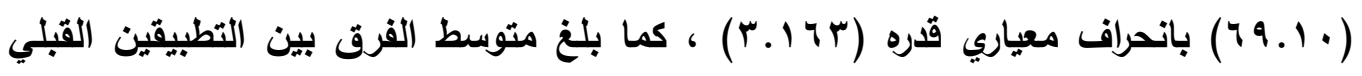

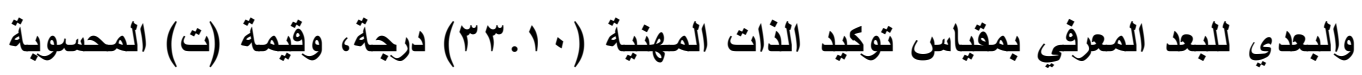
لالالة الفرق بين متوسطي درجات الطلاب المعلمين في التطبيقين القبلي والبعدي للبعد

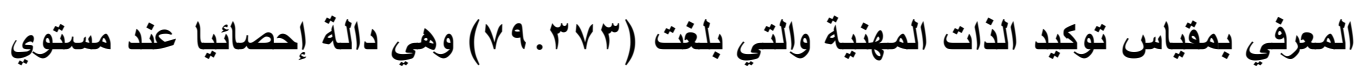
(1 (.) ، وهذا يعني وجود فرق ذو دلالة إحصائية بين متوسطي درجات الطلاب في توكي

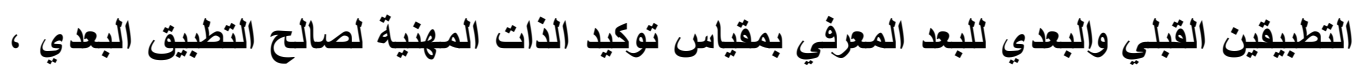

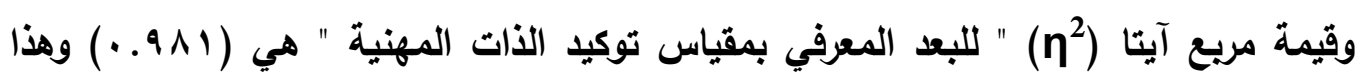

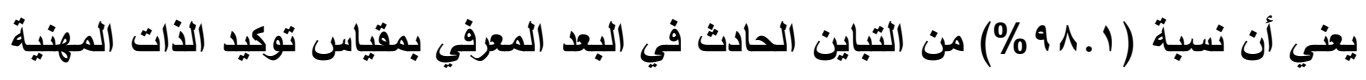
(المتغير التابع) يرجع إلى توظيف مراسي التعلم الاكتروني (المتغير المستقل) فى تدريس

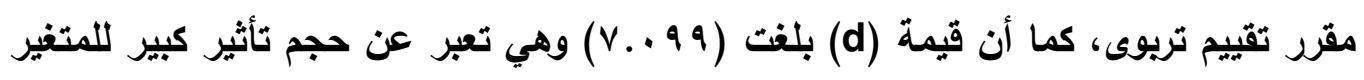
المستقل.

ارتفاع متوسط درجات الطلاب المعلمين فى التطبيق البعدي عن متوسط درجات التطبيق القبلي

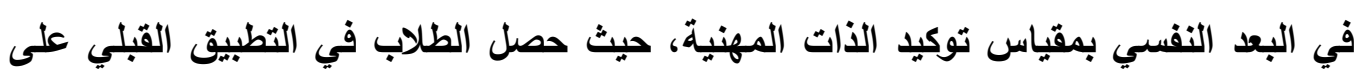

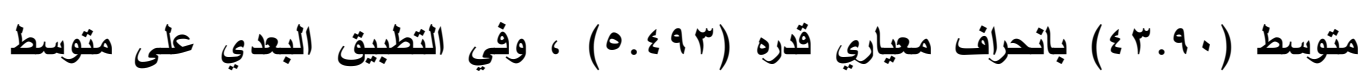

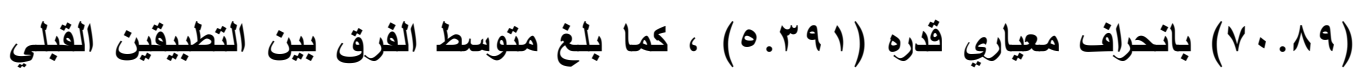

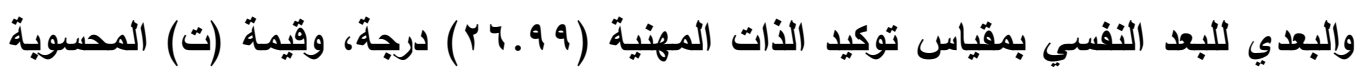
لالالة الفرق بين متوسطي درجات الطلاب المعلمين في التطبيقين القبلي والبعدي للبعد

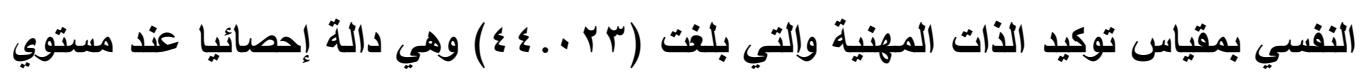

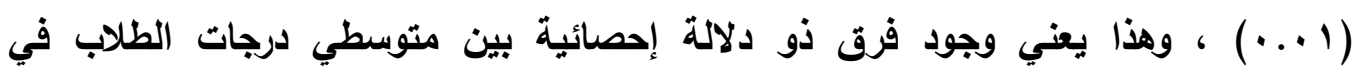

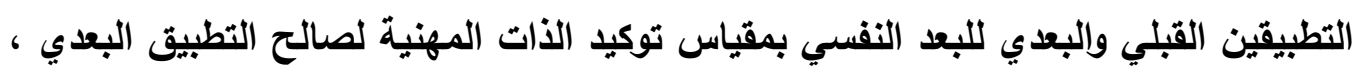

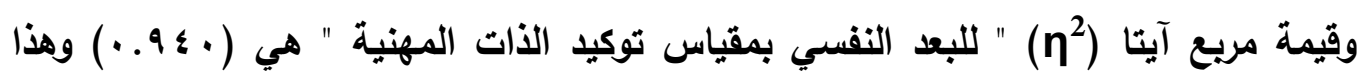
يعني أن نسبة ( ..؛ 9\%) من التباين الحادث في البعد النفسي بمقياس توكيد الذات المهنية (المتفير التابع) يرجع إلى توظيف مراسي التعلم الاكتروني (المتغير المستقل) فى تدريس

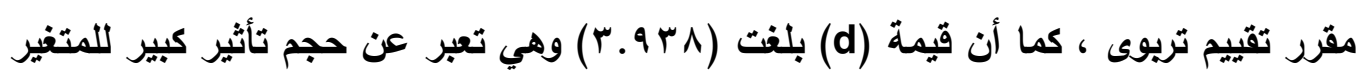
المستقل. 
- ارتفاع متوسط درجات الطلاب المعلمين فى التطبيق البعدي عن متوسط درجات التطبيق القبلي في بعد الأداء المهني بمقياس توكيد الذات المهنية، حيث حصل الطلاب في التطبيق القبلي التئي

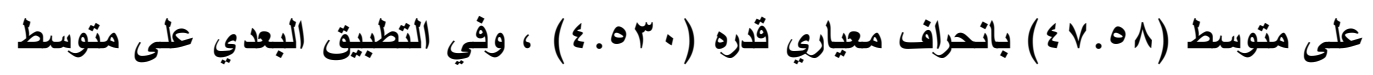

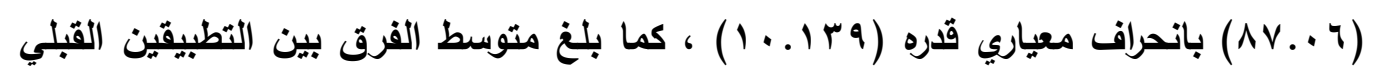

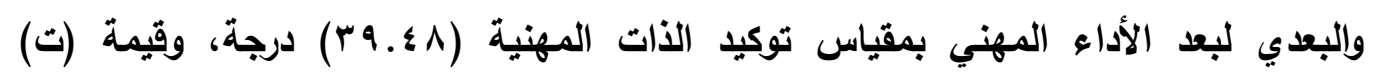

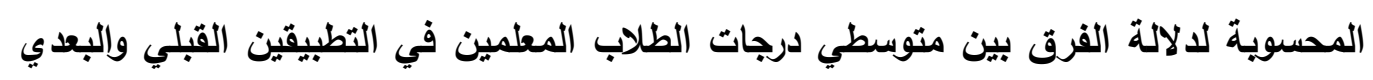

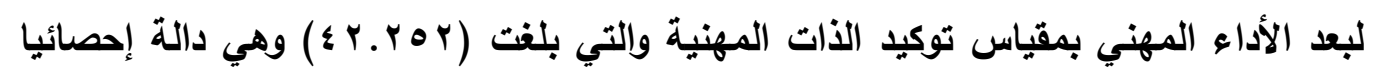
عند مستوي (1 . . . ) ، وهذا يعني وجود فرق ذو دلالة إحصائية بين متوسطي درجات الطلاب

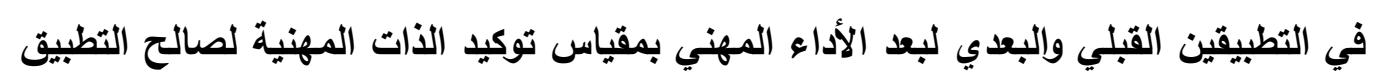

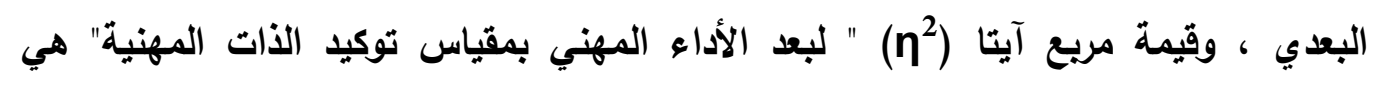

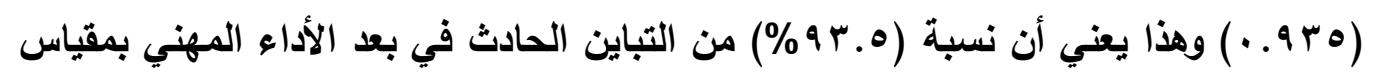
توكيد الأات المهنية (المتغير التابع) يرجع إلى توظيف مراسي التعلم الاكتروني (المتغير

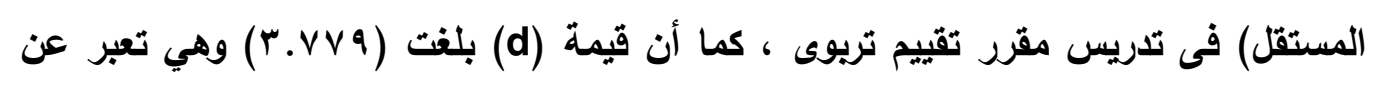
حجم تأثير كبير للمتغير المستقل.

ارتفاع متوسط درجات الطلاب المعلمين فى التطبيق البعدي عن متوسط درجات التطبيق القبلي

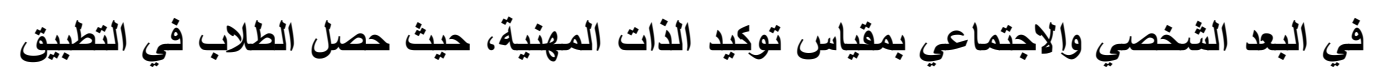

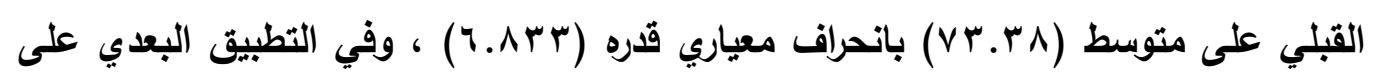

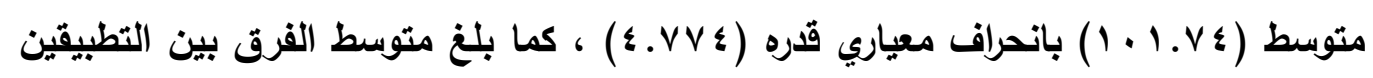

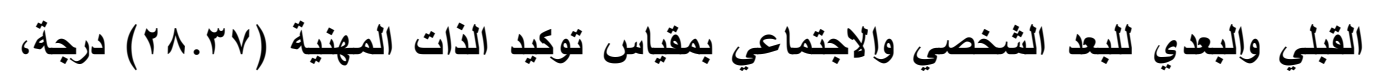
وقيمة (ت) المحسوية لالالة الفرق بين متوسطي درجات الطلاب المعلمين في التطبيقين

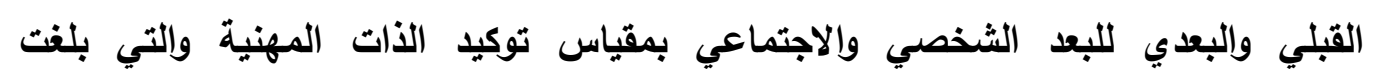
(r.7VV)

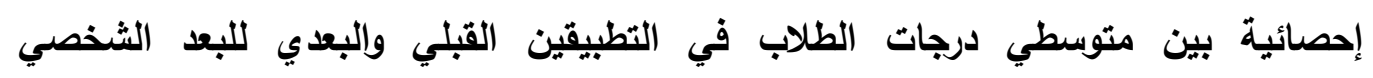

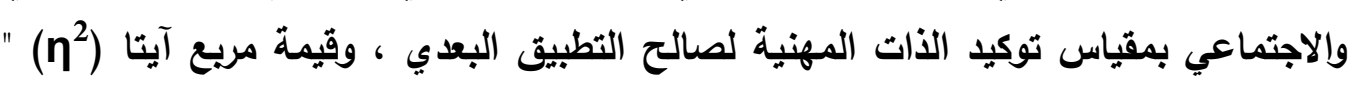

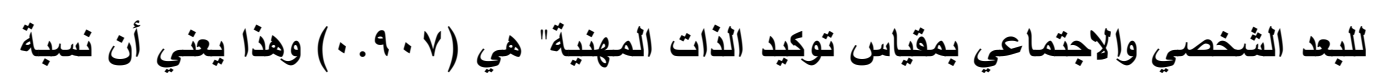

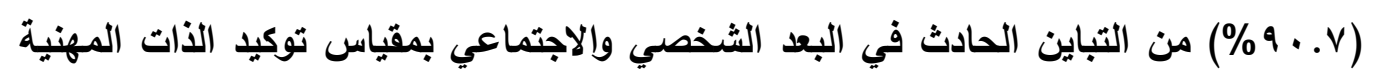


(المتغير التابع) يرجع إلى توظيف مراسي التعلم الاكتروني (المتغير المستقل) فى تدريس

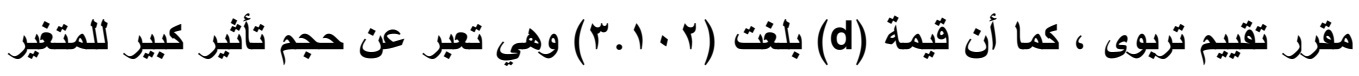
المستقل.

- ارتفاع متوسط درجات الطلاب المعلمين فى التطبيق البعدي عن متوسط درجات التطبيق القبلي في البعد القيمي بمقياس توكيد الذات المهنية، حيث حصل الطلاب في التطبيق القبلي على

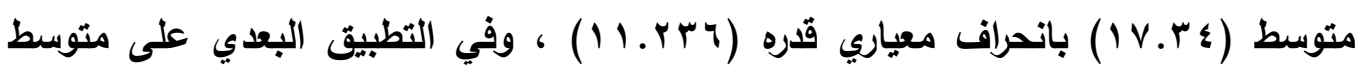

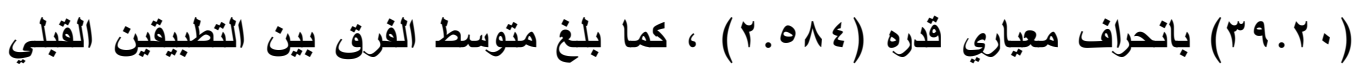

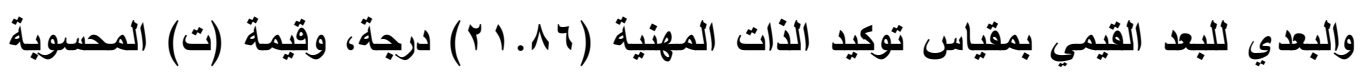
لالالة الفرق بين متوسطي درجات الطلاب المعلمين في التطبيقين القبلي والبعدي للبعد القيمي

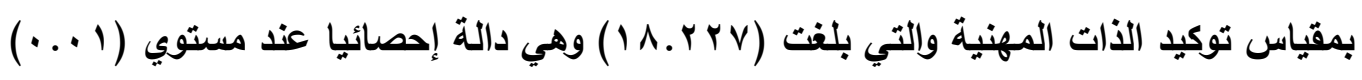
، وهذا يعني وجود فرق ذو دلالة إحصائية بين متوسطي درجات الطلاب في التطبيقين القبلي

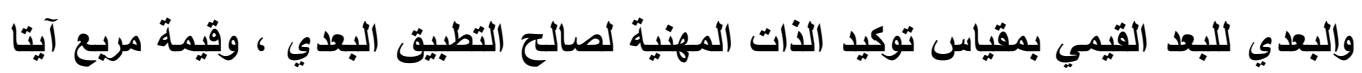

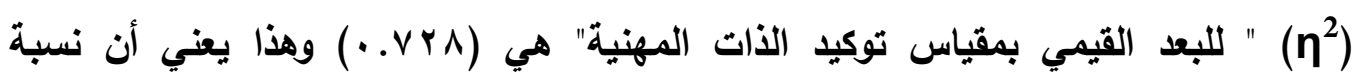
(\% من التباين الحادث في البعد القيمي بمقياس توكيد الأات المهنية (المتغير التابع) يرجع إلى توظيف مراسي التعلم الاكتروني (المتغير المستقل) فى تدريس مقرر تقييم تربوى ،

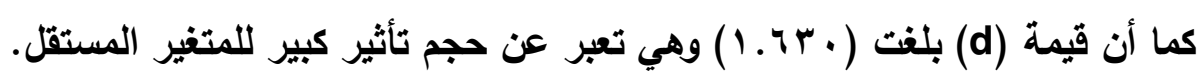
ارتفاع متوسط درجات الطلاب المعلمين فى التطبيق البعدي عن متوسط درجات التطبيق القبلي في بعد الطموح المستقبلي بمقياس توكيد الذات المهنية، حيث حصل الطلاب في التطبيق

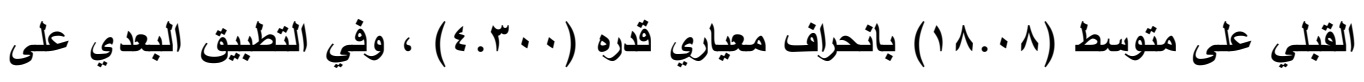

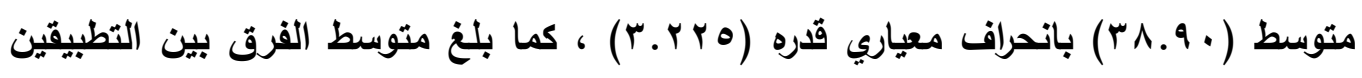

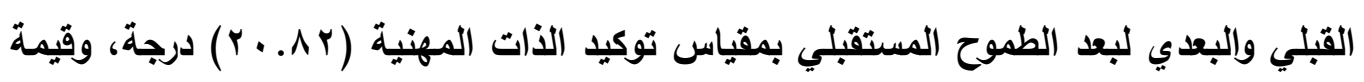
(ت) المحسوية لدلالة الفرق بين متوسطي درجات الطلاب المعلمين في التطبقين القبلي

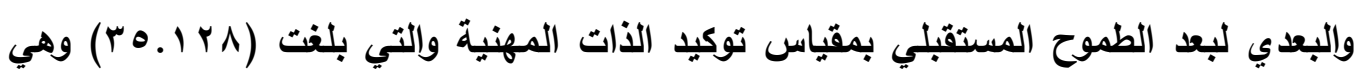
دالة إحصائيا عند مستوي ( (1. . .) ، وهذا يعني وجود فرق ذو دلالة إحصائية بين متوسطي

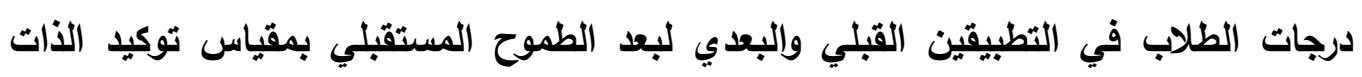

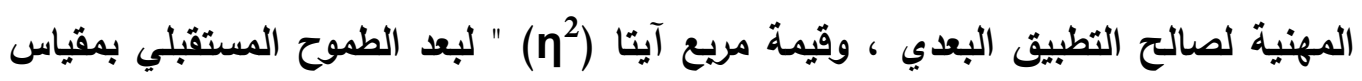


توكيد الذات المهنية" هي (9 .9. • ) وهذا يعني أن نسبة (9 . .9\%) من التباين الحادث في بعد الطموح المستقبلي بمقياس توكيد الذات المهنية (المتغير التابع) يرجع إلى توظيف مراسي التي التعلم الاكتروني (المتغير المستقل) فى تدريس مقرر تقييم تريوى ، كما أن قيمة (d) بلغت إلت توطي

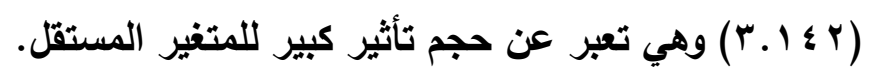

- ارتفاع متوسط درجات الطلاب المعلمين فى التطبيق البعدي عن متوسط درجات التطبيق القبلي لطلاب المجموعة التجريبية في مقياس توكيد الذات المهنية ككل، حيث حصل الطلاب في

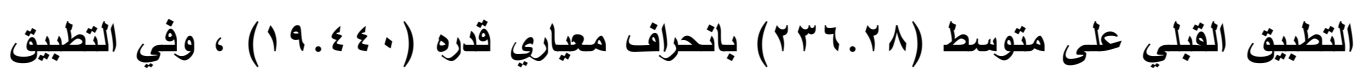

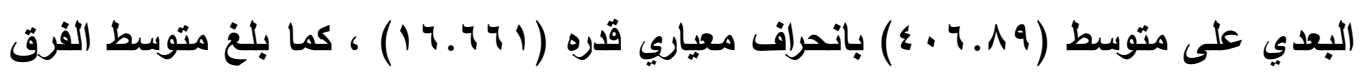

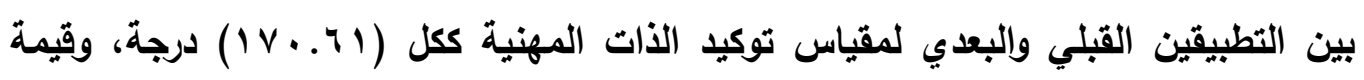
(ت) المحسوية لالاية الفرق بين متوسطي درجات طلاب المجموعة التجريبية في التطبيقين

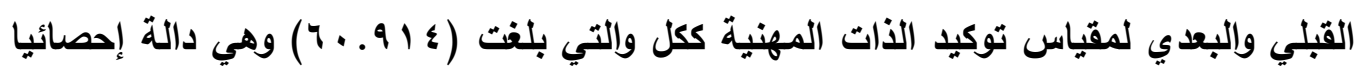
عند مستوي ( ( . . ) ، وهذا يعني وجود فرق ذو دلالة إحصائية بين متوسطي درجات الطلاب

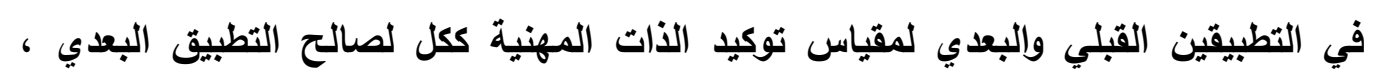

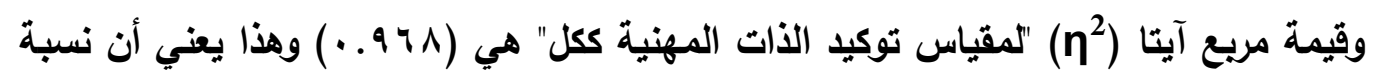

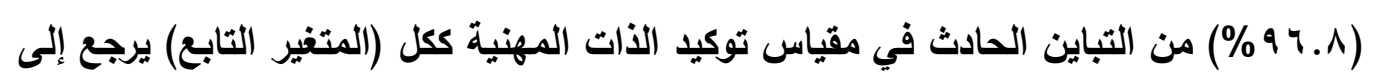

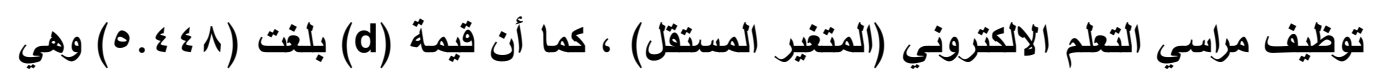
تعبر عن حجم تأثير كبير للمتغير المستقل.

ويدل ذلك أنه قد حدث نمو واضح ودال في أبعاد مقياس توكيد الذات المهنية بعد توظيف

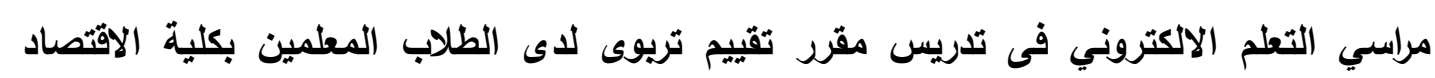
المنزلى

ويعني هذا قبول الفرض الثالث من فروض البحث ، كما تمت الاجابة عن السؤال الرابع الذي ورد في البحث الذى ينص على : " ما أثر توظيف مراسي التعلم الاكتروني في تدريس مقرر

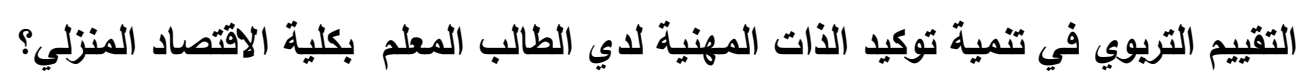
وترجع الباحثتان هذه النتيجة الي : تلنئ توكئ 
- ساعد توظيف مراسي التعلم الالكترونية في السياق التعليمي علي تتمية الجانب المعرفي

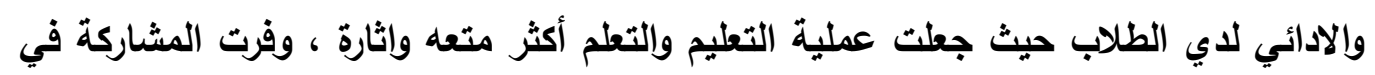

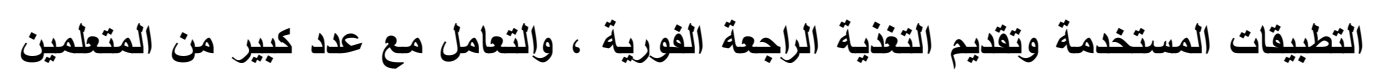

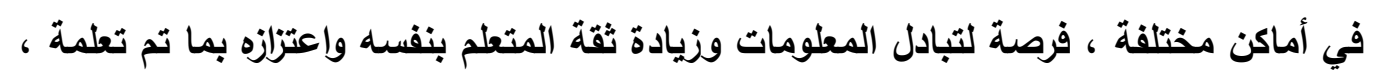

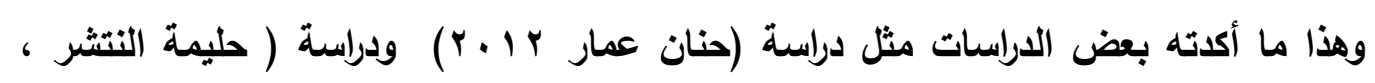

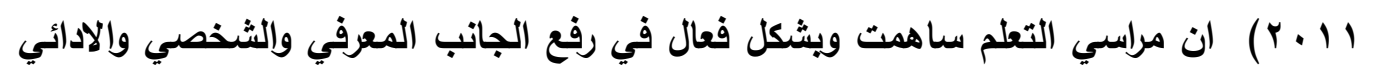
المهني لاي الطلاب المعلمين. ما وفرته مراسي التعلم من مناقثات الجماعية اثناء استخدام منتديات المناقشة أو من خلال تطبيق الوتس آب Wats App اتاح الفرصة بين المتعلمين للتواصل والمشاركة مما كان لله

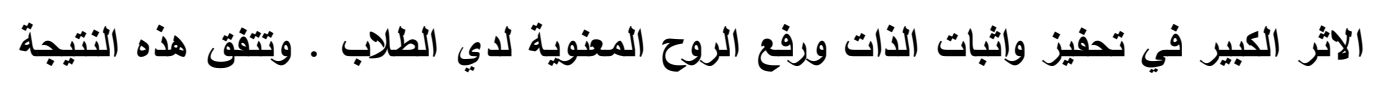

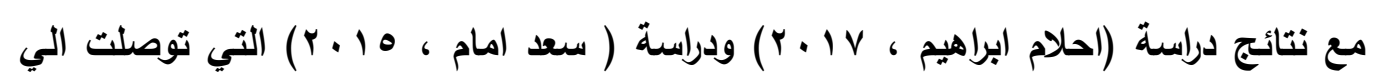

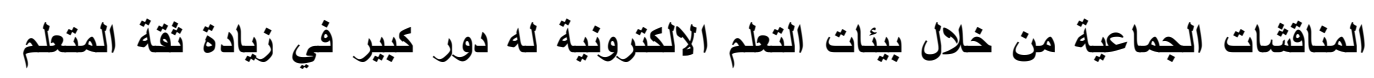
بذاته ويظهر ذلك اثثاء ممارسته العملية التدريسية.

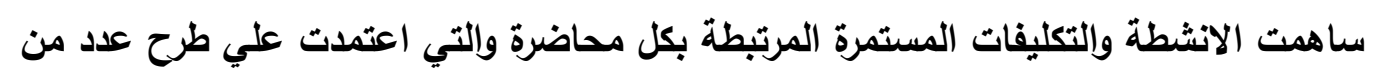

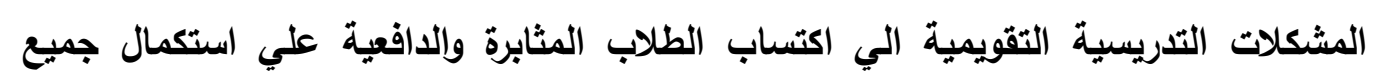
الانشطة وتقديم المزيد من التفسيرات والملاحظات البنائة ، وتبادل المعلومات والخبرات بين الطلاب وتقبل الرآي والرآي الآخر ، وإثراء التفاعل بين الطلاب والمحتوي التعليمي مما ادي الي اكتساب الطلاب الثقة بالنفس وتمكنهم من الخبرات المعرفية التي ارتبطت بمهارات التقويم

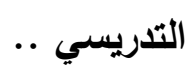

\section{اختبـار صحة الفرض الرابع:}

ينص الفرض الرابع من فروض البحث أنه : "يوجد علاقة ارتباطية بين نمو مستويات عمق

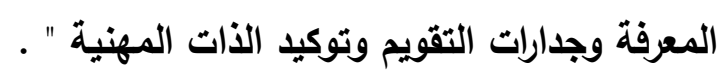

وللتحقق من صحة هذا الفرض تم حساب قيمة معامل ارتباط بيرسون Pearson وجنوات بين درجات الطلاب المعلمين في التطبيق البعدي على اختبار مستويات عمث المعرفة ، ودرجاتهم على بطاقة ملاحظة وجدارات التقويم، وكذلك درجاتهم على مقياس توكيد الذات

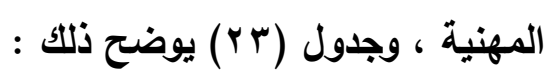




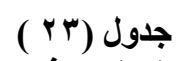

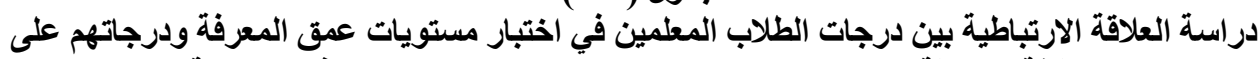

\begin{tabular}{|c|c|c|c|c|c|}
\hline اتجاه العلاقة & مدلى قوة & الدلالة & قالارتباط معامل (ر) & أطراف العلاقة & العدد \\
\hline طوجية & العلاقة قوية & $\because \cdot 1$ & $\because .9 \vee \wedge$ & جستويات عمق المعرفة & Tro \\
\hline طوجبة & العلاقة قوية & $\because \cdot 1$ & .911 & مستويات عمق المعرفة & 1ro \\
\hline طوجبة & العلاقة قوية & $\because \cdot 1$ & $\cdot . \wedge \uparrow \Lambda$ & 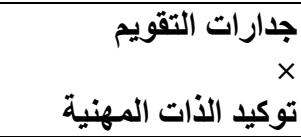 & Tro \\
\hline
\end{tabular}

يتضح من الجدول السابق ما بالي:

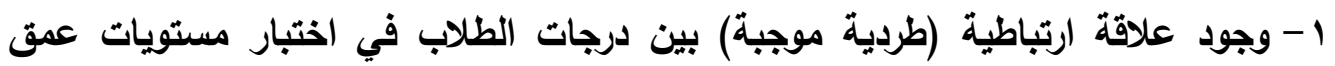
المعرفة ودرجاتهم في بطاقة ملاحظة جدارات التقويم؛ حيث بلغت قيمة معامل ارتباط دودئ دودئ

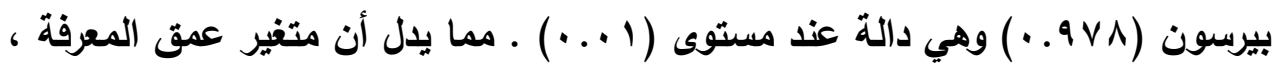
ومتغير جدارات التقويم مرتبطين ارتباط طردي قوي فيتزايدا الاثنين معا ويتناقصا معا. والثكل (•) يوضح ذلك

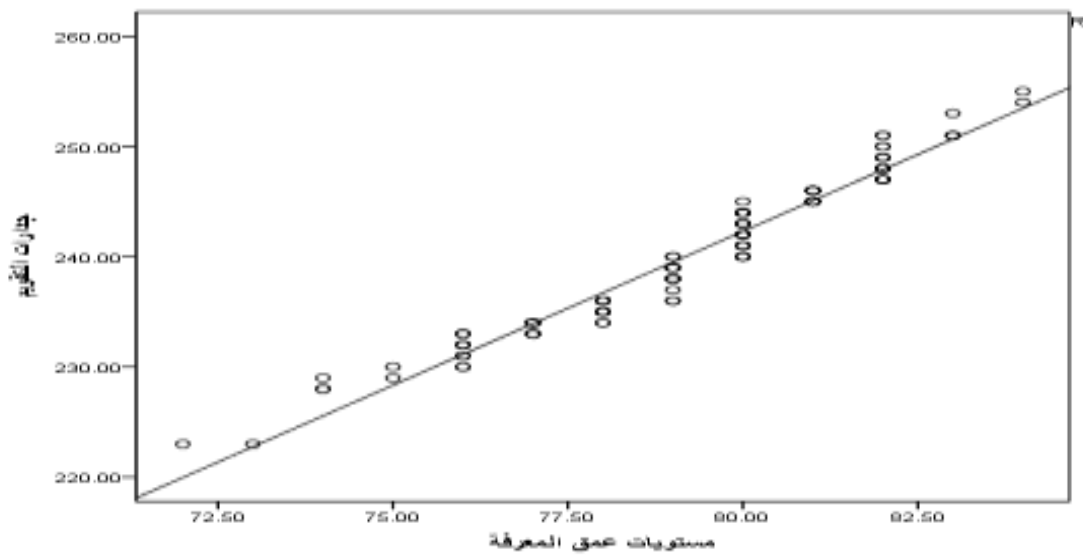

شكل (•) العلاقة الارتباطية بين درجات الطلاب المعلمين في اختبار مستويات عمق المعرفة ودرجاتهم في بطاقة ملاحظة جدارات التقوي التباري

r - وجود علاقة ارتباطية (طربية موجبة) بين درجات الطلاب في اختبار مستويات عمق بلق

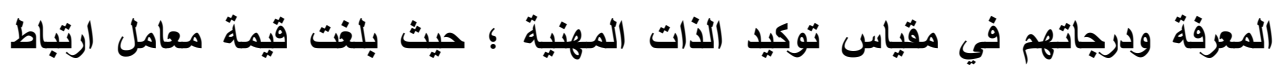
بيرسون (11 (11.) وهي دالة عند مستوى (1 ...) . حيث أن متغير عمق المعرفة ، 
ومتغير توكيد الذات المهنية مرتبطين ارتباط طردي قوي فيتزايدا الاثنين معا ويتناقصا معا. والثكل البياني التالي (7) يوضح ذلك :

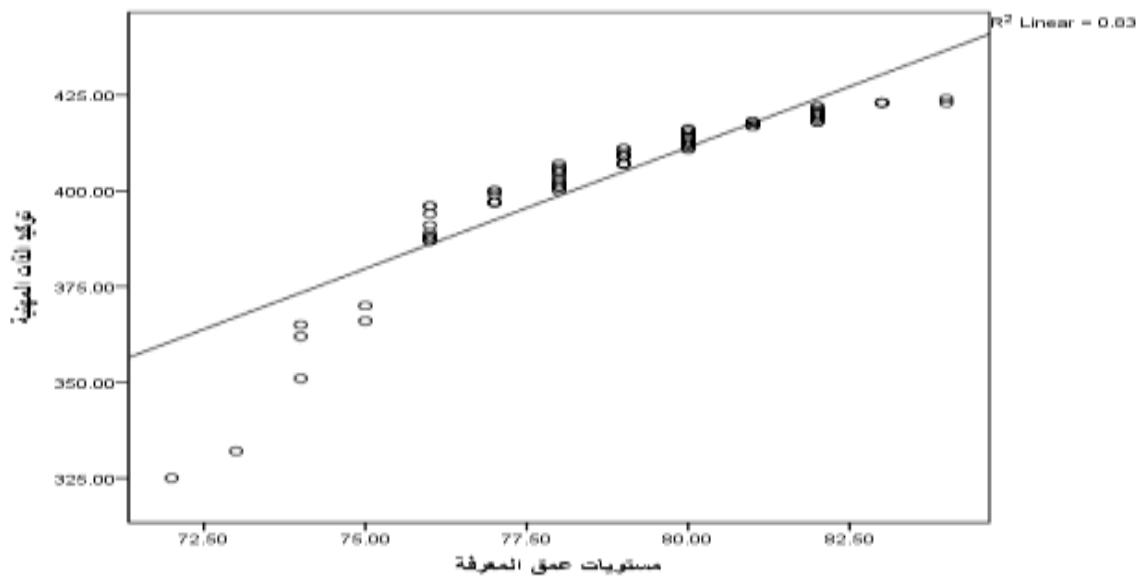

شكل (†)العلاقة الارتباطية بين درجات طلاب المجموعة التجريبية في اختبار مستويات عمق المعرفة ودرجاتهم في مقياس توكيد الذات المهنية

r- وجود علاقة ارتباطية (طردية موجبة) بين درجات الطلاب في بطاقة ملاحظة جدارات التقويم ودرجاتهم في مقياس توكيد الذات المهنية ؛ حيث بلغت قيمة معامل ارتباط

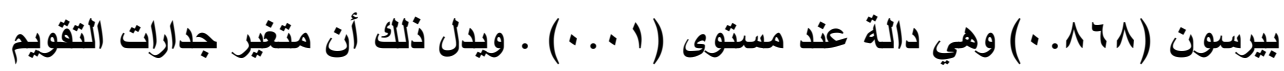

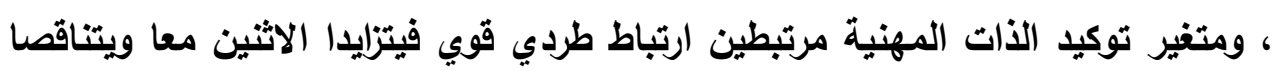

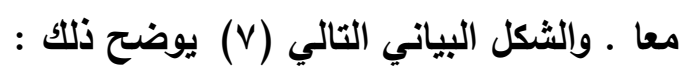

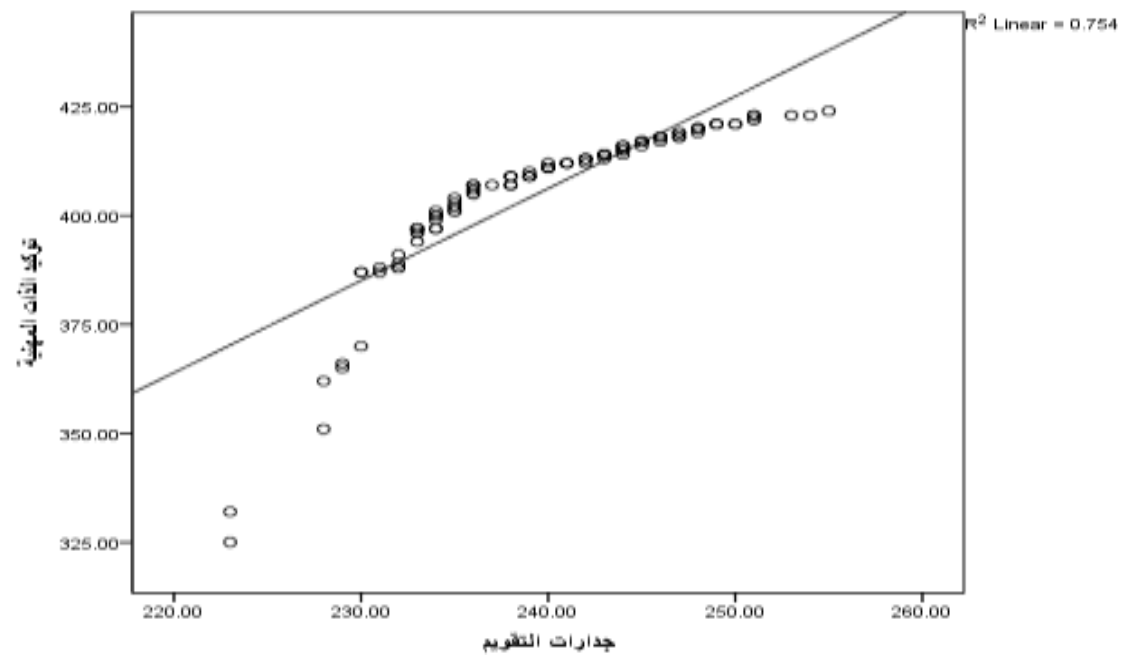

شكل (V)(العلاقة الارتباطية بين درجات الطلاب المعلمين في بطاقة ملاحظة جدارات التقويم ودرجاتهم في مقياس توكيد الذات المهنية 
ويدل هذا إلى وجود علاقة طردية قوية بين مستويات عمق المعرفة وجدارات التقويم وتوكيد الاتات المهنية لدي الطلاب المعلمين (عينة البحث) .

ويعني هذا قبول الفرض الرابع من فروض البحث ، كما أنه تمت الاجابة عن السؤال الخامس الذي ورد في البحث والذى ينص على:" ما العلاقة بين مستويات عمق المعرفة وجدرات التقويم وتوكيد الذات المهنية لدي الطالب المعلم بكلية الاقتصاد المنزلي؟

\section{وترجع الباحثثان هذه النتيجة الي :}

- - اتاح توظيف مراسي التعلم الاكترونية الي زيادة فرص التواصل الاجتماعي وتبادل الآراء وإلتعليقات والخبرات ، ومساعدة الطلاب بعضهم البعض في توضيح العديد من العناصر

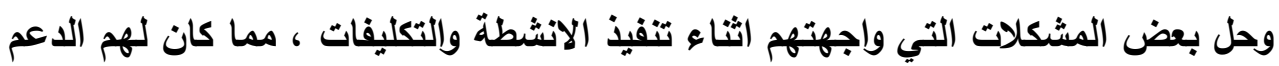
في بذل المزيد من الجهد ل فهم الموضوعات والتعمق فيها ، من خلال مشاهدة اعمال اقرانهم عبر مراسي التعلم ، مما زادت ثقة المتعلم بذاته نتيجة لفهمه العميق للمحتوي التعليمي وهذا ما أكدته دراسة ( Chapman, 2014 (Ch). - كما تتسم بيئة التعلم الاكترونية القائمة علي مراسي التعلم بالمرونة مع توفير فرص التعلم في أي وقت وأي مكان ، وإمكانية الرجوع الي المحتوي التعليمي عدة مرات ، مما باله

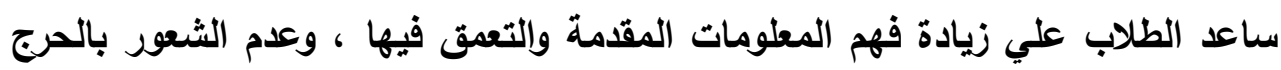

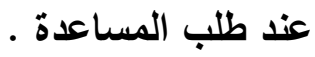
- عندما تزداد ثقة الفرد علي إدارة الموقف وتحمل الاعباء ومواجهة التحديات والحرص علي تحقيق الاهداف المنشود ، تزداد دافعيته نحو فهم المعلومات وتحليلها وتفسير نتائج التقويم التي يستخدمونه أثناء العملية التدريسية كما تتولد لاية طموح في التجاح

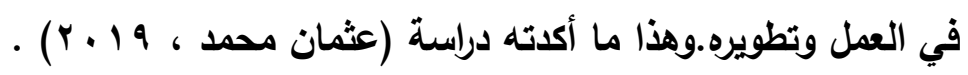




\section{توصيات البحث:}

استنادا إلى ما توصل إليه البحث من نتائج تم وضع عدد من التوصيات أهمها: - التوسع فى توظيف التعلم الالكتروني فى تدريس المقررات التخصصية للطلاب المعلمين فى كافة التخصصات، ويخاصة المقررات المتعلقة بتنمية جداراتهم التدريسية. لتعظيم الاستفادة من وقت التعلم فى تطوير قدارتهم وثقتهم المهنية. - الاهتمام بالدورات التدريبية وورش العمل في مجال التقويم التريوي للمعلمين قبل وأثناء الخدمة لاكتسابهم مهارات اعداد ويناء أساليب التقويم المختلفة مما ينعكس على جودة العملية التعليمية . - تطوير أنظمة التذريب الخاصة بأعضاء هيئة التدريس والاعتماد علي نظم التعليم الإكتروني عن بعد ، لتحقيق اهداف التنمية المهنية المستدامة وتحقيق اهدا العملية

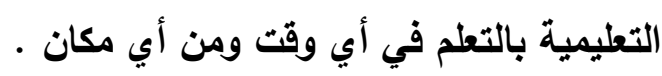
- - ضرورة أن تتضمن عمليتى التعليم والتعلم أنشطة تفاعلية ينخرط فيها الطلاب المعلمين

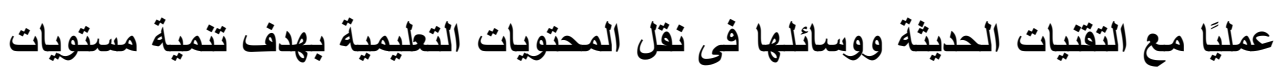
عمق المعرفة ويرفع من كفاءة جداراتهم التقويمية . - توظيف تكنولوجيا التعليم بمختلف صورها فى نشر المقررات الدراسية، وإعادة تنظيم محتواها، بما يتمشى وطبيعة عصر المعلوماتية والتكنولوجية والحصول على المعرفة، والاتصال بين الطلاب، وإتاحة فرصة التعلم الذاتى لهم، وذلك لتسهيل العملية التعليمية باعتبارها مكملاً تعليميًا وليس اثرائيًا. - توجيه اهتمام الباحثين وأعضاء هيئة التدريس ومخططي المناهج إلى تقويم التئيم النواتج التعليمية باستخدام مستويات عمث المعرفة بلالا من استخدام مستويات بلوم.

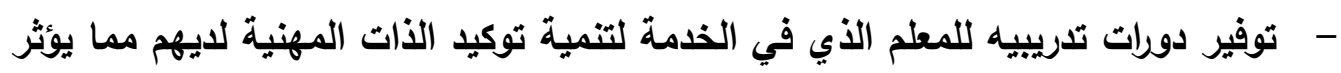

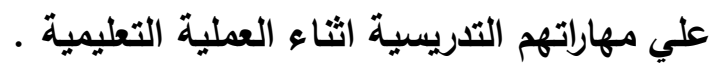
- - الاهتمام بأساليب وطرائق تثمية مستويات عمق المعرفة لاى الطلاب بالمراحل التعليمية

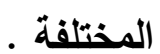




\section{المقترحات المستقبلية للبحث}

ا - فاعلية توظيف الكائنات الرقمية في تدريس مقرر التقييم التريوي لتنمية جدارات الذات

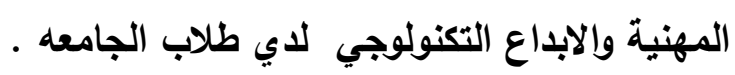

r - برنامج تدريبي قائم علي تحليل الاحتياجات المهنية والاكاديمية لتنمية الرضا المهني

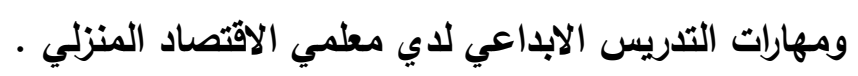

r- توظيف مراسي التعلم في تدريس مقرر طرق التدريس لتنمية الانداماج النفسي

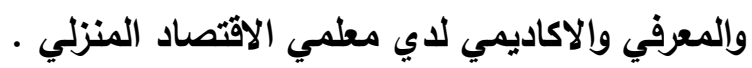
ع - تنمية مستويات عمق المعرفة لاي طلاب المرحلة الثانوية وقياس أثرها علي الأكاء

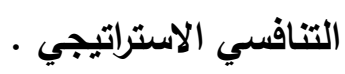




\section{المراجع}

أولا : المراجع العربية

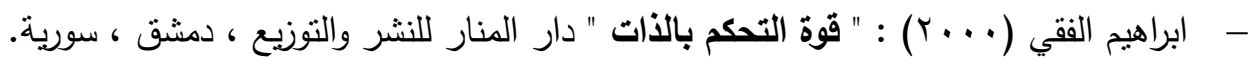

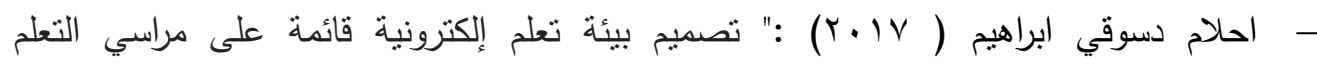
وأثرها في تتمية مهارات استخدام نظام إدارة التعلم الإكتروني (Anchored Learning)) (Desire2Learn)

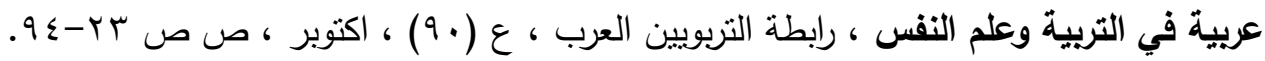

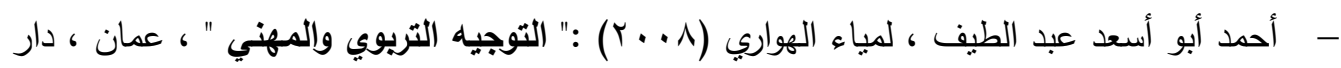

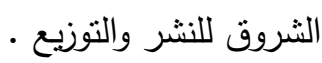

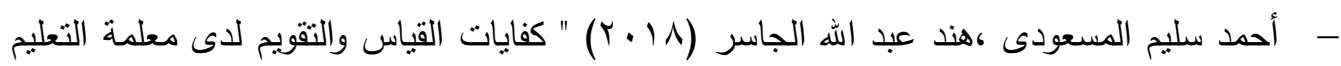

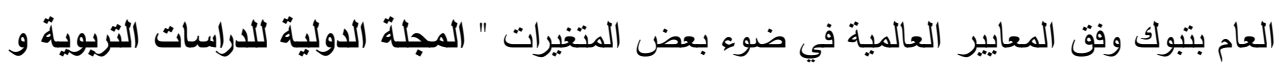

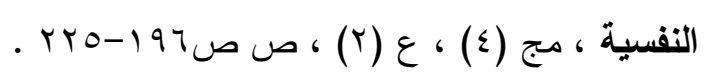

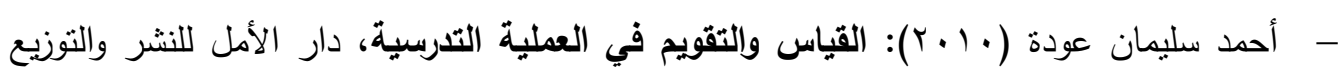

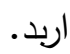

- أسامة جردات (7 (ب): " التتريب الاحترافي: جدارات ومسار" مؤثمر التدريب الأول ( الكويت

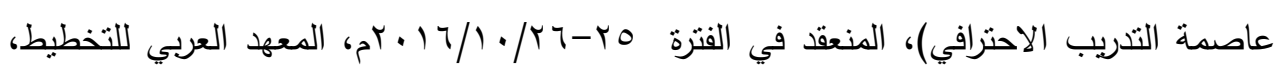

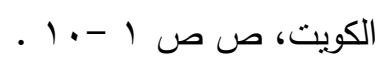

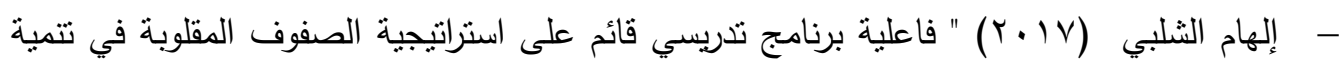

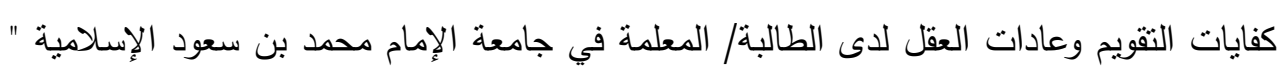

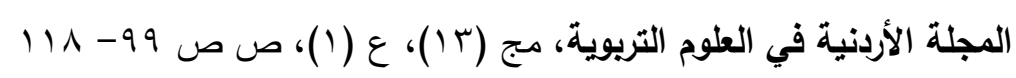

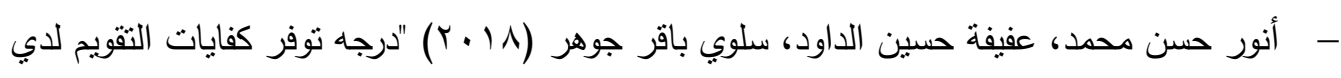

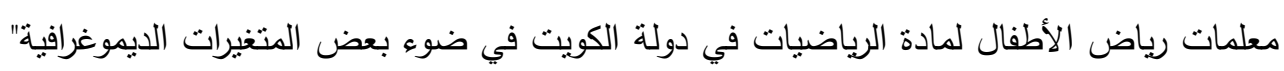

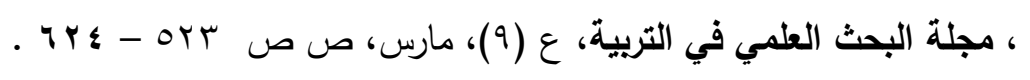

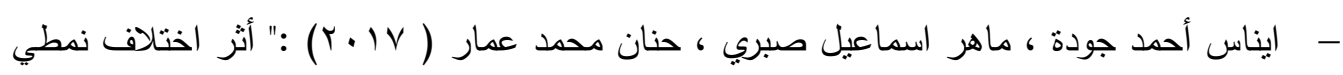

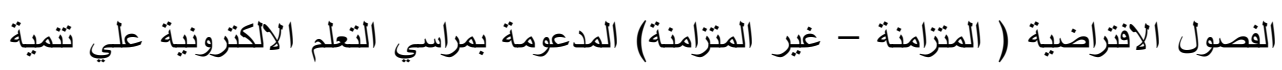

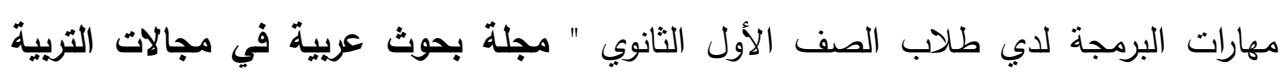

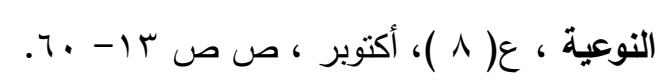




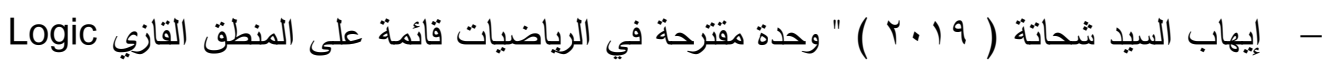

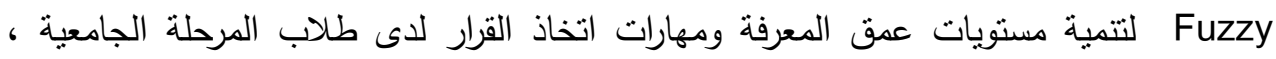

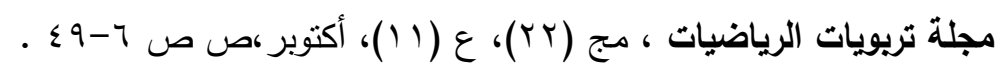

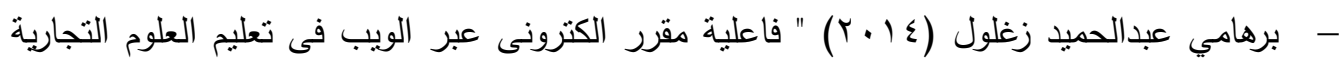
الاككتروني لتتمية المعارف وجدارات التقويم الثامل والدافعية للتعلم لدي طلاب شعبة التعليم

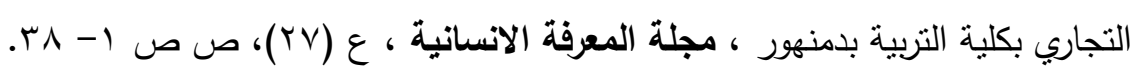

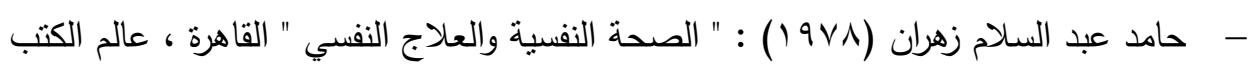

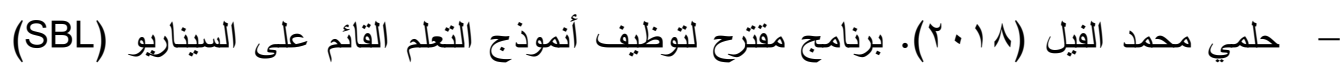
في التدريس وتأثيره في نتمية مسنويات عمق المعرفة وخفض التجول العقلي لدى طلاب كلية

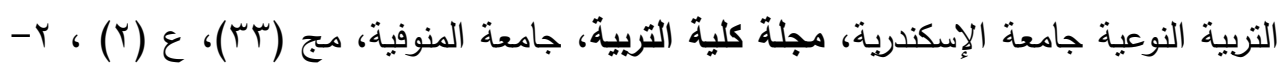
.77

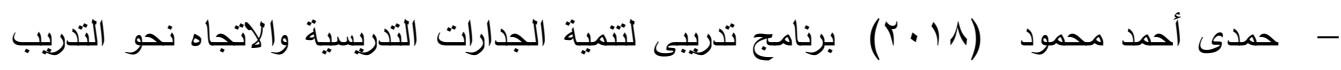
أثناء الخدمة لاى معلىى الدراسات الاجتماعية بمرحلة التعليم الأساسى فى ضوء احتى احتباجاتهم

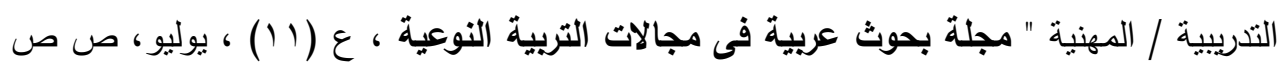
. VT-乏)

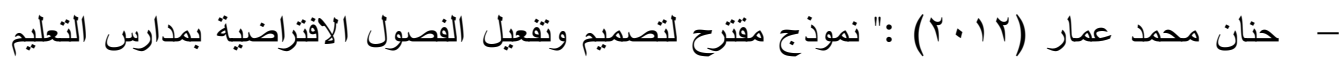

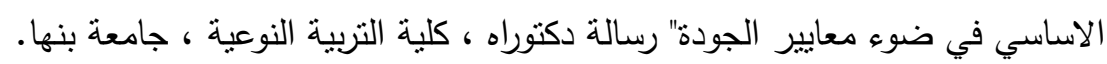

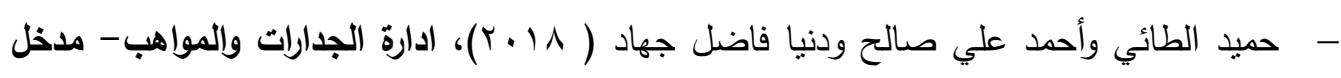
الشمولي، دار اليازوري العلمية للنشر والتوزيع.

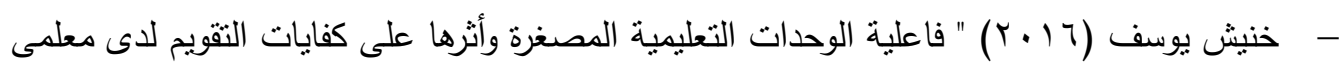

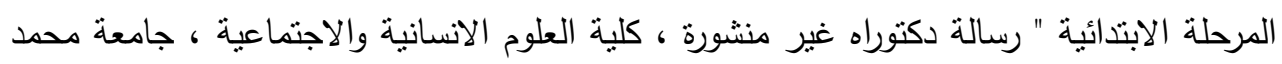

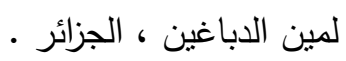

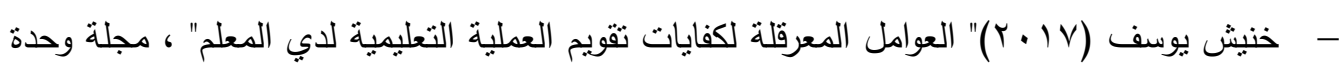

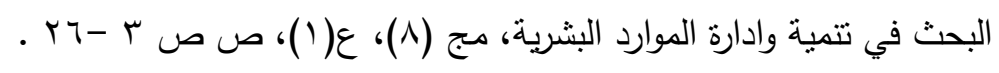

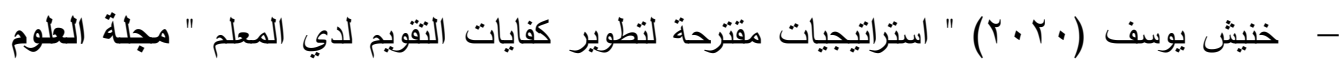

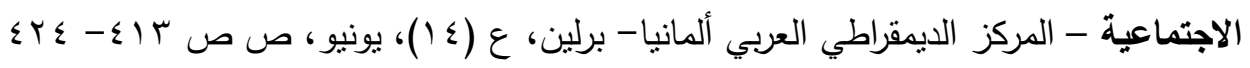

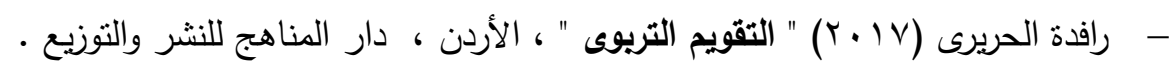


- رشدي فام (1997) : "حجم التأثير " الوجه المكمل للالالة الإحصائية ، المجلة المصرية

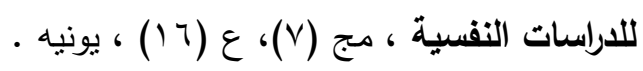

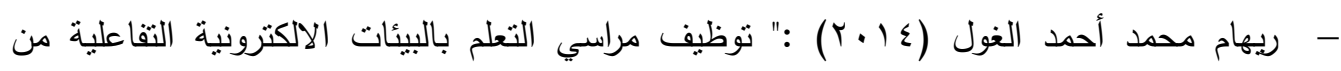
منظور جديد في ضوء تطبيقات جوجل " مجلة التعليم الالكترونية ، جامعة المنصورة ، ع (ب ال).

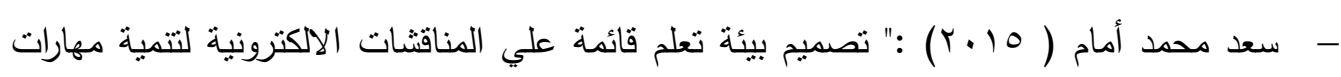

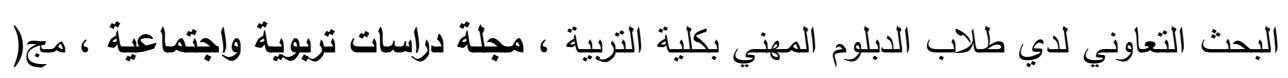

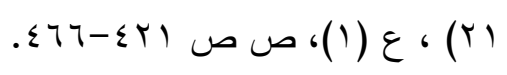

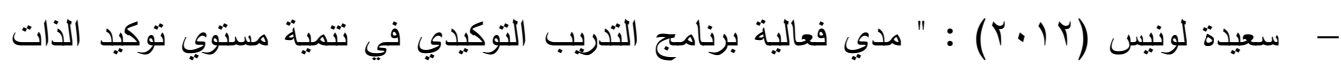

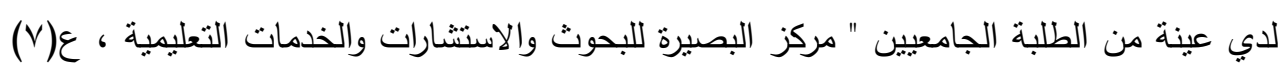

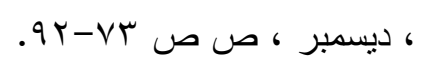

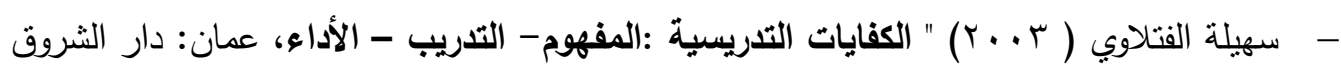

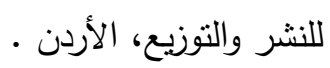
- سبد أحمد الغامدي ، فتحي مهدي نصر (19 ـ ب):" مقياس توكيد الذات لدي طلاب المرحلة

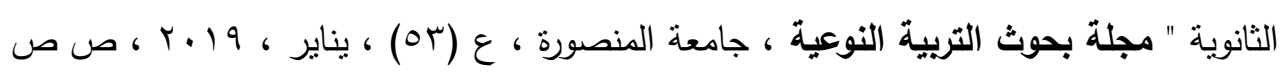
$.9-1$

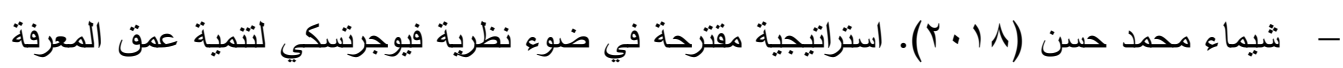

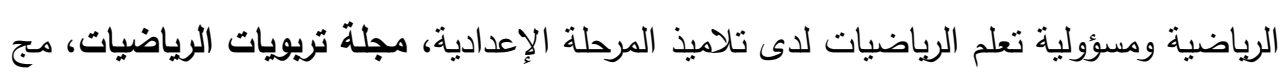

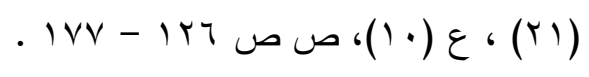

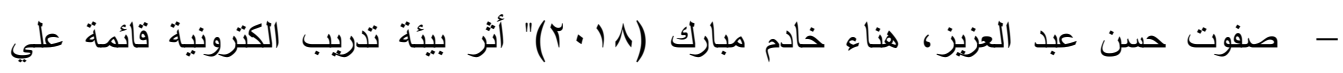

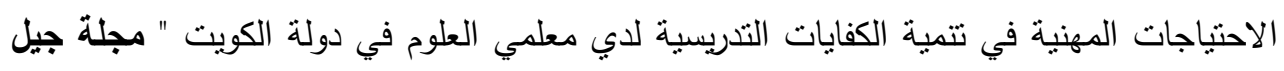

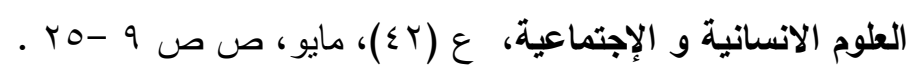

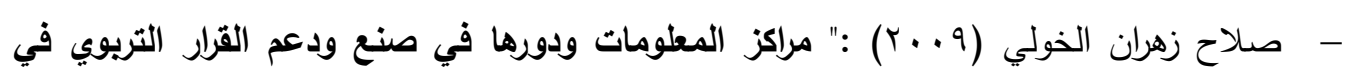

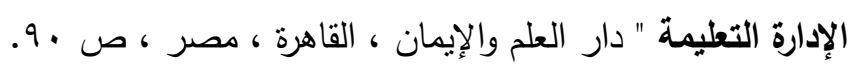

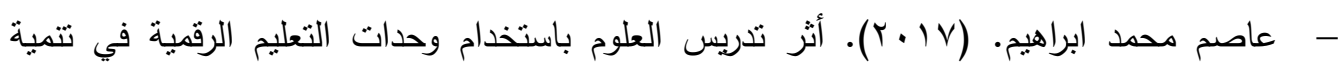

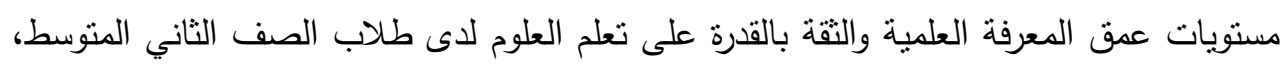

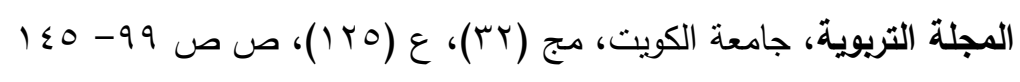




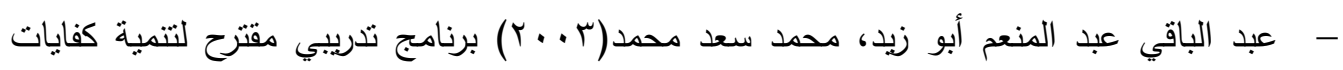

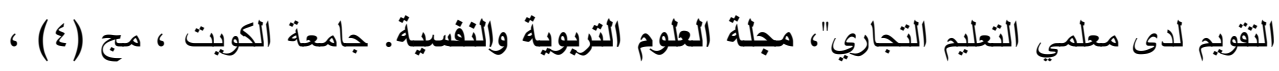

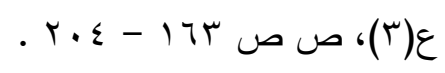

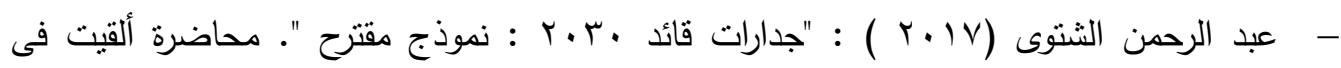

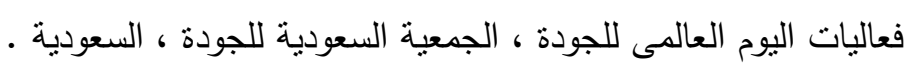

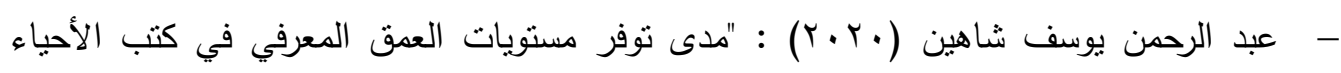
للمرحلة الثانوية نظام المقررات في المملكة العربية السعودية " دراسة تحليلية " المجلة العلمية

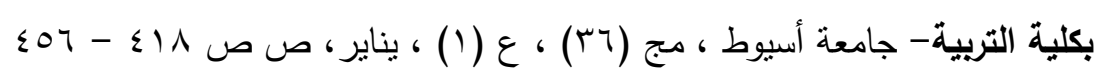

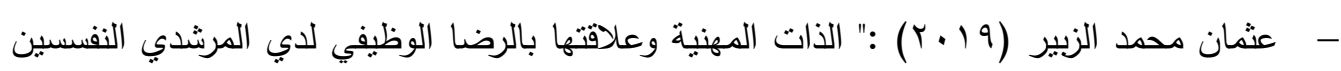
في الددارس الثانوية بولاية الخرطوم " مجلة الدراسات العليا ، جامعة النيلين ، كلية الدراسات العليا

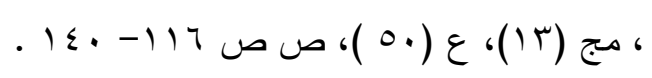

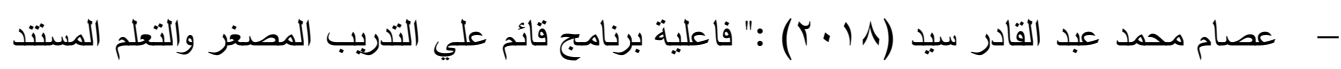
علي الدماغ في تتمية مهارات التفكير العلمي ومهارات تدريسية وتوكيد الذات المهنية لاب معلمي

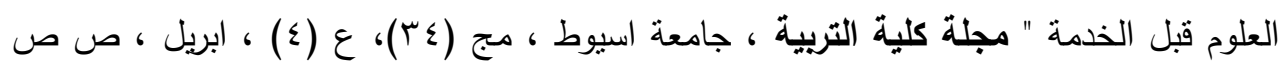
$.0 \mathrm{~V}-1$

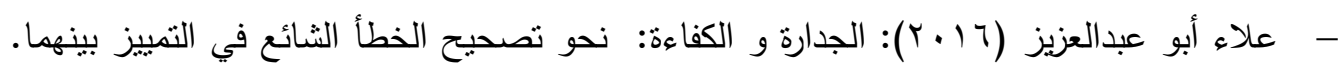

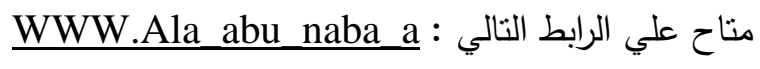

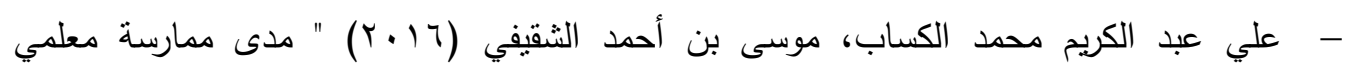
الدراسات الاجتماعية لكفايات التقويم المستمر في مدارس مدينة مكة المكرمة " مجلة دراسات

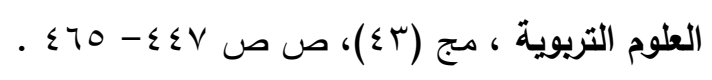

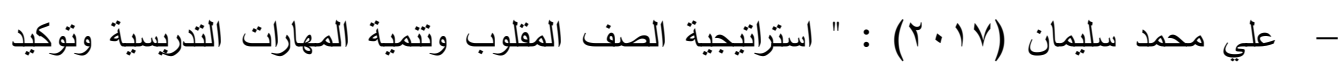

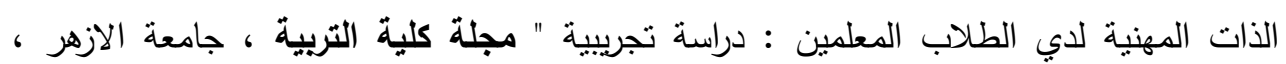

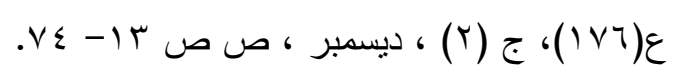

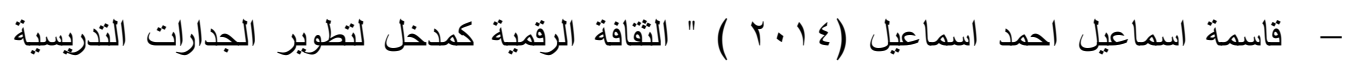
والانخراط فى التدريس لدى معلى العلوم التجارية فى ضوء النظرية الاتصالية " ، رسالة ماجستير

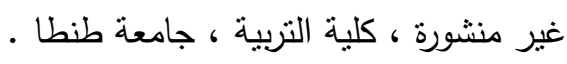
- - كمال زيتون ( 2003 ) " التدريس نماذجه ومهاراته ، القاهرة: عالم الكتب. 


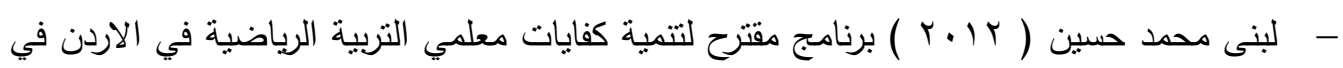

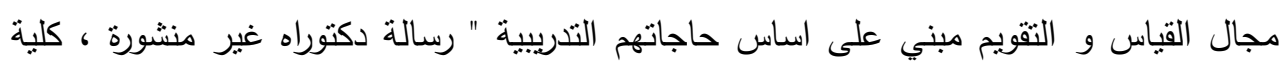

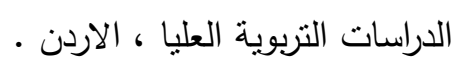

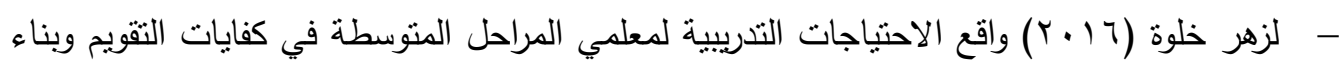

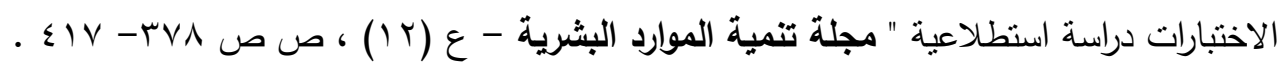

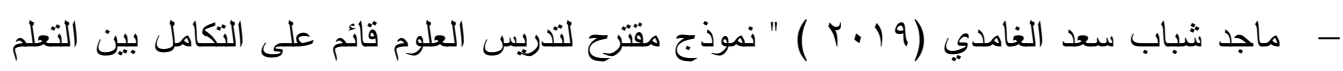
البنائي والنمذجه المفاهيمية وأثزه على عمق المعرفة العلمية لدى طلاب السادس الابتدائي بمحافظة

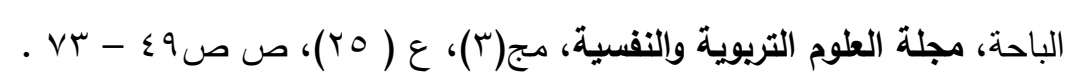

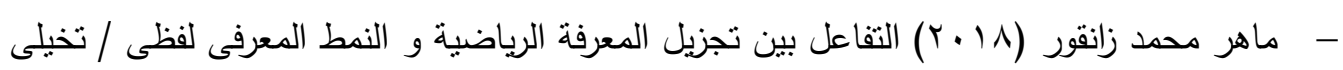
و السعة العقلية لتتمية الفهم العميق فى الرياضيات لدى طلاب الصف الأول الثانوى ، مجلة

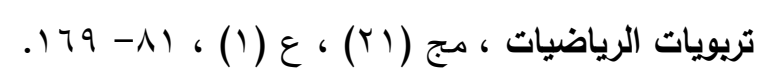

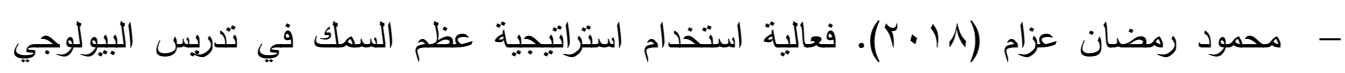
لطلاب الصف الثاني الثانوي في تتمية عمق المعرفة البيولوجية ومهارات التفكير البصري، المجلة

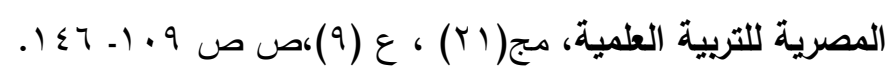

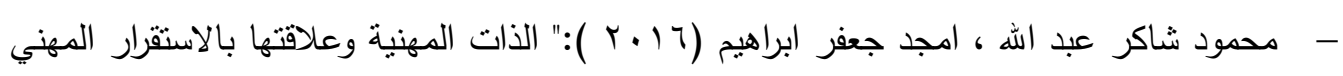

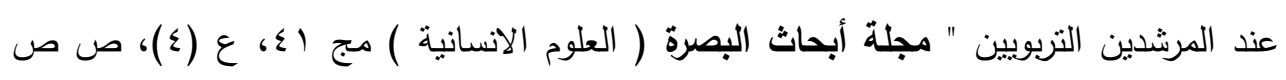

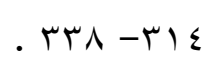

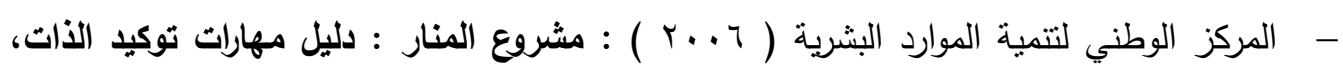
عمان : مطابع الاستور التجارية .

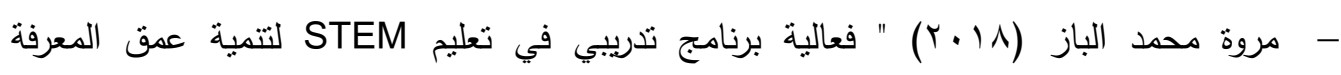

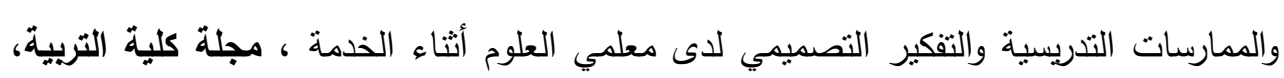

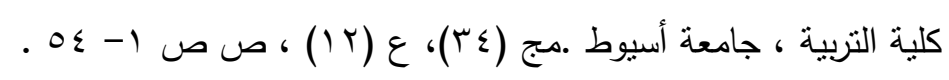

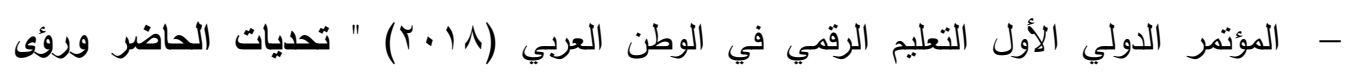

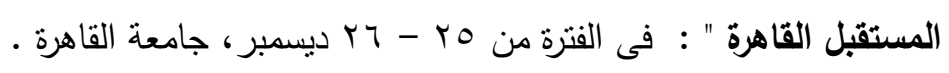
- - المؤتمر العلمي السنوي الخامس للجمعية العربية لتكنولوجيا التربية بالتعاون مع كلية التربية

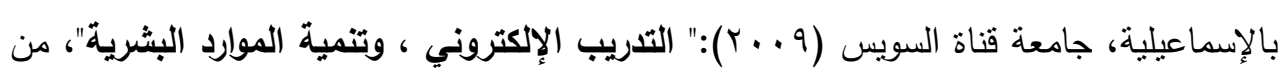

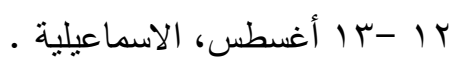




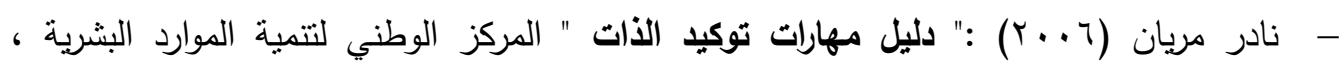

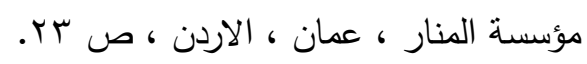

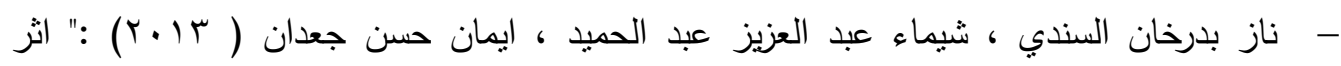
أسلوب توكيد الذات في نتمية الاحساس بالمعني الوجودي للحياة لاي طلاب الجامعة " مجلة كلية

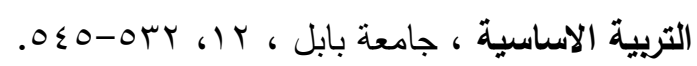

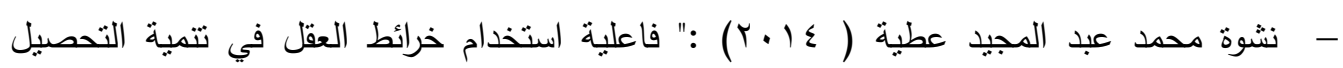
المعرفي وبعض مهارات الذكاء الوجداني لدي الطلاب الدارسين لمادة علم النفس في المرحلة

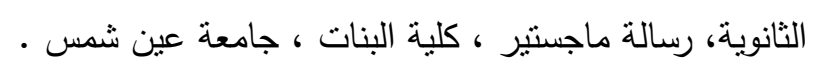

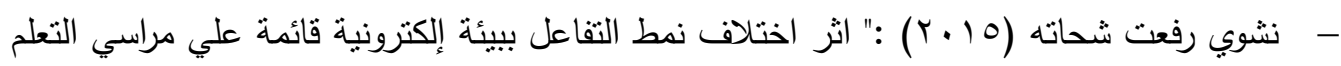
في تتمية مهارات تطوير بررجيات المحاكاة التفاعلية لدي طلاب الدبلوم المهني بكلية التربية "

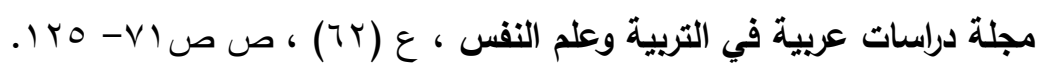

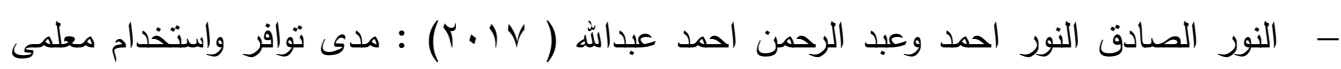
الرياضيات للكفايات التقويميه فى المدارس الثانوية بمحلية شرق النيل، مجلة العلوم التربوية، مج التر

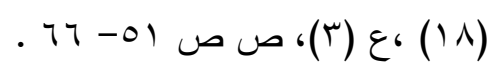

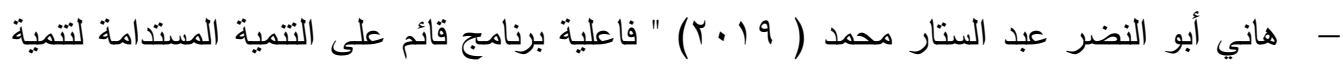

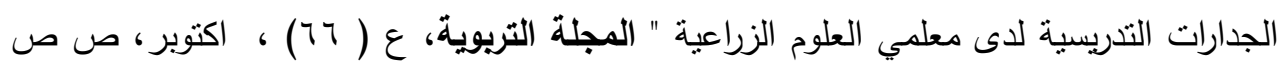
$.1111-1 \cdot v$. - - الهيئة القومية لضمان جودة التعليم والاعتماد ( با.بץ) " المعايير القومية الاكاديمية المرجعية قطاع كليات التربية ، القاهرة ، الهيئة القومية لضمان جودة التعليم والاعتماد.

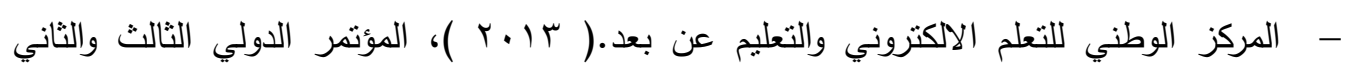

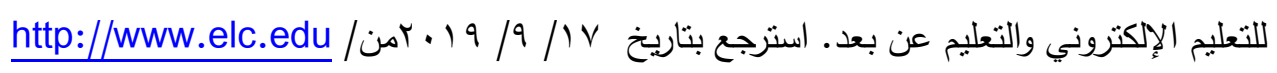

- - مليد يسري الرفاعي (19 • ب) بيئة تعلم إلكترونية تكيفية قائمة على نموذج التلمذة المعرفية لطلاب

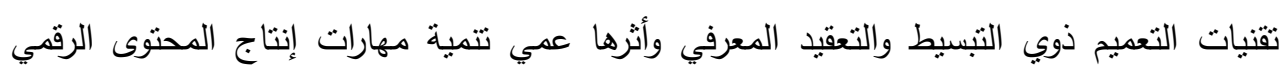

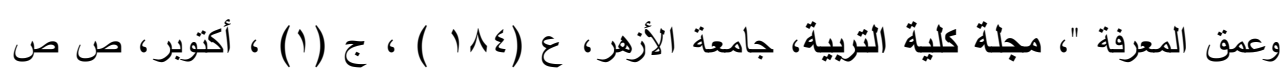
. NOV - VTO 


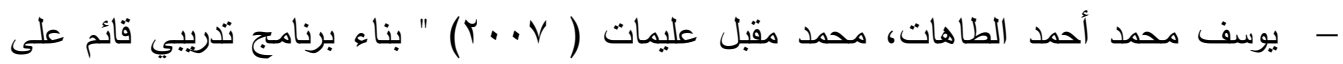
الكفايات النقويمية المعرفية والأدائية لمعلمي التربية المهنية في الأردن وبيان أثنره في تتمية نلك

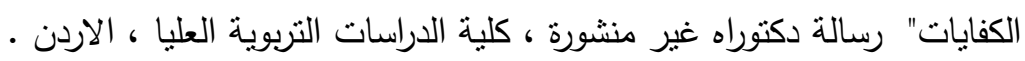

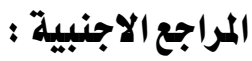

Baer, E. (2016). Leading for Educational Equity in a Context of Accountability : Instructional Technology. Methods and Depth of Knowledge. PhD Dissertation , Southern Illinois University Edwardsville.

Bounds, P. (2013) . Examining the relationship between career decision selfefficacy, ethnic ideni-ty, and academic self -concept and achievement of Africn American high school students.(Order No. 3608193, The University of lowa).Pro Quest Dissertations and Theses, 143.

Boyles, N. (2016) " Pursuing the Depths of Knowledge . Educational Leaders , $74(2)$. 46-50 .

Chapman, D.N. (2014). Using PulpMotion Videos as Instructional Anchors for Pre-Service Teachers Learning about Early Childhood Special Education International Research in Early Childhood Education ,5(1),56-63.

Filani,E.O.(2010) "Teacher education in a democratized Nigeria : challenges and way forward. Being a Lead Paper Presented at the National Conference of South-West Colleges of Education Academic Staff Union (COEASU), Ondo.

Hartento,P. \& Reye, J. ( 2013) .Incotporating Anchored Learning in a Consortia . Proceedings of the 2Ist International Conference on Conference on Computers in Education. Indonesia, Asia Pacific - Soiety For computers in Education, Nov, 18 -22 ,pp 5-8 .

Hess, K., Jones, B., Carlock, D \& Walkup, J. (2009). Cognitive Rigor: Blending the Strengths of Bloom's Taxonomy and Webb's Depth of Knowledge to Enhance Classroom-level Processes. ERIC Number: ED517804.

Hess, K., Jones, B., Carlock, D. and Walkup, j. (2009). Cognitive Rigor: Blending the Strengths of Blooms Taxonomy and Webb's Depth of Knowledge to Enhance Classroom- Level Processes. ERIC Number: ED517804. I

Holmes, S. (2011): Teacher Preparedness for Teaching and Assessing Depth of Knowledge. PhD Dissertation, University of Southern Mississippi. 
Huang, H. (2006): Breadth and Depth of English Vocabulary knowledge: Which Really Matters in the Academic Reading Performance of Chinese University Students?, Master Thesis, McGill University, Montreal.

Jackson. T.H. (2010). Teacher Depth of Knowledge as a Predictor of Student Achievement in the Middle Grades. Ph.D. dissertation. University of Southern Mississippi. Retrieved from:

https://aquila.usm.edu/cgi/viewcontent.cgi? article $=2015 \&$ context $=$ dissertations . Last visited. 17 February 2018

Khadri , Hanaa Oude (2014) " Planning For Establishing STEM Education Department Within Faculty Of Education - Ain Shamas university an Interdisciplinary Model , European Scientific Journal , 10 (28) , 280311.

Koloi, Keaikitse, S. (2016) " Assessment training a precondition for teachers' Competencies and use of classroom assessment practices. International Journal of Training and Development .Vol .20.No,2 .PP107-123 .

Landine , J. (2013) .The Relationship Between Vocational Self-Concept, Ego-Identity Development, and Vocatonal Decision- Making. The Canadian Journal of Career Development, (12) 2, 5-18.

Lera A. Kamalova Kazan (2016). Professional Self-Affirmation of a Teacher as a Functional Activity System, International Society of Educational Research, Mathematics Education, 2016, 11(1), 279-290.

Lera A.Kamalove (2016):" Professional Self- Affirmation of a Teacher as a Functional Activity System " Mathematics Eduction, 2016 , 11(1), 279290.

Matsenjwa,L.R.,(2013) " Primary School Teachers Knowledge and Skills of measurement and assessment, A case of Swaziland Problem of Education in the 21st Century, Vol.55, PP 74- 87.

Matthew,P.,Bruce., Frank,R. Steven, M., Larry, A., Michael, C., David, C. and Monica , T.,(2013) " the Science of Decision Making United States Department of Agriculture ,General Teaching Report .

Mississippi State University (2009). Webb's Depth of Knowledge Guide Career and Technical Education Definitions, $\underline{\text { HTTP:// }}$ REDESIGN.RCU.MSSTATE.EDU.

Özdemir, S, M.(2013) " Elementary Teacher Competencies and In service Training Needs and Alternative measurement and Assessment tools . Journal of Turkish Educational Sciences,3(4) .813-816 . 
Joan Herman ; Robert Linn (2014). New Assessments, Teaching Geography. University Science News , 16 (21), May . available at : http// science .uniserve . edu . au //newsletter/ vol 16 / Johnson.html.

Roe, E.( 2014). Anchored Instruction. Retrieved Dec25,2014 form http://www.multiverse.co.uk/whitepaper.pdf.

Roxanne, R. \& Kathy O Connell(2007). Anchored instruction. CAST. (online) available http://dl.cast.org/ncac/anchoredinstuction/663.cfm.

Samson k,L, (2015):" Using Strategies From Graphic Design to Improve Teaching and Learning, Essentials of Teaching and Integrating Visual and Media Literacy, pp. 3-26, Lesley University Springer International Publishing, USA.

Thomas, J. (2017). Noticing and Knowledge: Exploring Theoretical Knowledge for Teaching, the Mathematics Educator. 26 (2). 3

Webb ,N. (1997). Criteria for Alignment of Expectations and Assessm-ents on Mathematics and Science Education. Washington ,DC: Council of Chief State School Officers.

Webb ,N. (1999). Alignment of Science and Mathematics Standards and Assessments in Four States. Washington ,DC: Council of Chief State School Officers.

Yusung Heo (2007) :" The impact of multimedia anchored instruction on the motivation to learn of students with and without learning disabilities placed in inclusive middle . school language arts classes . Doctor of Philosophy, the university of Texas at Austin.

Zhang, X., Lu, X. (2015). The Relationship between Vocabulary Learning Strategies and Breadth and Depth of Vocabulary knowledge. The Modern Language Journal, 99(4), pp740-753. 